UNIVERSIDADE DE SÃO PAULO

INSTITUTO DE GEOCIÊNCIAS

\title{
QUANTIFICAÇÃO PARA A VALORAÇÃO ANTECIPADA DA CARACTERIZAÇÃO E RECUPERAÇÃO DO DANO AMBIENTAL ORIGINADO POR COMBUSTÍVEIS FÓSSEIS
}

\author{
MÁRIO DE BRITO MARCELINO
}

\author{
Tese apresentada ao Instituto de \\ Geociências da Universidade de São \\ Paulo, como parte dos requisitos para \\ obtenção do grau Doutor em Ciências. \\ Área de concentração: Recursos Minerais \\ e Hidrogeologia. \\ Orientador: Dr. Joel Barbujiani Sigolo.
}

São Paulo 


\title{
UNIVERSIDADE DE SÃO PAULO INSTITUTO DE GEOCIÊNCIAS
}

\section{QUANTIFICAÇÃO PARA A VALORAÇÃO ANTECIPADA DA CARACTERIZAÇÃO E RECUPERAÇÃO DO DANO AMBIENTAL ORIGINADO POR COMBUSTÍVEIS FÓSSEIS}

\section{MÁRIO DE BRITO MARCELINO}

Orientador: Prof. Dr. Joel Barbujiani Sígolo

Tese de Doutorado

№ 632

\author{
COMISSÃO JULGADORA \\ Dr. Joel Barbujiani Sígolo
}

Dra. Claudete Bezerra dos Santos Canada

Dra. Tatiana Luiz dos Santos Tavares

Dr. José Luiz Albuquerque Filho

Dr. Reginaldo Antonio Bertolo

SÃO PAULO 
A meu pai e irmãos que já não estão mais entre nós, mas que contribuíram para formar o que eu sou e continuarão eternamente presentes em minha memória e coração..... 


\section{AGRADECIMENTOS}

Registro meus agradecimentos a todos aqueles que colaboraram, direta ou indiretamente, para realização deste trabalho, e, principalmente àqueles que acreditaram que iria terminá-lo!

Saliento meus especiais agradecimentos:

$\checkmark$ Ao Professor Dr.Joel Barbujiani Sigolo, pela orientação e o incentivo para o desenvolvimento desta pesquisa e para seu término.

$\checkmark$ Às empresas de consultoria e distribuidoras de combustíveis que contribuíram, de forma anônima, com os dados avaliados.

$\checkmark$ Aos amigos César Garcia e Fabio L.V. de Oliveira pela cooperação e discussões sobre o tema.

$\checkmark$ Aos amigos da FREVO Ecoinovação e Sustentabilidade, que, através da compreensão e cooperação ao longo do dia a dia, proporcionaram as condições necessárias para o desenvolvimento e conclusão deste projeto de pesquisa.

$\checkmark$ Ao Instituto de Geociências da USP e o Centro de Pesquisa de Água Subterrâneas - CEPAS, pelo apoio técnico.

$\checkmark$ A minha mulher e companheira, Fabiana Gouveia Franco, que me proporcionou a coragem necessária para o desenvolvimento e conclusão deste trabalho. Sua inestimável ajuda é presente ao longo do texto, pois, durante incansáveis noites, efetuava leitura e correção, mesmo "sem entender" do que estava escrito.

$\checkmark$ Ao meu eterno mestre, Prof. Dr. Aldo Rebouças, que, apesar de não mais estar conosco nesta vida, além de me apresentar a hidrogeologia, me fez gostar de efetuar pesquisa e contribuir para o desenvolvimento da área técnica e científica. 


\section{EPÍGRAFE}

A quantidade e a qualidade da dor que sentimos são determinadas pelas nossas experiências prévias e de quão bem nos lembramos dela; pela capacidade de entender suas causas e compreender suas consequências.

(Wall Melzack) 
Marcelino, M.B. (2021) Quantificação para a valoração antecipada da caracterização e recuperação do dano ambiental originado por combustíveis fósseis. Tese de Doutorado, Instituto de Geociências - USP.

\section{RESUMO}

A tese apresenta um modelo de quantificação e valoração antecipada da investigação e remediação do dano ambiental reversível originado por combustíveis fósseis, tendo por base os dados obtidos até a Investigação Confirmatória, aqui denominada EBIC (Estimativa Baseada na Investigação Confirmatória). O modelo apresentado é resultante da quantificação e análise de 878 etapas de Gerenciamento de Áreas Contaminadas (GAC) no Estado de São Paulo, desenvolvidas por 21 empresas em 44 áreas diferentes. Os dados indicam $92,31 \%$ de chances de haver a necessidade da recuperação do dano reversível quando detectados contaminantes em concentrações acima do permitido legalmente, com o GAC ocorrendo ao longo de 6,5 anos. Foi verificada uma baixa variação dos parâmetros hidrogeológicos das áreas contaminadas, independente do contexto geológico regional e a predominância da tecnologia de remediação da Extração Multifásica (MPE), seguida pelo Pump \& Treat (P\&T) e da Extração de Vapores (SVE) com ventilação induzida - Air Sparging (ASp). O modelo EBIC estima as atividades e prazos médios necessários para a investigação e remediação do dano reversível, subsidiando a cotação das mesmas no mercado, de forma a possibilitar sua valoração antecipada. Considerando que a contaminação impacta o uso do imóvel e dos Serviços Ambientais, estes devem valorados, para uma possível reparação.

PALAVRAS-CHAVE: Áreas contaminadas. Hidrogeologia ambiental. Dano ambiental. Quantificação de investigação. Quantificação da remediação. Valoração de dano ambiental. 
Marcelino, M.B. (2021) - Quantificação para a valoração antecipada da caracterização e recuperação do dano ambiental originado por combustíveis fósseis. Tese de Doutorado, Instituto de Geociências - USP.

\begin{abstract}
The thesis presents a model of quantification and early assessment of the investigation and remediation of reversible environmental damage originated by fossil fuels, based on the data obtained at the Confirmatory Research, called EBIC (Estimation Based on Confirmatory Research). The model presented is the result of the quantification and analysis of 878 stages of Contaminated Areas Management (GAC) in the State of São Paulo, developed by 21 companies in 44 different areas. The data indicates 92,31\% chance of recovering reversible damage when contaminants are detected at concentrations above legally permitted, with GAC occurring over 6,5 years. A low variation in the hydrogeological parameters of contaminated areas was verified, regardless of the regional geological context and the predominance of Multiphase Extraction (MPE) remediation technology, followed by Pump \& Treat (P\&T) and Vapor Extraction (ES) with induced ventilation - Air Sparging (ASp). The EBIC model estimates the activities and average deadlines necessary for the investigation and remediation of reversible damage, supporting the quotation of them in the market, in order to enable their early value. Considering that contamination impacts the use of the property and environmental services, these should be valued for possible repair.
\end{abstract}

KEYWORDS: Contaminated areas. Environmental hydrogeology. Environmental damage. Quantification of research. Quantification of remediation. Environmental damage assessment. 


\section{SUMÁRIO}

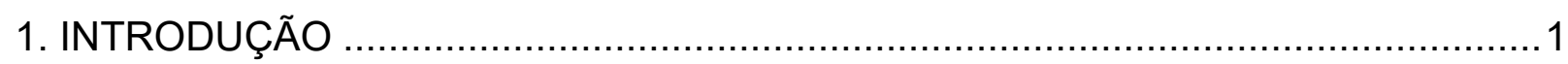

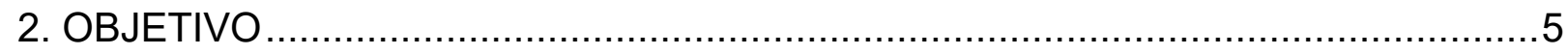

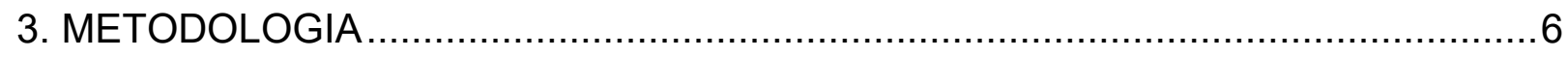

4. A VALORAÇÃO DO DANO AMBIENTAL SOB A ÓTICA DO GERENCIAMENTO DE ÁREAS CONTAMINADAS ...........................................10

4.1 CONTEXTO LEGAL DO GERENCIAMENTO DE ÁREAS CONTAMINADAS E DO

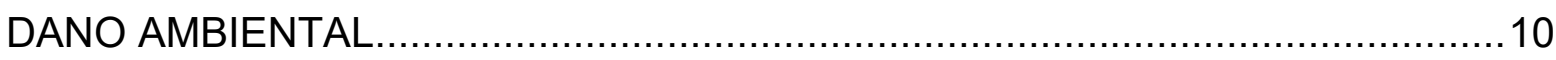

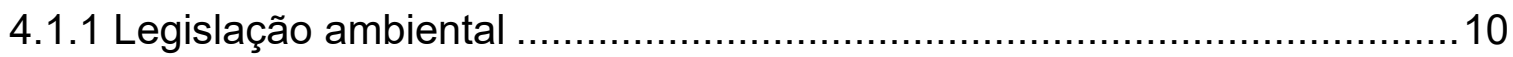

4.1.2 Aspectos da legislação do dano ambiental .........................................14

4.1.3 Reparação do dano ambiental associado as áreas contaminadas no

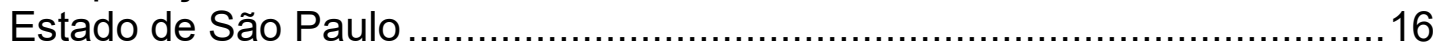

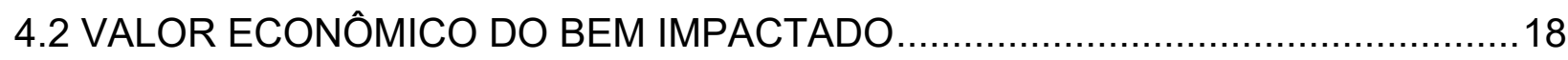

4.2.1 Valoração econômica do imóvel impactado .............................................19

4.2.2 Valoração econômica dos serviços ambientais ou ecossistêmicos ............21

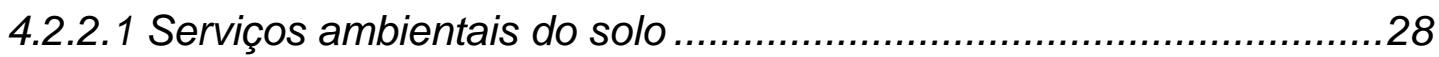

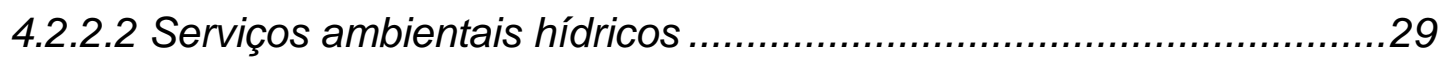

4.2.2.3 Serviços culturais ou socioculturais ............................................... 30

4.3 INVESTIGAÇÃO DO DANO AMBIENTAL - ÁREA CONTAMINADA ......................31

4.4 O IMPACTO AMBIENTAL - A OCORRÊNCIA DA CONTAMINAÇÃO POR

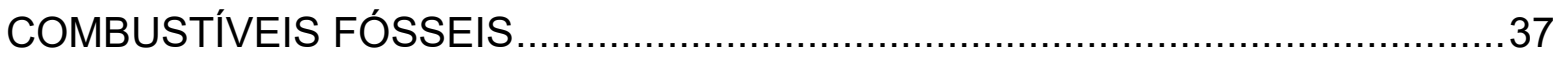

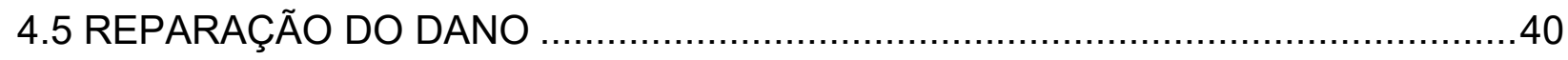

4.5.1 Reparação do dano ambiental reversível - Remediação ambiental ..........42

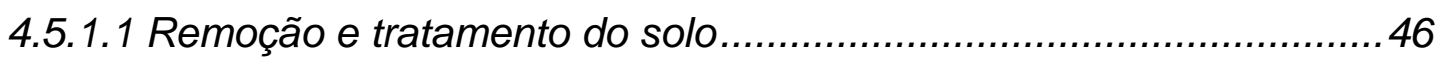

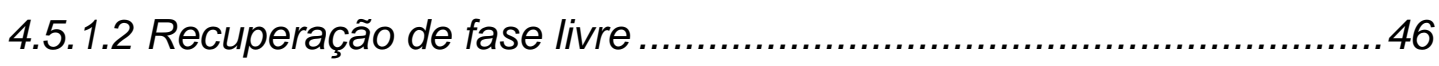

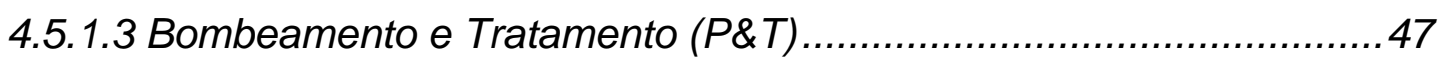

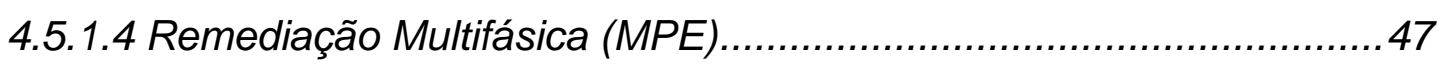

4.5.1.5 Soil Vapor Extraction (SVE) e Air Sparging (ASp) ..........................48

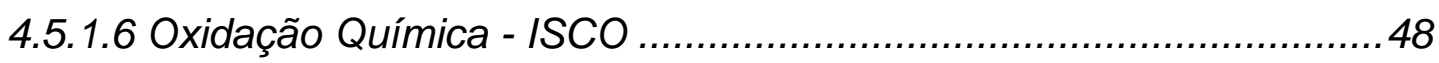

4.5.1.8 Atenuação Natural Monitorada (ANM) .........................................49 
4.5.1.9 Custos médios associados ao gerenciamento de área contaminada......

4.5.2 Compensação do dano ambiental irreversível

5. ANÁLISE DE DADOS DO GERENCIAMENTO DE ÁREAS CONTAMINADAS NA VALORAÇÃO DO DANO AMBIENTAL ........................................................58

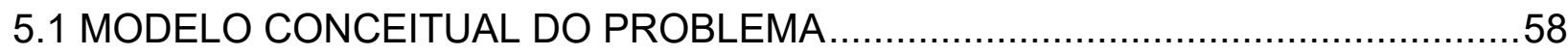

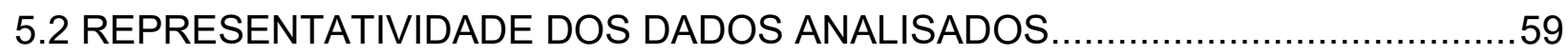

5.3 CARACTERÍSTICAS DAS AÇÕES DE GERENCIAMENTO DE ÁREA CONTAMINADA - GAC 68

5.4 QUANTITATIVOS DAS AÇÕES DE INVESTIGAÇÃO DO DANO REVERSÍVEL 72

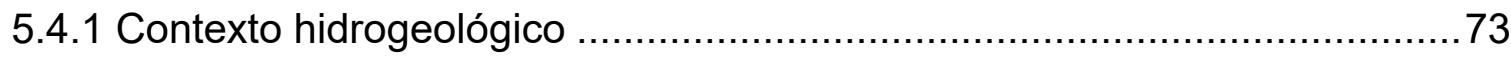

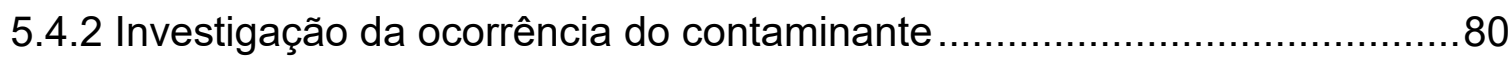

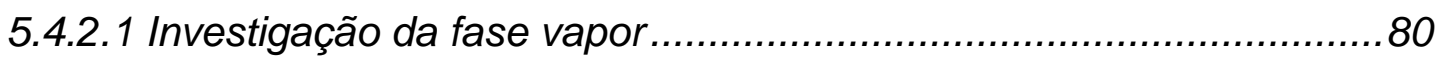

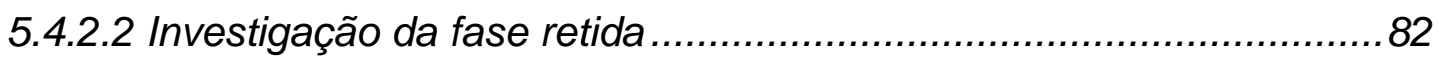

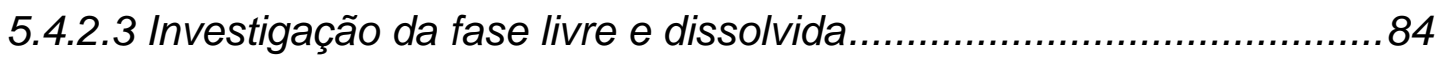

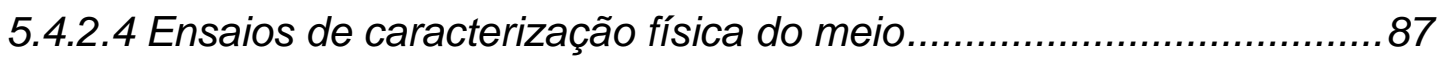

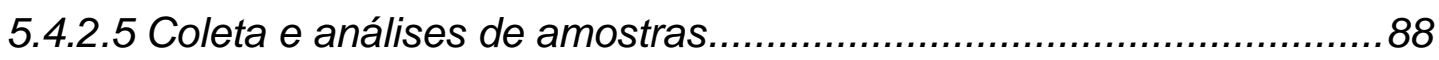

5.4.3 Das características da ocorrência do contaminante...................................91

5.4.3.1 Características da ocorrência da fase retida................................... 94

5.4.3.2 Características da ocorrência da fase vapor....................................94

5.4.3.3 Características da ocorrência da fase livre ......................................96

5.4.3.4 Características da ocorrência da fase dissolvida............................97

5.5 Análise dos prazos envolvidos na reparação do dano reversível ............................98

5.5.1 Prazos para a reparação da fonte da contaminação e da fase retida ......102

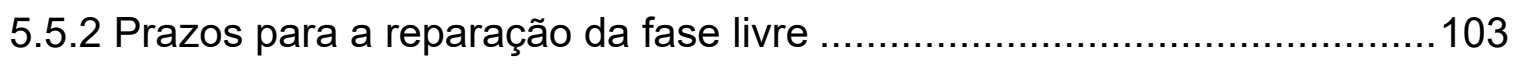

5.5.3 Prazos para a reparação da fase livre e vapor .....................................105

5.5.4 Prazos para a reparação da fase dissolvida e vapor ..............................106

5.5.5 Prazos para a reparação da fase dissolvida ........................................107

5.5.6 Conclusões preliminares sobre os sistemas de remediação do dano reversível implantado.

6. PROPOSTA PARA A QUANTIFICAÇÃO PARA A VALORAÇÃO DO DANO AMBIENTAL REVERSÍVEL 
6.1 PROPOSTA DA QUANTIFICAÇÃO PARA A VALORAÇÃO DAS ATIVIDADES DE INVESTIGAÇÃO DA ÁREA CONTAMINADA

6.1.1 Calibração e validação da quantificação das atividades de investigação.

6.2 PROPOSTA DE QUANTIFICAÇÃO PARA A VALORAÇÃO DAS ATIVIDADES DE RECUPERAÇÃO DO DANO REVERSÍVEL

6.2.1 Situação de não necessidade de remediação do dano reversível 121

6.2.2 Situação de necessidade remediação do dano reversível 121

6.2.2.1 Remediação da fonte e fase retida, sem ocorrência de demais fases de contaminantes 123

6.2.2.2 Remediação da fase livre 124

6.2.2.2.1 Fase livre de diesel (combustível pesado) em pequena extensão $\left(<45,0 \mathrm{~m}^{2}\right)$.

6.2.2.2.2 Fase livre de combustíveis em grande extensão $\left(>45,0 \mathrm{~m}^{2}\right)$ ................................................................................. 125

6.2.2.3 Remediação da dissolvida com risco da fase vapor. ....................127

6.2.2.3 Remediação da fase dissolvida sem risco na fase vapor. ...............128

6.2.3 Calibração e validação da quantificação das atividades de remediação

7. CONTRIBUIÇÃO PARA A REPARAÇÃO DO DANO AMBIENTAL IRREVERSÍVEL

7.1 O IMPACTO DO DANO AMBIENTAL NO IMÓVEL

7.2 O IMPACTO DO DANO AMBIENTAL NOS SERVIÇOS AMBIENTAIS CULTURAIS

7.3 O IMPACTO DO DANO AMBIENTAL NOS SERVIÇOS AMBIENTAIS DO SOLO137

7.4 O IMPACTO DO DANO AMBIENTAL NOS SERVIÇOS AMBIENTAIS HÍDRICOS

8. CONCLUSÃO E RECOMENDAÇÃO

8.1 LIMITAÇÕES DA METODOLOGIA PROPOSTA

9. BIBLIOGRAFIA

10. ANEXOS. 


\section{LISTA DE TABELAS}

Tabela 4.1 - Principais metodologias de valoração de serviços ambientais existentes na literatura organizadas avaliadas pelo autor dessa tese.

Tabela 4.2a - Prazos das etapas de gerenciamento de área contaminada (adaptado pelo autor de IPT, 2018).

Tabela 4.2b - Prazos das etapas de gerenciamento de área contaminada (MARCELINO, 2016)

Tabela 4.3 - Análise das principais tecnologias de remediação aplicadas no Estado de São Paulo até dezembro de 2018 (elaborado pelo autor). .44

Tabela4.4 - Valores médios de mercado para as etapas de Gerenciamento de Áreas Contaminadas (IPT, 2018) 50

Tabela 5.1 - Prazos envolvidos no Gerenciamento de Área Contaminada (em meses) a partir do relatório da etapa anterior.

Tabela 5.2 - Principais características hidrogeológicas médias das áreas investigadas.

Tabela 5.3 - Principais composições litológicas verificadas nas áreas. 76

Tabela 5.4 - Quantitativos de investigação, ensaios, sondagens e instalação de poços, consolidados por área investigada avaliadas nesta tese.

Tabela 5.5 - Quantitativos médios da ocorrência da fase vapor nas áreas analisadas.

Tabela 5.6 - Prazos envolvidos no Gerenciamento de Área Contaminada (em meses) a partir do relatório da etapa anterior.

Tabela 5.7 - Análise simples dos principais dispositivos dos sistemas de remediação da zona saturada. 


\section{LISTA DE QUADROS}

Quadro 4.1 - Áreas contaminadas cadastradas no Estado de São Paulo (CETESB, 2019)

Quadro 6.1 - Dados básicos considerados para a quantificação na planilha EBIC (saída da planilha EBIC)

Quadro 6.2 - Resultados da quantificação da planilha EBIC para a investigação do dano ambiental

Quadro 6.3 - Valoração da quantificação da planilha EBIC para a investigação do dano ambiental.

Quadro 6.4 - Investimento estimado para a remediação do dano reversível, conforme planilha EBIC 


\section{LISTA DE FIGURAS}

Figura 2.1 - Incidência de riscos ao longo do desenvolvimento de um empreendimento imobiliário (MARKER, 2013).

Figura 3.1 - Fluxograma de desenvolvimento da pesquisa desenvolvida.

Figura 4.1 - Tríplice responsabilização ambiental atribuída pela legislação brasileira, organizada pelo autor.

Figura 4.2 - Fluxograma de atividades no gerenciamento de áreas contaminadas (CETESB, 2016)

Figura 4.3 - Principais elementos da ocorrência de área contaminada por combustíveis no subsolo (ilustração do autor)

Figura 4.4 - Comportamento genérico das concentrações de contaminantes na água subterrânea antes, durante e após a execução de medidas de remediação (BERTOLO et al., 2019)

Figura 4.5 - Técnicas de remediação aplicadas no Estado de São Paulo até Dezembro 2018 (CETESB, 2019).

Figura 5.1 - Proposta da Estrutura Analítica de Valoração (EAV) do dano ambiental associado a áreas contaminadas proposta pelo autor dessa tese.

Figura 5.2 - Fluxograma das etapas de investigação do dano ambiental e reparação dos danos reversíveis proposta pelo autor dessa tese. 60

Figura 5.3 - Mapa de localização das áreas contaminadas avaliadas. 62

Figura 5.4 - llustração do autor da variação da área de ocorrência do contaminante em função do procedimento de delimitação e desenho da mesma.

Figura 5.5 - Variação da largura da fase dissolvida em função da geometria da fonte e o vetor do fluxo principal da água subterrânea.

Figura6.1 - Proposta de fluxograma de quantificação de atividades de investigação da contaminação. 
Figura 6.2 - Proposta de fluxograma de quantificação de atividades de recuperação do dano reversível.

Figura 6.3 - Sequência de fluxo de decisão para a situação de não existência de risco (destacado em vermelho).

Figura 6.4 - Sequência de fluxo de decisão para a situação de apenas a ocorrência de fonte ativa e fase retida de contaminante no solo (destacado em vermelho).

Figura 6.5 - Sequência de fluxo de remediação com ocorrência defase livre de diesel (combustível pouco volátil) em pequena extensão $\left(<45,0 \mathrm{~m}^{2}\right)$ (destacado em vermelho)

Figura 6.6 - Sequência de fluxo de remediação com ocorrência de fase livre em grande extensão $\left(>45,0 \mathrm{~m}^{2}\right)$ (destacado em vermelho).

Figura 6.7 - Sequência de fluxo de remediação com ocorrência da fase dissolvida com risco da fase vapor (destacado em vermelho).

Figura 6.8 - Sequência de fluxo de remediação com a ocorrência da fase dissolvida sem risco da fase vapor (destacado em vermelho).

Figura 7.1 - llustração das áreas impactadas pelo contaminantes (SA = Serviço Ambiental). 


\section{LISTA DE GRÁFICOS}

Gráfico 5.1 - Representatividade do percentual das empresas de consultoria que elaboraram os relatórios de gerenciamento ambiental $(\mathrm{NI}=$ Não identificado).

Gráfico 5.2 - Representatividade do percentual das Bandeiras revendedoras de combustíveis.

Gráfico 5.3 - Histograma da variação da data (ano) de instalação dos postos de serviços avaliados.

Gráfico 5.4 - Histograma do tempo (anos) para o início da primeira atividade de Gerenciamento de Área Contaminada (GAC) após a instalação do posto.

Gráfico 5.5 - Representatividade do número de documentos (relatórios) associados as etapas de Gerenciamento de Área Contaminada (GAC).

Gráfico 5.6 - Histograma de análise do tempo para início da realização da Investigação Detalhada (ID) após a Investigação Confirmatória (IC).

Gráfico 5.7 - Histograma de análise do tempo total para o término do Gerenciamento de Áreas Contaminadas (GAC) a partir Investigação Confirmatória (IC).

Gráfico 5.8 - Histograma da variação da espessura da zona não saturada ou profundidade do nível de água.

Gráfico 5.9 - Histograma da variação do gradiente hidráulico da superfície freática da água subterrânea nas áreas avaliadas.

Gráfico 5.10 - Histograma da variação da porosidade efetiva nas áreas avaliadas.

Gráfico 5.11 - Histograma da variação da condutividade hidráulica obtidas em ensaios in situ.

Gráfico 5.12 - Histograma da variação da condutividade hidráulica obtidas em ensaios in situ.

Gráfico 5.13 - Correlação entre a condutividade hidráulica e o gradiente hidráulico das áreas avaliadas. 
Gráfico 5.14 - Histograma da variação da velocidade aparente (Vap) da água subterrânea.

Gráfico 5.15 - Histograma do número de sondagem executada por área avaliada nessa tese.

Gráfico 5.16 - Histograma do número de poços rasos (PMR)instalados por área avaliada nessa tese.

Gráfico 5.17 - Histograma de profundidade dos poços de monitoramento rasos (PMR).

Gráfico 5.18 - Correlação da profundidade dos poços rasos (PMR) e multiníveis (PMN) com a profundidade do nível de água nas áreas avaliada nessa tese. .86

Gráfico 5.19 - Histograma de quantidade de poços de monitoramento multiníveis (PMN) instalados por área avaliada nessa tese.

Gráfico 5.20 - Histograma de quantidade de ensaios de condutividade hidráulica realizados por área investigada.

Gráfico 5.21 - Histograma do número de coleta de amostra de solo por área investigada.

Gráfico 5.22 - Correlação do número de amostras de solo com o número de poços instalados na área.

Gráfico 5.23 - Histograma do número de coleta de amostra de água por área investigada.

Gráfico 5.24 - Histogramado número de análises químicas do parâmetro Benzeno, Tolueno, Etilbenzeno e Xilenos (BTEX).

Gráfico 5.25 - Histogramado número de análises químicas do parâmetro Hidrocarboneto Poliaromático (PAH).

Gráfico 5.26 - Correlação entre as larguras da ocorrência das fases vapor e dissolvida.

Gráfico 5.27 - Histograma do comprimento médio da fase livre de combustíveis no subsolo, por área analisada nessa tese. .96

Gráfico 5.28 - Histograma da largura média da fase livre de combustíveis no subsolo, por área analisada nessa tese. 
Gráfico 5.29 - Histograma da espessura média aparente de fase livre de combustíveis no subsolo, por área analisada nessa tese.

Gráfico 5.30 - Histograma do comprimento médio da fase dissolvida de combustíveis no subsolo, por área analisada nessa tese.

Gráfico 5.31 - Histograma da largura média da fase dissolvida de combustíveis no subsolo, por área analisada nessa tese.

Gráfico 5.32 - Histograma da espessura média da fase dissolvida de combustíveis no subsolo, por área analisada nessa tese. 98

Gráfico 5.33 - Histograma dos prazos de remediação (REM) sem considerar a remoção da fonte. 100

Gráfico 5.34 - Ocorrência das tecnologias de remediação aplicadas. 101

Gráfico 5.35 - Histograma dos prazos de remediação (REM) da fase livre pelas diversas técnicas observadas.

Gráfico 5.36- Histograma da tempo de aplicação da técnica da extração multifásica (MPE), por área investigada.

Gráfico 5.37- Histograma do tempo de aplicação da técnica da extração multifásica (MPE), por área investigada.

Gráfico 5.38 - Histograma do prazo de aplicação da Oxidação Química (ISCO), por área investigada. 109

Gráfico 5.39 - Histograma do prazo de monitoramento para o encerramento ou Atenuação Natural Monitorada (ANM), por área investigada. 109

Gráfico 7.1 - Evolução do valor do imóvel frente à caracterização da contaminação do solo e/ou da água subterrânea. 


\section{LISTA DE ABREVIATURAS E SIGLAS}

ABNT - Associação Brasileira de Normas Técnicas

ACI - Área Contaminada sob Investigação

ACRu - Área Contaminada em processo de reutilização

ANA - Agência Nacional de Águas

ANM - Sistema de remediação pela Atenuação Natural Monitorada

AvP - Avaliação Preliminar

AR - Área Reabilitada para o Uso Declarado

ASp - Sistema de remediação Air Sparging

ARtx - Análise de risco toxicológico

BTEX - Benzeno, Tolueno, Etilbenzeno e Xileno

CETESB - Companhia Ambiental do Estado de São Paulo

CF - Constituição da República Federativa do Brasil de 1988

CMA - Máxima concentração aceitável

CONAMA - Conselho Nacional do Meio Ambiente

EBIC - Estimativa baseada na Investigação Confirmatória

IC - Investigação confirmatória

ID - Investigação detalhada

INCC - Índice Nacional de Custo na Construção

ISCO - Oxidação química in situ

IPT - Instituto de Pesquisas Tecnológicas do Estado de São Paulo

ME - Monitoramento para Encerramento

MP-SP - Ministério Público do Estado de São Paulo

MPE - Sistema de remediação de Extração Multifásica

MCDM - Método comparativo dos dados do mercado 
MCA 1 - Modelo Conceitual inicial da área

NBR - Norma Brasileira

P\&T - Sistema de remediação do Bombeamento e Tratamento (Pump\&Treat)

PGJSP - Procuradoria-Geral de Justiça do Estado de São Paulo

PI - Plano de Intervenção

PNMA - Política Nacional do Meio Ambiente

RPPN - Reserva Particular do Patrimônio Natural

REM - Remediação ambiental de solo e água subterrânea contaminada

SACS - Sistema de armazenagem de combustível subterrâneo

SGS - Investigação de compostos orgânicos voláteis no solo (Soil Gas Survey)

SISNAMA - Sistema Nacional do Meio Ambiente

SQI - Substâncias químicas de interesse

SVE - Extração de vapor do solo

TAC - Termo de Ajuste de Conduta

USEPA - United States Environmental Protection Agency

USP - Universidade de São Paulo

VCP - Valor da Compensação Ambiental

VE - Valor de Existência do bem ambiental.

VERA - Valor Econômico do Recurso Ambiental

VI - Valor de intervenção de áreas contaminadas

VO - Valor de Opção do bem ambiental

VUD - Valor de Uso Direto do bem ambiental

VUI - Valor de Uso Indireto do bem ambiental 


\section{INTRODUÇ̃̃O}

Praticamente todas as atividades humanas apresentam impacto negativo nos ecossistemas, gerando substâncias, resíduos e efluentes com potencial de se tornarem fontes de contaminação nos diferentes compartimentos do meio ambiente (ar, água e solo e a rocha).Vazamentos em dutos e tanques de combustíveis, falhas em processos industriais, problemas no tratamento de efluentes, atividades de mineração, disposição inadequada de resíduos, uso de defensivos agrícolas e acidentes de transporte de substâncias químicas são as principais fontes de contaminação do solo e das águas subterrâneas (POMPÉIA, 1996).

Os compostos orgânicos aromáticos, hidrocarbonetos, metais, não metais, microorganismos e radionucleicos são os principais contaminantes do solo e das águas subterrâneas nos centros urbanos (FETTER, 1993). A ocorrência destes contaminantes no subsolo apresenta características distintas, sendo sua investigação, o controle e a remediação, atividades complexas e em contínuo desenvolvimento.

Área contaminada é definida pela CETESB (CETESB, 2018b).como sendo uma "área, local ou terreno onde há comprovadamente poluição ou contaminação, causados pela introdução de quaisquer substâncias ou resíduos que nela tenham sido depositados, acumulados, armazenados, enterrados ou infiltrados, de forma planejada, acidental ou até mesmo natural".

A ocorrência de áreas contaminadas - solo e água subterrânea - é um grave dano ambiental e à sociedade, podendo levar à desvalorização de empresas e imóveis e oferecer riscos à saúde pública, além de onerar e até mesmo alterar projetos de obras públicas.

Os terrenos contaminados com limitações de uso e com necessidade do gerenciamento da contaminação em região urbanas são conhecidos como Brownfields (termo de origem americana, inicialmente aplicado para áreas contaminadas industriais e comerciais).Cabe destacar que a revitalização ou recuperação dos Brownfields, com a sua reutilização pela sociedade, representa uma nova área verde (Greenfields) que se está conservando, sendo, assim, uma atitude para a preservação do meio ambiente. 
Os vazamentos de combustíveis são um dos grandes problemas de contaminação de solo e água subterrânea, sendo frequentemente encontrados nos centros urbanos, mas não se limitando a estes, ocasionando diversas áreas contaminadas. No ano de 2000 o Estado de São Paulo foi pioneiro ao criar um cadastro de áreas contaminadas de forma a melhor gerenciar o problema. No mesmo ano, o CONAMA emitiu a Resolução 273/2000 definindo a obrigatoriedade do licenciamento ambiental dos postos de combustíveis, impulsionando o desenvolvimento do mercado de áreas contaminadas, sua identificação e o gerenciamento dos passivos ambientais associados.

Considerando que a contabilidade dos custos associados ao meio ambiente é fator fundamental na avaliação do desempenho econômico de uma empresa, podendo afetar a sobrevivência das companhias, a valoração dos custos associados ao gerenciamento de áreas contaminadas é essencial. As demonstrações contábeis indicam a relação da empresa com o meio ambiente, a legislação vigente e a sociedade, e seu comprometimento com o desenvolvimento sustentável do negócio. De acordo com Tinoco e Kraemer (2008), a sociedade está aumentando a busca por informações ambientais na contabilidade das organizações e, segundo Constanza (2014), a valoração ambiental evidencia fatores econômicos importantes na tomada de decisões e contribui na tomada de decisões envolvendo seus ambientes (CONSTANZA, 2000; MENDESONHN \& OLMSTEAD, 2009; TURNER,et al., 1998).

Quando se avalia, ainda, que a valoração do dano ambiental é pressuposto necessário para reparação e indenização do dano, e que a estimativa dos custos e do tempo necessário à remediação de uma área contaminada é fundamental nos casos de fusões e aquisições de empreendimentos, assim como na obtenção de Termo de Ajustamento de Conduta (TAC) com o judiciário.

A complexidade da atividade de gerenciamento de áreas contaminadas, considerando a não existência de uma metodologia aceita pela comunidade científica, torna o processo de valoração antecipada do passivo ambiental processo empírica com forte demanda, considerando que não existe metodologia aceita pela comunidade científica para valorar os danos ambientais associados a áreas contaminadas. 
A Procuradoria-Geral de Justiça do Estado de São Paulo (PGJSP) desenvolveu após 2010 para obter a "fixação de diretrizes e, se possível, de metodologias de valoração do dano ambiental" através da criação de Grupos de Trabalhos (GT) específicos para o tema e, posteriormente, em 2012, no sentido de adequar, adaptar ou desenvolver métodos de valoração de danos ambientais (MPSP, 2014). Todavia, dentre os diversos grupos temáticos, o de áreas contaminadas (Subgrupo VI) apenas indicou possíveis hipóteses de como estabelecer uma metodologia de valoração do dano ambiental, não logrando êxito.

Esse assunto envolve julgamento e conhecimento específicos, daí a necessidade do desenvolvimento de uma metodologia simplificada de valoração do dano ambiental decorrente da contaminação de terrenos, de forma a fornecer subsídios às questões de planejamento financeiro e econômico das empresas, registros contábeis, assim como para engenheiros, advogados, juristas, etc.

Quando da ocorrência de uma área contaminada, esta ocasiona dano ambiental que afeta o valor do imóvel, ocasionando perdas no uso real ou potencial do mesmo, riscos financeiros e legais associados, refletindo na negociabilidade no mercado.

Em projetos de empreendimentos imobiliários, na avaliação da viabilidade econômica de sua implantação e tomada de decisão de continuidade, há a necessidade de caracterizar e valorar os custos associados ao gerenciamento de áreas contaminadas, bem como os riscos decorrentes do dano ambiental. Segundo Marker (2013), a estimativa de custos e tempo necessários para o controle e correção da contaminação é fundamental para a avaliação da viabilidade dos projetos imobiliários, em função dos riscos financeiros, legais e ambientais (Figura 2.1). 


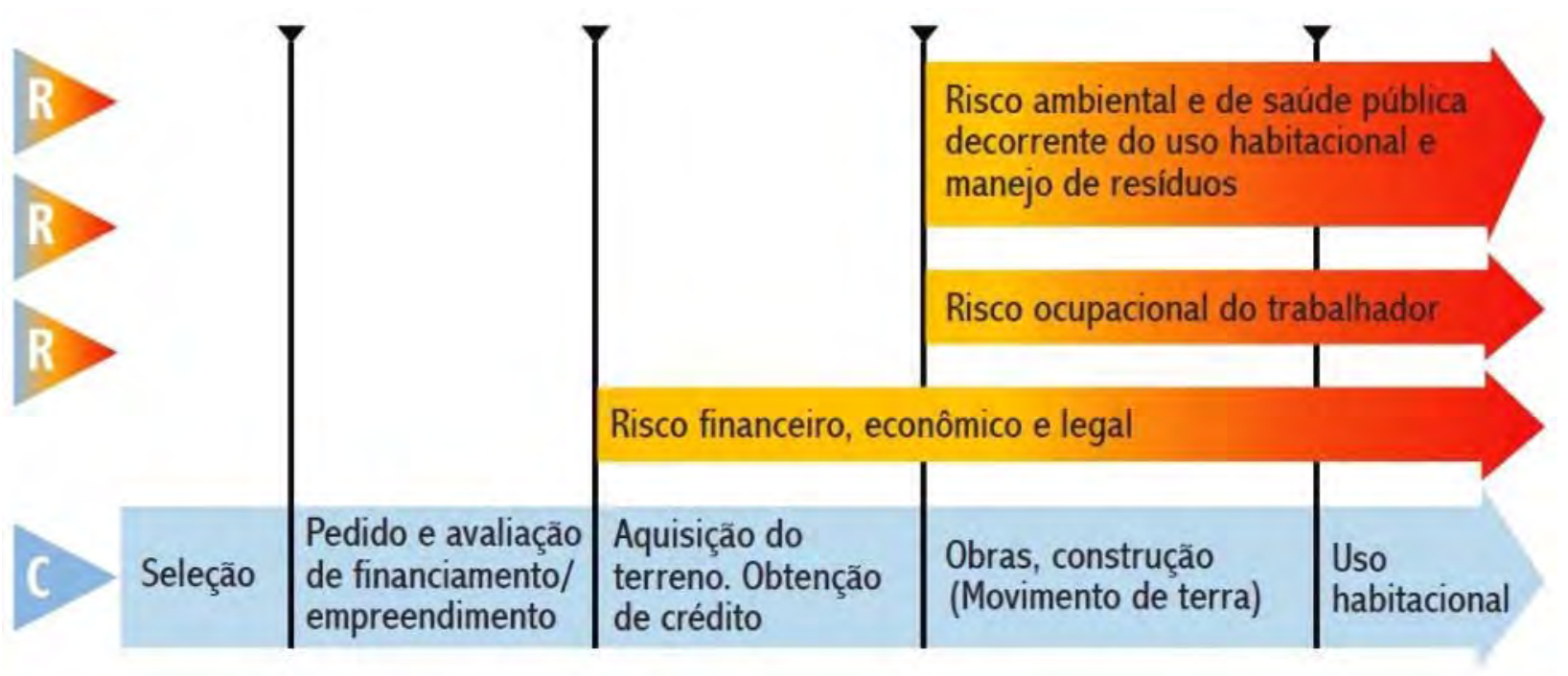

Implantação do

empreendimento imobiliário
Incidência e

relevância de riscos

Figura 2.1 - Incidência de riscos ao longo do desenvolvimento de um empreendimento imobiliário (MARKER, 2013)

Assim, é mister, o desenvolvimento de metodologia de quantificação dos custos associados à caracterização e recuperação dos danos ambientais reversíveis, bem como a de reparação dos irreversíveis de uma área contaminada (após a Investigação Confirmatória), de forma a prover subsídios necessários à valoração do dano ambiental associado às áreas contaminadas e possibilitar o correto planejamento econômico e financeiro dos empreendimentos, de comercialização dos imóveis e minimizar os riscos legais. 


\section{OBJETIVO}

A presente tese tem por objetivo propor uma metodologia de quantificação para a valoração antecipada da caracterização e reparação do dano ambiental reversível associado às áreas contaminadas por combustíveis fósseis, a partir dos dados obtidos quando do término da Investigação Confirmatória (conforme padrão estabelecido na Decisão de Diretoria nº 38 da CETESB, de 17 de Fevereiro de 2017).

Tal metodologia visa suprir uma deficiência observada no mercado nacional e internacional, já que não ser identifica propostas de quantificação das ações de investigação e valoração da remediação a partir da identificação da área contaminada, apenas.

Tem, ainda, como objetivo secundário, contribuir para o conhecimento do dano ambiental irreversível e sua compensação.

Pretende-se, com isso, colaborar para que o tema seja melhor compreendido e para que a metodologia proporcione melhores subsídios na tomada de decisão na gestão ambiental. 


\section{METODOLOGIA}

A presente Tese foi desenvolvida em sete etapas, a saber:

I. Pesquisa e revisão bibliográfica

Foram desenvolvidas pesquisas e revisão bibliográfica sobre três temas distintos de valoração ambiental: do imóvel, das ações de gerenciamento de áreas contaminadas por combustíveis fósseis e do dano ambiental irreversível associado.

Essa investigação técnico / científica visou, entre outros objetivos, a identificação e o levantamento de normas técnicas, aspectos legais e trabalhos científicos associados ao tema, de forma a definir o estado da arte do conhecimento sobre o assunto, fornecendo subsídios ao trabalho e definindo o ponto de partida para o desenvolvimento do mesmo, considerando o objetivo proposto.

II. Levantamento de dados de Gerenciamento de Áreas Contaminadas (GAC)

Efetuou-se levantamento de dados de áreas contaminadas em empresas distribuidoras e atacadistas de combustíveis, bem como em empresas de consultoria ambiental, objetivando a obtenção de parâmetros de referência, a conceituação do problema e possíveis limitações e abrangência de aplicações da valoração do dano ambiental associado a combustíveis fósseis.

Foram levantados mais de 2.000 relatórios de investigação de áreas contaminadas por combustíveis fósseis no estado de São Paulo e um número não determinado de documentos relativos a investigações no Brasil, cerca mais de 250 gigabytes de informações.

Os dados representativos do Estado de São Paulo foram, inicialmente, avaliados quanto a sua qualidade e representatividade das etapas de Gerenciamento de Áreas Contaminadas (GAC) em relação as informações contidas na lista de áreas contaminadas da CETESB em 2018 (CETESB, 2019). Foram selecionados relatórios representativos de áreas contaminadas situadas dos principais compartimentos geológicos do Estado de São Paulo e que apresentasse todos os relatórios processo de GAC da mesma, da Avaliação Preliminar ao encerramento das atividades. 
Os relatórios de GAC das áreas selecionadas foram parametrizados, com as atividades efetuadas inseridos em um grande banco de dados na forma de dados quantificáveis (datas de instalação, tamanho da área fonte, número de sondagens, profundidade de poços de monitoramento, número de análises químicas, datas, de início e fim de atividade, etc.).

III. Análise de dados de Gerenciamento de Áreas Contaminadas (GAC)

Os dados parametrizados de Gerenciamento de Áreas Contaminadas (GAC) foram analisados estatisticamente de forma a obter parâmetros representativos de quantitativos e prazos da investigação e remediação do dano reversível, quando existentes.

IV. Definição de modelo conceitual de quantificação para a valoração antecipada da caracterização e recuperação do dano ambiental originado por combustíveis fósseis

Com base nas informações técnicas, legais e econômicas levantadas e consolidadas sobre o tema de estudo, foi desenvolvido o modelo conceitual do problema.

V. Proposição do procedimento e equações de quantificação para a valoração antecipada da caracterização e recuperação do dano ambiental

Tendo, por base, o modelo conceitual do problema, bem como os parâmetros representativos dos procedimentos médios de GAC, foram desenvolvidos os procedimentos e as equações associadas à quantificação antecipada da caracterização e recuperação do dano ambiental, considerando: a) etapas de gerenciamento de área contaminada; b) quantificação das ações de investigação do dano; c) necessidade de ações de remediação do dano ambiental reversível; d) considerações do bem imóvel e dos serviços ambientais associados. 
VI. Validação e análise de sensibilidade da equação

A metodologia e equações propostas foram testadas para casos cadastrados de forma a validar a estimativa de quantitativos e custos associados a investigação e remediação do dano reversível, resultantes da metodologia proposta, através de um processo contínuo de prognósticos utilizando-se dados da Investigação Confirmatórias de casos conhecidos e cadastrados em etapas anteriores, comparando-se com as quantidades e prazos realmente desenvolvidos na prática.

Quando o erro obtido entre os prognósticos e os dados reais, em geral, foram inferiores a $15 \%$, o modelo foi considerado validado.

VII. Considerações

Foram efetuadas, em paralelo ao processo de preposição do modelo, análises conceituais quanto a valoração do bem imóvel e dos serviços ambientais potencialmente impactadas pela área contaminada, que devem ser considerados quando do planejamento físico e financeiro por parte das empresas responsáveis pelo dano ambiental.

Ao final, foram avaliados os resultados obtidos e registradas as conclusões, efetuando-se a avaliação das limitações da metodologia proposta (tanto sua aplicabilidade quanto sua representatividade e possíveis deficiências), de forma a subsidiar futuras melhorias.

A Figura 3.1 apresenta o fluxograma de pesquisa desenvolvido. 


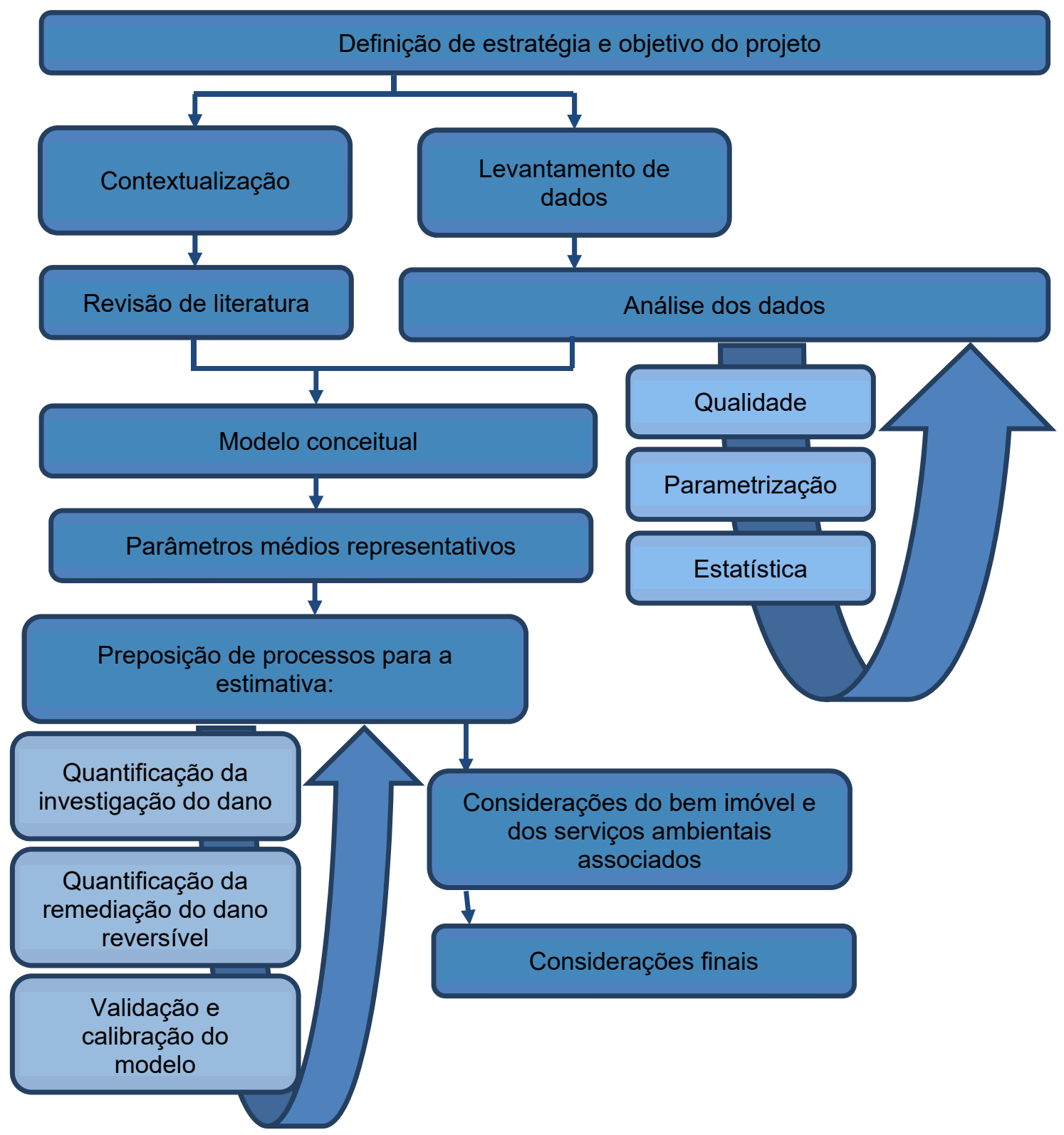

Figura 3.1 - Fluxograma de desenvolvimento da pesquisa. 


\section{A VALORAÇÃO DO DANO AMBIENTAL SOB A ÓTICA DO GERENCIAMENTO DE ÁREAS CONTAMINADAS}

\subsection{CONTEXTO LEGAL DO GERENCIAMENTO DE ÁREAS CONTAMINADAS E DO DANO AMBIENTAL}

\subsubsection{Legislação ambiental}

Segundo o site Jusbrasil (2018), a legislação ambiental brasileira é secular, pois:

$\checkmark$ No ano de 1605 foi publicada a primeira lei de cunho ambiental, o Regimento do Pau-Brasil, voltado à proteção das florestas.

$\checkmark$ Em relação a rios, nascentes e encostas, em 1797 foi promulgada a Carta Régia, afirmando a necessidade de proteção destes, sendo declarados propriedades da Coroa.

$\checkmark$ Em 1850 é promulgada a Lei $n^{\circ}$ 601/1850, primeira Lei de Terras do Brasil. Ela disciplina a ocupação do solo e estabelece sanções para atividades predatórias.

A Constituição da República Federativa do Brasil de 1988, referência de toda legislação atualmente em vigor, reconhece que qualidade de vida está intimamente ligada à qualidade do meio ambiente e atribui a responsabilidade civil ambiental através de uma gama de normas legais, baseadas no Art. 225 da CF (BRASIL, 1988), definindo:

Art. 225 - Todos têm direito ao meio ambiente ecologicamente equilibrado, bem de uso comum do povo e essencial à sadia qualidade de vida, impondo-se ao poder público e à coletividade o dever de defendê-lo e preservá-lo para as presentes e futuras gerações.

$\S 1^{\circ}$ Para assegurar a efetividade desse direito, incumbe ao poder público:

I - preservar e restaurar os processos ecológicos essenciais e prover o manejo ecológico das espécies e ecossistemas; 
$\S 2^{\circ}$ Aquele que explorar recursos minerais fica obrigado a recuperar o meio ambiente degradado, de acordo com solução técnica exigida pelo órgão público competente, na forma da lei.

$\S 3^{\circ}$ As condutas e atividades consideradas lesivas ao meio ambiente sujeitarão os infratores, pessoas físicas ou jurídicas, a sanções penais e administrativas, independentemente da obrigação de reparar os danos causados.

A Política Nacional do Meio Ambiente (PNMA) é definida pela Lei 6.938/81 (BRASIL, 1981), seus fins e mecanismos de formulação e aplicação, inclusive determinando importantes conceitos legais, como poluição, degradação, poluidor e meio ambiente. Define, ainda, a estrutura administrativa de proteção e de planejamento ambiental - o Sistema Nacional do Meio Ambiente (SISNAMA) e define, no inciso VIII do Art.2 ${ }^{\circ}$, a recuperação de áreas degradadas como um objetivo da Política Nacional do Meio Ambiente.

A legislação ambiental brasileira adota a responsabilidade objetiva quanto a responsabilidade civil pela ocorrência da poluição e degradação ambiental (independe da caracterização da culpa), utilizando a doutrina e jurisprudência a partir dos conceitos de poluição e degradação, previstos no Artigos $3^{\circ}$ e $14^{\circ}$ da Lei 6.938/81:

Art. $3^{\circ}$ - Para os fins previstos nesta Lei, entende-se por:

II - degradação da qualidade ambiental, a alteração adversa das características do meio ambiente;

III - poluição, a degradação da qualidade ambiental resultante de atividades que direta ou indiretamente:

a) prejudiquem a saúde, a segurança e o bem-estar da população;

b) criem condições adversas às atividades sociais e econômicas;

c) afetem desfavoravelmente a biota;

d) afetem as condições estéticas ou sanitárias do meio ambiente;

e) lancem matérias ou energia em desacordo com os padrões ambientais estabelecidos; 
IV - poluidor, a pessoa física ou jurídica, de direito público ou privado, responsável, direta ou indiretamente, por atividade causadora de degradação ambiental;

Art.14ํ - Sem prejuízo das penalidades definidas pela legislação federal, estadual e municipal, o não cumprimento das medidas necessárias à preservação ou correção dos inconvenientes e danos causados pela degradação da qualidade ambiental sujeitará os transgressores:

$\S 1^{\circ}$ - Sem obstar a aplicação das penalidades previstas neste artigo, é o poluidor obrigado, independentemente da existência de culpa, a indenizar ou reparar os danos causados ao meio ambiente e a terceiros, afetados por sua atividade. $O$ Ministério Público da União e dos Estados terá legitimidade para propor ação de responsabilidade civil e criminal, por danos causados ao meio ambiente.

A legislação considera uma tríplice responsabilização ambiental, pois define as responsabilidades conforme apresentado na Figura 4.1.

I. Responsabilidade civil (Lei 6938/81), que dispõe sobre as sanções penais e administrativas derivadas de condutas e atividades lesivas ao meio ambiente (BRASIL, 1981). O instrumento define que os danos ao meio ambiente devem ser integralmente reparados/indenizados pelo causador. Causador do dano é todo aquele que, de alguma forma (inclusive por omissão), colaborou para sua ocorrência, independente de culpa. A omissão na quebra da continuidade de um dano que se reproduz ao longo de um tempo é considerada causador de dano.

II. Responsabilidade administrativa e criminal, com base na Lei 9605/98 (BRASIL, 1998), que dispõe sobre as sanções penais e administrativas derivadas de condutas e atividades lesivas ao meio ambiente, e dá outras providências. $\mathrm{O}$ Decreto 6.514/2008 (BRASIL, 2008) que regulamenta a Lei 9605/98, estabeleceu a responsabilidade subjetiva para a responsabilidade criminal, havendo, assim, a necessidade de comprovação de dolo ou culpa do responsável pelo dano ambiental. 


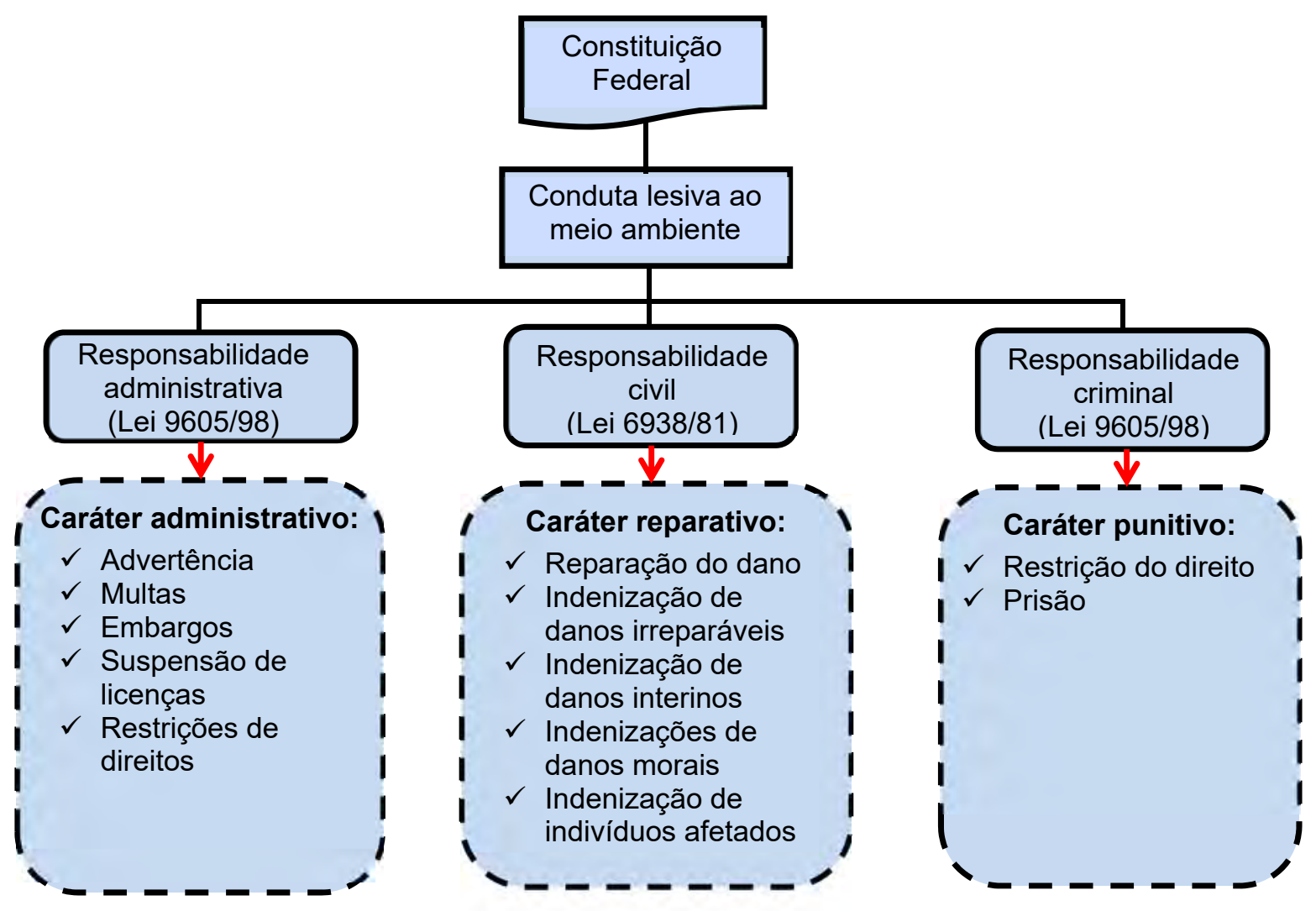

Figura 4.1 - Tríplice responsabilização ambiental atribuída pela legislação brasileira, organizada pelo autor.

De uma maneira geral, a legislação ambiental considera sanções de cunho moral (advertência), associadas ao patrimônio (multas, reparações e indenizações), e restrições do direito através da limitação da liberdade. Ela está baseada pelos princípios básicos:

\section{Da prevenção e da precaução}

Estabelece que todos devemos tomar medidas de prevenção e precaução ao dano ambiental. Precaução em relação aos riscos conhecidos e prevenção em relação a possíveis riscos desconhecidos.

Considerando que o meio ambiente, uma vez alterado, dificilmente retorna à situação original, este, talvez, seja o mais importante dos princípios que visam a defesa do meio ambiente.

\section{Do poluidor pagador}

O agente causador da poluição, da alteração ou do dano ambiental, é responsável pelo ônus de sua reparação, seja por culpa, ou por omissão. 
Este princípio associa a ideia de penalidade ao tema de proteção ambiental, uma vez que estabelece que danos ocasionados por alguém, terão associados uma responsabilidade.

\section{Da reparação}

Tema controverso atualmente, uma vez que: a) não estabelece possíveis limitações para a obtenção desta reparação; b) não considera que o meio ambiente, uma vez tendo sofrido o dano, dificilmente será recuperado na íntegra; e c) não estabelece ações para a permanência ou compensação de possível dano residual remanescente após a ação de reparação.

\subsubsection{Aspectos da legislação do dano ambiental}

A Constituição Federal em seu Art. 225 define que "o meio ambiente é um bem de uso comum e essencial à sadia qualidade de vida" e direitos e deveres em relação ao mesmo, sem, no entanto, conceituá-lo.

A definição do meio ambiente é inicialmente estabelecida no Art. $3^{\circ}$, I, da Lei n. ${ }^{\circ} 6938 / 81$, como "o conjunto de condições, leis, influências e interações de ordem física, química e biológica, que permite, abriga e rege a vida em todas as suas formas" (MACHADO, 2009). Mesmo assim, o conceito é abstrato e pode variar, sob o aspecto físico em função de sua região, e sob o aspecto de sua percepção, em função da cultura de quem o vê e o sente.

Sabe-se o que meio ambiente é algo, mas não é definido de forma única, e esta situação deve ser considerada quando da avaliação da valoração do dano ambiental. Para fins desta tese, o meio ambiente é o próprio imóvel, o terreno em si e seu entorno, suas benfeitorias e seu uso.

Assim, o meio ambiente apresenta uma definição subjetiva e variável. Quando se fala em responsabilização e reparação do dano ambiental, a área do direito recorre a "defesa do equilíbrio ecológico constitucional garantido" (PINHEIRO DA SILVA e SCHUTZ, 2018), buscando estabelecer, conceitualmente, que dano ambiental é falta de equilíbrio, alteração da condição inicial de qualidade da área. 
Como base para o estabelecimento do dano ambiental, utiliza-se a definição especificada no Artigo $3^{\circ}$, incisos II e III da Lei $n^{\circ}$ 6.938/1981, as noções de alteração e a degradação da qualidade ambiental e poluição, citado anteriormente.

A especificação do inciso III é a base para a definição de alteração ambiental definida na Resolução do CONAMA n. ${ }^{\circ} 001$ de 23/01/81, como "qualquer alteração das propriedades físicas, químicas e biológicas do meio ambiente, causada por qualquer forma de matéria ou energia resultante das atividades humanas que, direta ou indiretamente, afetem: (I) a saúde, a segurança e o bem-estar da população; (II) as atividades sociais e econômicas; (III) a biota; (IV) as condições estéticas e sanitárias do meio ambiente; (V) a qualidade dos recursos ambientais".

Esta definição de alteração diferencia-se pelo estabelecido na norma de gestão ambiental NBR ISO14001, em seu requisito 3.4.1, que define a alteração ambiental como "qualquer modificação do meio ambiente, adversa ou benéfica, que resulte no todo ou em parte, das atividades, produtos ou serviços de uma organização".

A área do direito ambiental utiliza a definição de Paulo Bessa Antunes (como um prejuízo ao meio ambiente): "Dano ambiental é a lesão aos recursos ambientais, com consequente degradação do equilíbrio ecológico e da qualidade de vida." (MILARÉ, 2001). O dano ambiental possui uma conceituação ambivalente, e atinge, de forma direta, a coletividade quando causar prejuízos ao meio ambiente e, de forma indireta, poderá atingir, eventualmente, a terceiros (MILARÉ, 2007). A Lei nº 6.938/1981 prevê, de forma expressa, as duas modalidades, no Art. $14, \S 1^{\circ}$, ao dizer que é o poluidor obrigado, independentemente da existência de culpa, a indenizar ou reparar os danos causados ao meio ambiente e a terceiros, afetados por sua atividade.

O Art. $4^{\circ}$, $\S$ VII, da Lei $n^{\circ} 6.938 / 1981$ prevê duas modalidades principais de reparação do dano, com a imposição ao poluidor da obrigação de recuperar e/ou indenizar os danos causados. A primeira, visa a reintegração ou recuperação dos bens afetados para a situação anterior e, a segunda, a compensação do dano nos bens afetados, seja na forma financeira ou fornecendo outros bens de funcionalidade equivalente, mesmo que em locais diferentes.

Entretanto, cabe ressaltar o conceito que, de uma forma geral, o dano ambiental é irreparável, uma vez que o meio ambiente apresenta características únicas que, mesmo refeitas, nunca serão iguais às originais. 
Considerando que um dano é entendido como um prejuízo ou perda em relação a um bem ou patrimônio, decorrente de uma inutilização ou diminuição de seu valor em função de uma ação ocorrida, somente podemos valorar o dano ambiental quando valoramos os bens iniciais envolvidos, isto é, o imóvel e os serviços ambientais decorrentes do meio ambiente no qual está inserido.

A Lei 6.938/81 e suas modificações posteriores, estabelecem em seu inciso VIII do Art. $2^{\circ}$, o princípio da "reparação de áreas degradadas" e, para tanto, fixa, dentre seus objetivos, a "restauração dos recursos ambientais com vista a sua utilização racional e disponibilidade permanente, concorrendo para a manutenção do equilíbrio ecológico propício à vida" (Art. $4^{\circ}, \S \mathrm{VI}$ ), bem como a "imposição, ao poluidor e ao predador, da obrigação de recuperar e/ou indenizar os danos causados e, ao usuário, da contribuição pela utilização de recursos ambientais com fins econômicos" (Art. $4^{\circ}$, § VII).

Entretanto, apesar da legislação ter um amplo aspecto na sociedade, influenciando a todos (tanto os que a obedecem quanto os que a transgridem), até o momento, não existe uma definição para o que é dano ambiental!

Podemos definir como dano ambiental um impacto negativo ao meio ambiente, decorrente de um evento produzido pelo homem ou não, com perda da qualidade frente a um padrão de referência, seja ele pré-estabelecido ou posteriormente estabelecido ao evento de contaminação em análise.

\subsubsection{Reparação do dano ambiental associado as áreas contaminadas no Estado de São Paulo}

A obrigatoriedade da reparação do dano ambiental (apesar de não existir uma definição legal para o dano ambiental, propriamente dito) é definida pela Constituição do Estado de São Paulo de 1989, em seu Art. 193:

O Estado, mediante lei, criará um sistema de administração da qualidade ambiental, proteção, controle e desenvolvimento do meio ambiente e uso adequado dos recursos naturais, para organizar, coordenar e integrar as ações de órgãos e entidades da administração pública direta e indireta, assegurada a participação da coletividade, com o fim de: 
XIV - promover medidas jurídicas e administrativas de responsabilização dos causadores de poluição e degradação ambiental; (...)

$X X$ - controlar e fiscalizar obras, atividades, processos produtivos e empreendimentos que, direta ou indiretamente, possam causar degradação do meio ambiente, adotando medidas preventivas ou corretivas e aplicando as sanções administrativas pertinentes.

Em 1997, a Lei no 9.509/97 (SÃO PAULO, 1997) que define a Política Estadual do Meio Ambiente, seus fins e mecanismos de formulação e aplicação, estabelece em seu Art. $2^{\circ}$ do capítulo I, entre outros, a prevenção e recuperação do meio ambiente degradado, a informação da população sobre o nível da poluição e a obrigação do poluidor de recuperar danos causados.

A Lei 13.577/2009 (SÃO PAULO, 2009a), regulamentada pelo Decreto 59.263/2013 (SÃO PAULO, 2013a) e pela Decisão de Diretoria da CETESB DD38/2017 (CETESB, 2017), consolidou as normas e procedimentos para a proteção da qualidade do solo, definindo as responsabilidades e a identificação e o respectivo cadastramento de áreas contaminadas, sendo o referido cadastro realizado pela CETESB.

O Art. $23^{\circ}$ da Lei 13.577/09 define o termo "área contaminada" e que a mesma deve ser remediada quando forem ultrapassados os valores de risco aceitáveis à vida, à saúde

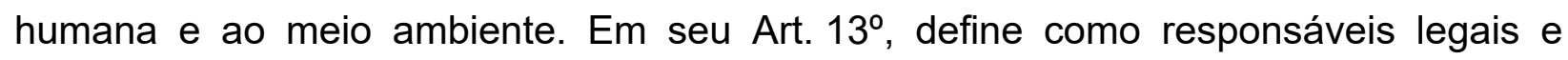
solidários pela prevenção, identificação e remediação de uma área contaminada:

I - o causador da contaminação e seus sucessores;

Il - o proprietário da área;

III - o superficiário;

IV - o detentor da posse efetiva;

$V$ - quem dela se beneficiar direta ou indiretamente.

O Art. 26 da mesma lei, define que será considerada área remediada quando for restabelecido nível de risco aceitável para o uso declarado, sendo esta a condição final prevista nos procedimentos das ações de remediação com base no risco. 
Cabe destacar que existem divergências na interpretação da legislação ambiental, como é o caso, na presente data, do entendimento pelo MP-SP da Lei Estadual 13.577/09 e do Decreto Estadual 59.263/2013, que as mesmas apresentam artigos inconstitucionais, pois a responsabilidade é objetiva e solidária ao poluidor direto e indireto e que existe a obrigatoriedade de remediação (reparação) integral da área contaminada em detrimento aos conceitos de remediação baseados na análise de risco toxicológico (ARtx). Segundo o MP-SP, a própria análise de ARtx definida pela CETESB seria inadequada para o atendimento ao conceito de "meio ambiente ecologicamente equilibrado" definido pela CF (BRASIL, 1988), e que a mesma deveria incluir uma análise ecotoxicológica completa.

Esta é uma discussão que permeia todo o gerenciamento de área contaminada no Estado de São Paulo no momento e, por ser referência no Brasil, deve ser considerada e acompanhada, apesar de não ser objeto dessa tese.

O Decreto 59.263/2013 (que regulamenta a Lei 13.577/2009) prevê penalidades administrativas caso ocorra o não cumprimento ou atendimento das exigências estabelecidas pela CETESB (órgão competente do Estado de São Paulo): advertência, multa, embargo, demolição e embargo de financiamento de benefícios fiscais em função de:
a) Antecedentes do infrator e, se pessoa jurídica ou física.
b) Da intensidade do dano, seja efetivo ou potencial.
c) Das circunstâncias atenuantes ou agravantes.

\subsection{VALOR ECONÔMICO DO BEM IMPACTADO}

Como parte do processo de valoração do dano ambiental decorrente da área contaminada, inicialmente, há a necessidade de conceituar e valorar o bem sem a ocorrência da área contaminada, assim como os serviços ecossistêmicos em que o mesmo está inserido. 


\subsubsection{Valoração econômica do imóvel impactado}

Segundo Michael (2004), a avaliação de um imóvel é o valor de mercado mais provável que este imóvel atingiria em uma dada transação, de acordo com suas características e condições do mercado naquele momento. Pelli Neto (2003) define que o valor está associado a variáveis que envolvem suas características físicas, seu entorno, uso e fatores subjetivos que a coletividade cria, sendo um fenômeno social.

Em relação ao processo de avaliação do imóvel, segundo Dantas (2003), é necessário um amplo conjunto de conhecimentos das áreas de ciências exatas, da natureza e sociais, de forma a determinar o valor de um bem, de seus direitos, frutos e custos de produção.

O procedimento de avaliação pode variar em função de seu objetivo (judicial, para gestão patrimonial, venda, etc.), mas possui métodos e procedimentos normatizados no Brasil através das normas brasileiras da ABNT:

$\checkmark$ NBR 14653-1 - Avaliação de bens - Parte 1: Procedimentos gerais.

$\checkmark$ NBR 14653-2 - Avaliação de bens - Parte 2: Imóveis urbanos.

$\checkmark$ NBR 14653-3 - Avaliação de bens - Parte 3: Imóveis rurais.

$\checkmark$ NBR 14653-4 - Avaliação de bens - Parte 4: Empreendimentos.

Além das quatro normas acima citadas, a série NBR 14653 conta com mais três outras normas que versam sobre avaliações de bens e direitos:

$\checkmark$ NBR 14653-5 - Avaliação de bens - Parte 5: Máquinas, equipamentos, instalações e bens industriais em geral.

$\checkmark$ NBR 14653-6 - Avaliação de bens - Parte 6: Recursos naturais e ambientais.

$\checkmark$ NBR 14653-7 - Avaliação de bens - Parte 7: Patrimônios históricos.

Dentre as diversas formas de avaliar o imóvel, cinco principais métodos se destacam: 
a) Método comparativo dos dados do mercado

O Método comparativo dos dados do mercado ou MCDM atribui um valor considerando os preços pagos no mercado para imóveis similares. O valor atribuído é, assim, uma média dos valores de imóveis comercializados na região e sua representatividade é diretamente proporcional ao número de amostras consideradas, havendo a necessidade de existência de imóveis semelhantes ao que está sendo avaliado. Este é o método mais utilizado no mercado imobiliário.

b) Método comparativo do custo de reprodução

O Método comparativo do custo de reprodução (ou de substituição) do bem considera que o valor de um imóvel é igual ao custo de execução da edificação, acrescido do custo do terreno (avaliado usando o método comparativo dos dados de mercado). Tem como premissa que o comprador não pagará mais do que o custo de produzir uma propriedade igual e substituta àquela que esteja em negociação.

c) Método da renda

O Método da renda estabelece que o valor de um imóvel é representado pelo valor atual dos benefícios futuros que resultam do direito de sua propriedade. Um investidor adquire uma propriedade pelos benefícios que ela há de lhe proporcionar, quer seja para seu próprio uso, quer seja pela renda que produzirá se for arrendada.

Assim, o método atribui um valor pelo potencial de renda que este poderá trazer ao comprador (frente a uma renda bruta estimada, subtraída dos custos do trabalho e juros sobre o capital), avaliada por um histórico do próprio imóvel ou de imóveis similares.

d) Método involutivo

O Método involutivo atribui um valor decorrente da capacidade de utilização do terreno, sendo, também, denominado "método do máximo aproveitamento eficiente". 
Assim, o valor atribuído apresenta forte conexão com a lei de zoneamento urbano a que o imóvel está sujeito, uma vez que a mesma estabelece o uso e o número de metros quadrados possíveis a serem construídos naquele terreno e, consequentemente, torna possível quantificar um potencial de renda de negócio.

e) Método evolutivo ou residual

O Método evolutivo atribui um valor pela somatória de valores representativos para os diversos aspectos que constitui o imóvel: terreno, construção, potencial de ganho.

Cabe destacar que a legislação brasileira diferencia o direito de propriedade do imóvel e o direito de uso e gozo, através das figuras do nu-proprietário e do usufrutuário, respectivamente. O usufruto é um direito real, previsto no Art. 1225 do Código Civil (BRASIL, 2002), sendo que o seu titular pode fruir as utilidades e receber os frutos de um bem, o qual pertence a um terceiro indivíduo.

De uma forma indireta, o Estado de São Paulo estabelece o valor do usufruto correspondente a $33 \%$ do valor do imóvel. Estabelece a previsão de recolher o imposto devido ITCMD (Imposto sobre Transmissão "Causa Mortis" e Doação) sobre a totalidade do valor (100\%), ou, ainda, sobre a nua-propriedade equivalente a $2 / 3$ do valor no momento da doação, postergando-se o recolhimento do valor correspondente ao usufruto equivalente a $1 / 3$, o qual deverá, neste caso, ser recolhido no momento do seu cancelamento (SÃO PAULO, 2002).

\subsubsection{Valoração econômica dos serviços ambientais ou ecossistêmicos}

Os serviços ambientais são os benefícios que a sociedade e as pessoas recebem do meio ambiente (ALCAMO et al., 2003), representando, assim, contribuições diretas e indiretas dos ecossistemas ao bem-estar humano. $O$ valor de serviço ambiental, segundo Marques e Comune (1995, apud NOGUEIRA et al. 2000), reflete o valor do recurso associado a sua presença e interação com o meio ambiente, independentemente de seu uso atual pelo Homem. O valor é decorrente de sua importância e participação, como, por exemplo, na manutenção do ciclo hidrogeológico (armazenamento e percolação da água subterrânea), no fornecimento de nutrientes para as plantas (minerais e orgânicos), na manutenção da micro fauna no subsolo, etc., tanto hoje como no futuro. 
A importância dos serviços ecossistêmicos é tão significativa que, os mesmos não são substituíveis pelo capital físico e tecnológico desenvolvido pelo homem (TEEB, 2012b), e mesmo quando a substituição é possível, ela tende a ser apenas parcial e pode nem mesmo ser eficiente do ponto de vista econômico (MONZONI et al., 2014).

Segundo Pearce et al. (1991), quando da valoração, devem ser observadas:

$\checkmark$ Irreversibilidade do recurso.

$\checkmark$ Incertezas quanto à importância do recurso.

$\checkmark$ Singularidade dos cenários e da existência de espécies em extinção.

Segundo Sukhdev et al. (2010), tanto os atributos quantitativos quanto os qualitativos da biodiversidade são importantes nas relações entre a natureza, a atividade e o bem-estar humanos. Estes mesmos autores indicam que os conceitos do capital natural e dos serviços ecossistêmicos podem nos ajudar a reconhecer os diversos benefícios da natureza para as pessoas, que podem ser considerados "dividendos".

Considerando a percepção de valor do meio ambiente expressa no Art. 225 da CF de 1988, em que o meio ambiente é um bem de uso comum do povo e essencial à sadia qualidade de vida para a sociedade atual e futuras gerações, qualquer que seja o valor atribuído ao serviço ambiental será temporário e variável ao longo do tempo.

A manutenção destes serviços é uma necessidade de sustentabilidade do bem estar do Homem e o valor dos serviços ambientais, pode, segundo Peixoto (2002), ser classificado em duas categorias:

a) Valor de uso, refletindo o valor atribuído ao recurso natural pelo seu uso no presente ou seu uso potencial no futuro, podendo atribuir preços de mercado praticados ou substitutos.

b) Valor de não uso, associados ao valor independente do uso, pela sua própria existência, o que, segundo diversas bibliografias, é de difícil mensuração.

Segundo Fonseca et al. (2013), é necessária a estimativa dos valores de uso e de não uso de forma a possibilitar políticas de conservação e preservação do meio ambiente. Estes valores podem servir de base na aplicação de taxas e multas associadas aos danos ambientais (FINCO, 2004). 
Existem diversas bibliografias sobre metodologias de valoração dos serviços ambientais, dentre elas destacam-se as apresentadas na Tabela 4.1.

Tabela 4.1 - Principais metodologias de valoração de serviços ambientais existentes na literatura organizadas e avaliadas pelo autor dessa tese.

\begin{tabular}{|c|c|}
\hline METODOLOGIA & DESCRIÇÃO \\
\hline Custo de viagem & $\begin{array}{l}\text { Valor que se paga para usufruir o bem, tendo por base os gastos dos usuários } \\
\text { frequentes do bem ambiental }\end{array}$ \\
\hline Preço hediônico & $\begin{array}{l}\text { Valora através da diferença do valor de mercado da propriedade com e sem o dano } \\
\text { ambiental }\end{array}$ \\
\hline Custo de reposição & $\begin{array}{l}\text { Estabelece o valor considerando os custos necessários para repor o bem ambiental } \\
\text { prejudicado }\end{array}$ \\
\hline Custo evitado & $\begin{array}{l}\text { Avalia tendo por base o valor de substituição do bem sem alterar a quantidade e } \\
\text { qualidade do recursos }\end{array}$ \\
\hline $\begin{array}{l}\text { Produtividade } \\
\text { marginal }\end{array}$ & $\begin{array}{l}\text { Quantifica o valor do bem para a a atividade humana (produção), considerando as } \\
\text { perdas pela falta do mesmo }\end{array}$ \\
\hline $\begin{array}{l}\text { Transferência de } \\
\text { beneficio }\end{array}$ & Utiliza valores estimados em áreas semelhantes, por analogia \\
\hline Valoração contigente & $\begin{array}{l}\text { Estabelece o valor da disposição da população a pagar pelo bem ambiental, obtido } \\
\text { através de entrevistas }\end{array}$ \\
\hline Custo de oportunidade & $\begin{array}{l}\text { Atribui o valor associado às perdas de renda devido às restrições impostas pelo } \\
\text { dano, consumo do bem e ações para conservar ou preservar os recursos ambientais }\end{array}$ \\
\hline
\end{tabular}

Os serviços ambientais, segundo proposta da Avaliação Ecossistêmica do Milênio (MEA, 2003) podem ser divididos em:

Serviços de provisão - Associados à produção de todo tipo de material obtido pelo ecossistema (alimentos, água doce, lenha, fibras, bioquímicos, recursos genéticos, etc.) e consumidos pelas pessoas.

Serviços de regulação - Serviços de regulação dos processos ambientais, ou seja, condicionam o bem estar das pessoas à qualidade do ar e da água, controle do clima e das doenças, polinização, controle climático e hídrico.

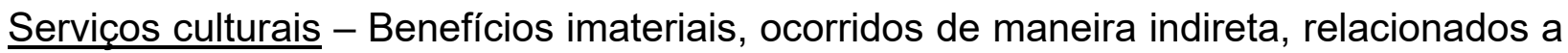
ideia de uso do espaço para fins religiosos, recreação e ecoturismo, estético, herança cultural e estética, entre outros.

Serviços de suporte - Ligados à formação de solos, ciclo dos nutrientes, habitats para espécies, produção primária e outras funções. 
Quanto maior a biodiversidade existente no imóvel, maior serão suas complexidades estruturais e o número de funções ecológicas neles presentes e, consequentemente, o valor de seus serviços ambientais. Entretanto, quando se fala de uma propriedade situada em uma zona urbana, deve-se observar o aumento da importância dos serviços preservados, considerando que já desapareceram, na região, muitos dos serviços ambientais decorrentes da ocupação urbana da área e seu entorno.

Segundo TEEB (2012), o valor dos serviços ecossistêmicos varia em função da percepção da sociedade quanto aos aspectos: a) ecológicos, em relação à provisão dos benefícios dos ecossistemas; b) sociocultural, em relação às crenças e valores culturais da comunidade, e; c) econômica, em relação ao uso e consequente bem-estar social.

Os serviços ambientais em áreas urbanas, para fins desta pesquisa, que podem ser impactados diretamente pela ocorrência da contaminação em imóveis situados nos centros urbanos, foram: provisão de água doce, regulação da qualidade da água e dos recursos hídricos, serviços culturais associados ao uso do espaço e suporte à formação dos solos, produção primária e ciclo de nutrientes. Assim, estes foram reagrupados e consolidados em:

a) Serviços ambientais hídricos

$\checkmark$ provisão de água potável ou não (uso direto);

$\checkmark$ regulação da qualidade das águas superficial e subterrânea (armazenamento e descarga)

suporte e manutenção do recurso hídrico (manutenção do ciclo hidrogeológico). b) Serviços ambientais do solo

$\checkmark$ formação de solos;

suporte a vida;

$\checkmark$ habitat para espécies.

c) Serviços culturais:

$\checkmark$ uso histórico do espaço;

bens a proteger.

Cabe destacar que a Lei Estadual de São Paulo n 13579/2009 (SÃO PAULO, 2009a), Lei Específica APRM Billings, no $\S 8^{\circ}$ do Art. $2^{\circ}$ - indica que "as áreas preservadas em decorrência desta lei poderão ser contempladas em programas de pagamento por serviços ambientais e outros mecanismos de incentivo financeiro, fiscal ou creditício, na forma definida em regulamento próprio". 
O Município de São Paulo através da Lei no 14933 (SÃO PAULO, 2009b), de 5 de junho de 2009, em seu Art. 36, definiu que “o Poder Público Municipal estabelecerá, por lei específica, mecanismo de pagamento por serviços ambientais para proprietários de imóveis que promoverem a recuperação, manutenção, preservação ou conservação ambiental em suas propriedades...". A lei municipal estabelece ainda, em seu $\S 1^{\circ}$, que "a propriedade declarada, no todo ou em parte, de preservação ambiental ou Reserva Particular do Patrimônio Natural - RPPN poderá receber incentivo da Administração Municipal, passível de utilização para pagamento de tributos municipais, lances em leilões de bens públicos municipais ou serviços prestados pela Prefeitura Municipal de São Paulo em sua propriedade".

Considerando o acima exposto, e que a sociedade reconhece o valor dos serviços ambientais e, ainda, admitindo o conceito da reciprocidade, quando os serviços ambientais sofrerem dano, o responsável legal deve ser penalizado, além da obrigação da reparação do dano.

Várias metodologias de valoração ambiental direta são aplicadas de forma a atender as diversas necessidades judiciais, tais como: CATES - Custos Ambientais Totais Esperados (RIBAS, 1996); VCP - Valor da Compensação Ambiental (IBAMA, 2002); AHE - Análise do Habitat Equivalente (NOAA, 2000); e Modelo do Departamento Estadual de Recursos Naturais do Estado de São Paulo (GALLI, 1996) que, em geral, são metodologias baseadas em métodos elaborados com base na experiência profissional dos técnicos e direcionadas a casos específicos com características diferentes de áreas contaminadas, de difícil e demorada aplicação em áreas urbanas e sem considerar a ocorrência de área contaminada.

Segundo Constanza et al. (1997), apesar da existência de vários métodos para estimar o valor econômico dos serviços ambientais, a maioria dos trabalhos de valoração de serviços ambientais ou ecossistêmicos utiliza o "Método contingente" (Contingent Valuation Method - CVM). Sua ampla utilização justifica-se por ser o mais fácil e barato de se aplicar através do uso de questionários que avaliam a predisposição das pessoas a pagar pelo "serviço" avaliado, sem, contudo, discriminar os tipos de serviços (ROMA et al., 2013). 
Ainda, segundo este mesmo autor, o método de transferência de valores é o segundo mais utilizado, sendo caracterizado por estudos rápidos e simples, que se utilizam de valores já caracterizados de outras áreas similares. Entretanto, a utilização de valores por similaridade deve ser avaliada quanto a representatividade, o contexto das áreas comparadas e quanto às limitações dos parâmetros obtidos. A vantagem é que, uma vez avaliada a área e aceitos os valores, estes podem ser aplicados de forma rápida para diversos imóveis (áreas) da região, município, bairro ou quadra.

Cabe destacar que, qualquer que seja o método aplicado, este deve considerar o objetivo do trabalho e que as informações disponíveis e a representatividade dos resultados obtidos, sempre serão em função da qualidade e da quantidade de dados existentes.

Em geral, os métodos de valoração consideram um intervalo de tempo adotado para análise do valor dos danos, a taxa de desconto dos valores do dano e até uma taxa de risco (percentual a ser acrescido no valor). Entretanto, quando se define o dano para área contaminadas, o valor de recuperação da área apenas pode ser aferido após sua conclusão ou através de uma estimativa empírica por um técnico com experiência na área, tendo por base valores de mercado dos serviços de engenharia, mão-de-obra e dos materiais necessários para executar o serviço de gerenciamento de área contaminada.

Porém, ainda não há metodologia de quantificação dos danos associados a áreas contaminadas, aceita ou não nos meios acadêmicos, profissionais ou mesmo periciais, para definir com a objetividade necessária, a valoração econômica do dano ambiental decorrente das áreas contaminadas.

Quando se trata de planejamento financeiro de uma empresa, relatórios contábeis anuais e processos de fusão e aquisição, bem como em decisões judiciais, deve-se recorrer a métodos diretos de valoração que quantifiquem o dano através do custo de sua reparação e da perda econômica decorrente da limitação do uso do bem devido à ocorrência da contaminação. 
Assim, no dia-a-dia das Promotorias de Justiça e das áreas técnicas que as assessoram, chegar a um dimensionamento o mais próximo possível do passivo ambiental, não raro, arvora-se num grande desafio, agravado pela crescente demanda na área do meio ambiente. Apesar da aplicação cada vez maior de modelos matemáticos de valoração de dano ambiental, os modelos disponíveis na literatura são limitados e não atendem à atual necessidade, em especial àqueles associados a impactos de áreas contaminadas. A metodologia de valoração ambiental recomendada pela ABNT NBR 14653-6 (2008), que indica a disposição a pagar ou a receber compensação pelo dano, define a expressão matemática (1) denominada VERA (Valor Econômico de Recurso Ambiental), encerra quatro formas de atribuição de valor, conforme expressa a Equação 4.1:

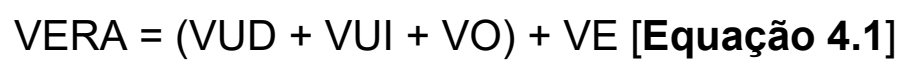

Onde:

VUD - Valor de Uso Direto, que os indivíduos atribuem ao bem ambiental por sua utilização direta, via extração ou consumo, ou de opção pelo consumo direto/indireto do bem. Por exemplo: uso do terreno para agricultura ou o aluguel do terreno.

VUI - Valor de Uso Indireto, atribuído ao bem ambiental pelo benefício obtido por intermédio das relações ecológicas entre os elementos de um ecossistema. Por exemplo: pela manutenção da reprodução de determinadas espécies de peixes de água doce com a conservação da mata ciliar dos cursos de água;

VO - Valor de Opção, conferido pelos indivíduos para preservação de recursos que podem ser utilizados de modo direto ou indireto no futuro próximo. Por exemplo: terapias provenientes de substâncias derivadas de plantas tropicais ainda não catalogadas;

VE - Valor de Existência, associado ao direito de existência de espécies distintas da humana e de riquezas naturais, por motivos altruístas, éticos, morais ou culturais, desvinculada da possibilidade de seu uso direto, indireto, presente ou futuro. 
A expressão, apesar de amplo embasamento teórico, utiliza-se de ferramentas de pesquisa para a determinação do valor ambiental de uso indireto, que corresponde às funções e serviços ecossistêmicos providos pelos recursos naturais à sociedade, os quais não têm valor econômico estabelecido. Assim, vários fatores podem influenciar no resultado, desde o momento cultural da população pesquisada até o nível de renda e instrução dos pesquisados, e necessita de longos prazos para sua determinação.

Quando se acrescenta os fatores das complexidades que envolvem a investigação, remediação do dano reversível e reparação do dano irreversível associados as áreas contaminadas, o mercado demanda por uma metodologia de quantificação e valoração, de forma a possibilitar a aplicação dos conceitos já amplamente utilizados na equação VERA.

\subsubsection{Serviços ambientais do solo}

Em relação ao solo, este é um complexo sistema constituído por minerais e compostos orgânicos, habitat de diversos microorganismos. Segundo Correia (2002), o solo e a fauna microbiana que o habita, sustentam a vegetação na superfície e possibilitam a reciclagem dos nutrientes. Os solos superficiais tendem a apresentar uma maior concentração e diversidade de microorganismos que os solos mais profundos.

Considerando que o solo suporta a flora, este caracteriza-se como fator de influência indireta na regulação da qualidade do ar em ambientes terrestres, efetuando a manutenção do equilíbrio do $\mathrm{CO}_{2} / \mathrm{O}_{2}$ da atmosfera, bem como, a remoção do $\mathrm{CO}_{2}$ através de sua captura pela dissolução do gás na água atmosférica, posterior precipitação e infiltração no subsolo e posterior imobilização através da cristalização minerais ricos em $\mathrm{CO}_{2}$. Segundo De Groot et al. (2002), a função de regulação do ar está associada à manutenção geral de um planeta habitável através da limpeza dos gases atmosféricos, manutenção do ar respirável e da prevenção de doenças (câncer de pele, por exemplo).

Pouco se conhece da diversidade das espécies no solo, entretanto, é consenso que um dos aspectos funcionais do solo é a reciclagem de nutrientes do ecossistema, fundamental para o crescimento vegetal (CORREIA, 2002). 
A ocorrência dos contaminantes no solo pode afetá-lo em diversos graus. Na pior hipótese, a contaminação inviabiliza, por completo, os serviços ambientais associados ao ciclo de nutrientes e à manutenção do habitat das espécies, assim como os demais serviços ambientais caracterizados. Esta situação equivale a dizer que o solo "foi removido" do local, havendo a necessidade de reposição de seus nutrientes e das condições de suporte originais. Assim, esta premissa é análoga à situação de erosão do solo.

\subsubsection{Serviços ambientais hídricos}

Segundo Fidalgo et al. (2017), um dos primeiros trabalhos de valoração dos serviços ambientais de provisão e regulação dos recursos hídricos foi desenvolvido no Vale do Rio Cauca, Colômbia, na década de 1990. O projeto objetivou garantir o fornecimento de água para os agricultores (principais consumidores deste recurso na região, que utilizavam até $86 \%$ da água da bacia para irrigação), através da compensação dos responsáveis pela preservação do ciclo da água. Segundo este mesmo autor, no Brasil, o pagamento por serviços ambientais hídricos iniciou-se de forma significativa na década de 2000, através da criação do Programa Produtor de Água, da Agência Nacional de Águas - ANA.

Em geral, os trabalhos técnicos e científicos buscam valorar a manutenção das condições normais de uma bacia hidrográfica (DE GROOT et al., 2002), sejam elas em relação ao volume de água, sua qualidade, meio de transporte ou lazer. Para tanto, considera-se a importância do solo superficial, da água subterrânea e da preservação da vegetação no ciclo hidrogeológico.

Entretanto, segundo Puga et al. (2015), há uma omissão quanto à perspectiva ecológica das águas subterrâneas e suas interações com os serviços ambientais, apesar de sua elevada importância e de estar diretamente ligada a provisão dos recursos hídricos usufruídos pela população. Segundo Rebouças (1994), sua vulnerabilidade depende de fatores intrínsecos (características naturais físico-químicas) e antrópicos (à carga poluente que o meio está exposto), sob influência da sazonalidade climática local. 
A interação da água subterrânea com a superficial contribui para: 1- produção e consumo, com o uso direto através dos poços; 2- provisão e suporte dos recursos hídricos, suportando a vazão das águas superficiais, através das contínuas descargas para os corpos d'água; 3- regulação da qualidade, através da filtração ou diluição dos contaminantes; 4- manutenção do recurso hídrico, através do armazenamento da água nos aquíferos e contínua liberação para os corpos de água superficiais nos períodos de seca (REBOUÇAS et al., 2006). Cabem acrescentar, ainda, as funções citadas por estes autores:

a) Estratégica: a maioria dos grandes centros urbanos sofre com a pouca oferta de água em relação à demanda, e, as águas subterrâneas complementam-se como alternativa para suprir a demanda em regiões de difícil distribuição pelas empresas de saneamento ou, ainda, em momento de crise de abastecimento.

b) Energética ou recreacional: utilização das águas termais como fonte de energia direta ou indireta ou ainda por diversas atividades recreacionais.

\subsubsection{Serviços culturais ou socioculturais}

Os serviços culturais consideram que as percepções sociais apresentam grande influência na importância dos serviços ambientais e, por consequência, nos valores a eles atribuídos (DE GROOT et al., 2002). Segundo MEA (2003), os métodos de valoração dos serviços ambientais não conseguem capturar totalmente o seu valor, pois, para muitas pessoas, a percepção do meio é intrínseca à questões éticas, religiosas e históricas de uma pessoa.

Segundo Andrade (2010) os serviços culturais podem ser valorados através de processos participativos da comunidade, com entrevistas e avaliações. O método resulta em um valor médio representativo para a região avaliada, podendo ser consequência de uma deliberação pública e aberta. Entretanto, há metodologia baseada em opiniões individuais, como a que ordena a importância e, consequente valor, dos serviços ambientais baseada nas preferências de indivíduos de um determinado grupo (PLIENINGER, T., 2013 e CALVET-MIR et al., 2012). 
Entretanto, para a aplicação de ambas as metodologias há a necessidade de uma pesquisa ampla e complexa, que apresentará valores variáveis no tempo e no espaço, em função da região.

\subsection{INVESTIGAÇÃO DO DANO AMBIENTAL - ÁREA CONTAMINADA}

Posteriormente à caracterização do bem ambiental, deve-se caracterizar a contaminação e seu impacto no meio.

Usualmente, as áreas contaminadas não são identificados a olho nu, sendo notadas, na maioria das vezes, quando seus efeitos atingem as águas, o solo, a vegetação e, consequentemente, o homem, causando danos graves.

A aplicação de auditorias e investigações ambientais para a caracterização das áreas contaminadas são essenciais para seu gerenciamento. Tendo em vista que tais medidas acarretam custos para as empresas, os principais fatores que as obrigam a realizar os procedimentos necessários para o gerenciamento de passivos são:

a) Obrigações legais (Federal, Estadual, Municipal).

b) Políticas corporativas (Responsible Care, Balanços Contábeis).

c) Processo de fusão e aquisição.

d) Pressões de mercado (ISO 14.000, Selo Verde, Financiamento Verde, pressão da comunidade, etc.).

Cabe destacar que muitas empresas já perceberam que ações preventivas têm custos muito menores que das ações corretivas (recuperação de áreas).

Segundo a CETESB (2019), o Estado de São Paulo possuía, em Dezembro de 2018 (Quadro 4.1), 6.110 (seis mil, cento e dez) áreas contaminadas conhecidas, sendo que a maior fonte de contaminação são os postos de combustíveis (4.384 áreas, ou 71,75 \% do total), seguidos das atividades industriais (responsáveis por $18,95 \%$ das contaminações) 
Quadro 4.1 - Áreas contaminadas cadastradas no Estado de São Paulo (CETESB, 2019)

\begin{tabular}{|l|c|c|c|c|c|c|}
\hline \multicolumn{7}{|c|}{ Áreas Cadastradas no Estado de São Paulo - dezembro de 2018} \\
\hline \multirow{2}{*}{ Região } & Comercial & Industrial & Resíduos & $\begin{array}{c}\text { Postos de } \\
\text { combustiveis }\end{array}$ & $\begin{array}{c}\text { Acidentes/ } \\
\text { Desconhecidal } \\
\text { Agricultura }\end{array}$ & Total \\
\cline { 2 - 7 } & & & & & 13 & 2.224 \\
\hline São Paulo & 124 & 421 & 58 & 1.608 & 13 & 1.073 \\
\hline RMSP - outros & 57 & 295 & 37 & 671 & 22 & 2.128 \\
\hline Interior & 98 & 328 & 70 & 1.610 & 4 & 389 \\
\hline Litoral & 33 & 47 & 26 & 279 & 2 & 296 \\
\hline Vale do Paraíba & 5 & 67 & 6 & 216 & 54 & 6.110 \\
\hline Total & 317 & 1.158 & 197 & 4.384 & & \\
\hline
\end{tabular}

Como, inicialmente, houve a avaliação ambiental dos postos devido à exigência para a obtenção ou renovação da licença de operação e da obrigatoriedade quando da troca dos tanques de armazenamentos de combustíveis subterrâneos (SASC), espera-se que a quantidade de áreas industriais conhecidas aumente no futuro próximo, contribuindo para o crescente número de áreas contaminadas cadastradas.

Tal percepção é descrita por Amicci (2010), que demonstrou que a percepção do mercado onde o alto percentual de postos de gasolina no cadastro da CETESB, em relação as demais classes de áreas contaminadas, está associada a publicação da Resolução CONAMA 273/2000. Em seu trabalho, a autora indica que haverá uma tendência de queda deste percentual relativo.

Entretanto, já no ano de 2000, a CETESB tinha publicado a Decisão de Diretoria 023/00/C/E, apresentando, pela primeira vez, os procedimentos para o gerenciamento de áreas contaminadas (GAC), juntamente com o Manual de Gerenciamento de Áreas Contaminadas, definindo as ações para as ocorrências (CETESB, 2001). Em 2007, os procedimentos de gerenciamento de áreas contaminadas foram revisados através da DD 103/2007/C/E.

A metodologia descrita no Manual de Gerenciamento de Áreas Contaminadas da CETESB definiu dois grandes processos de investigação (identificação e reabilitação de áreas contaminadas - Figura 4.2), que são realizados através de etapas sequenciais de estudos, onde a informação obtida em cada etapa é a base para a execução da etapa posterior. 


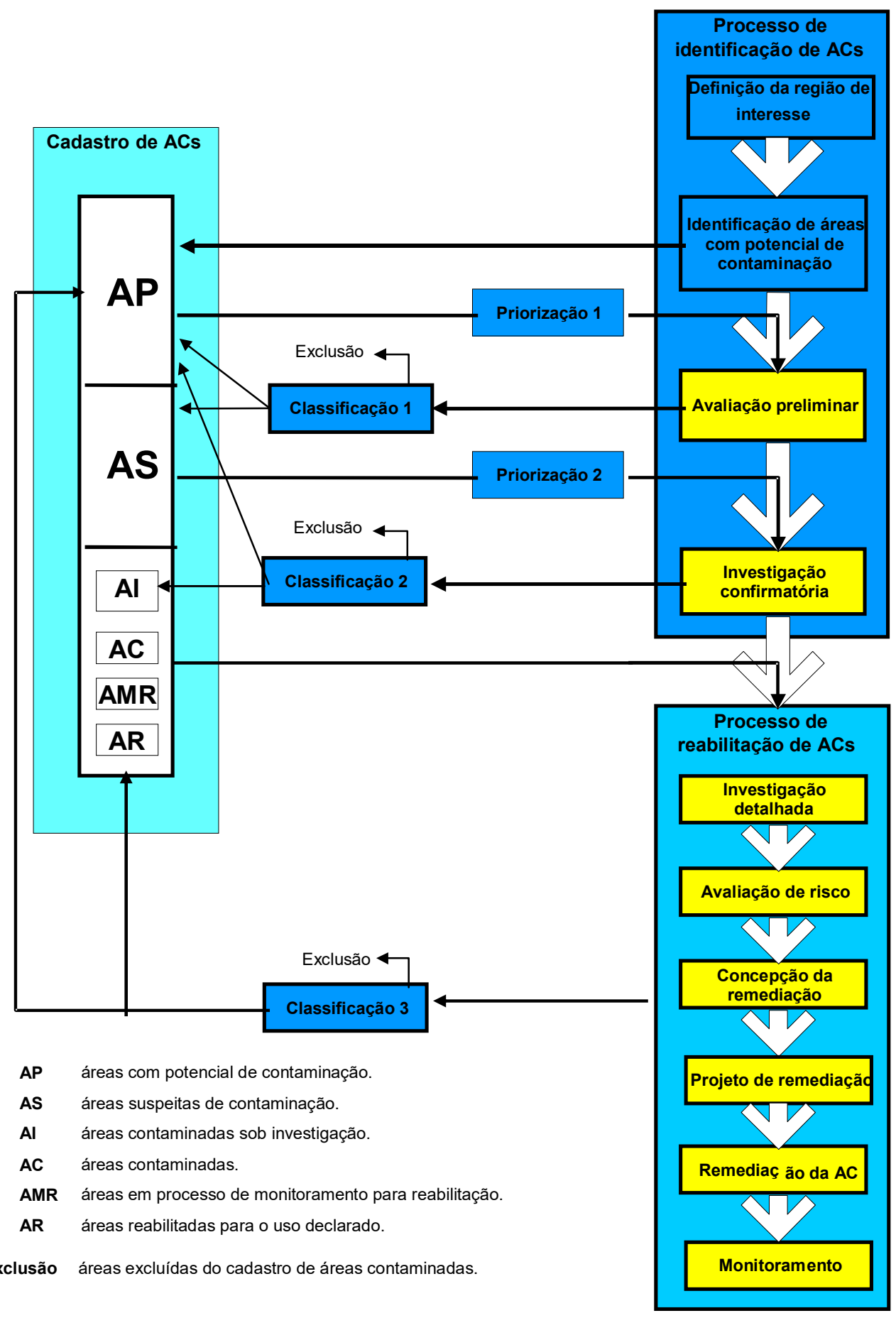

Figura 4.2 - Fluxograma de atividades no gerenciamento de áreas contaminadas (CETESB, 2016) 
A primeira etapa a cargo do responsável legal da área é a Avaliação Preliminar (AvP), que tem por objetivo identificar e/ou confirmar evidências das condições ambientais da área de interesse quanto à potencial existência de passivo ambiental (contaminação da qualidade de solo e / ou água subterrânea), sem, no entanto, realizar amostragens específicas. Com a identificação dos indícios, é efetuada uma Investigação Confirmatória (IC) , de forma a confirmar a ocorrência da área contaminada através da comparação de resultados analíticos de amostras coletadas na área com os Valores Orientadores do Estado de São Paulo, atualizados de tempos em tempos e publicados no Diário Oficial do Estado de São Paulo.

Cabe destacar que a estratégia de execução da IC é efetuada conforme plano de investigação proposto na AP, elaborado em função da disponibilidade e qualidade dos dados levantados, tendo por base o Modelo Conceitual Ambiental (MCA-1) e os contaminantes potenciais ou Substâncias Químicas de Interesse (SQI). O modelo deve ser classificado em:

- $\quad$ MCA-1A - Quando as fontes de contaminação foram identificadas e localizadas.

- MCA-1B - Existem dúvidas caracterizadas quanto às fontes de contaminação e suas localizações.

- MCA-1C - Quando não há informações sobre as fontes de contaminação e suas localizações.

Caso o resultado das análises das amostras coletadas demonstrem que as concentrações das substâncias encontram-se acima do valor de intervenção definido pelos Valores Orientadores, a área será considerada como Área Contaminada sob Investigação (CETESB, 2017), indicando a necessidade da continuidade das investigações, através do desenvolvimento das etapas subsequentes: Investigação Detalhada, seguida da Avaliação de Risco, do Plano de Intervenção e, caso necessário, da remediação, com posterior monitoramento para o encerramento. 
A Investigação Detalhada (ID), tendo por base o desenvolvimento planejado de sondagens, amostragens, ensaios e análises do sistema hidrogeológico da área, deve caracterizar a ocorrência dos contaminantes (SQI), sua massa e dinâmica no meio, assim como os diversos cenários em que os mesmos são expostos para os receptores, neste caso, o homem. Com o conhecimento adquirido na ID, é desenvolvida uma Análise de Risco Toxicológico (ARtx) que caracteriza o risco associado para os contaminantes frente à situação atual de uso ou um uso pretendido futuro. Os riscos devem estar dentro da faixa legal e aceitável, conforme legislação. Caso contrário, os mesmos devem ser minimizados e gerenciados. Para seu gerenciamento, são calculadas e definidas as Concentrações Máximas Aceitáveis (CMA) para a área e desenvolvido um plano de ação para a obtenção das CMA, consolidados em um Plano de Intervenção (PI).

O PI define as diretrizes de um possível processo de controle ou eliminação das fontes de contaminação, bem como um descritivo das medidas de intervenção (remediação) consideradas técnica e economicamente viáveis, com cronograma de implantação e programa de monitoramento das medidas propostas.

Ao fim do período de monitoramento, confirmada a manutenção das concentrações dos contaminantes abaixo das metas de remediação, a área será classificada como Área Reabilitada para o uso declarado (AR). Entretanto, após a declaração de reabilitação da área, esta não apresenta a mesma qualidade ambiental que antes do impacto tratado (contaminação), e sim, apenas, qualidade suficiente para o uso declarado, podendo restar passivos residuais com risco aceitável e restrições ao uso, decorrentes da permanência de contaminantes remanescentes no solo e água subterrânea.

Considerando a soma dos prazos médios de desenvolvimento de cada etapa de Gerenciamento de Áreas Contaminadas (GAC) apresentado pelo IPT (2018), são necessários quarenta e quatro meses (pouco menos de quatro anos) para o desenvolvimento das etapas do GAC conforme apresentado na Tabela 4.2. Estes prazos são semelhantes aos apresentados por Marcelino (2016) (Tabela 4.2b), mas o trabalho do IPT não considera o prazo existente entre as etapas, necessário para o entendimento do relatório pelo responsável legal, conscientização da necessidade do desenvolvimento da etapa subsequente e provisão de recursos, bem como o processo de contratação. 
Considerando que a legislação do estado de São Paulo estabelece um prazo máximo de 90 (noventa) dias entre uma etapa e a seguinte, ter-se-ia um acréscimo potencial de doze meses ao cronograma, sem contar que, usualmente, as empresas possuem dificuldades de planejamento financeiro e solicitam prorrogação de prazos para o início dos trabalhos subsequentes. Não se têm estudos, tampouco, sobre as prorrogações dos prazos para o desenvolvimento da ID, que, frente a impossibilidade de visualização direta das condições do subsolo, é um processo que avança com cautela, conforme são obtidos e analisados os resultados, de forma a minimizar recursos. Desta forma, o processo da ID(investigação, análise e decisão) é cíclico e ocorre quantas vezes forem necessárias para se atingir os objetivos estabelecidos pela DD 38/CETESB de 2017.

Tabela 4.2a - Prazos das etapas de gerenciamento de área contaminada (adaptado pelo autor de IPT, 2018)

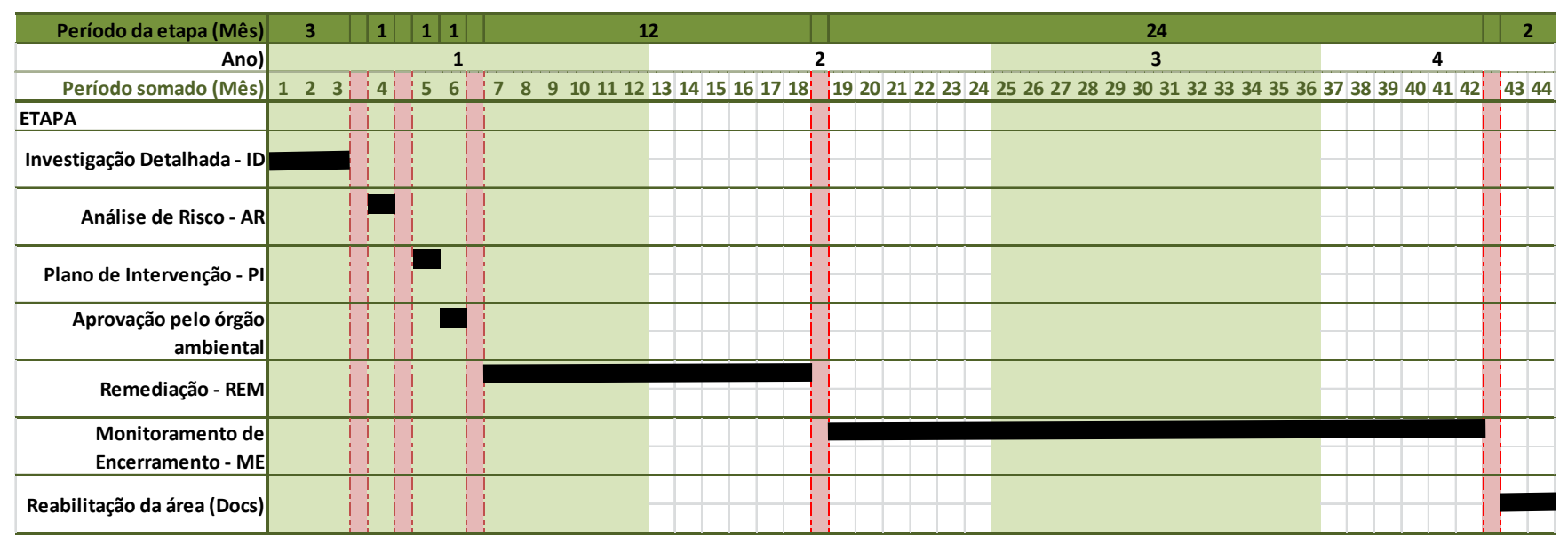

Cabe destacar, ainda, que a reabilitação da área somente é emitida após ser evidenciada a execução de todas as ações de gerenciamento dos riscos aprovadas no PI e, muitas delas, somente são executadas após a conclusão da remediação.

Assim, para as ações de gerenciamento de áreas contaminadas são necessários mais de quatro anos, podendo chegar até mais de dez anos (MARCELINO, 2016). Entretanto, apenas quando da emissão do PI, que somente ocorre após o segundo ano de investigações (no mínimo), é que são definidos os custos para as ações de remediação. Inexistem metodologias ou ferramentas para estimar os custos associados ao dano ambiental de áreas contaminadas, muito menos, a partir da identificação da ocorrência do passivo. 
Tabela 4.2b - Prazos das etapas de gerenciamento de área contaminada (MARCELINO, 2016)

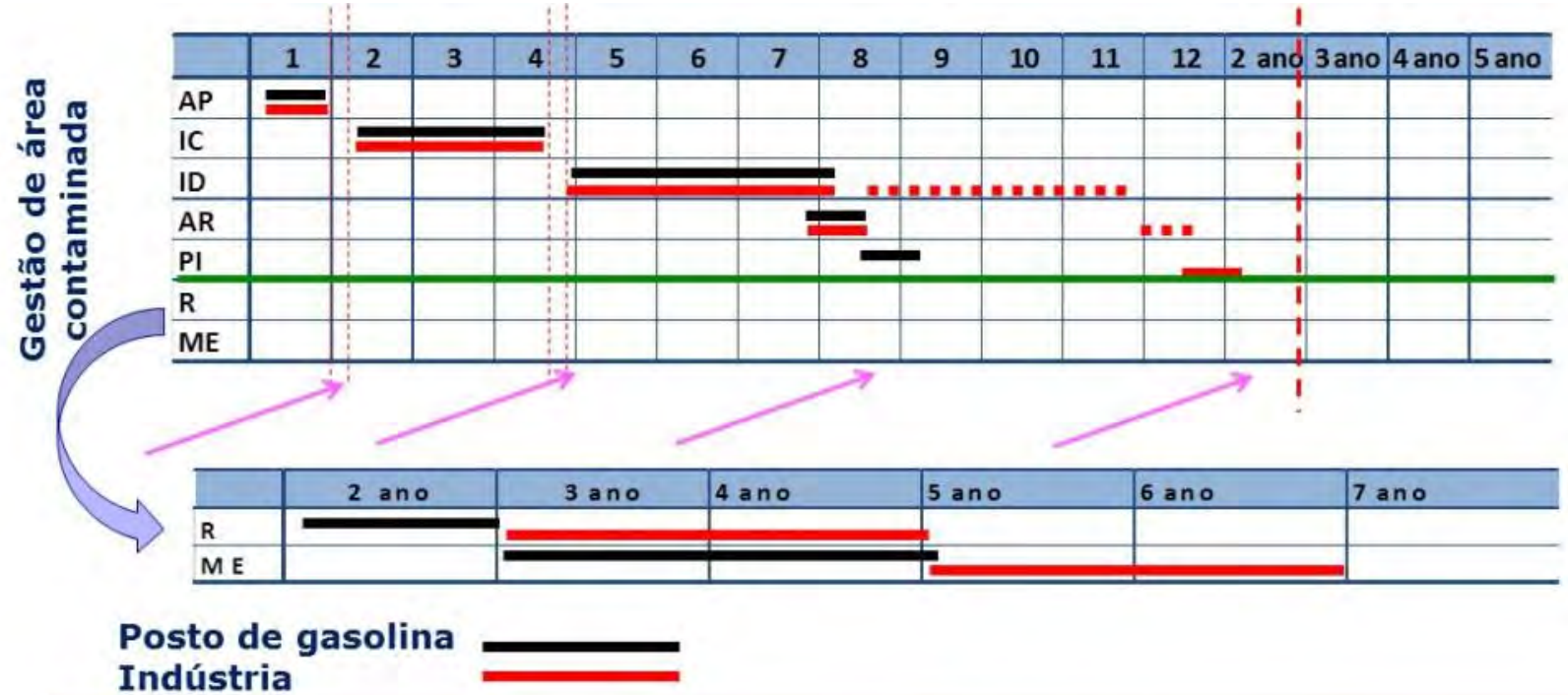

Posto de gasolina $(\mathrm{GAC})=4$ a 5 anos; $\mathbf{R}+\mathrm{ME}=\mathbf{3}$ a $\mathbf{4}$ anos.

Indústria (GAC) $\quad=5$ a 7 anos, $R+M E=4$ a 5 anos (pode ser $>10$ anos)

Assim, todas as atividades de gerenciamento de áreas contaminadas são iniciadas sem prévia estimativa do investimento necessário, dificultando o planejamento financeiro da empresa responsável pela área, aumentando os riscos de insucesso do projeto e da própria sobrevivência do empreendimento.

\subsection{O IMPACTO AMBIENTAL - A OCORRÊNCIA DA CONTAMINAÇÃO POR COMBUSTÍVEIS FÓSSEIS}

A dependência humana dos combustíveis fósseis e seus derivados como fonte de energia (e o seu uso de forma ampla, tanto nos grandes centros urbanos como no meio rural), tem favorecido, através de vazamentos, acidentes ou outros fatores, a ocorrência de danos ambientais associados à contaminação do solo e água subterrânea. Dos compostos presentes na gasolina, os mais prejudiciais à saúde humana e ao meio ambiente, destacam-se os hidrocarbonetos aromáticos Benzeno, Tolueno, Etilbenzeno e os isômeros do Xileno, conhecidos como BTEX.

Existem, essencialmente, três aspectos gerais pelos quais o imóvel pode ser afetado pela contaminação (NZRPGN, 1995):

a) Contaminantes existentes dentro do próprio terreno. 
b) Água contaminada, que pode ser estática ou ter migrado para fora do local, sob ou sobre o piso.

c) $\mathrm{O}$ ar, por gases contaminados provenientes dos contaminantes.

Considerando que São Paulo possui 10,4 mil postos (28 \%, do total de postos de combustíveis existentes no Brasil - 38,5 mil) (ANP, 2015) e a hipótese que todos os postos já tiveram sua área investigada, em conformidade com as exigências do licenciamento em vigência (Resolução CONAMA n 273/2000), 42,15 \% dos postos de gasolina apresentam problemas de área contaminada em2018.

Fatorelli (2005), indica que diferentes fatores influenciam no comportamento dos derivados de petróleo no solo, entre eles, destacam-se: características físicas do solo, físico-química dos minerais constituintes do solo, quantidade de matéria orgânica e fatores ambientais (temperatura e precipitação). Cabe destacar, entretanto, que, a adição do etanol nos combustíveis no Brasil, favorece a contaminação da água subterrânea, devido ao efeito de co-solvência.

Os combustíveis derivados de petróleo podem se particionar em cinco fases distintas em subsuperfície (USEPA, 1996):

$\checkmark$ Vapor: acumulado nos interstícios do solo ou emanado na superfície do terreno.

$\checkmark$ Retida: produto presente na superfície das partículas sólidas dos grãos minerais do solo.

$\checkmark$ Residual: produto puro acumulado nos vazios (poros) do solo, que não apresenta mobilidade no meio poroso.

$\checkmark$ Fase livre: produto puro com mobilidade no meio poroso.

$\checkmark$ Dissolvida: dissolvido na água subterrânea.

De uma forma geral, quando da ocorrência de um vazamento (em superfície ou em subsuperfície), os combustíveis infiltram-se no solo não saturado e, por forças gravitacionais e capilares, iniciam um movimento descendente com velocidade e direção variável em função das características físicas do solo e do relevo que condicionam a condutividade hidráulica, até chegar à franja capilar, zona de contato com a água subterrânea. 
A partição dos combustíveis em suas fases ocorrem de maneira dinâmica e irregular, e, assim, as quantidades podem variar tanto por mudança de fase quanto decorrente a biodegradação, o que dificulta a quantificação da massa de combustível no subsolo (LAGREGA, 1994; FERREIRA et al., 2000). A fase vapor pode apresentar um deslocamento 10.000 vezes maior que o fluxo do contaminante na fase dissolvida (USEPA, 1991).

De uma maneira simplista, no processo inicial de descida na zona não saturada, o combustível terá uma fase residual e outra, retida pelo solo, originando a fração de solo contaminado. Ocorrerá, também, a fase vapor originada por seus compostos mais leves parcialmente volatilizados. O vapor, uma vez originado, apresenta tendência ascendente para a superfície do terreno ou se acumulará nos interstícios do solo, condicionado pelas características do mesmo e do próprio composto volatilizado.

Uma vez que os combustíveis atingem a água subterrânea, na zona saturada, começam se dissolver na água e, por serem constituídos por compostos menos densos que a água, em função da concentração e volume inicial que atinge a água subterrânea, podem gerar duas fases distintas: fase livre (LNAPL - Light Non Aqueous Phase Liquids) e dissolvida. Estas, por sua vez, continuam a gerar a fase vapor. Ambas as fases apresentam mobilidade, sendo suas dinâmicas definidas pelo meio que percolam (características físicas do solo), volume e características físico-químicas do próprio contaminante e condições de fluxo da água subterrânea.

Segundo Oliveira (2016), os principais compostos contaminantes da gasolina sofrem atenuação natural e, usualmente, não originam plumas de fase dissolvida maiores que 150 a 200 m, a partir da fonte. Entretanto, a presença do etanol na gasolina brasileira, um co-solvente miscível tanto na água subterrânea quanto na gasolina, possibilita a ocorrência de plumas com maiores concentrações de BTEX que o produto puro. Assim, no Brasil, as distâncias percorridas pelos combustíveis na zona saturada, deve ser melhor avaliada.

A grosso modo, a distância que o contaminante percorre no subsolo a partir do ponto de infiltração (área fonte), dependerá do tempo disponível pelo mesmo no sistema hidrogeológico, da facilidade de sua percolação nomeio (condutividade hidráulica) e das interações físico-química e biológicas diversas entre o contaminante e o próprio meio. Estas últimas, de uma maneira geral, tendem e limitar o alcance do deslocamento do composto, atuando em sua velocidade e em sua presença no meio. 
A Figura 4.3 ilustra a dinâmica da contaminação por combustível no subsolo.

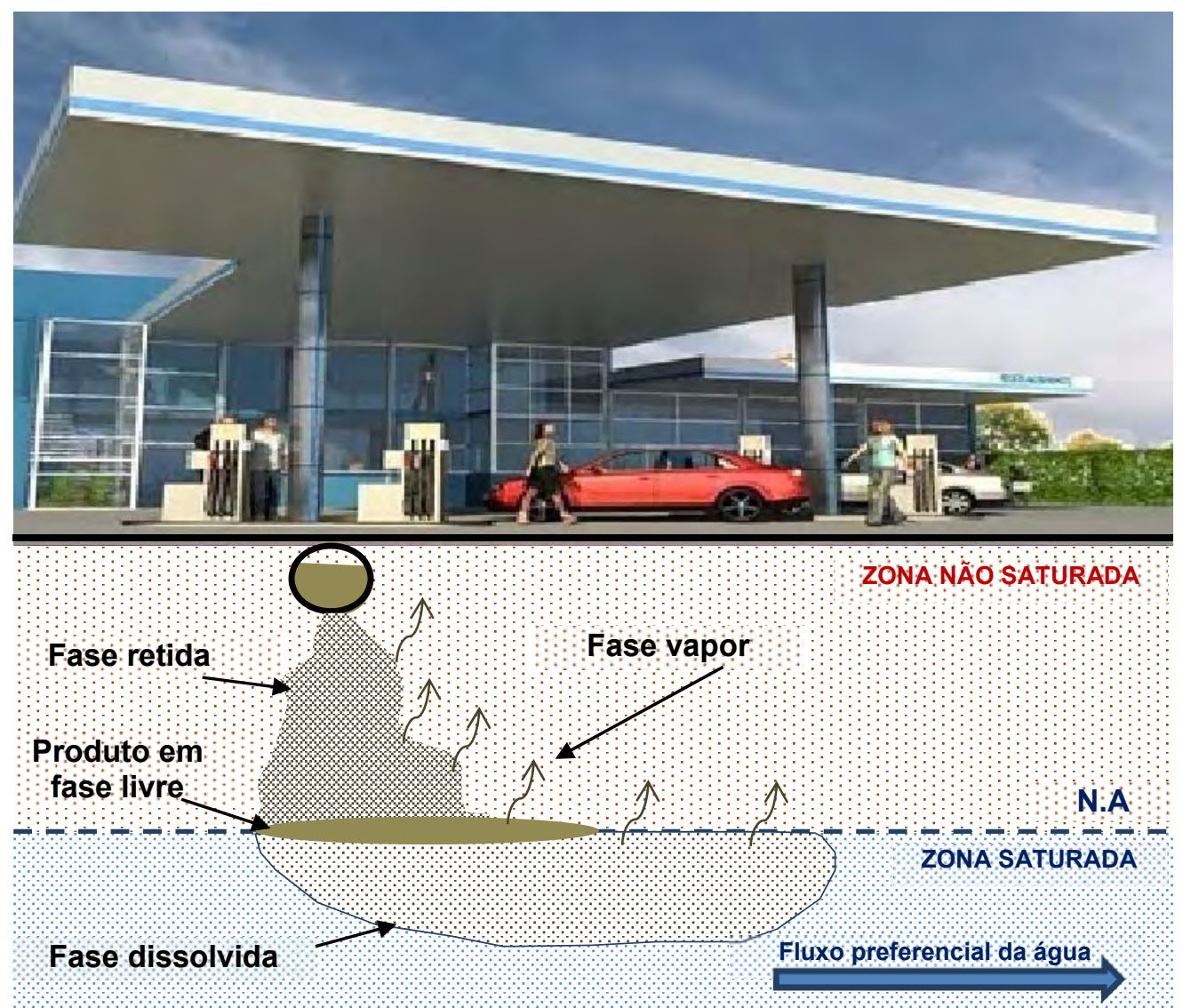

Figura 4.3 - Principais elementos da ocorrência de área contaminada por combustíveis no subsolo (ilustração do autor)

\subsection{REPARAÇÃO DO DANO}

Com a caracterização da contaminação e do risco associado, é elaborado o Plano de Intervenção, definindo-se as ações de remediação ou reparação do dano ambiental, conforme preconiza o Art. $23^{\circ}$ da Lei 13.577/09 (SÃO PAULO, 2009a).

O processo de remediação é monitorado até atingir os objetivos de qualidade com base no risco e uso declarado. Após a obtenção dos níveis de qualidade com base no risco, a área passa a ser monitorada para a confirmação da manutenção dos parâmetros de referência, em quatro campanhas semestrais. Com a comprovação da manutenção dos níveis de qualidade, a área é liberada para o uso declarado, conforme condições definidas no Plano de Intervenção (PI) e reclassificada como Área Reabilitada para o Uso Declarado (AR). 
Entretanto, como dito anteriormente, como a reparação tem como objetivo a reconstituição do meio para um padrão de qualidade que não ofereça risco à saúde, usualmente, mantém níveis de contaminação (passivo residual) que, apesar de não oferecer riscos (conforme uso declarado da área atual ou futuro), mantém uma degradação em relação à qualidade antes da contaminação. Este passivo é objeto de discussão jurídica quanto a uma possível compensação pelo dano, considerado irreversível.

A evolução das concentrações que caracterizam o impacto ambiental em função das ações do Gerenciamento de Área Contaminada (GAC) é apresentada na forma gráfica por Bertolo et al. (2019), considerando o tempo e as concentrações envolvidas (Figura 4.4). O gráfico apresentado pelo autor ilustra bem que a remediação termina antes da obtenção da potabilidade e que, assim, ingressa no campo da reparação. Destaca, no entanto, que as complexidades hidrogeológicas fazem o gráfico variar, chegando a ocorrer, algumas vezes, uma concentração pós remediação menor que a da potabilidade.

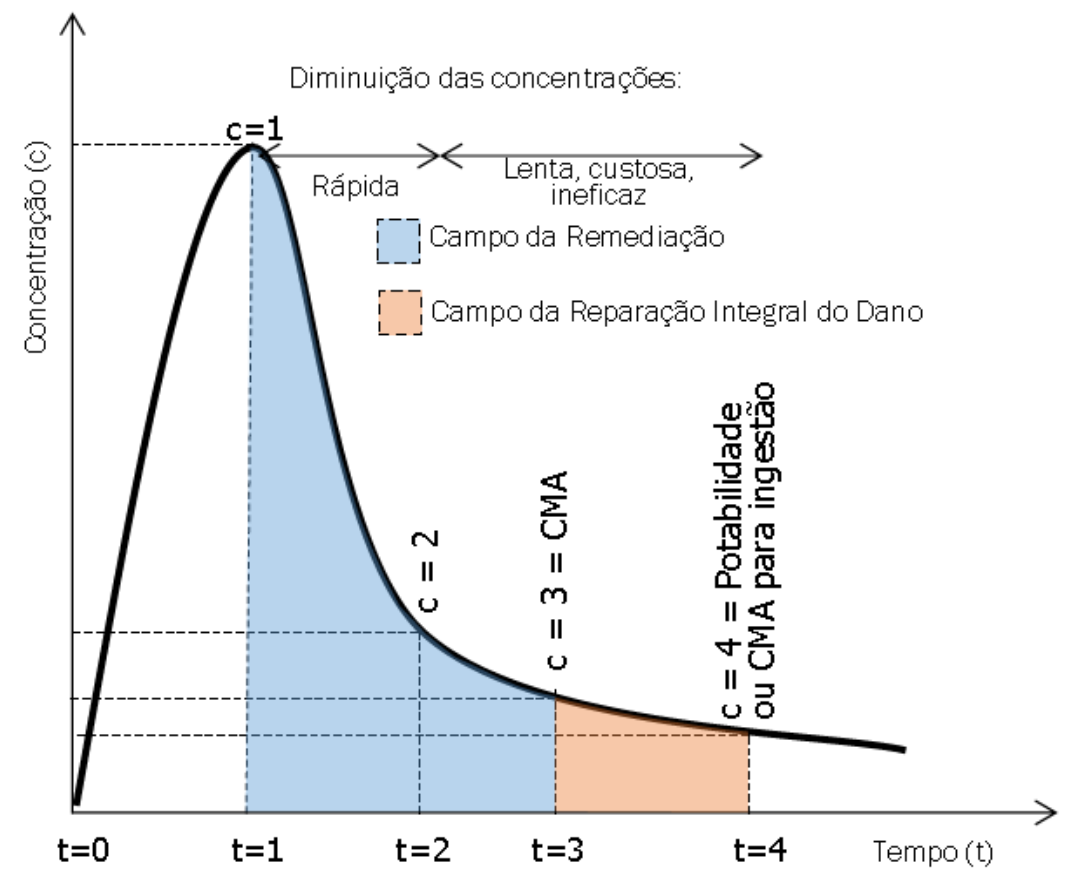

$t_{0}$ a $t_{1}=$ contaminação da área; $t_{1}$ a $33=$ remediação; $t_{3}$ a $t_{4}=$ não potável e sem risco e reabilitada (legenda inserida pelo autor dessa tese)

Figura 4.4 - Comportamento genérico das concentrações de contaminantes na água subterrânea antes, durante e após a execução de medidas de remediação (BERTOLO et al., 2019) 
O trabalho indica que, não raro, o tempo necessário para que a concentração varie de $c=3$ (MRBR) para $c=4$ (potabilidade) é longo devido as complexidades hidrogeológicas e às concentrações envolvidas, tornando as ações de remediação antieconômicas.

\subsubsection{Reparação do dano ambiental reversível - Remediação ambiental}

A remediação de uma área contaminada consiste na aplicação de uma ou mais técnicas de controle e diminuição das concentrações e da massa dos contaminantes caracterizados na área, conforme objetivos definidos em análise prévia de risco à saúde humana, considerando o uso atual e futuro da área.

As técnicas de remediação podem ser aplicadas no local (in situ), com a remoção do solo ou água contaminada e tratamento em instalações especializadas, bem como, fora do local (ex situ), efetuando o processo na área impactada, sem a remoção dos materiais. Existe uma tendência de utilização das tecnologias de remediação in situ, em detrimento das ex situ, pois: a) usualmente, nas grandes cidades, ocorrem edificações sobre a área contaminada, dificultando e induzindo custos adicionais para a remoção do material a ser tratado; b) o transporte do material contaminado implica em riscos e custos adicionais associados e, c) o material removido para ser tratado é, inicialmente, classificado como resíduo, e, naturalmente, o material resultante do tratamento será classificado como resíduo também, implicando em novas ações e custos associados para sua disposição final.

A remediação da área contaminada somente ocorre sobre o dano reversível, onde as condições ambientais negativas são eliminadas. Entretanto, esta é planejada e executada de forma a obter a diminuição até a Máxima Concentração Aceitável (CMA), calculada com base no risco à saúde humana, em conformidade com a legislação do Estado de São Paulo.

Com a reparação do dano reversível, obtém-se, assim, a conformidade legal no gerenciamento de área contaminada. A alteração ambiental que permanecerá após a remediação, em relação à qualidade inicial do meio antes do impacto ambiental, aqui, denominamos de dano ambiental irreversível. 
A técnica de remediação a ser aplicada (ou mais de uma) é definida quando da elaboração do Plano de Intervenção (PI) para a área contaminada em questão, e considerará, entre outros aspectos:

$\checkmark$ Características físicas do local. $\quad \checkmark$ Viabilidade técnica e econômica.

$\checkmark$ Tipo e características da ocorrência do $\checkmark$ Custos envolvidos. contaminante.

$\checkmark$ Riscos associados e tempo disponível.

Segundo a CETESB (2019), das 6.110 (seis mil cento e dez) áreas contaminadas, 1453 (um mil, quatrocentos e cinquenta e três) $(23,78$ \% do total) já obtiveram a reabilitação para uso declarado, após ações de intervenção. A Figura 4.5 ilustra a distribuição das diversas técnicas de remediação de áreas contaminadas aplicadas no Estado de São Paulo até Dez/18.

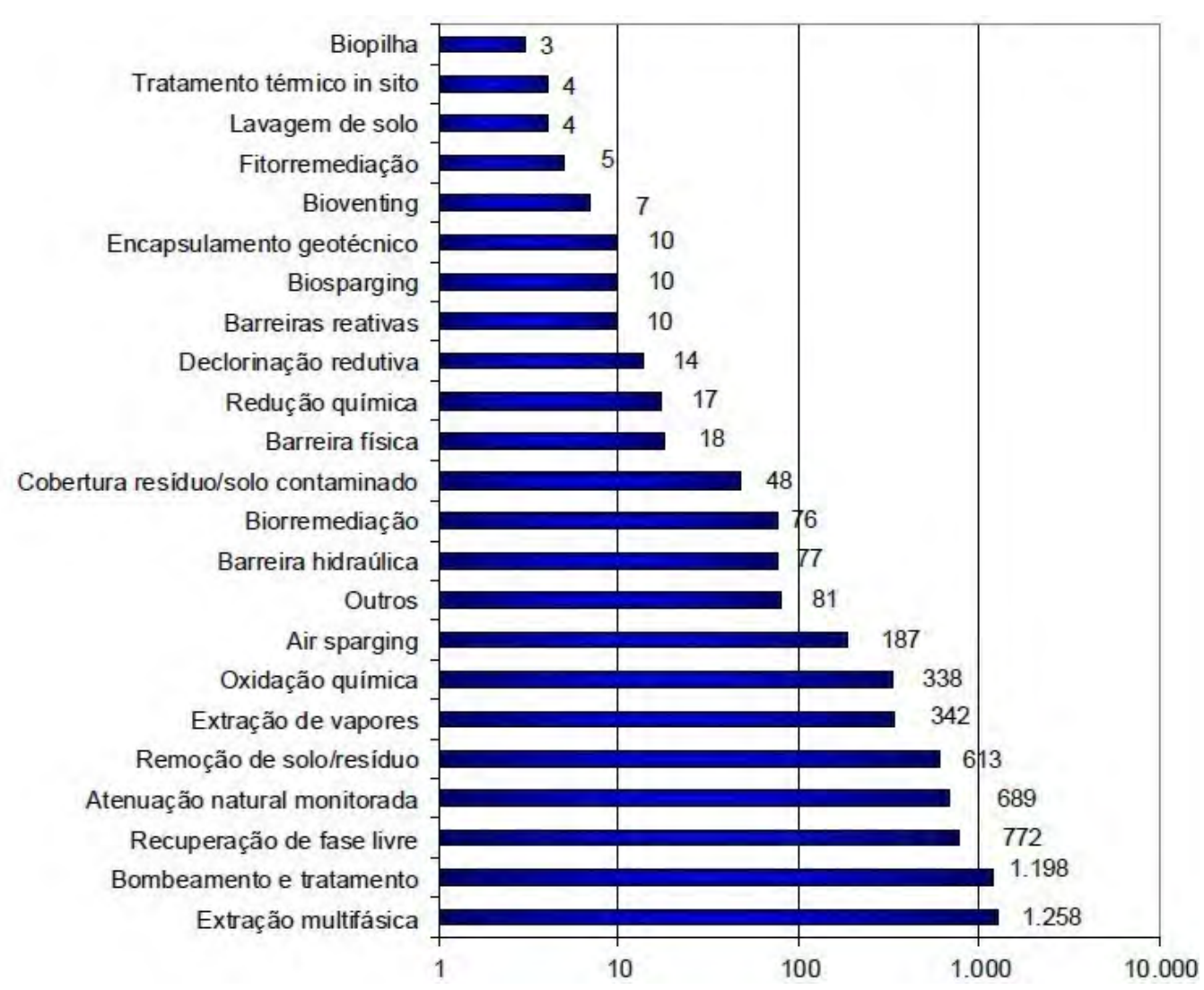

Figura 4.5 - Técnicas de remediação aplicadas no Estado de São Paulo até Dezembro 2018 (CETESB, 2019). 
Uma análise simples dos números apresentados pela CETESB (2019) sobre as tecnologias de remediação aplicadas até dezembro de 2017 (Tabela 4.3) indica que em $94,6 \%$ dos casos, são utilizadas 8 (oito) das tecnologias cadastradas pela CETESB. Este índice, provavelmente, ocorre por haver a predominância de áreas contaminadas por combustíveis derivados de petróleo cadastradas.

Das remediações aplicadas, a grosso modo, 19,5 \% são tecnologias com ênfase na remediação da zona não saturada e, $80,5 \%$, da zona saturada.

Tabela 4.3 - Análise das principais tecnologias de remediação aplicadas no Estado de São Paulo até dezembro de 2018 (elaborado pelo autor).

\begin{tabular}{|c|c|c|c|}
\hline TECNOLOGIA & SATURADA & NÃO SATURADA & $\%$ \\
\hline Biopilha & & 3 & $0.05 \%$ \\
\hline Tratamento térmico in situ & & 4 & $0.07 \%$ \\
\hline Lavagem de solo & & 4 & $0.07 \%$ \\
\hline Fitorremediação & & 5 & $0.09 \%$ \\
\hline Bioventing & & 7 & $0.12 \%$ \\
\hline Encapsulamento geotécnico & & 10 & $0.18 \%$ \\
\hline Biosparging & 10 & & $0.18 \%$ \\
\hline Barreira reativa & 10 & & $0.18 \%$ \\
\hline Declorinação redutiva & 14 & & $0.25 \%$ \\
\hline Redução química & 17 & & $0.30 \%$ \\
\hline Barreira física & 18 & & $0.32 \%$ \\
\hline Cobertura de solo contaminado & & 48 & $0.84 \%$ \\
\hline Biorremediação & & 77 & $1.35 \%$ \\
\hline Outros & \multicolumn{2}{|r|}{81} & $1.42 \%$ \\
\hline Air sparging & 187 & & $3.28 \%$ \\
\hline Oxidação química & 338 & & $5.92 \%$ \\
\hline Extração de vapores & & 342 & $5.99 \%$ \\
\hline Remoção de solo & & 613 & $10.74 \%$ \\
\hline Atenuação natural & 689 & & $12.08 \%$ \\
\hline Recuperação de fase livre & 772 & & $13.53 \%$ \\
\hline Bombemento e tratamento & 1198 & & $21.00 \%$ \\
\hline Extração multifásica & 1258 & & $22.05 \%$ \\
\hline N. tecnologias solo / água subterrânea & $\begin{array}{c}4592 \\
80.49 \% \\
\end{array}$ & $\begin{array}{c}1113 \\
19.51 \%\end{array}$ & $100.00 \%$ \\
\hline Total das tecnologias aplicadas & & 5705 & \\
\hline
\end{tabular}

Cabe destacar que a aplicação de técnicas de engenharia concomitantemente a remediação (seja ela através de uma ou mais técnica de remediação) auxiliam na maximização da eficiência e na minimização dos prazos do processo de remediação (PICCHI et al., 2009). Assim, a remediação de uma área pode ser através do uso de uma ou mais técnica de remediação, associada ou não a obras de engenharia. 
Por outro lado, Marker (2013), em seu trabalho desenvolvido no Projeto Integration, visando o melhoramento da coesão social e territorial na América Latina, sistematizou e adaptou uma metodologia de gestão pública aplicada na Europa, de saneamento ecológico, econômico e social de brownfields - áreas degradadas e contaminadas - para as regiões urbanas cinco cidades latino-americanas: São Paulo, Rio de Janeiro, Quito, Bogotá e Guadalajara.

Este projeto sugere uma metodologia de cadastro e investigação de áreas degradas (contaminadas ou não) nos grandes centros urbanos, visando o controle do risco e reabilitação para o uso pretendido dos brownfields. Apresenta, ainda, alguns casos de sucesso de reabilitação de áreas degradadas em São Paulo e que, apenas tendo por base uma Avaliação Preliminar e o Modelo Conceitual (ambiental) pode-se, teoricamente, definir-se um escopo de intervenção para a área.

Entretanto, a legislação do Estado de São Paulo indica que a Avaliação Preliminar apenas caracteriza uma área como suspeita de estar contaminada, havendo a necessidade de confirmação da anomalia ambiental através do desenvolvimento da Investigação Confirmatória. Com a confirmação da anomalia ambiental a área passa a ser Área Contaminada sob Investigação $(\mathrm{ACl})$, passando a haver a necessidade de uma Investigação Detalhada para a caracterizar a ocorrência desta anomalia que, ainda, pode ser considerado de origem natural ou não.

O trabalho publicado por Marker (2013) apresenta, ainda, um resumo de uma metodologia e planilha de prognóstico de custos de revitalização utilizada na Alemanha, indicando que a mesma ainda não está disponível para uso na América Latina. Esta metodologia estima, de maneira preliminar, o escopo e custos associados para:

$\checkmark$ A investigação e a quantificação da contaminação.

$\checkmark$ Eleição de medidas de intervenção e estimativas de custos associados para a revitalização da área degradada.

$\checkmark$ Eleição de metodologias de tratamento de solo e das águas subterrâneas e custos associados.

$\checkmark$ Estimativas de custos associados a demolição e desmobilização das antigas estruturas existentes nas áreas.

$\checkmark$ Custos associados a medidas de segurança ocupacional do trabalhador de obra. 
Segundo o mesmo autor, a planilha foi, desenvolvida no Projeto PROSIDE (Promoting Sustainable Inner Urban Development) na União Europeia, efetua prognósticos dos custos de recuperação de um terreno degradado/contaminado (site industrial / comercial desativado) baseado em custos médios de serviços executados na Alemanha.

\subsubsection{Remoção e tratamento do solo}

A mais rápida e eficiente técnica de tratamento do solo contaminado existente na zona não saturada consiste na escavação, remoção e destinação final do solo contaminado. Esta, usualmente, é aplicada para profundidades inferiores a 5,0 m, havendo a necessidade prévia de classificação e obtenção de autorizações legais pertinentes.

O solo final pode ser destinado para: a) aterro de resíduos perigosos; b) tratamento biológico ex-situ e posterior destinação em aterro para resíduos não perigosos; c) tratamento térmico (co-processamento, dessorção ou incineração).

\subsubsection{Recuperação de fase livre}

Quando o volume de produto infiltrado no subsolo é superior à capacidade de retenção do solo, ele se acumula de forma irregular na zona não saturada e, em especial, logo acima do nível freático, formando a fase livre de hidrocarbonetos.

Existem várias formas de recuperar a fase livre de hidrocarbonetos, muitas delas, sendo uma mistura de técnicas diferentes, como as descritas em itens subsequentes. Para fins de separação de tópico desta tese, entende-se recuperação de fase livre aquela efetuada sem a utilização de rebaixamentos da água induzidos por bombeamentos (descrita no item bombeamento e tratamento) ou recuperação simultânea do vapor, ou vapor e água. Os skimmers são equipamentos que possuem uma membrana hidrofóbica que permite a passagem do óleo para seu interior, sem, contudo, capturar a água. Estes, quando apenas permitem o ingresso e acumulo do óleo em seu interior, são passivos e, quando possuem um sistema de bombeamento (através da aplicação de pressão negativa), são denominados ativos. Ambos possuem baixa área de abrangência, efetuando a remoção limitada da fase livre. 


\subsubsection{Bombeamento e Tratamento (P\&T)}

A técnica do Bombeamento e Tratamento (Pump and Treat - P\&T) consiste na extração da água subterrânea contaminada através do bombeamento em poços projetados, com posterior tratamento dos produtos extraídos em superfície. Além de proporcionar o tratamento da água, a técnica, quando bem dimensionada, pode conter e controlar o fluxo dos contaminantes no subsolo, efetuando barreiras hidráulicas negativas e, quando da injeção da água tratada, barreiras positivas.

O P\&T ainda é a tecnologia mais utilizada na remediação de áreas contaminadas por hidrocarbonetos, em especial as que apresentam fase livre do produto contaminante (NOBRE \& NOBRE, 2008). Usualmente, esta tecnologia é ineficiente como tecnologia única, uma vez que os processos de transferência de massa do contaminante para a água subterrânea são muito lentos, havendo a necessidade de bombear e tratar grandes quantidades de água em períodos muito extensos (OLIVEIRA, 2008; MACKAY \& CHERRY, 1989).

Em geral, a tecnologia do P\&T utiliza-se de outras técnicas para a separação do produto com a água, para remover e tratar os produtos orgânicos ou inorgânicos bombeados, assim como a fase vapor (USEPA, 1996).

\subsubsection{Remediação Multifásica (MPE)}

O Sistema de Extração Multifásica ou MPE combina as técnicas de bioventilação e remoção de massa a vácuo, possibilitando a extração da fase livre, da fase vapor e da fase dissolvida, além de estimular processos de biodegradação natural na zona não saturada.

Por meio da aplicação do vácuo em poços de extração instalados na área a remediar, o MPE cria uma zona de influência de pressão negativa em toda a extensão da pluma de fase livre que visa "atrair" e extrair as fases livre, de vapor e a dissolvida dos contaminantes. 
A mistura bombeada é tratada de forma a separar a água do óleo, sendo a mesma tratada por filtros de carvão e posterior reinjeção no subsolo e, o óleo, armazenado para posterior destinação final. O vapor, tanto o extraído do subsolo quanto no processo de separação da água e óleo, é tratado em uma coluna de carvão ativado e disperso na atmosfera.

\subsubsection{Soil Vapor Extraction (SVE) e Air Sparging (ASp)}

A técnica do Soil Vapor Extraction (SVE) consiste na captação a vácuo e remoção dos vapores existentes na zona não saturada, para seu tratamento em superfície. Já o Air Sparging (ASp) é utilizada para maximizar a eficiência de outros sistemas de remediação, em especial o SVE, através de injeções de ar no subsolo, tanto na zona saturada como na não saturada. O ar injetado desloca-se tanto na horizontal como na vertical no subsolo, promovendo a remoção dos contaminantes por volatilização das partículas sorvidas no solo e ou dissolvidas na água para a fase de vapor, onde o gás pode vir a ser biodegradado ou removido por sistemas de extração de vapores.

Assim, usualmente a extração de vapores é efetuada através da atuação, em conjunto, do sistema SVE e do ASp, aumentando a eficiência da remoção dos contaminantes.

Para sua aplicação com eficiência, não deve haver heterogeneidade dos litotipos de e deve haver uma condutividade hidráulica média superior a $10^{-5} \mathrm{~cm} / \mathrm{s}$ e uma zona não saturada com espessura de 1,0 a 9,0 m (WILSON, 1995).Quando as técnicas são combinadas, apresenta alta eficiência para o tratamento de hidrocarbonetos na zona saturada rasa e não saturada (YANCHESKI, 1992)

\subsubsection{Oxidação Química - ISCO}

O procedimento de remediação de uma área impactada por meio de oxidação química, baseia-se na aplicação de substâncias químicas objetivando a transformação de moléculas indesejáveis em outras menos tóxicas, "para que estas possam ser assimiladas de modo mais harmonioso nos ciclos da natureza" (JARDIM \& CANELA, 2004). Apresenta a facilidade de poder ser aplicado no local, evitando os custos de remoção e reposição do solo e, assim, a tendência é de se utilizar esta tecnologia in situ (DYMINSKI, 2006), passando a ser denominada ISCO - Oxidação química in situ. 
O sistema ISCO promove reações de oxidação / redução com a ruptura sequencial de ligações moleculares dos compostos tóxicos, alterando, assim, suas propriedades, tornando-os menos nocivos ou inócuos à saúde.

\subsubsection{Atenuação Natural Monitorada (ANM)}

A Atenuação Natural Monitorada (ANM) é uma tecnologia de remediação passiva, que, através de indicadores físicos, químicos e biológicos previamente estudados e avaliados na área, indicam uma condição favorável para o processo de degradação natural dos compostos contaminantes, sem uma ação direta do homem (MOERI, 2004).

O processo de degradação é monitorado de forma a caracterizar a contínua e gradativa diminuição da massa, da concentração e da toxidade dos contaminantes, bem como de sua mobilidade no solo e água subterrânea.

4.5.1.9 Custos médios associados ao gerenciamento de área contaminada

As metodologias de investigação são padronizadas e normatizadas, havendo uma variação em relação aos quantitativos em função da ocorrência do contaminante. Assim, os custos associados são bastante homogêneos para o mercado de São Paulo, já bastante maduro para a investigação de áreas com ocorrência de combustíveis fósseis. Já as metodologias de remediação, apresentam custos de implantação e operação variados em função das características da área e dos contaminantes. Entretanto, para todas, é necessário um investimento inicial de projeto, englobando, muitas vezes, ensaios e testes piloto desenvolvidos durante a fase de PI, quando da eleição da melhor tecnologia a ser aplicada para a área.

O IPT (2018) apresentou os valores médios práticos no Estado de São Paulo para as diversas etapas de gerenciamento de áreas contaminadas, conforme apresentado na Tabela4.4. 
Tabela4.4 - Valores médios de mercado para as etapas de Gerenciamento de Áreas Contaminadas (IPT, 2018)

\begin{tabular}{|c|c|c|c|}
\hline ATIVIDADE & $\mathrm{R} \$$ (min) & & $\mathrm{R} \$$ (max) \\
\hline Investigação Detalhada - ID & $R \$ 250.000,00$ & a & $\mathrm{R} \$ 400.000,00$ \\
\hline Análise de Risco - AR & & & $\mathrm{R} \$ 2$ \\
\hline Plano de Intervenção - PI & $\mathrm{R} \$ 30.000,00$ & a & $R \$ 65.000,00$ \\
\hline Aprovação pelo órgão ambiental & $\mathrm{R} \$ 25.000,00$ & a & $R \$ 25.000,00$ \\
\hline Projeto básico de remediação & & & $R \$ 65.000,00$ \\
\hline
\end{tabular}

Uma vez que uma ou mais tecnologias de remediação são eleitas, o projeto de remediação é detalhado e implementado, passando a ser operado até a obtenção dos objetivos pré-definidos com base no risco. Dentre os custos de operação e manutenção das tecnologias de remediação, destacam-se: manutenção do sistema, insumos utilizados (oxidantes, carvão ativado, energia, ar comprimido, etc.), mão de obra especializada (e logística associada) e o monitoramento de eficiência e eficácia do processo.

A Tabela 4.5, apresenta custos médios das diversas tecnologias de remediação consideradas, conforme bibliografia consultada (BROWN, R., 1994; COHEN, et al 1997; EDSON, 2008; IPT, 2018; LUSVARGHI NETO, 2009; MARCELINO, 2016; NAVFAC, 2001; PICCHI, et al. 2009; USEPA, 1993 e 1996; YANCHESKI, 1992), com os valores convertidos para real na data da publicação e corrigidos pelo INCC (Índice Nacional da Construção Civil), conforme indicadores apresentados no Anexo I. 
Tabela 4.5 - Custos médios associados as tecnologias de remediação consideradas (consolidação do autor).

\begin{tabular}{|c|c|c|c|c|}
\hline \multicolumn{5}{|l|}{ METODOLOGIA } \\
\hline ZONA NÃO SATURADA & & & \multicolumn{2}{|l|}{$2018 *$} \\
\hline Remoção e destinação do solo & \$/m3/Ano & Ano & (R\$̧/Unid/Ano) & Unid \\
\hline PICCHI, A.R., et al. (2009, BR) & $\mathrm{R} \$ 300.83$ & 2009 & $\mathrm{R} \$ 486.72$ & m3 \\
\hline EDSON (2008, BR) & $R \$ 625.00$ & 2008 & $\mathrm{R} \$ 1,085.94$ & m3 \\
\hline FRTR (Iin IPT, 2018) (1996, USEPA) & USD 365.00 & 2016 & $R \$ 1,453.86$ & $\mathrm{~m} 3$ \\
\hline \multirow[t]{2}{*}{ MARCELINO $(2016, \mathrm{BR})$} & $\mathrm{R} \$ 555.82$ & 2016 & $\mathrm{R} \$ 634.63$ & m3 \\
\hline & & Média & $\mathrm{R} \$ 915.29$ & m3 \\
\hline Extração de vapor (NA<2,0m) & $\$ / \mathrm{m} 3 /$ Ano & & (R\$/Unid/Ano) & Unid \\
\hline USEPA (1993) & USD 86.50 & 1993 & $\mathrm{R} \$ 9.99$ & $\mathrm{~m} 2$ \\
\hline YANCHESKI, 1992 & USD 105.00 & 1992 & $\mathrm{R} \$ 12.13$ & $\mathrm{~m} 2$ \\
\hline FRTR (Iin IPT, 2018) (1996, USEPA) & USD 3.57 & 2016 & $\mathrm{R} \$ 13.57$ & $\mathrm{~m} 2$ \\
\hline \multirow[t]{2}{*}{ MARCELINO (2016, BR) } & $\mathrm{R} \$ 44.66$ & 2016 & $\mathrm{R} \$ 50.99$ & $\mathrm{~m} 2$ \\
\hline & & Média & $\mathrm{R} \$ 21.67$ & $\mathrm{~m} 2$ \\
\hline ZONA SATURADA (ou ambas) & & & 2018* & \\
\hline Air sparging & $\$ / \mathrm{m} 3 /$ Ano & Ano & (RS\$/Unid/Ano) & Unid \\
\hline NAVFAC, 2001 (EUA) & USD 750.00 & 2001 & $R \$ 4,220.10$ & $\mathrm{~m} 2$ \\
\hline BROWN, R. (1994) (CAN) & USD 750.00 & 1994 & $R \$ 1,574.82$ & $\mathrm{~m} 2$ \\
\hline EDSON, 2008 & $\mathrm{R} \$ 620.00$ & 2008 & $R \$ 1,077.25$ & $\mathrm{~m} 2$ \\
\hline FRTR (lin IPT, 2018) (1996, USEPA) & USD 447.32 & 2016 & $\mathrm{R} \$ 1,701.30$ & $\mathrm{~m} 2$ \\
\hline \multirow[t]{2}{*}{ MARCELINO $(2016, \mathrm{BR})$} & $\mathrm{R} \$ 535.93$ & 2016 & $\mathrm{R} \$ 611.92$ & $\mathrm{~m} 2$ \\
\hline & & Média & $\mathrm{R} \$ 1,837.08$ & $\mathrm{~m} 2$ \\
\hline Atenuação natural (in situ) & \$/m3/Ano & Ano & (R\$/Unid/Ano) & Unid \\
\hline EDSON, 2008 & $R \$ 475.00$ & 2008 & $\mathrm{R} \$ 825.31$ & $\mathrm{~m} 2$ \\
\hline FRTR (Iin IPT, 2018) (1996, USEPA) & USD $4,380.00$ & 2016 & $\mathrm{R} \$ 16,658.61$ & $\mathrm{~m} 2$ \\
\hline \multirow{2}{*}{ MARCELINO $(2016, \mathrm{BR})$} & $\mathrm{R} \$ 718.25$ & 2016 & $\mathrm{R} \$ 820.10$ & $\mathrm{~m} 2$ \\
\hline & & Média & $\mathrm{R} \$ \mathbf{8 2 2 . 7 1}$ & $\mathrm{m} 2$ \\
\hline Bombemento e tratamento & $\$ / \mathrm{m} 3 /$ Ano & Ano & (R\$/Unid/Ano) & Unid \\
\hline PICCHI, A.R., et al. (2009) (BR) & $\mathrm{R} \$ 720.00$ & 2009 & $\mathrm{R} \$ 1,164.89$ & m3 \\
\hline LUSVARGHI NETO (2009) & $\mathrm{R} \$ 12.63$ & 2009 & $\mathrm{R} \$ 20.43$ & m3 \\
\hline COHEN, et al (1997) & USD 27.00 & 1997 & $\mathrm{R} \$ 77.41$ & m3 \\
\hline \multirow{2}{*}{ MARCELINO $(2016, \mathrm{BR})$} & $\mathrm{R} \$ 76.43$ & 2016 & $\mathrm{R} \$ 87.27$ & $\mathrm{~m} 3$ \\
\hline & & Média & $\mathrm{R} \$ \mathbf{3 3 7 . 5 0}$ & m3 \\
\hline Extração multifásica & $\$ / m 3 /$ Ano & Ano & (R\$/Unid/Ano) & Unid \\
\hline EDSON, 2008 & $\mathrm{R} \$ 25.83$ & 2008 & $\mathrm{R} \$ 44.89$ & $\mathrm{~m} 2$ \\
\hline FRTR (lin IPT, 2018) (1996, USEPA) & USD 49.78 & 1997 & $\mathrm{R} \$ 189.32$ & $\mathrm{~m} 2$ \\
\hline \multirow[t]{2}{*}{ MARCELINO (2016, BR) } & $\mathrm{R} \$ 43.28$ & 2016 & $\mathrm{R} \$ 49.42$ & $\mathrm{~m} 2$ \\
\hline & & Média & $\mathrm{R} \$ 94.54$ & $\mathrm{~m} 2$ \\
\hline Oxidação química & $\$ / \mathrm{m} 3 /$ Ano & Ano & (R\$\$/Unid/Ano) & Unid \\
\hline EDSON, 2008 & $\mathrm{R} \$ 210.42$ & 2008 & $\mathrm{R} \$ 365.60$ & $\mathrm{~m} 2$ \\
\hline FRTR (Iin IPT, 2018) (1996, USEPA) & USD 242.81 & 2016 & $\mathrm{R} \$ 923.49$ & $\mathrm{~m} 2$ \\
\hline PICCHI, A.R., et al. (2009) (BR) & $\mathrm{R} \$ 183.33$ & 2016 & $R \$ 296.62$ & $\mathrm{~m} 2$ \\
\hline \multirow[t]{2}{*}{ MARCELINO $(2016, \mathrm{BR})$} & $R \$ 1,813.33$ & 2016 & $R \$ 2,070.46$ & $\mathrm{~m} 2$ \\
\hline & & Média & $\mathrm{R} \$ 914.04$ & $\mathrm{~m} 3$ \\
\hline Recuperação de fase livre & $\$ / \mathrm{m} 3 /$ Ano & Ano & (R\$\$/Unid/Ano) & Unid \\
\hline \multirow[t]{2}{*}{ FRTR (lin IPT, 2018) (1996, USEPA) } & USD 0.66 & 2016 & $\mathrm{R} \$ 2.49$ & $\mathrm{~m} 2$ \\
\hline & & Média & $\mathrm{R} \$ 2.49$ & $\mathrm{~m} 2$ \\
\hline
\end{tabular}

Obs. 1 - Valores foram convertidos para $\$$ / unid / ano.

Obs. 2 - Valor em outra moeda foi convertido para o Real no ano do trabalho publicado.

Obs. 3 - Todos os valores foram corrigidos para Dez / 2018, conforme INCC médio anual. 


\subsubsection{Compensação do dano ambiental irreversível}

Em relação às áreas contaminadas, a ocorrência destas, inicialmente, afeta a área do imóvel e, consequentemente, o valor do mesmo. Logo, o valor da propriedade é influenciado, segundo Mundy (1992), pela natureza das atividades desenvolvidas no terreno, bem como, do seu entorno. Esta influência foi denominada de "estigma", uma percepção da população que associa o terreno a algo ruim, de caráter subjetivo, e o local acaba sendo desvalorizado, proporcionando uma menor renda, potencial ou não. Seu estudo indicou, ainda, que o imóvel tende a não recuperar totalmente o valor inicial (sem a contaminação), mesmo após a remediação.

É possível que, com a nova abordagem das empresas de comunicação e adoção da "transparência" das informações, associada ao maior conhecimento da população sobre o tema adquirida (e a ser adquirido) ao longo dos anos, o percentual do estigma apresente tendência de diminuir, aproximando-se do zero, decorrente da perda do "medo" das áreas contaminadas.

Diversos estudos internacionais são desenvolvidos com o objetivo de quantificar o impacto da área contaminada no valor de um imóvel. Maynard et al. (2014) dividiu os estudos existentes na literatura internacional em: a) os que estudam o valor da área contaminada e, b) os que estudam o efeito da contaminação e outros fatores externos no valor do imóvel.

Segundo NSW (2017), quando se efetua a valoração de um terreno contaminado, devese, primeiro, definir se a contaminação deve ser remediada ou não e, em caso positivo, quais os custos envolvidos. Em relação ao dano ambiental decorrente da contaminação, define que:

a) Deve ser associado o valor de uso mais nobre do imóvel (permitido no zoneamento urbano local), considerando-se os custos de imóveis similares na região sem a contaminação, uma vez que a contaminação não pode ser fator limitante para o uso do terreno.

b) A diferença do valor do imóvel para o uso mais nobre permitido (sem a contaminação) e o valor atual (com a contaminação) é o valor do dano ambiental atribuído à contaminação. 
c) Se as construções existentes, devido à contaminação, não puderem ser utilizadas, estas não devem ser consideradas melhorias e, valoradas e somadas ao valor do dano do imóvel.

d) Para o valor final do imóvel, devem-se, ainda, ser descontados os custos da investigação e remediação da área. Caso não haja estudos específicos que estabeleçam o valor real da remediação da área, devem ser considerados custos médios de remediação.

Antai (2003), em seu estudo comparativo de metodologia e avaliação de imóveis contaminados na Suécia e na Nova Zelândia, verificou a semelhança de metodologias entre os países. Em ambos os países, é comum a valoração do imóvel (em seu máximo potencial em função do zoneamento urbano) sem a contaminação, sendo descontado, apenas, o valor dano ambiental sobre o valor inicial para se chegar ao valor do imóvel contaminado.

Herbert (2011), em seu trabalho de valoração de imóveis industriais contaminados (contaminação de solo por metais), indica uma deficiência da literatura brasileira sobre o tema, em especial dos conceitos teóricos e das técnicas de valoração econômica ambiental. Indica, ainda, que estudos dessa natureza, para uma correta quantificação do valor do imóvel influenciado pela existência da área contaminada sobre o mesmo, devem considerar os custos da recuperação da contaminação e suas despesas operacionais, entre outros fatores.

O estudo de caso efetuado por Herbert (2011) aplicou o método comparativo direto para a valoração do imóvel, conforme diretrizes descritas na NBR 14653 - Parte 2 da ABNT, bem como o método proposto por Mundy (1992) de valoração da propriedade e obteve valores finais semelhantes. Entretanto, quando aplicou o método Mundy de valoração da propriedade com a presença da contaminação, obteve uma desvalorização de $39 \%$ do valor do imóvel. Quando da valoração do imóvel após a remediação da área, verificouse uma diferença no valor de mercado da propriedade, menor que a anterior, confirmando a ocorrência do "estigma" que afeta o valor final, conforme proposto por Mundy (1992).

Em estudo de desvalorização de imóvel decorrente da ocorrência da contaminação, efetuada pelo IPT (2018), considerando o estudo de caso de 5 casos em São Paulo, foi obtido um estigma médio de $31 \%$. 
Shideler e Dicks (2011) desenvolveram um estudo comparativo entre 16 (dezesseis) comunidades de forma a avaliar o impacto econômico do estigma resultante de uma antiga contaminação ambiental de uma fundição de zinco em um município no Oklahoma. O estudo conclui que o estigma pode afetar até mesmo o Estado, através das perdas (taxas e impostos) econômicas do município. Assim, concluíram que este aspecto econômico do dano ambiental decorrente de áreas contaminadas deve ser melhor avaliada.

Barbisan et al. (2007) efetuaram um estudo de valoração de área degradada em zona urbana, utilizando a técnica de disposição a pagar, avaliada através de entrevistas com moradores em uma área do Município de Passo Fundo / RS, sem, contudo, avaliar a ocorrência de área contaminada. Os autores concluíram que existe, por parte da sociedade em geral, uma percepção da importância da qualidade do meio ambiente urbano, com clara preocupação quanto às questões ambientais e as graves consequências que a degradação ambiental ocasiona.

A CETESB desenvolveu no início da década 90 (MARCELINO et. al., 1992), em atendimento a uma solicitação do Ministério Público Federal, critérios básicos para a valoração de danos causados por vazamentos de petróleo e seus derivados no ambiente marinho a saber: a) volume de óleo derramado; b) vulnerabilidade da área atingida; c) toxidade e persistência do produto no meio, e; d) mortalidade de organismos. Os critérios eram classificados por sua importância relativa em graus variando de 0,0 a 0,5. A metodologia desenvolvida, baseada na experiência prática dos autores, considerou os principais aspectos visíveis do acidente ambiental, de forma a ter fácil e rápida aplicação. Resultou em uma equação exponencial representativa dos acidentes, que tanto ocorriam na época, dada pela Equação 4.2.

$$
\text { Valor do Dano (US\$) }=\mathrm{K} * 10^{(4,5+X)} \text { [Equação 4.2] }
$$

Onde:

$K=\underline{\text { Fator de reincidência, }}$ que associa uma "negligência" ao responsável e uma consequente penalidade ao mesmo, aumentando o valor em função do número de ocorrências de danos ao longo do tempo. A primeira ocorrência tem fator 1 , a segunda $=2$, a terceira $=4$, a quarta $=8$ e as subsequentes, 32 .

$$
X=\left(S_{1}+S_{2}+S_{3}+S_{4}+S_{5}+S_{6}\right) \text {, sendo: }
$$


$\mathrm{S}_{1}$ - Fator do óleo sobre o meio, dado pelo volume do produto, considerando-se uma avaliação subjetiva da assimilação do produto pelo ambiente, que varia em função da estação do ano e condições meteorológicas. Volumes inferiores a $1,0 \mathrm{~m}^{3}$ tem fator $0,1 \mathrm{e}$, superiores a $150 \mathrm{~m}^{3}$, fator 0,5 .

$\mathrm{S}_{2}$ - Vulnerabilidade da área impactada, avaliada através da interação da costa terrestre com os processos (físicos) que controlam a deposição e a persistência do óleo. Assim, o manguezal tem fator maior que um costão rochosos, por exemplo.

$\mathrm{S}_{3}-\underline{\text { Toxicidade do Produto }}$ sobre os seres vivos, obtida diretamente na Ficha de Informação de Segurança de Produto Químico - FISPQ.

$\mathrm{S}_{4}$ - Efeito deletério do produto, o quanto e nocivo, baseado em estudos anteriores.

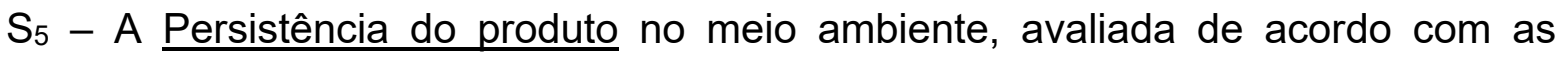
propriedades físicas do mesmo. Em geral, quanto maior seu peso específico, maior será sua persistência.

$\mathrm{S}_{6}$ - A Mortalidade de organismos decorrente do derrame, tanto pela sua toxidade quanto por processos físicos (asfixia, imobilização, etc.).

Bertolo et al. (2019), estabeleceu uma metodologia de cálculo do valor econômico para a indenização dos serviços ecossistêmicos prestados pelas águas subterrâneas afetados pela presença residual dos contaminantes nos aquíferos, após a remediação e reabilitação da área, de forma a indenizar a sociedade e colaborar com o financiamento da gestão dos recursos hídricos. 
Dentre as equações gerais propostas para dimensionar o valor da água subterrânea em suas diferentes funções e serviços, destaca-se a indicada para os Serviços de Provisão, para o fornecimento de água potável ou não potável, mediante extração, para consumo humano e diversos fins (uso direto). A metodologia proposta baseia-se no cálculo do volume de água impactada pelos contaminantes pelo valor da água na região, tendo por base a expressão matemática de Valor Econômico de Recurso Ambiental - VERA (ABNT NBR 14653-6, 2008), que expressa a disposição a pagar ou a receber para compensação pelo dano, conforme definido pela Equação 4.3.

$$
V A=V_{\text {cont }} * \mathrm{R} \$ \text { [Equação 4.3] }
$$

$\mathrm{VA}=$ Valor da Água (em $\mathrm{R} \$)$.

$\mathrm{V}_{\text {cont }}=$ Volume de água contaminada em um aquífero $\left(\mathrm{em}^{3}\right)$.

$\mathrm{R} \$$ = Custo de substituição da água $\left(\mathrm{em} \mathrm{R} \$ / \mathrm{m}^{3}\right)$.

Para a aplicação da proposta é necessário o cálculo do volume de água impactada e da extensão do impacto ambiental decorrente dos contaminantes, somente possível após o conhecimento detalhado do sistema aquífero, usualmente obtido nos trabalhos a partir da Investigação Detalhada (ID). Já o custo da água, o autor propõe considerar o valor de fornecimento pela concessionária pública, em substituição da impactada, ou o equivalente ao custo de extração de água subterrânea por poços na região, além de observar que o mesmo pode ser obtido de empresas de fornecimento por caminhão pipa.

De forma a adaptar-se as características de cada situação do serviço ambiental afetado a ser indenizado, Bertolo et al. (2019), propôs variações da Equação 4.3, conforme o serviço ambiental a ser atendido:

a) Aplicação do valor de custo de água potável para considerar o serviço ambiental de provisão, decorrente do uso direto da agua, isto é, quando o recurso hídrico subterrâneo é explotado para consumo, com ou sem tratamento prévio.

b) Aplicação do valor de custo de água bruta não potável para considerar o serviço ambiental de regulação, decorrente da manutenção dos sistemas aquíferos (recarga), quando o recurso hídrico subterrâneo não é explotado para consumo, com ou sem tratamento prévio.

São propostas, ainda, pelo autor, outras variações, que consideram: 
c) Serviço de regulação dos corpos d'água superficiais, através do impacto de qualidade ocasionado pelo fluxo de base dos mesmos por água subterrânea degradada. Assim, o volume a ser considerado é o produto da vazão de descarga no corpos de água superficial pelo tempo em que o aquífero permanece contaminado.

d) Serviço de suporte decorrente do próprio sistema aquífero, que proporciona a atenuação natural dos contaminantes e assim, o volume de água a ser considerado é decorrente do fluxo de água que passa pela seção contaminada ao longo do tempo de degradação até o reestabelecimento do padrão de qualidade original.

e) Serviço cultural, onde uma atividade deixar de operar decorrente da contaminação e, assim, o valor da água (VA) a ser considerado é decorrente da perda do faturamento do serviço pelo tempo que ocorrer a suspensão da atividade devido ao impacto ambiental. 


\section{ANÁLISE DE DADOS DO GERENCIAMENTO DE ÁREAS CONTAMINADAS NA VALORAÇÃO DO DANO AMBIENTAL}

\subsection{MODELO CONCEITUAL DO PROBLEMA}

Segundo a DD38 da CETESB (CETESB, 2017), com o desenvolvimento da Avaliação Preliminar (AvP) de uma área, são caracterizados, entre outros aspectos: a) o contexto fisiográfico da área; b) histórico de uso da área, com a discriminação do layout das atividades, matérias primas, produtos e resíduos manipulados no local com potencial de contaminar o terreno; c) existência de poço de abastecimento e bens a proteger; d) caracterização e localização de fontes potenciais de contaminação; e) substâncias químicas de interesse (SQI), e f) Modelo Conceitual inicial da área (MCA 1) com respectiva avaliação de confiança da informação.

Com a identificação de indícios ou suspeitas de contaminação da área (Art. 23 do Decreto 59.263/2013) na AvP ou fruto de uma demanda da CETESB, é efetuada a Investigação Confirmatória (IC) da local, de forma a verificar se a mesma está contaminada ou não, conforme descrito no capítulo 5.3.1. A confirmação da ocorrência de contaminantes em concentrações acima dos Valores de Intervenção estabelecidos pela CETESB classifica o local como Área Contaminada sob Investigação (ACI) e o responsável legal deve proceder às etapas de Gerenciamento de Áreas Contaminadas (GAC) subsequentes. Caso negativo, o processo de investigação é encerrado.

Cabe aqui, a observação de uma inconsistência da legislação do Estado de São Paulo, que gera dúvidas aos responsáveis legais e desvalorização precoce do imóvel. Ao final das atividades posteriores previstas no GAC, a área recebe uma classificação pelo Estado de Área Reabilitada para o uso declarado (AR), apesar de poder apresentar contaminantes em concentrações acima do Valor de Intervenção, desde que não apresenta riscos toxicológicos aos receptores perante o uso pretendido. Assim, porque, após a IC, a área recebe a classificação como Área Contaminada sob Investigação $(\mathrm{ACl})$ ? Afinal, neste momento (ao término da $\mathrm{IC}$ ), ainda não se sabe se a origem da anomalia ambiental e se a mesma apresenta risco aos receptores. O autor entende que o ideal seria que o termo Área Contaminada sob Investigação (ACI) fosse substituído por "Área com Anomalia Ambiental - AAA". 
Entretanto, após a IC, o impacto ambiental foi identificado (mesmo que não venha a oferecer risco toxicológico à saúde), assim como, a caracterização de onde a contaminação está inserida: imóvel (constituído do terreno / edificações / uso), bacia hidrográfica, vegetação, bens a proteger no entorno, etc..

Para a valoração do dano ambiental associado a áreas contaminadas, é proposta, nesta tese, as seguintes etapas:

1) Quantificar e valorar as ações de investigação da ocorrência da contaminação, seus riscos toxicológicos associados e níveis de reparação do dano reversível.

2) Caracterizar os valores associados ao(s) imóvel(eis) impactado(s): propriedade (nu-proprietário e usufrutuário), benfeitorias e potencial de ganho.

3) Quantificar e valorar as ações de planejamento e execução da remediação ambiental (reparação do dano reversível) e reconstituição do local.

4) Caracterizar e valorar os serviços ambientais impactados pela contaminação.

5) Caracterizar e valorar os danos reversíveis e a compensação dos danos irreversíveis.

Todo este procedimento deve ser valorado. A Figura 5.1apresenta a Estrutura Analítica de Valoração (EAV) do dano ambiental associado a áreas contaminadas.

\subsection{REPRESENTATIVIDADE DOS DADOS ANALISADOS}

O processo de gerenciamento de área contaminada é contínuo e varia em função do risco detectado, constantemente reavaliado, etapa a etapa, considerando-se as Concentrações Máximas Admissíveis (CMA) calculadas (com base no risco) para a área, conforme ilustra a Figura 5.2. 


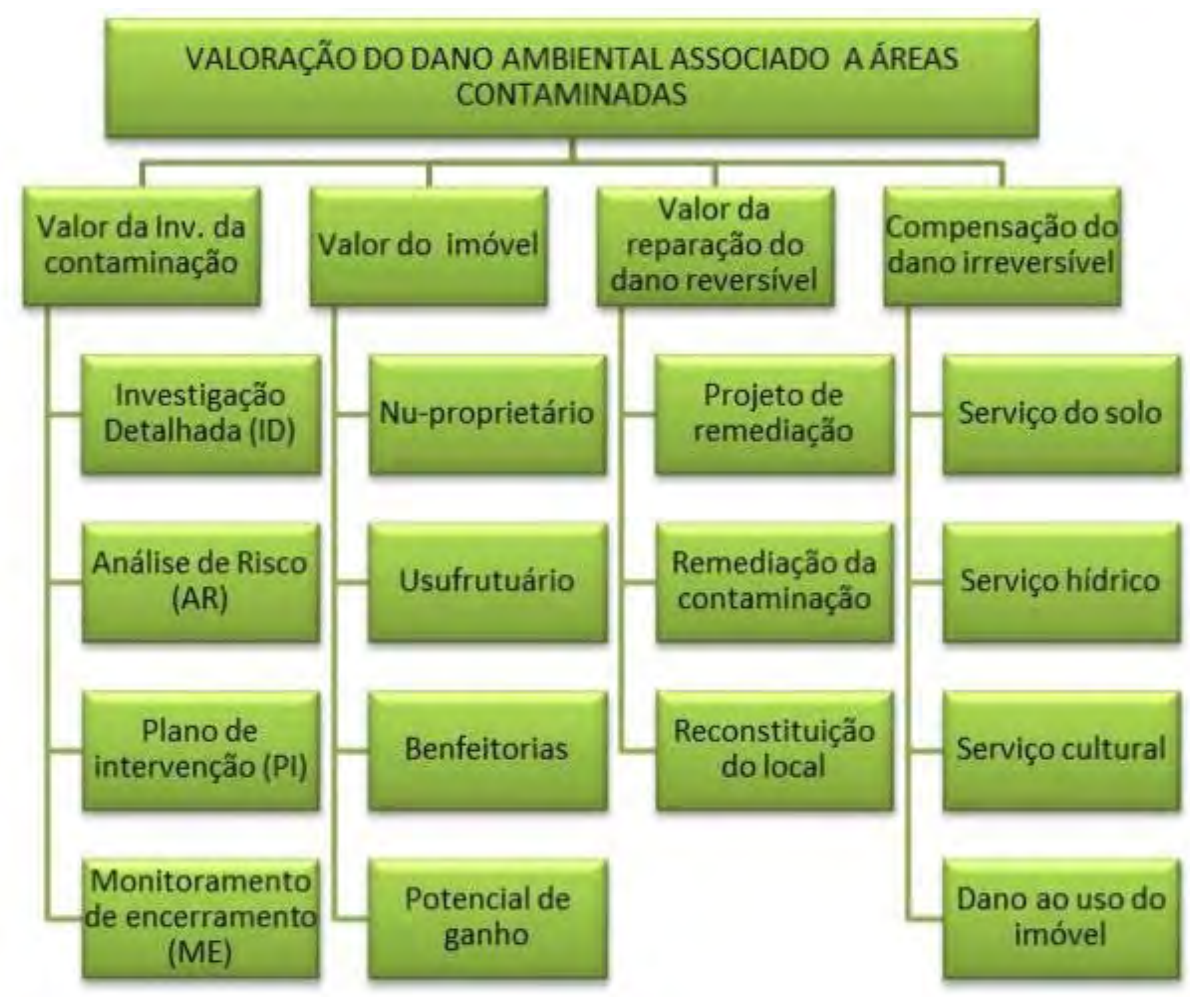

Figura 5.1 - Proposta da Estrutura Analítica de Valoração (EAV) do dano ambiental associado a áreas contaminadas.

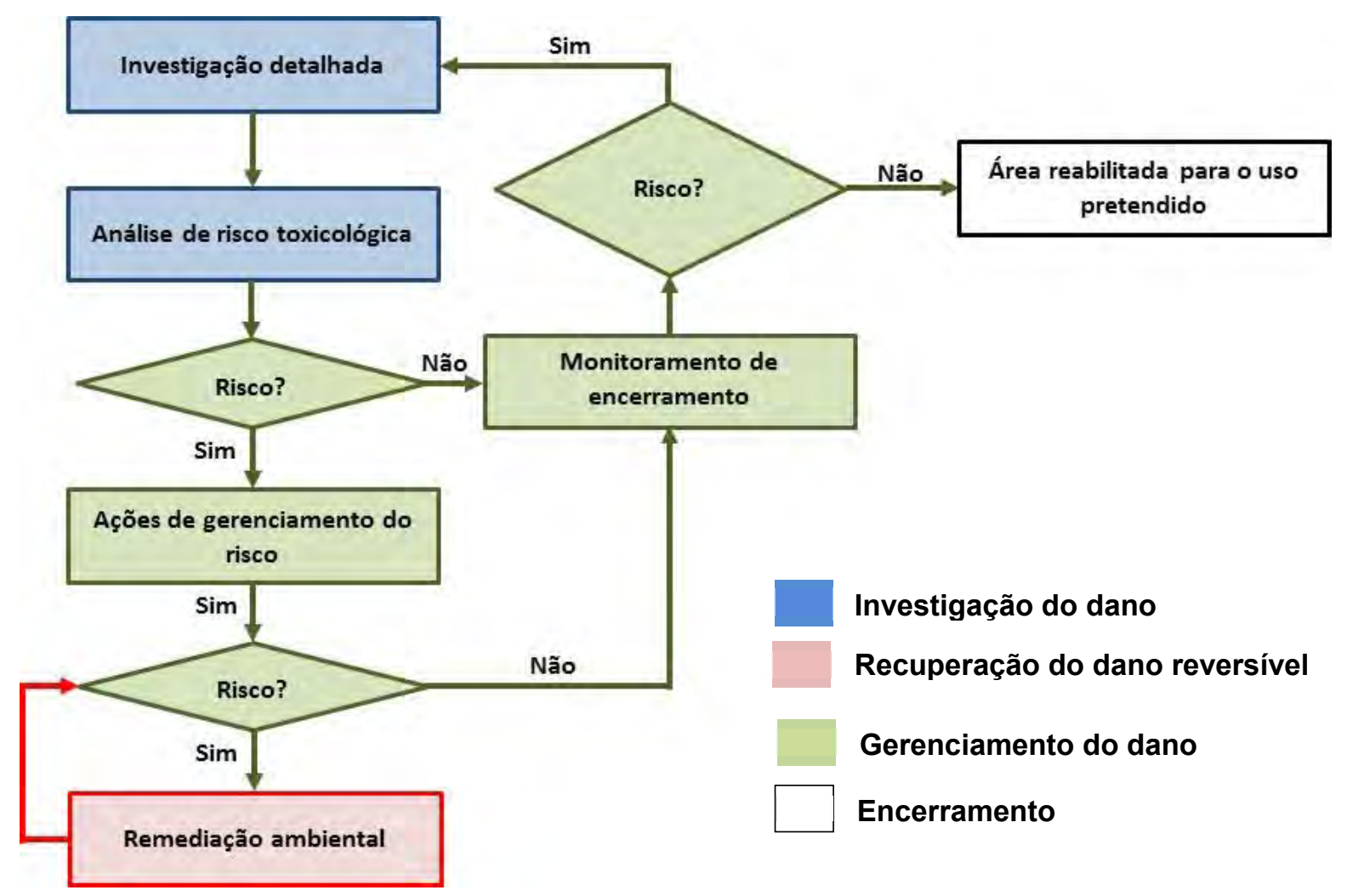

Figura 5.2 - Fluxograma das etapas de investigação do dano ambiental e reparação dos danos reversíveis. 
Para a quantificação das atividades necessárias para a investigação da ocorrência da contaminação e das ações de remediação do dano reversível, foram levantados e avaliados relatórios de gerenciamento de área contaminada por combustíveis fósseis, obtidos perante empresas de consultorias, de distribuição de combustíveis e retalhistas. Inicialmente, os documentos recebidos foram identificados e separados por sua localização, sendo utilizados apenas os trabalhos desenvolvidos no Estado de São Paulo. A escolha dos trabalhos desenvolvidos em São Paulo objetivou a uniformização dos procedimentos, uma vez que os trabalhos teriam a mesma fiscalização (CETESB) e legislação a atender.

Foram selecionados para uso, os documentos associados as áreas contaminadas que possuíam todo o processo completo de gerenciamento, os relatórios técnicos correspondentes a todas as etapas desenvolvidas do gerenciamento de área contaminada e obtiveram o encerramento das atividades e reabilitação da área, tendo ou não desenvolvido a etapa de remediação - reparação do dano reversível.

A seleção efetuada resultou em 725 (setecentos e vinte e cinco) documentos com 878 (oitocentos e setenta e oito) etapas de Gerenciamento de Áreas Contaminadas (GAC), representativas de 44 (quarenta e quatro) áreas distintas, emitidos entre Junho de 1980 e Fevereiro de 2018, que foram convertidos em números, conforme apresentado no Anexo II. A Figura 5.3 apresenta a localização destas áreas no contexto geológico do Estado de São Paulo, onde é possível observar que sua distribuição no Estado abrange os principais litotipos de São Paulo.

Os relatórios analisados foram emitidos por 21 (vinte e uma) empresas de consultorias diferentes, (sendo uma não identificada, com nome não constante no documento), contratadas por 10 (dez) bandeiras revendedoras de combustíveis, sendo que uma

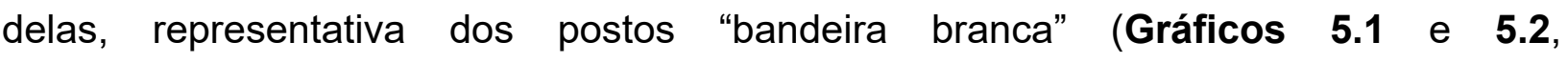
respectivamente).

Considerando que das 6.110 (seis mil, cento e dez) áreas contaminadas divulgada pela CETESB em 2018 (CETESB, 2018), 4.384 (quatro mil, trezentos e oitenta e quatro) são postos de serviços (população objeto desta pesquisa), representando $48 \%$ do total de postos localizados no Estado de São Paulo. As 44 (quarenta e quatro) áreas analisadas fornecem um nível de confiança de $90 \%$, com uma margem de erro de $12,37 \%$. 


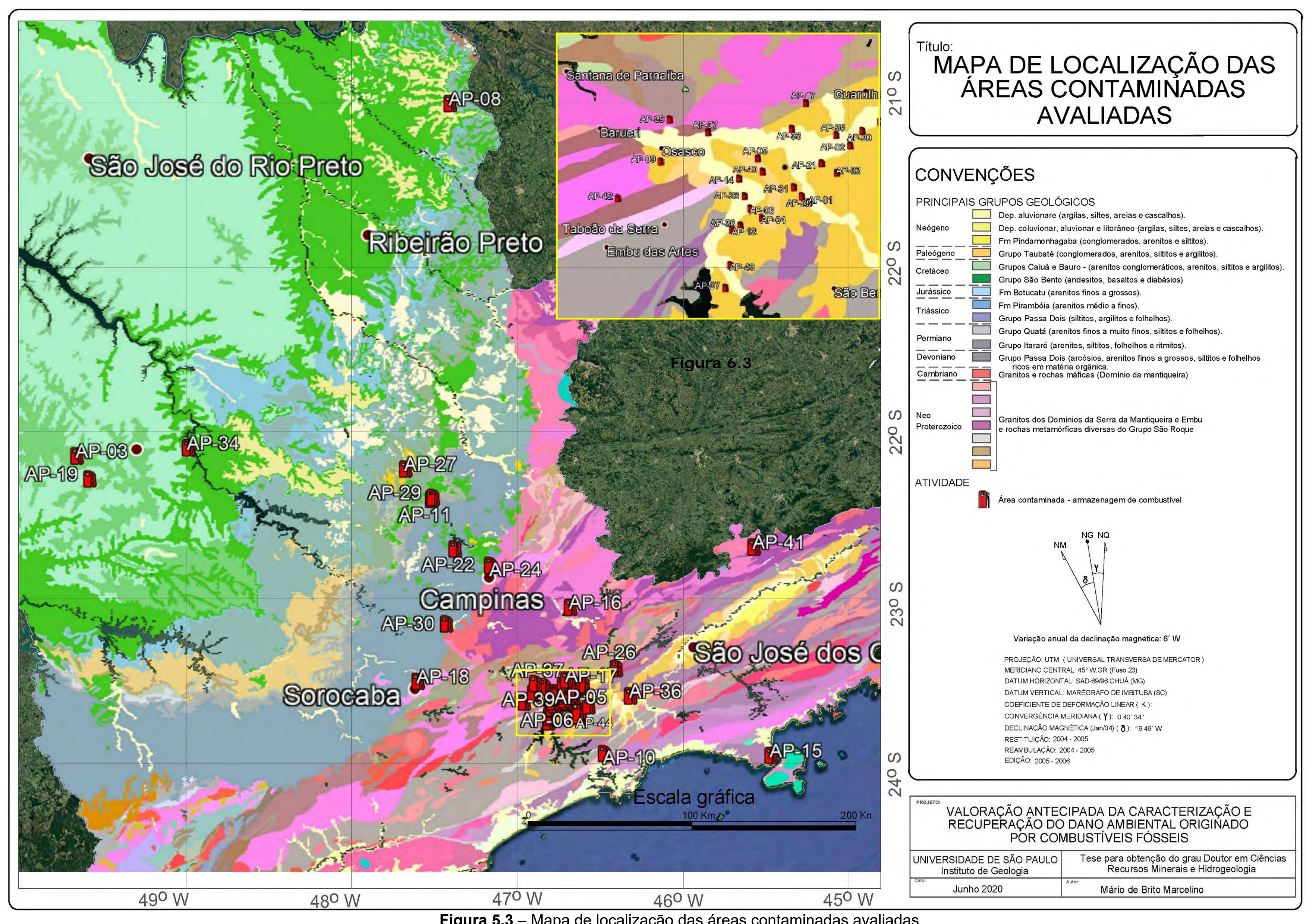

Figura 5.3 - Mapa de localização das áreas contaminadas avaliadas. 


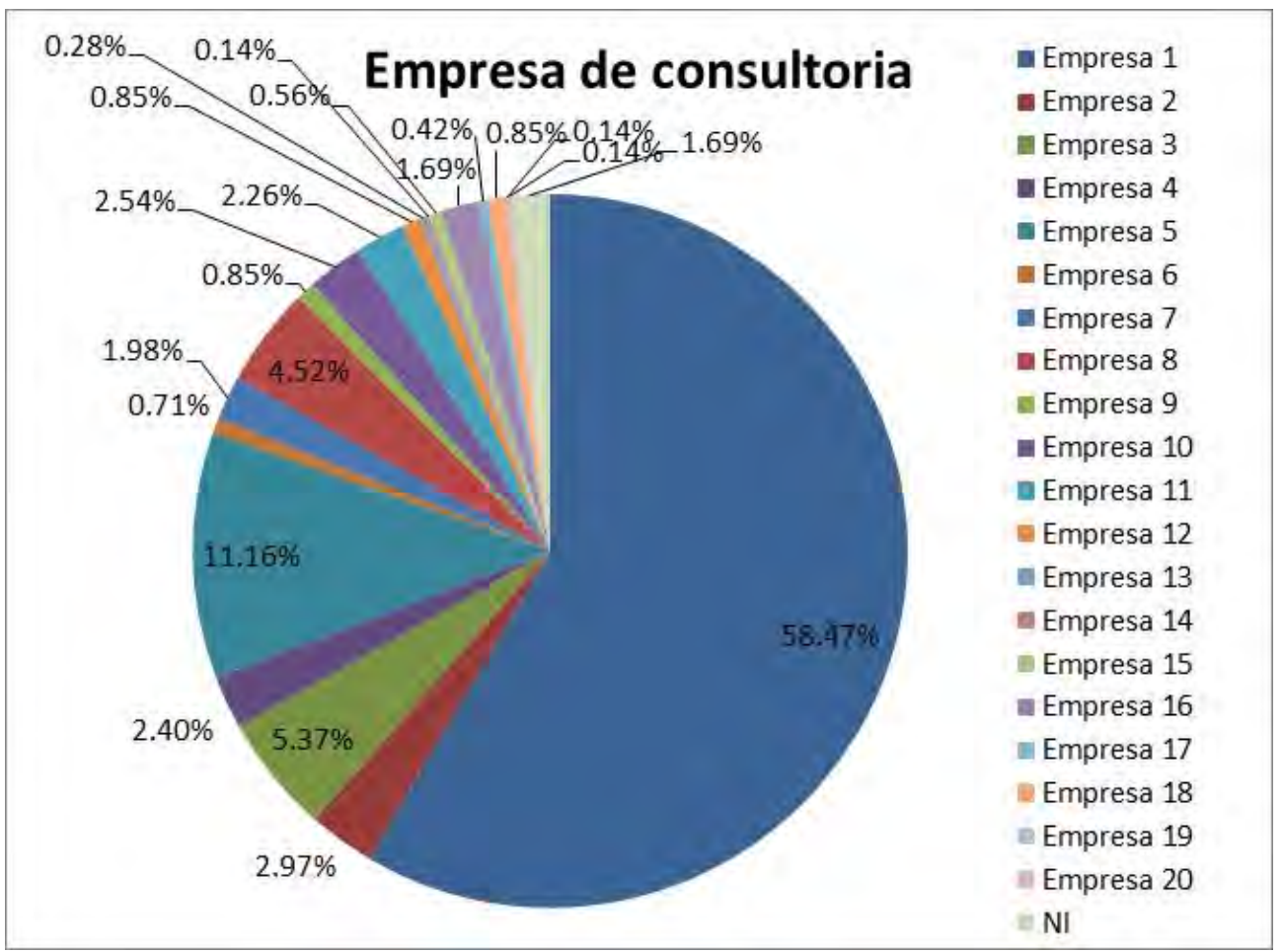

Gráfico 5.1 - Representatividade do percentual das empresas de consultoria que elaboraram os relatórios de gerenciamento ambiental ( $\mathrm{NI}=$ Não identificado).

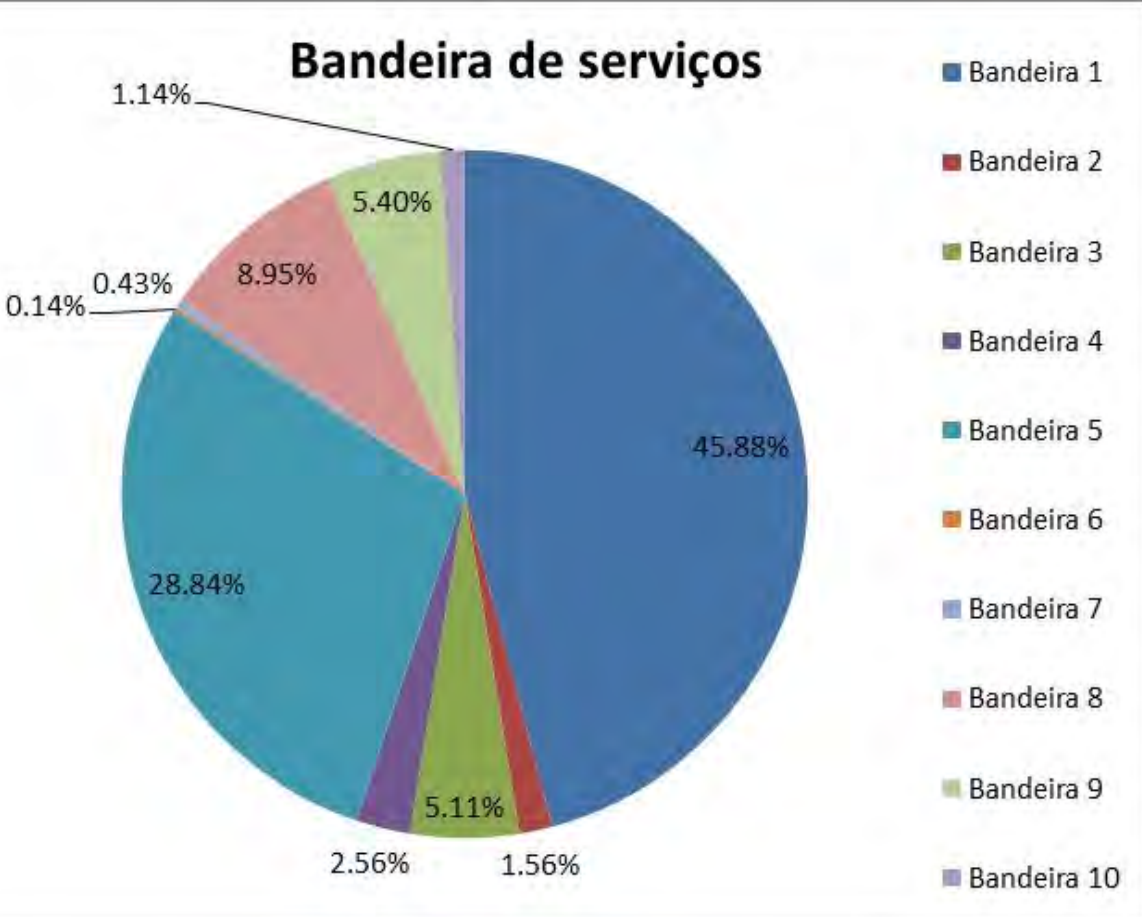

Gráfico 5.2 - Representatividade do percentual das Bandeiras revendedoras de combustíveis. 
Cabe destacar que, dos 44 (quarenta e quatro) casos analisados, 39 (trinta e nove), ou $88,64 \%$ dos casos, tiveram seus processos de GAC encerrados e 4 (quatro) dos casos $(9,09 \%)$, desenvolveram apenas a Investigação Confirmatória (IC), etapa anterior a Investigação Detalhada (ID), por não terem caracterizado anomalias ambientais na área, em relação aos padrões legais.

As informações existentes nos relatórios analisados (e informações verbais) foram verificadas na relação de áreas contaminadas publicadas pelo Estado de São Paulo em 2019 (CETESB, 2019), e constatou-se uma boa correlação entre as mesmas.

Entretanto, observam-se algumas diferenças, tais como:

a) A existência de casos analisados não constantes na relação publicada pela CETESB, sugerindo uma deficiência do cadastro ou não comunicação do responsável legal da área contaminada.

b) Uma defasagem entre a classificação atual (representativa da etapa GAC em desenvolvimento) constante na relação e a etapa já desenvolvida, apresentada nos relatórios técnicos recebidos.

A defasagem pode ser entendida como: i) consequência da demora da digitalização das informações pelo órgão de fiscalização; ii) do não encaminhamento de relatórios devido aos prazos pactuados ou; iii) decorrente da "antecipação" de etapas pelo cliente antes da manifestação oficial da CETESB.

c) Algumas das áreas existentes na relação da CETESB apresentam responsável legal diferente do registrado nos relatórios técnicos.

Entende-se que a diferença do responsável legal (nome do posto) observada é da alteração decorrente de processos de compra e venda.

d) Diferenças de registros de metodologia de remediação aplicadas na área ou mesmo a reabilitação sem que tenham ocorrido medidas de remediação (que os relatórios indicam ter ocorrido), seja por deficiência de cadastro da CETESB ou não encaminhamento de todos os relatórios efetuados para o órgão de fiscalização. 
e) Observa-se que algumas áreas tinham sido reabilitadas, mas, posteriormente, deve ter ocorrido vazamento de combustível e, assim, em 2018, consta como em remediação por Pump \& Treat (P\&T).

O volume de relatórios e documentos a serem avaliados, por mais que a equipe técnica da CETESB seja altamente qualificada, impossibilita uma rápida atualização das informações existentes no banco de dados.

Assim, registra-se aqui, a sugestão para a CETESB desenvolver e disponibilizar um programa de computador, de acesso público, que possibilite a digitação direta das informações e documentos associados da área contaminada em um grande banco de dados pelo próprio responsável técnico e legal, com responsabilidade associada através de certificados de assinatura digital reconhecido. $O$ procedimento irá desonerar os técnicos da CETESB na digitalização das informações, passando a ser de responsabilidade do responsável legal e/ou técnico.

Sugere-se, ainda, que as informações das áreas contaminadas cadastradas sejam mais facilmente acessadas, que possam ser obtidas no site da CETESB em formatos digitais usualmente utilizadas pelos técnicos e pesquisadores (planilhas, mapas vetorizados georreferenciados, etc.) de forma a fomentar o desenvolvimento pesquisas. Hoje, as informações são disponibilizadas para o público, mas em formato de difícil manipulação, utilização e gestão.

A análise inicial das informações indica uma data média ponderada de instalação dos postos de serviços no ano de 1981 e ano médio de instalação em 1977 (Gráfico 5.3). A distribuição da instalação dos postos apresenta boa correlação com o desenvolvimento econômico do Brasil, com o maior número de postos instalados quando do "milagre econômico" ocorrido entre 1969 e 1970, e a abertura econômica ocorrida a partir de 1990, períodos estes separado pela recessão e crise monetária ocorrida entre 1973 a 1990.

Considerando a data média de instalação dos postos em 1977, o período médio de 23 anos para ocorrer a primeira atividade de GAC (Gráfico 5.4), coincide com a publicação da resolução do CONAMA 273/2000, quando, por força de lei, os proprietários dos postos foram obrigados a efetuar a investigação ambiental para obter seu licenciamento. 


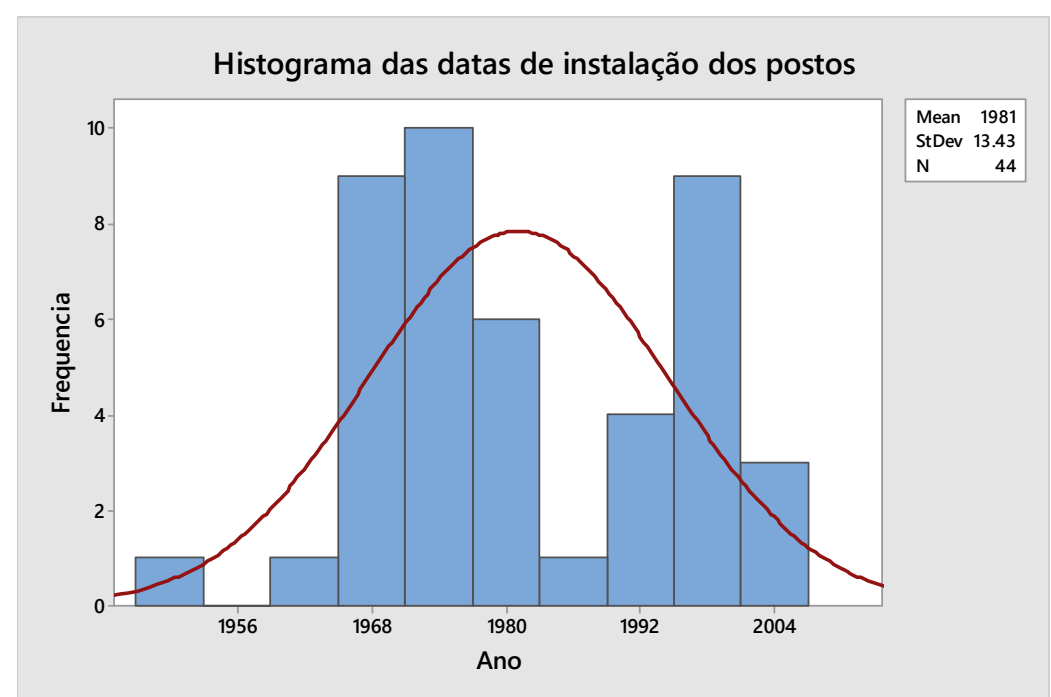

Gráfico 5.3 - Histograma da variação da data (ano) de instalação dos postos de serviços avaliados.

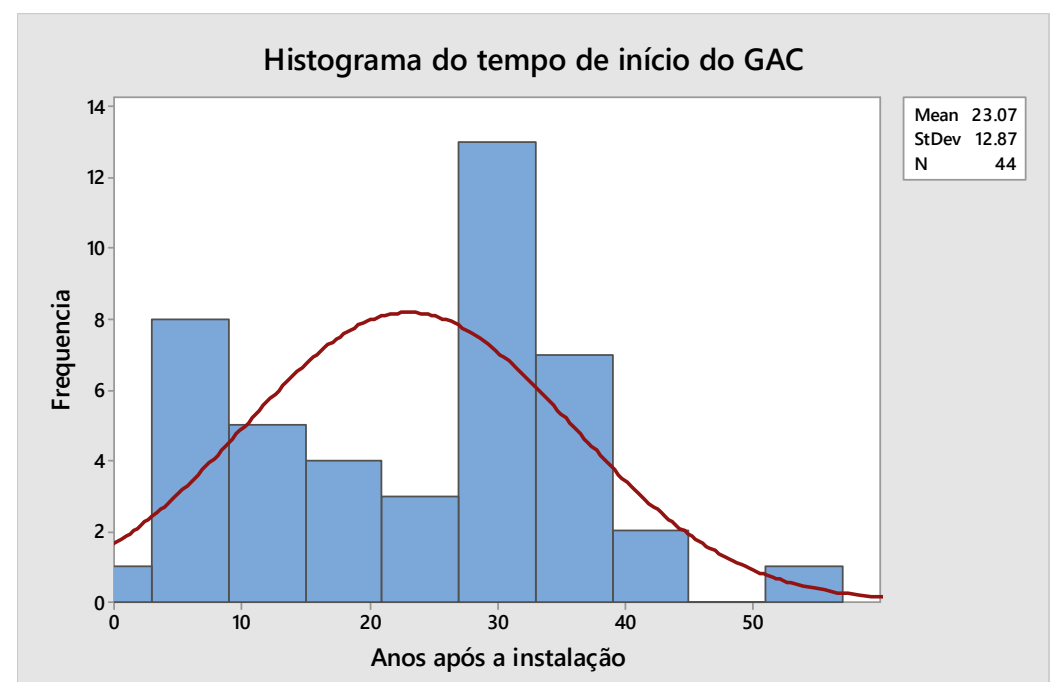

Gráfico 5.4 - Histograma do tempo (anos) para o início da primeira atividade de Gerenciamento de Área Contaminada (GAC) após a instalação do posto.
ANÁLISE ESTATÍSTICA

Data de instalação do posto de serviço

(Data)

Média $=1981$

Erro padrão $=\quad 2,0$ anos

Desvio padrão $=13,1$ anos

Mediana $=1977$

$\mathrm{N}^{\circ}$ amostras $=$

\section{ANÁLISE ESTATÍSTICA}

Prazo de início da atividade

GAC

(Ano)

Média $=$

23 anos

Erro padrão $=1,9$

Desvio padrão $=\quad 12,9$

Mediana $=28$ anos

$\mathrm{N}^{0}$ amostras $=$

Assim, além da obrigatoriedade da realização da investigação ambiental das áreas dos postos de gasolina, a vida útil dos equipamentos instalados nos postos (com mais de 23 anos, em média), contribuíram para o grande número de áreas contaminadas cadastradas no Estado de São Paulo.

Entretanto, cabe ressaltar que os trabalhos de Avaliação Preliminar (AvP) avaliados são deficientes quanto à caracterização do histórico do posto de serviços (muitos sequer caracterizam a data de instalação do postos investigados e, nenhum, a atividade anterior da área). 
Quando da avaliação dos relatórios, foi necessário, em muitos dos casos, efetuar, ao longo desta pesquisa de doutorado, o levantamento de uso e ocupação históricos do local e as datas de instalação dos postos investigados, por não constar nos relatório. O levantamento indicou, em alguns casos, que o local já possuía um posto de serviço anterior na área, não considerado nos relatórios.

A correta identificação do uso e ocupação históricos não foi possível de ser efetuada neste trabalho, e, assim, a data de instalação foi considerada a do primeiro posto do local.

Os registros avaliados são representativos das várias etapas do GAC e das diversas técnicas de remediação (REM) aplicadas para contaminantes decorrentes de combustíveis fósseis. As informações indicam 480 (quatrocentos e oitenta) registros, ou $54,79 \%$ do total, representativos da etapa de REM, devido ao longo período associado a esta etapa e a necessidade dos monitoramentos de eficácia e eficiência dos processos usualmente efetuados (Gráfico 5.5).

A etapa de Monitoramento de Encerramento (ME), com 151 (cento e cinquenta e um)

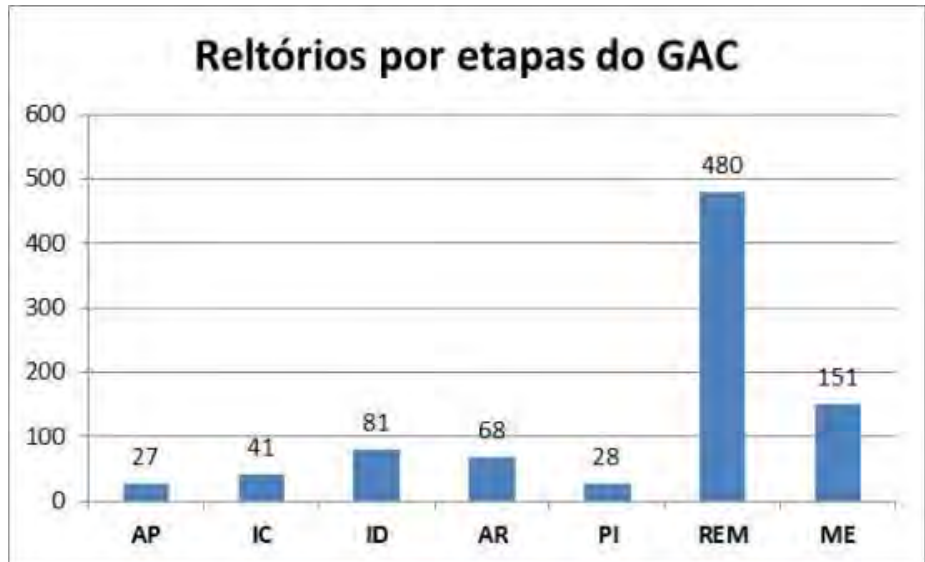
documentos, ou $17,24 \%$ do total de informes analisados, é a segunda etapa que mais gera documentos, devido à necessidade de ocorrerem mais de uma campanha de monitoramento para a caracterização da manutenção das condições ambientais (hoje, é uma

Gráfico 5.5 - Representatividade do número de documentos (relatórios) associados as etapas de Gerenciamento de Área Contaminada (GAC). obrigatoriedade legal ocorrerem, no mínimo, 4 - quatro campanhas de monitoramento ao longo de dois anos hidrológicos). 
Cabe destacar que, dos 44 (quarenta e quatro) casos analisados, apenas 37 (trinta e sete) apresentam a execução de algum ME e, em 8 (oito) destes, foram efetuadas mais de uma sequência de monitoramento, havendo a intercalação (retorno) com ações de remediação ou ID e Análise de Risco toxicológico (ARtx), devido a alteração das condições ambientais verificadas anteriormente.

O retorno à etapa anterior de GAC, é aqui, denominado de recorrência de atividade.

\subsection{CARACTERÍSTICAS DAS AÇÕES DE GERENCIAMENTO DE ÁREA CONTAMINADA - GAC}

Os dados avaliados evidenciam uma não sequência natural de etapas, chegando a ocorrer a remediação sem que tenha ocorrido a Investigação Detalhada (ID) em 9 (nove) áreas avaliadas, representando $20,45 \%$ do total. Nestes casos, foi efetuada a execução da remoção de fase livre de combustível ou a remoção do solo sem que tenha ocorrido a ID.

Evidenciam, ainda, uma clara deficiência de execução de etapas, na prática, evidenciado pela necessidade da repetição (recorrência) da ID e da Análise de Risco toxicológico (ARtx) em 31 (trinta e um) dos 44 (quarenta e quatro) casos analisados, representando um índice de $70,45 \%$ das vezes que o combustível foi detectado acima dos valores de intervenção quando da Investigação Confirmatória (IC). Observam-se casos em que ID / ARtx foi executada até 7 (sete) vezes (destacado em vermelho) em uma mesma área e a remediação, troca ou alteração de metodologia de remediação, até 6 vezes em uma mesma área, conforme apresentado na Tabela 5.1.

Do total de áreas contaminadas levantadas, 39 (trinta e nove) desenvolveram etapas posteriores à IC, representando $86,36 \%$ dos casos avaliados, sendo que, uma das áreas, não foi desenvolvida quaisquer uma das etapas subsequentes à ID / ARtx.

Cabe destacar que, das 44 (quarenta e quatro) áreas analisadas, apenas 13 (treze) indicaram a ocorrência de vazamento ou perdas de combustível, sugerindo uma deficiência nas informações de origem da contaminação. 
Tabela 5.1 - Prazos caracterizados para o Gerenciamento de Área Contaminada (em meses), a partir do relatório da etapa anterior.

\begin{tabular}{|c|c|c|c|c|c|c|c|c|c|}
\hline \multirow{3}{*}{ 产 } & \multirow{3}{*}{$\begin{array}{l}\text { ID/Artx } \\
\text { Início }\end{array}$} & \multicolumn{5}{|c|}{ TEMPO } & \multicolumn{3}{|c|}{ N. vezes efetuado } \\
\hline & & \multicolumn{2}{|c|}{ Remediação } & \multicolumn{2}{|c|}{ ME } & \multirow{2}{*}{$\begin{array}{l}\text { Total } \\
\text { GAC }\end{array}$} & \multirow{2}{*}{$\begin{array}{c}\text { ID/ } \\
\text { ARtx }\end{array}$} & \multirow{2}{*}{ REM } & \multirow{2}{*}{ ME } \\
\hline & & Início & Total & Início & Total & & & & \\
\hline 1 & & & & & & & 0 & 0 & 0 \\
\hline 2 & & & & & & & 0 & 0 & 0 \\
\hline 3 & & & & & & & 0 & 0 & 0 \\
\hline 4 & 2 & 6 & 1 & 10 & 28 & 44 & 2 & 1 & 1 \\
\hline 5 & 10 & 2 & 17 & 9 & 38 & 73 & 3 & 2 & 3 \\
\hline 6 & 16 & 3 & 127 & 6 & 20 & 169 & 3 & 3 & 2 \\
\hline 7 & 34 & 3 & 132 & 0 & 17 & 184 & 5 & 6 & 1 \\
\hline 8 & 0 & 10 & 38 & 0 & 10 & 56 & 2 & 3 & 2 \\
\hline 9 & 0 & 15 & 11 & 6 & 13 & 42 & 1 & 1 & 1 \\
\hline 10 & 10 & 67 & 2 & 1 & 27 & 104 & 2 & 2 & 2 \\
\hline 11 & 7 & 1 & 56 & 5 & 52 & 119 & 2 & 3 & 3 \\
\hline 12 & 0 & 36 & 30 & 4 & 6 & 74 & 4 & 1 & 1 \\
\hline 13 & 25 & 68 & 62 & 0 & 10 & 164 & 7 & 3 & 3 \\
\hline 14 & 13 & 26 & 65 & 2 & 59 & 162 & 2 & 4 & 1 \\
\hline 15 & 8 & 5 & 29 & 7 & 19 & 65 & 1 & 1 & 1 \\
\hline 16 & 3 & 0 & 42 & 0 & 1 & 44 & 1 & 1 & 1 \\
\hline 17 & & 0 & 1 & 0 & 1 & 1 & 0 & 1 & 1 \\
\hline 18 & 17 & 12 & 37 & 1 & 1 & 49 & 2 & 2 & 1 \\
\hline 19 & & & & & & & 0 & 0 & 0 \\
\hline 20 & 74 & & & 7 & 19 & 98 & 2 & 0 & 1 \\
\hline 21 & 86 & & & 28 & 27 & 140 & 2 & 2 & 1 \\
\hline 22 & 2 & 0 & 1 & 14 & 29 & 42 & 1 & 1 & 1 \\
\hline 23 & 35 & 10 & 1 & 8 & 29 & 80 & 2 & 1 & 1 \\
\hline 24 & 51 & 0 & 1 & 51 & 41 & 91 & 1 & 1 & 1 \\
\hline 25 & 4 & 33 & 95 & 5 & 20 & 154 & 4 & 3 & 1 \\
\hline 26 & 3 & & & 2 & 1 & 4 & 2 & 0 & 1 \\
\hline 27 & 14 & 11 & 6 & 0 & 37 & 67 & 1 & 2 & 1 \\
\hline 28 & 0 & 69 & 12 & 2 & 1 & 82 & 2 & 1 & 2 \\
\hline 29 & 14 & 15 & 50 & 3 & 3 & 82 & 4 & 3 & 1 \\
\hline 30 & 39 & 0 & 1 & 37 & 1 & 39 & 1 & 1 & 1 \\
\hline 31 & 2 & 4 & 7 & 4 & 1 & 15 & 2 & 1 & 1 \\
\hline 32 & 44 & 6 & 43 & 0 & 2 & 92 & 3 & 4 & 2 \\
\hline 33 & 8 & 2 & 25 & 0 & 2 & 36 & 4 & 4 & 1 \\
\hline 34 & 0 & 0 & 1 & 0 & 0 & 1 & 1 & 1 & 0 \\
\hline 35 & 19 & -15 & 44 & 0 & 0 & 48 & 1 & 2 & 0 \\
\hline 36 & 0 & 4 & 48 & 9 & 1 & 59 & 3 & 2 & 1 \\
\hline 37 & 6 & & & 18 & 17 & 50 & 2 & 0 & 1 \\
\hline 38 & 1 & 22 & 11 & 3 & 1 & 74 & 1 & 2 & 1 \\
\hline 39 & 1 & 1 & 70 & 1 & 1 & 71 & 3 & 6 & 1 \\
\hline 40 & 1 & 31 & 53 & 3 & 1 & 86 & 1 & 2 & 1 \\
\hline 41 & 7 & 8 & 42 & 2 & 22 & 78 & 1 & 2 & 1 \\
\hline 42 & 13 & 4 & 23 & 4 & 30 & 70 & 1 & 2 & 1 \\
\hline 43 & 2 & 0 & 36 & 0 & 0 & 37 & 1 & 1 & 0 \\
\hline 44 & 63 & -62 & 152 & 3 & 12 & 166 & 2 & 6 & 0 \\
\hline
\end{tabular}

ID - Investigação Detalhada; ARtx - Análise de Risco toxicológico; REM - Remediação ambiental de solo ou água subterrânea; ME - Monitoramento de encerramento; -15= Símbolo negativo indica que a atividade iniciou antes da anterior. 
A análise dos dados ao longo da pesquisa evidenciaram que, em média, a ID / ARtx é executada após 16 (dezesseis) meses da confirmação da contaminação pela IC (Gráfica 5.6), e que, em 36 (trinta e seis) dos 39 (trinta e nove) casos avaliados, foram necessárias ações de Remediação (REM), representando um percentual de 92,31 \% das vezes. Este índice sugere que, uma vez identificado o contaminante antrópico em concentrações acima dos valores de intervenção da CETESB, dificilmente não ocorrerá alguma ação de diminuição de massa ou controle do dano reversível.

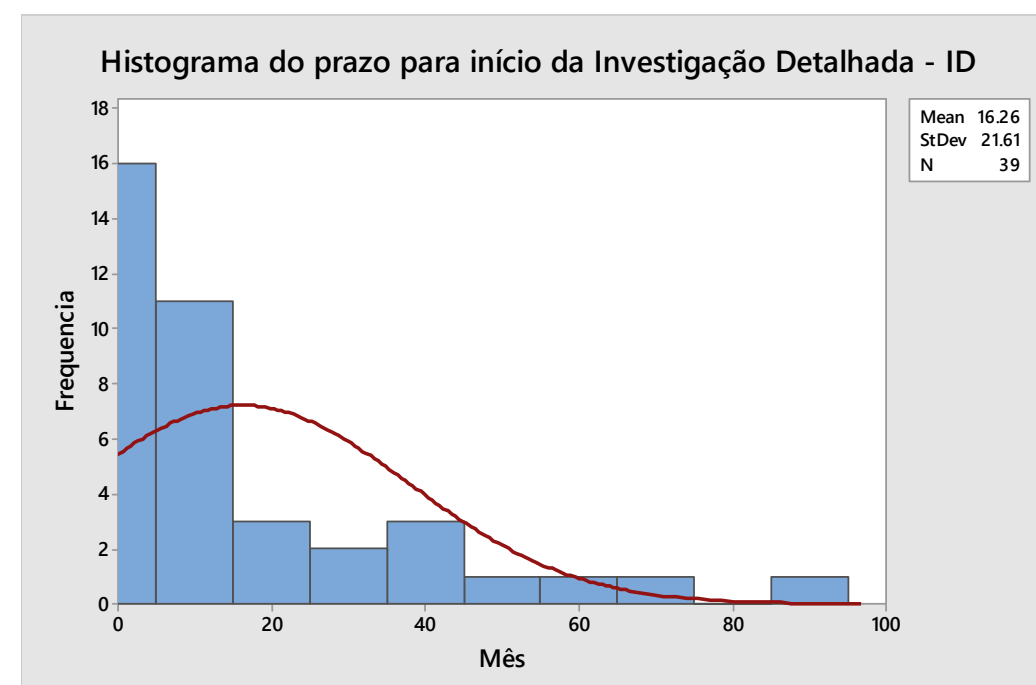

Gráfico 5.6 - Histograma de análise do tempo para início da realização da Investigação Detalhada (ID) após a Investigação Confirmatória (IC).

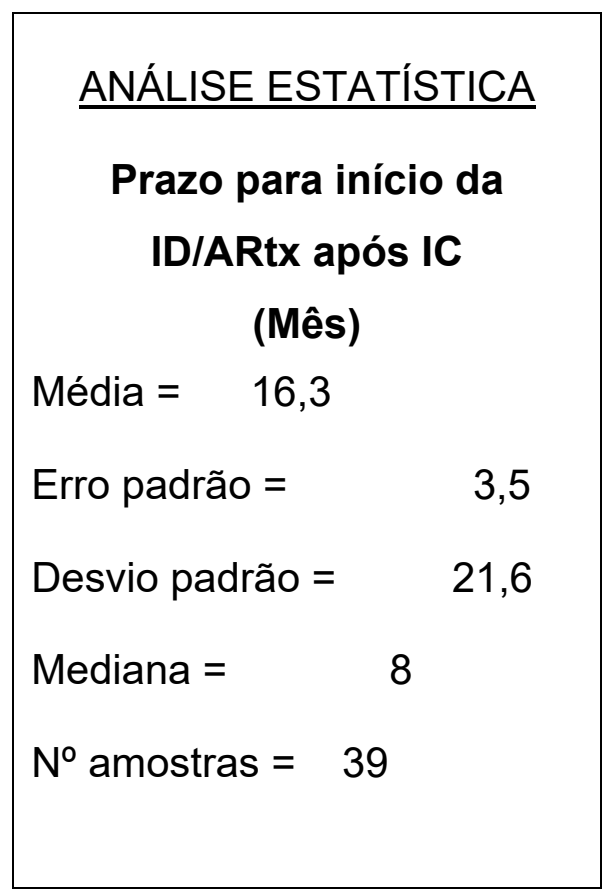

O Gerenciamento das Áreas Contaminadas (GAC) por combustíveis fósseis, analisado nesta tese, considerou a partir do recebimento do relatório de Investigação Confirmatória (IC), quando há a confirmação da anomalia ambiental e a obrigação legal de sua execução.

Considerando todos os dados (efetuando ou não ações de remediação), conclui-se que o GAC apresenta um prazo médio de 78 (setenta e oito) meses para seu encerramento perante o órgão de fiscalização, ou 6,5 (seis vírgula cinco) anos, com desvio padrão de 47 (quarenta e sete) meses, variando de 4 (quatro) a 190 (cento e noventa) meses (0,3 a 15,8 anos respectivamente), conforme ilustra o Gráfico 5.7.

Para a análise dos prazos, foram consideradas, para a pesquisa realizada, as datas de emissão dos respectivos relatórios de cada etapa de gerenciamento, não sendo avaliado o tempo de execução das atividades ou etapa correspondente ao relatório, conforme apresentado na Tabela 5.1. 


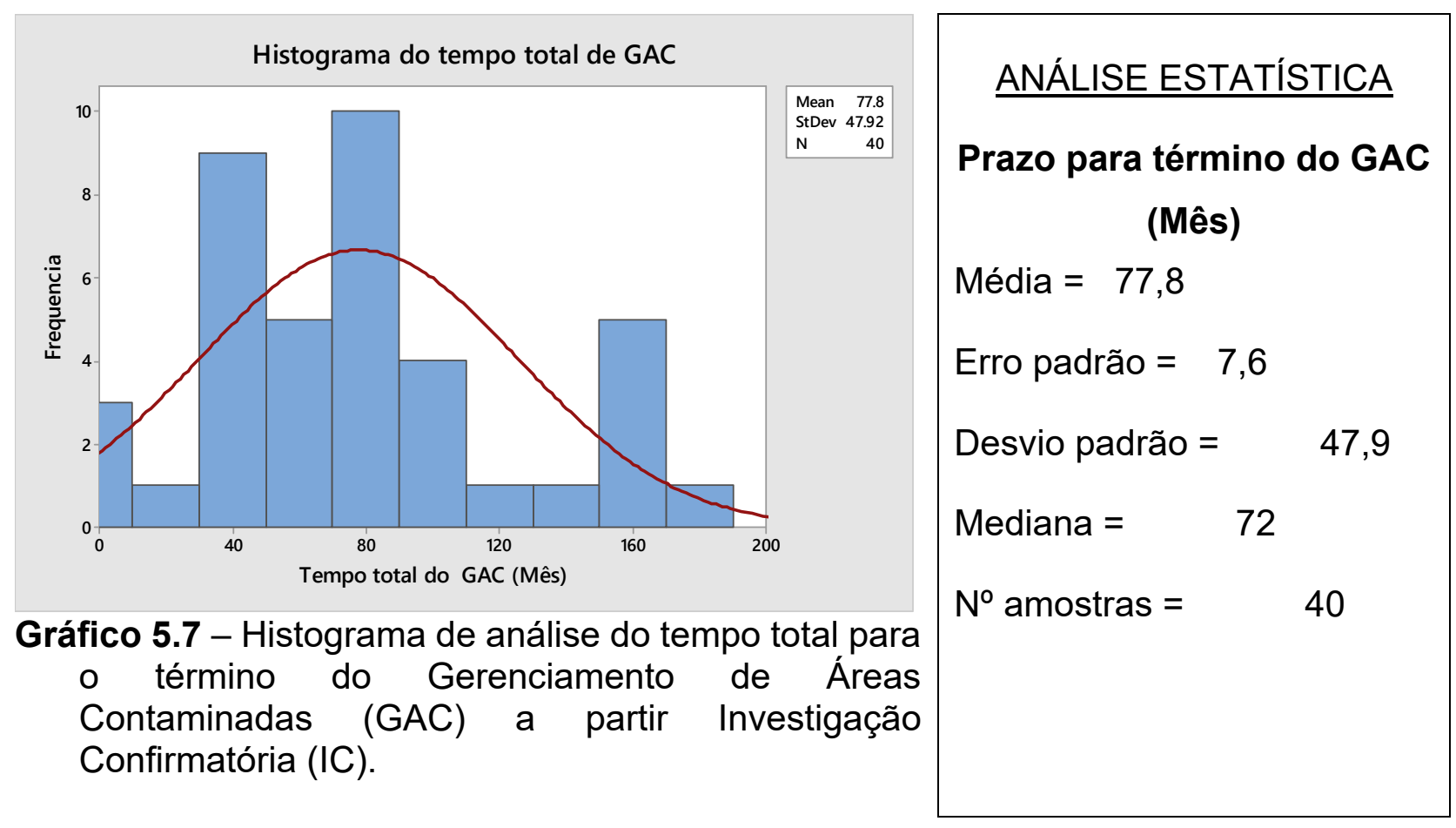

Os dados evidenciam uma grande variação em função da complexidade do tema, pois:

a) Apenas com as etapas de Investigação Detalhada (ID) e Análise de Risco toxicológico (ARtx) é que é possível estabelecer a necessidade ou não das ações de remediação do dano reversível, em função do risco associado. Quando não há a necessidade de ações de remediação, inicia-se o processo de Monitoramento de Encerramento (ME) e é possível obter a reabilitação da área em um prazo inferior a 3 (três) anos (considerando a necessidade de efetuar-se 2 - dois - anos de ME).

b) As ações de remediação do dano reversível são complexas e variam em função das características dos contaminantes e meio em que estão inseridos, entre outros aspectos técnicos. Cabem destacar fatores externos que influenciam no tempo total do gerenciamento da área contaminada, tais como: facilidades de instalação e operação do sistema de remediação, disponibilidade financeira e cultura do responsável legal pelo problema.

c) Até a Resolução CONAMA 273/2000 havia pouca exigência legal para o desenvolvimento das atividades de GAC em áreas de postos de combustíveis, muito menos uma preocupação com os prazos envolvidos. 
A preocupação com os passivos ambientais promoveu um progressivo aumento da legislação sobre o tema no Estado de São Paulo, com a CETESB apresentando (pela primeira vez) os procedimentos para o GAC com a DD 023/2000, juntamente com o Manual de Gerenciamento de Áreas Contaminadas, promovendo assim, uma melhor organização das atividades de GAC e atenção aos prazos envolvidos, agilizando, assim, todo o processo.

O prazo de 78 meses é quase o dobro da soma dos prazos totais de cada etapa indicados por MARCELINO (2018) e IPT (2018), para o desenvolvimento total do GAC. A diferença observada entre o prazo total e os indicados nos trabalhos citados na revisão bibliográfica pode ser explicada quando se avalia que a mesma é decorrente de:

- Uma avaliação subjetiva dos autores citados, conforme experiência pessoal.

- Os autores citados expressam condições ideais de execução de cada etapa do GAC e não informam os tempos entre o desenvolvimento de uma etapa e a subsequente, bem como, não consideram possíveis repetições de mesmas.

- Os autores consideram trabalhos desenvolvidos após a Resolução CONAMA $273 / 2000$, diferente dos trabalhos avaliados, que contemplam um período maior (anterior e posterior a 2000).

Assim, de forma geral, a análise dos dados do GAC indica que, na prática, o prazo total de execução é muito diferente do prazo indicado (na teoria) por MARCELINO (2018) e IPT (2018).

\subsection{QUANTITATIVOS DAS AÇÕES DE INVESTIGAÇÃO DO DANO REVERSÍVEL}

Para a análise quantitativa dos dados de investigação ambiental das áreas apreciadas nesta tese, todos os relatórios considerados foram inicialmente avaliados, parametrizados e inseridos em um banco de dados. 
Apesar de alguns dos documentos recebidos estarem incompletos (sem seus anexos), muitas das ausências das informações técnicas no texto do relatório avaliado não são justificáveis (relatórios de dimensionamento de sistema de remediação sem a informação da condutividade hidráulica do solo, porosidade, etc.) e sugerem, no mínimo, deficiência do documento, prejudicando qualquer análise técnica pelos órgãos de fiscalização.

Em conversas informais com alguns consultores, foi observado um consenso de possível má fé em relação à ausência de algumas informações técnicas nos documentos, de forma a preservar a metodologia e know-how da empresa de consultoria, com o objetivo de "esconder" o conhecimento técnico aplicado.

Os documentos analisados não possibilitam a análise do prazo envolvido apenas no desenvolvimento da Investigação Detalhada (ID) e Análise de Risco Toxicológico (ARtx), assim como no Plano de Intervenção (PI), pois não indicam a data de contratação do mesmo, apenas a data do relatório em si. Entretanto, a avaliação dos prazos indicados nas bibliografias avaliadas (Tabelas 4.2a e 4.2b), bem como informações verbais quando de discussão do trabalho com demais consultores, sugerem que a ID, ARtx são desenvolvidas ao longo de um período de 5 a 6 meses, sem considerar, no entanto, o tempo necessário para a aprovação e contratação das atividades subsequentes.

\subsubsection{Contexto hidrogeológico}

As áreas avaliadas situam-se, predominantemente, em contexto sedimentar (com 35 - trinta e cinco - dos casos, representando $79,6 \%$ do total das áreas) e, secundariamente, em contexto das rochas do embasamento cristalino. A Figura 5.3, anteriormente citada, ilustra a situação das áreas no contexto geológico do Estado de São Paulo. Em 2 (dois) dos casos, as sondagens de investigação, executadas até uma profundidade de 15 m, não interceptaram o nível de água subterrânea local.

A Tabela 5.2 apresenta o resumo das características hidrogeológicas médias das áreas investigadas. 
A análise dos relatórios técnicos das diversas etapas do Gerenciamento de Área Contaminada (GAC) indica que as sondagens de investigação apresentam uma descrição táctil visual simples dos litotipos que ocorrem na região investigada, com ênfase na descrição granulométrica composta (argila, silte e areia), representada pela granulometria principal associada a uma granulometria secundária: argila arenosa, areia siltosa, silte argiloso, etc.. A análise destas descrições indica a predominância de argilas arenosas $(47,7 \%)$ e areias argilosas (38,6 \%), conforme apresentado na Tabela 5.3.

A descrição litológica simplificada que usualmente é efetuada nos trabalhos dificulta quaisquer correlações entre a as características litológicas em função do contexto geológico, se sedimentar ou cristalino. Além da ocorrência do manto de alteração, que usualmente é descrito pela sua granulometria (argiloso, siltoso ou arenoso), os postos de combustíveis situam-se preferencialmente nas margens das grandes avenidas, e estas, usualmente estão em grande vales, em contexto local aluvionar (associado aos córregos) que se mistura a uma possível descrição do manto de alteração.

A análise da profundidade do nível da água subterrânea medida em 42 (quarenta e duas) das áreas estudadas, e, consequentemente, a espessura da zonas não saturadas, indica que a mesma está situada, em média, a 4,6 $\mathrm{m}$ de profundidade em relação à superfície (Gráfico 5.8), com gradiente hidráulico médio da superfície freática de 0,045 , variando de 0,005 a 0,130 (Gráfico 5.9), apresentando uma média ponderada de 0,056 . Em muitos dos relatórios analisados não constava a informação do gradiente hidráulico, sendo assim, para todos em que o mapa potenciométrico foi apresentado, bem como as cargas hidráulicas, este foi calculado pelo autor.

É possível distinguir uma tendência de maior profundidade do nível freático em contexto cristalino, situado a uma profundidade média de $5,47 \mathrm{~m}$ (da superfície do terreno) e 0,053 de gradiente hidráulico, em relação as áreas situadas em contexto sedimentar, com profundidade média de 4,43 m e um gradiente hidráulico de 0,046.

Entretanto, a baixa variação das características hidrogeológicas entre os contextos geológicos, com média do nível de água próxima aos 5,0 m em relação à superfície do terreno, sugere uma favorabilidade da aplicação das técnicas de remediação do dano reversível, tanto da zona não saturada como da saturada. 
Tabela 5.2 - Principais características hidrogeológicas médias das áreas investigadas.

\begin{tabular}{|c|c|c|c|c|c|c|c|}
\hline Sedimento & $\begin{array}{c}\text { Rocha } \\
\text { alterada }\end{array}$ & $\begin{array}{l}\text { Litotipos } \\
\text { Principais }\end{array}$ & $\begin{array}{l}\text { ZN Sat } \\
(\mathrm{m})\end{array}$ & $\begin{array}{l}\text { Gradiente } \\
\text { (i) }\end{array}$ & $\begin{array}{l}\text { Poros } \\
\text { Efet }\end{array}$ & $\begin{array}{l}\text { Vap } \\
\text { m/ano }\end{array}$ & K Med \\
\hline Sim & Não & ARG+ARE & 2.77 & 0.025 & & 0.39 & 5.00E-05 \\
\hline Sim & Não & ARG+ARE & 7.53 & 0.023 & & & \\
\hline Sim & Não & $A R E+A R G$ & & & & & \\
\hline Sim & Não & $A R E+A R G$ & 6.06 & 0.054 & & 6.18 & 3.60E-04 \\
\hline Sim & Não & $A R E+A R G$ & 2.00 & 0.045 & $10.0 \%$ & 1.46 & 1.04E-04 \\
\hline Sim & Não & $A R E+A R G$ & 7.00 & 0.033 & & & \\
\hline Sim & Não & ARG+ARE & 10.00 & 0.104 & & 3.27 & 1.00E-04 \\
\hline Sim & Não & ARG+ARE & 9.00 & 0.021 & & 0.84 & $1.25 \mathrm{E}-04$ \\
\hline Sim & Não & ARG+ARE & 1.10 & 0.009 & & 0.29 & $1.00 \mathrm{E}-04$ \\
\hline Sim & Não & ARG+ARE & 1.00 & 0.005 & & 0.76 & $5.00 \mathrm{E}-04$ \\
\hline Não & Sim & $A R G+A R E$ & 10.00 & 0.037 & & 5.79 & $5.00 \mathrm{E}-04$ \\
\hline Sim & Não & $A R E+A R G$ & 4.00 & 0.016 & & 2.49 & $5.00 \mathrm{E}-04$ \\
\hline Sim & Não & $A R E+A R G$ & 1.80 & 0.010 & $12.0 \%$ & 0.70 & $2.14 \mathrm{E}-04$ \\
\hline Sim & Não & ARG+ARE & 4.00 & 0.093 & $25.0 \%$ & 0.25 & 8.73E-06 \\
\hline Sim & Não & $A R E+A R G$ & 1.00 & 0.035 & $12.5 \%$ & 1.66 & $1.50 \mathrm{E}-04$ \\
\hline Não & Sim & ARG+ARE & 6.50 & 0.089 & $18.7 \%$ & 13.53 & $4.82 \mathrm{E}-04$ \\
\hline Sim & Não & ARG+ARE & & & & & \\
\hline Sim & Não & ARG+ARE & 1.30 & 0.051 & $6.0 \%$ & 2.96 & $1.83 \mathrm{E}-04$ \\
\hline Não & Sim & $A R E+A R G$ & 5.00 & 0.021 & $7.2 \%$ & 4.97 & 7.50E-04 \\
\hline Sim & Não & $A R G+A R E$ & 4.00 & 0.031 & & 0.42 & 4.30E-05 \\
\hline Sim & Não & $A R E+A R G$ & 3.00 & 0.031 & & 0.13 & 1.30E-05 \\
\hline Sim & Não & $A R E+A R G$ & 6.30 & 0.049 & & & \\
\hline Sim & Não & $A R E+A R G$ & 1.20 & 0.017 & & & \\
\hline Sim & Não & ARG+SILT & 2.70 & 0.034 & & & \\
\hline Sim & Não & $A R E+A R G$ & 9.10 & 0.055 & & & \\
\hline Não & Sim & SILT+ARG & 6.50 & 0.060 & $5.5 \%$ & 0.88 & 4.68E-05 \\
\hline Não & Sim & ARG+SILT & 11.00 & 0.070 & $27.5 \%$ & 1.15 & 5.21E-05 \\
\hline Sim & Não & ARG+SILT & 4.60 & 0.043 & & 6.73 & 4.96E-04 \\
\hline Sim & Não & SILT+ARG & 7.66 & 0.020 & $5.0 \%$ & 0.36 & 5.65E-05 \\
\hline Sim & Não & ARG+SILT & 7.50 & 0.061 & $6.1 \%$ & 0.57 & 2.97E-05 \\
\hline Sim & Não & $A R G+A R E$ & 7.47 & 0.098 & $13.0 \%$ & 3.85 & $1.24 \mathrm{E}-04$ \\
\hline Sim & Não & $A R G+A R E$ & 0.90 & 0.046 & $19.0 \%$ & 3.80 & $2.62 \mathrm{E}-04$ \\
\hline Sim & Não & ARG+ARE & 1.60 & 0.017 & $6.0 \%$ & 0.93 & 1.79E-04 \\
\hline Não & Sim & ARG+ARE & 3.80 & 0.090 & $11.2 \%$ & 1.97 & $6.95 \mathrm{E}-05$ \\
\hline Sim & Não & ARG+ARE & 2.50 & 0.040 & $5.9 \%$ & 6.59 & $5.23 \mathrm{E}-04$ \\
\hline Sim & Não & $A R E+A R G$ & 1.95 & 0.012 & $7.5 \%$ & 0.71 & 1.96E-04 \\
\hline Sim & Não & $A R G+A R E$ & 4.30 & 0.001 & $3.0 \%$ & 0.01 & 8.00E-05 \\
\hline Sim & Não & $A R E+A R G$ & 7.60 & 0.089 & $12.0 \%$ & 3.17 & 1.13E-04 \\
\hline Não & Sim & $A R G+A R E$ & 1.00 & 0.052 & $8.1 \%$ & 2.80 & $1.71 \mathrm{E}-04$ \\
\hline Sim & Não & $A R E+A R G$ & 6.00 & 0.036 & $9.1 \%$ & 0.26 & $2.29 \mathrm{E}-05$ \\
\hline Não & Sim & $A R G+A R E$ & 2.00 & 0.023 & $6.4 \%$ & 0.29 & 4.03E-05 \\
\hline Não & Sim & ARG+ARE & 3.40 & 0.036 & $6.4 \%$ & 0.82 & $7.26 \mathrm{E}-05$ \\
\hline Sim & Não & $A R E+A R G$ & 2.70 & 0.061 & $6.4 \%$ & 12.93 & $6.72 \mathrm{E}-04$ \\
\hline Sim & Não & $A R E+A R G$ & 6.50 & 0.130 & $8.6 \%$ & 0.59 & $1.44 \mathrm{E}-05$ \\
\hline
\end{tabular}

ARG - Argila; SILT - Silte; ARE - Areia; ZN Sat - Média da espessura da zona não saturada ou profundidade do nível de água; i-Gradiente hidráulico médio; Poros Efet - Porosidade efetiva; Vap Velocidade aparente do fluxo da água subterrânea; k Med - condutividade hidráulica média do terreno $(\mathrm{cm} / \mathrm{s})$. 
Tabela 5.3 - Principais composições litológicas verificadas nas áreas.

\begin{tabular}{|c|c|c|}
\hline COMPOSIÇÃO & N & $\%$ \\
\hline ARE+ARG & 17 & $38.64 \%$ \\
\hline ARG+ARE & 21 & $47.73 \%$ \\
\hline ARG+SILT & 4 & $9.09 \%$ \\
\hline SILT+ARG & 2 & $4.55 \%$ \\
\hline SILT+ARE & 0 & $0.00 \%$ \\
\hline ARE+SILT & 0 & $0.00 \%$ \\
\hline
\end{tabular}

ARE+ARG - Areia argilosa; ARE+SILT - Areia siltosa; ARG+ARE-Argila arenosa; ARG+SILT Argila siltosa; SILT+ARE - Silte arenoso; SILT+ARG - Silte argiloso; $\mathbf{N}$ - Número de ocorrência.

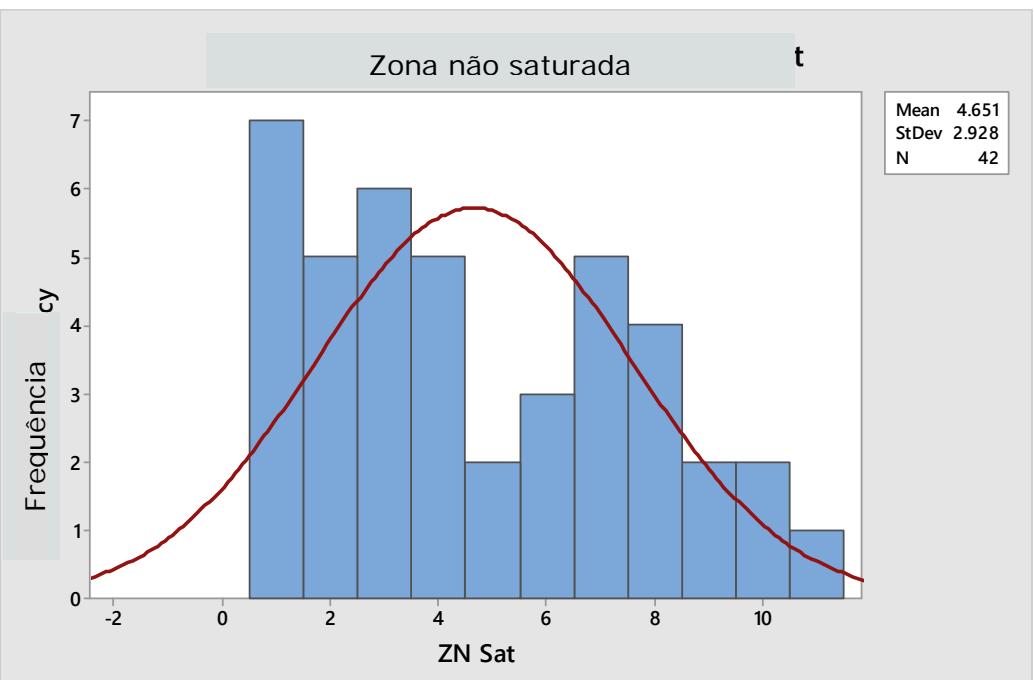

Gráfico 5.8 - Histograma da variação da espessura da zona não saturada ou profundidade do nível de água nas áreas avaliadas.

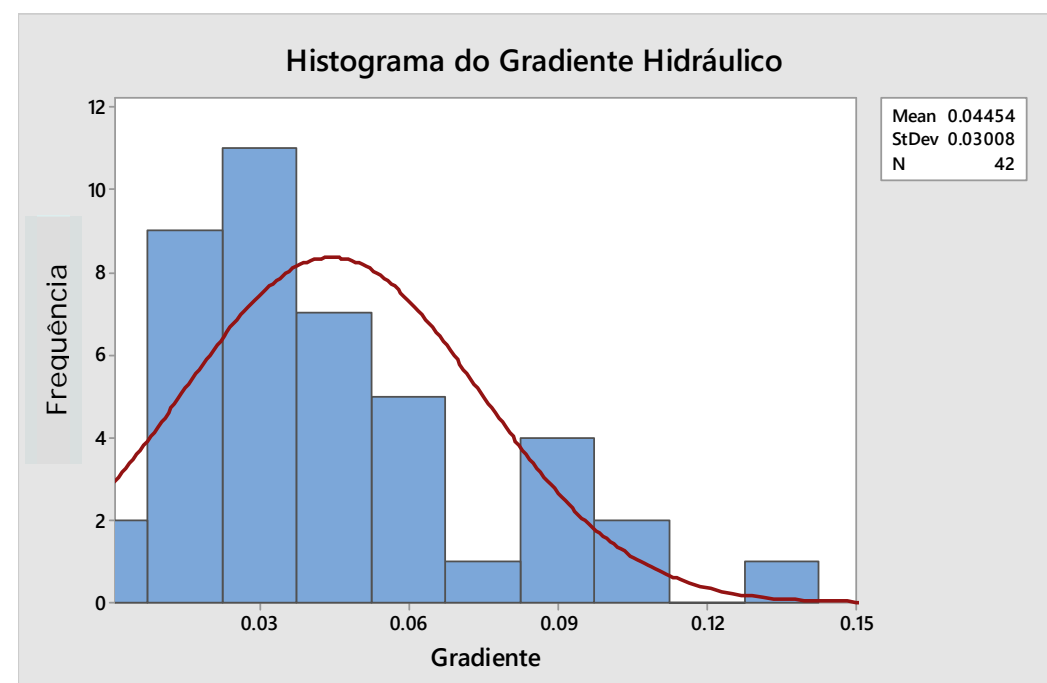

Gráfico 5.9 - Histograma da variação do gradiente hidráulico da superfície freática da água subterrânea nas áreas avaliadas.

\section{ANÁLISE ESTATÍSTICA}

Espessura da zona não saturada

(m)

Média $=4,6$

Erro padrão = 0,5

Desvio padrão $=2,9$

Mediana $=\quad 4,0$

$\mathrm{N}^{\circ}$ amostras $=$
ANÁLISE ESTATÍSTICA

Variação do gradiente hidráulico (i)

Média $=0,0445$

Erro padrão $=0,0046$

Desvio padrão $=\quad 0,0301$

Mediana $=$ 0,0363

$\mathrm{N}^{0}$ amostras $=$ 42 
As diferenças observadas dos gradientes hidráulicos e das profundidades do nível de água se explicam pela tendência a existirem elevações suaves no domínio das rochas sedimentares, e, mais fortes, em terrenos do cristalino, originando menores desníveis em relação as drenagens locais no contexto sedimentar e, consequentemente, menores gradientes hidráulicos das águas subterrâneas e profundidade do nível de água em setores mais distantes das drenagens.

A porosidade efetiva foi determinada em 25 (vinte e cinco) das 44 (quarenta e quatro) áreas avaliadas, representando um índice de 56,8 \% das vezes, ocorrência menor do que o esperado, pois $86,4 \%$ das áreas cadastradas desenvolveram etapas posteriores à Investigação Confirmatória (IC), e, com necessidade de haver a aquisição desta informação durante os trabalhos de investigação.

Entretanto os dados existentes nos relatórios avaliados indicam uma porosidade efetiva média de 10,3\%, com erro de 1,2 \% e desvio padrão de 6,2 \% para o solo superficial no Estado de São Paulo, conforme apresentado no Gráfico5.10.Por outro lado, a análise das condutividade hidráulicas médias constantes em 36 (trinta e seis) dos relatórios avaliados, obtidas através de ensaios in situ, indica uma média de $2,06 \mathrm{E}^{-4} \mathrm{~cm} / \mathrm{s}$, conforme ilustra o Gráfico 5.11 .

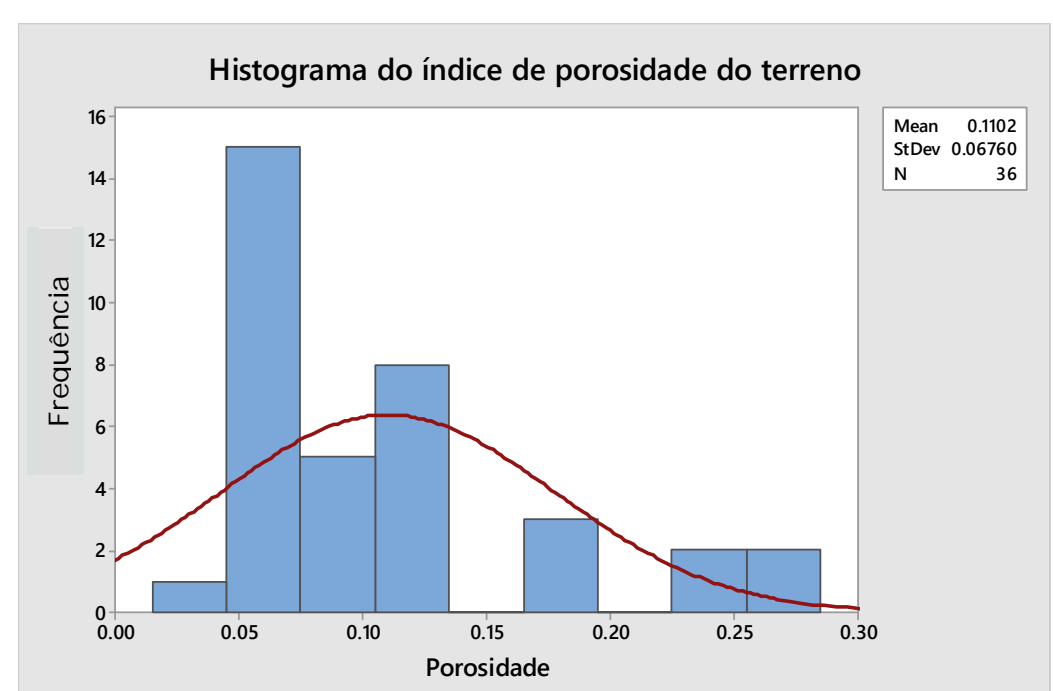

Gráfico 5.10 - Histograma da variação da porosidade efetiva nas áreas avaliadas.

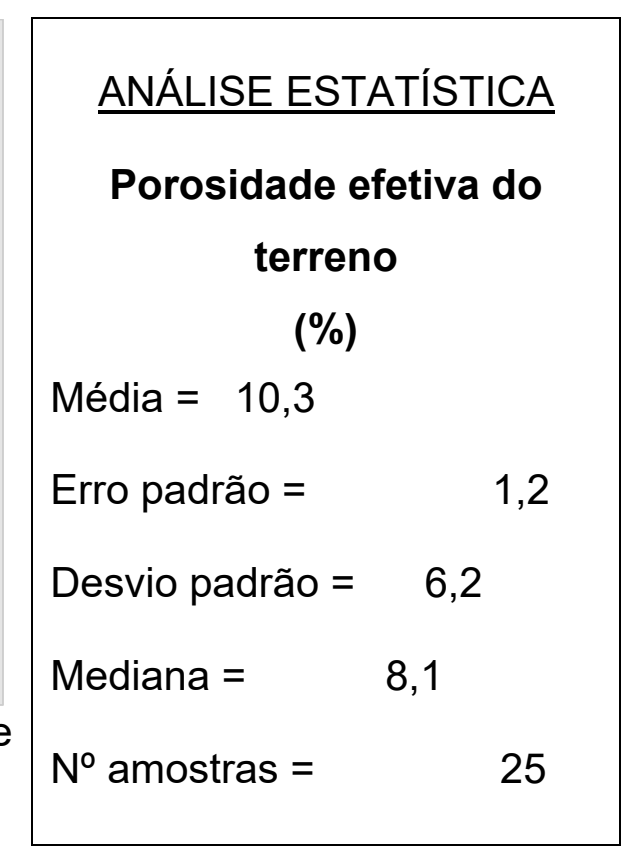




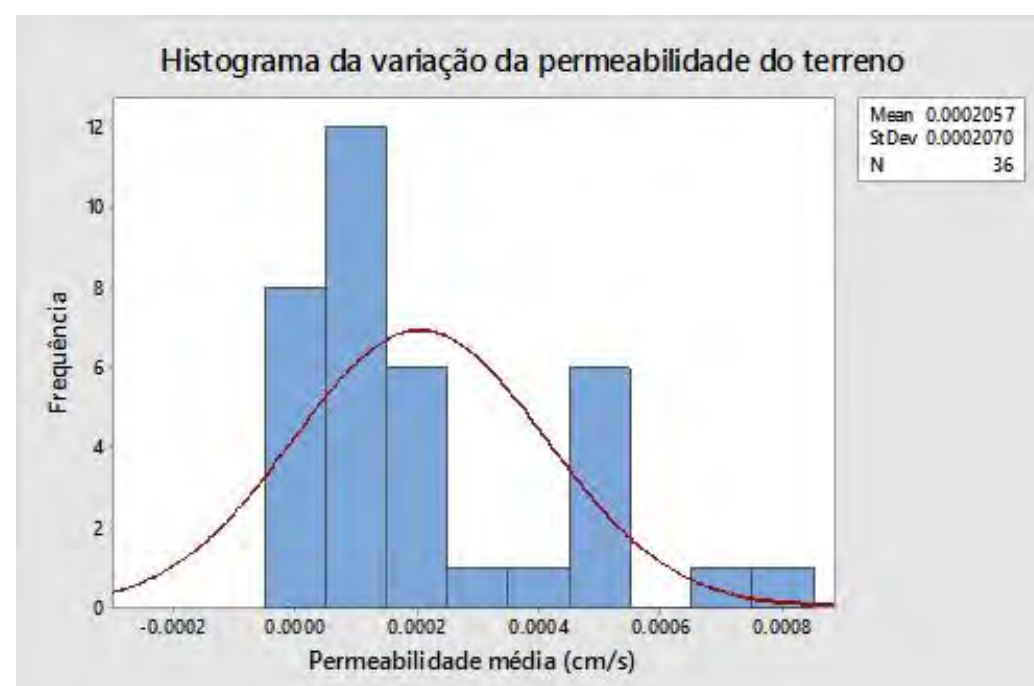

Gráfico 5.11 - Histograma da variação da condutividade hidráulica obtidas em ensaios in situ.
ANÁLISE ESTATÍSTICA

Condutividade do terreno K (cm/s)

Média $=0,000206$

Erro padrão $=0,000035$

Desvio padrão $=0,000207$

Mediana $=\quad 0,000119$

$\mathrm{N}^{\circ}$ amostras $=\quad 36$

Os dados indicam uma baixa variação da condutividade hidráulica média em função do contexto geológico (Gráfico 5.12), com condutividade hidráulica média do terreno de $2,4 \mathrm{E}^{-4} \mathrm{~cm} / \mathrm{s}$ em contexto das rochas cristalinas $e$, $1,9 \mathrm{E}^{-4} \mathrm{~cm} / \mathrm{s}$, no contexto das rochas sedimentares.

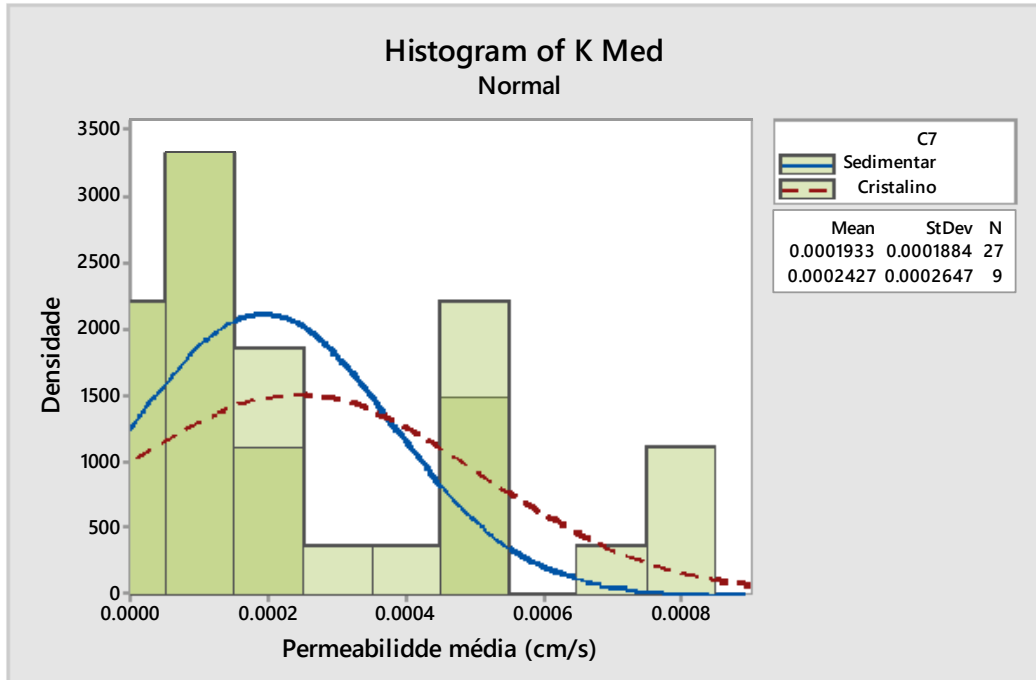

Gráfico 5.12 - Histograma da variação da condutividade hidráulica obtidas em ensaios in situ.

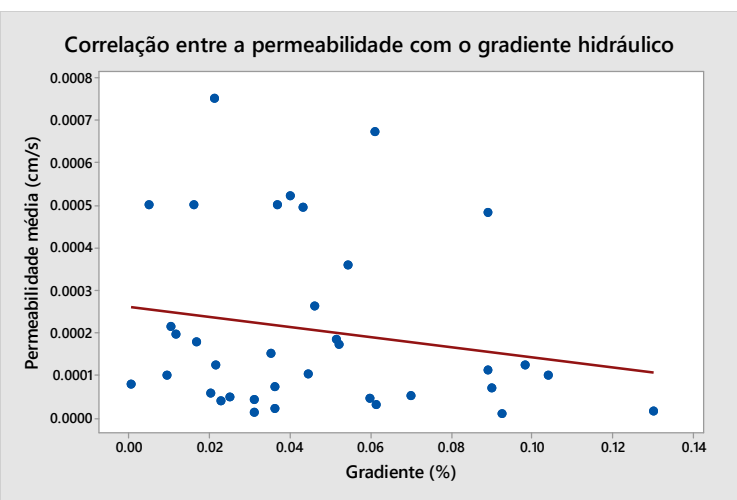

Gráfico 5.13 - Correlação entre a condutividade hidráulica e o gradiente hidráulico das áreas avaliadas.
Existe a tendência de, quanto maior a condutividade hidráulica média do terreno, menor o gradiente hidráulico (Gráfico 5.13), pois o aumento da condutividade hidráulica facilita o deslocamento da água no subsolo e sua busca pelo equilíbrio das cargas hidráulicas, a ser obtido com a proximidade do gradiente hidráulico nulo. 
Considerando que o objetivo desta tese é definir uma metodologia de valoração da investigação e remediação do dano ambiental logo após a IC, quando, ainda não ocorre, usualmente, a determinação da porosidade, para a avaliação do fluxo de água subterrânea foi considerada a velocidade aparente de fluxo (Vap), conforme dada pela Lei de Darcy (ano de 1856). Apesar da Lei de Darcy não expressar o comportamento do fluido em um meio poroso, apenas sua descrição macroscópica do fenômeno em regime laminar, considerando que o líquido percola de forma uniforme por toda a seção normal à direção do fluxo, sem discriminar sólidos e vazios, sua aplicação é amplamente utilizada, sendo expressa pela Equação 5.1.

\section{Equação 5.1:}

$$
V a p=k \times i=k \times \frac{\Delta h}{\Delta s}[\text { Equação 5.1] }
$$

Onde:

k - Coeficiente de condutividade hidráulica $(\mathrm{m} / \mathrm{s})$.

$\mathrm{i}=$ Gradiente hidráulico.

$\Delta \mathrm{h}=$ Variação da cota (carga hidráulica) entre os pontos de medição (m).

$\Delta \mathrm{s}=$ Variação da distância entre os pontos de medição $(\mathrm{m})$.

Assim sendo, foi calculada a Vap da água subterrânea nas áreas (Tabela 5.2) e a análise estatística dos resultados indica um deslocamento médio de 2,54 m/ano da água, conforme ilustra o Gráfico 5.14.

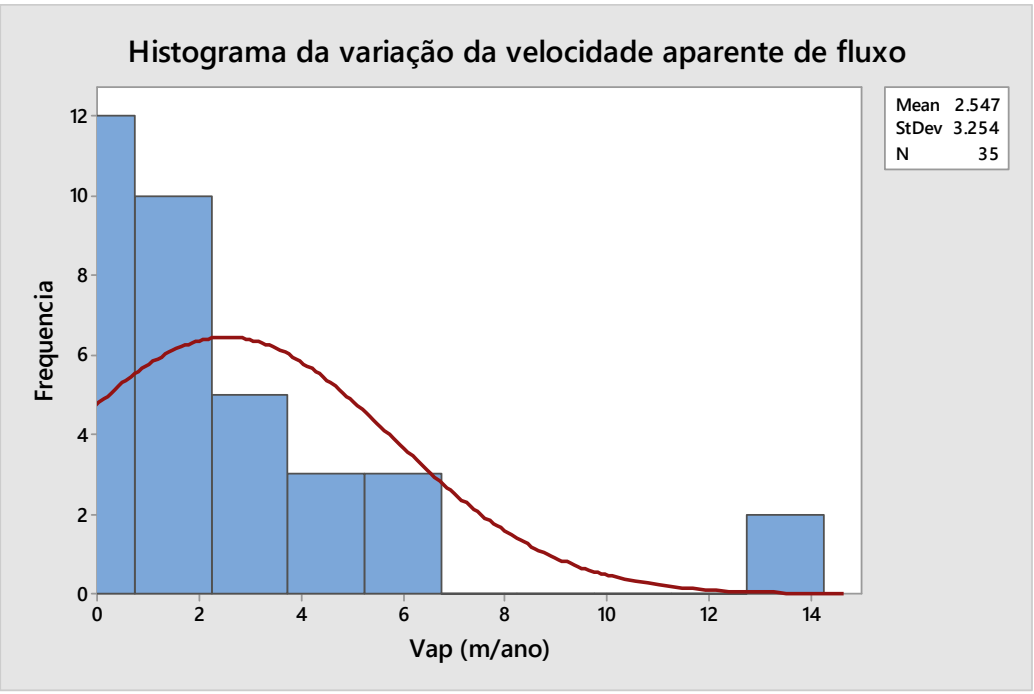

Gráfico 5.14 - Histograma da variação da velocidade aparente (Vap) da água subterrânea.

ANÁLISE ESTATÍSTICA

Velocidade aparente da água subterrânea (Vap) (m/ano)

Média $=2,54$

Erro padrão $=0,550$

Desvio padrão $=3,254$

Mediana $=$ 1,054 $\mathrm{N}^{0}$ amostras $=$ 35 


\subsubsection{Investigação da ocorrência do contaminante}

A principal ferramenta de planejamento da investigação ambiental de uma área é a Avaliação Preliminar (AvP), onde são definidas as fontes potenciais de contaminação, sejam Áreas Suspeitas (AS) ou Potenciais (AP), assim como as Substâncias Químicas de Interesse (SQI), entre outros fatores.

Os relatórios ambientais analisados indicam uma deficiência do levantamento inicial das áreas, devido à ausência de informações disponíveis quando da execução dos trabalhos ou por qualquer outro fator. Assim, não é possível fazer distinção nas metodologias de investigação (ou seus quantitativos) em função das características distintas da área investigada.

Os dados de investigação das áreas contaminadas cadastradas foram analisados de forma a definir um padrão de referência para os trabalhos de investigação do dano ambiental. A Tabela 5.4 apresenta os principais parâmetros de investigação consolidados para as 44 (quarenta e quatro) áreas analisadas, avaliadas nos subitens subsequentes.

\subsubsection{Investigação da fase vapor}

Não se verificou, em nenhum dos trabalhos avaliados, nenhuma investigação específica para a avaliação da fase vapor, ou intrusão de vapor nas áreas investigadas. Verificou-se, apenas, o desenvolvimento da investigação do tipo Soil Gas Survey (SGS) para fins de planejamento da investigação e o monitoramento das concentrações de compostos orgânicos voláteis (VOC) em fase vapor durante as atividades de remediação que envolviam a diminuição da massa contaminante em fase vapor. Os pontos de monitoramento da fase vapor usualmente se limitavam aos pontos de extração de vapor (quando da remediação) ou dos poços de monitoramento da água subterrânea.

Assim, salvo os poços de extração de vapor, específicos para as ações de remediação, não se observou a instalação de dispositivos para a investigação da fase vapor em nenhuma das áreas avaliadas. 
Tabela 5.4 - Quantitativos de investigação, ensaios, sondagens e instalação de poços, consolidados por área investigada avaliadas nesta tese.

\begin{tabular}{|c|c|c|c|c|c|c|c|c|c|c|c|c|c|c|}
\hline \multirow{3}{*}{ 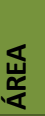 } & \multirow{3}{*}{$\begin{array}{c}\text { DADOS } \\
\text { Área } \\
\text { m2 }\end{array}$} & \multirow{3}{*}{$\begin{array}{c}\text { ZN Sat } \\
(\mathrm{m})\end{array}$} & \multirow{3}{*}{$\begin{array}{c}\text { Ensaio } \\
\text { K } \\
\text { Quant }\end{array}$} & \multicolumn{2}{|c|}{ SGS } & \multicolumn{3}{|c|}{ Sondagem } & \multicolumn{6}{|c|}{ Poço de monitoramento } \\
\hline & & & & & Pontos & & & & PN & & PM Pro & REM & PN & \\
\hline & & & & Ptos & m2 & Quant & (m) & $\mathrm{S} / \mathrm{m} 2$ & Quant & $(\mathrm{m})$ & Quant & $(\mathrm{m})$ & Quant & (m) \\
\hline 1 & 258.5 & 2.8 & & 13 & 0.104 & & & & & & & & & \\
\hline 2 & $1,500.0$ & 7.5 & & 13 & 0.068 & & & & & & & & & \\
\hline 3 & $1,500.0$ & 7.5 & & 17 & 0.027 & & & & & & & & & \\
\hline 4 & $2,500.0$ & 6.1 & & 12 & 0.024 & 25 & 191 & 0.050 & 15 & 121 & 0 & 0 & 5 & 65 \\
\hline 5 & $1,200.0$ & 2.0 & 4 & & & 19 & 101 & 0.162 & 17 & 85 & 0 & 0 & 2 & 16 \\
\hline 6 & 690.0 & 7.0 & & & & 38 & 372 & 0.169 & 27 & 288 & 1 & 12 & 4 & 48 \\
\hline 7 & $1,300.0$ & 10.0 & 4 & & & 44 & 528 & 0.845 & 41 & 492 & 3 & 45 & 0 & 0 \\
\hline 8 & 600.0 & 9.0 & 5 & & & 31 & 341 & 0.086 & 26 & 286 & 0 & 0 & 3 & 48 \\
\hline 9 & $1,280.0$ & 1.1 & & & & 43 & 155 & 0.141 & 34 & 105 & 7 & 35 & 2 & 14 \\
\hline 10 & $9,000.0$ & 1.0 & & 450 & 0.094 & 66 & 198 & 0.014 & 108 & 324 & 0 & 0 & 4 & 32 \\
\hline 11 & 916.0 & 10.0 & & & & 29 & 416 & 0.594 & 22 & 264 & 7 & 119 & 0 & 0 \\
\hline 12 & 916.5 & 4.0 & & & & 68 & 360 & 0.077 & 44 & 264 & 0 & 0 & 6 & 60 \\
\hline 13 & $1,135.0$ & 1.8 & & & & 62 & 248 & 0.529 & 34 & 129 & 4 & 15 & 3 & 23 \\
\hline 14 & 450.0 & 4.0 & & 10 & 0.063 & 22 & 85 & 0.138 & 8 & 42 & 0 & 0 & 0 & 0 \\
\hline 15 & $1,064.0$ & 1.0 & & & & 12 & 35 & 0.144 & 10 & 29 & 0 & 0 & 2 & 14 \\
\hline 16 & $9,000.0$ & 6.5 & & 24 & 0.035 & 33 & 241 & 0.048 & 9 & 30 & 0 & 0 & 0 & 0 \\
\hline 17 & 770.0 & 1.3 & & & & & & & & & & & & \\
\hline 18 & 700.0 & 1.3 & 7 & & & 21 & 52 & 0.042 & 8 & 25 & 6 & 20 & 0 & 0 \\
\hline 19 & $20,000.0$ & 5.0 & & & & & & & & & & & & \\
\hline 20 & 907.0 & 4.0 & 3 & & & 12 & 72 & 0.031 & 9 & 54 & 0 & 0 & 1 & 10 \\
\hline 21 & 252.0 & 3.0 & 3 & & & 16 & 80 & 0.547 & 10 & 50 & 0 & 0 & 1 & 9 \\
\hline 22 & $1,250.0$ & 6.3 & & & & 26 & 216 & 0.076 & 15 & 125 & 0 & 0 & 3 & 37 \\
\hline 23 & 920.0 & 1.2 & & & & 23 & 74 & 0.186 & 20 & 64 & 2 & 7 & 1 & 7 \\
\hline 24 & 380.0 & 2.7 & & & & 46 & 111 & 0.383 & 22 & 190 & 5 & 24 & 3 & 28 \\
\hline 25 & 300.0 & 8.2 & & & & 54 & 533 & 1.481 & 34 & 370 & 15 & 153 & 4 & 60 \\
\hline 26 & $8,000.0$ & 6.5 & 4 & & & 20 & 170 & 0.015 & 9 & 170 & 0 & 0 & 0 & 0 \\
\hline 27 & $1,690.0$ & 11.0 & 4 & & & 9 & 114 & 0.288 & 8 & 54 & 1 & 14 & 0 & 0 \\
\hline 28 & $1,280.0$ & 5.0 & 2 & 32 & 0.305 & 30 & 189 & 0.286 & 10 & 65 & 20 & 124 & 0 & 0 \\
\hline 29 & $2,000.0$ & 7.5 & 9 & & & 31 & 295 & 0.621 & 22 & 295 & 0 & 0 & 4 & 0 \\
\hline 30 & $3,000.0$ & 7.5 & 4 & 40 & 0.067 & 17 & 163 & 0.028 & 13 & 163 & 2 & 96 & 0 & 0 \\
\hline 31 & 600.0 & 8.2 & 11 & 13 & 0.074 & 35 & 334 & 1.910 & 20 & 334 & 11 & 109 & 0 & 0 \\
\hline 32 & $2,700.0$ & 0.9 & 3 & 38 & 0.094 & 24 & 93 & 0.059 & 14 & 39 & 4 & 10 & 6 & 44 \\
\hline 33 & 750.0 & 1.6 & 3 & 21 & 0.090 & 46 & 110 & 0.471 & 16 & 58 & 3 & 11 & 2 & 17 \\
\hline 34 & 777.0 & & & & & 11 & 41 & 0.094 & 5 & 29 & 0 & 0 & 0 & 0 \\
\hline 35 & 500.0 & 2.5 & 8 & & & 35 & 108 & 0.292 & 12 & 51 & 3 & 13 & 3 & 27 \\
\hline 36 & $13,250.0$ & 1.9 & 19 & 49 & 0.015 & 58 & 235 & 0.018 & 44 & 174 & 10 & 35 & 3 & 25 \\
\hline 37 & $46,000.0$ & 4.3 & 2 & & & 13 & 87 & 0.577 & 11 & 67 & 0 & 0 & 2 & 20 \\
\hline 38 & 700.0 & & 4 & & & 21 & 125 & 0.174 & 10 & 96 & 1 & 9 & 0 & 0 \\
\hline 39 & $1,050.0$ & 1.0 & 7 & 23 & 0.110 & 43 & 81 & 0.387 & 13 & 35 & 2 & 6 & 2 & 14 \\
\hline 40 & 600.0 & 6.0 & & & & 14 & 105 & 0.140 & 14 & 105 & 0 & 0 & 0 & 0 \\
\hline 41 & $1,000.0$ & 2.0 & 4 & 22 & 0.098 & 14 & 70 & 0.312 & 5 & 21 & 7 & 29 & 1 & 8 \\
\hline 42 & $1,600.0$ & 3.4 & 4 & 27 & 0.060 & 17 & 91 & 0.038 & 13 & 69 & 4 & 22 & 0 & 0 \\
\hline 43 & $1,750.0$ & 2.3 & 4 & & & 34 & 114 & 0.183 & 10 & 38 & 0 & 0 & 1 & 52 \\
\hline 44 & 350.0 & 6.5 & 3 & & & 31 & 211 & 0.270 & 18 & 149 & 6 & 50 & 1 & 13 \\
\hline
\end{tabular}

Área $\mathbf{m} 2$ - Área do posto em metros quadrados; ZN Sat - Média da espessura da zona não saturada ou profundidade do nível de água; Ensaio $\mathbf{K}$ - Número de ensaio de condutividade hidráulica in situ; SGS Pts - Número de pontos de Soil Gas Survey; Quant - Quantidade do item; (m) - Metragem total da sondagem ou do poço; s/m2 - Número de sondagem por metro quadrado da área; PMR - Poço de monitoramento raso; PM Prov I REM - Poços de monitoramento provisório ou do sistema de remediação; PMN - Poço de monitoramento multinível; SGS - Soil Gas Survey. 
O SGS foi desenvolvido em apenas 17 (dezessete) das 44 (quarenta e quatro) áreas analisadas, em malhas com espaçamento variando de 2,5 a 10,0 m, gerando uma razão média de 0,08 ponto de medição por metro quadrado de área investigada. Este índice representa, assim, um ponto de leitura de cerca de $12,5 \mathrm{~m}^{2}$, ou uma malha regular de 3,5 × 3,5 m, aproximadamente. Entretanto, este índice de pontos por metro quadrado é conservador, uma vez que a área total considera a área edificada ou com equipamentos instalados, áreas estas, usualmente não medidas na malha de SGS.

Os dados existentes não possibilitaram caracterizar uma influência direta da metodologia do SGS na eficiência da investigação de área, pois, em muitos dos 17 (dezessete) casos, a mesma somente foi aplicada quando da execução de uma segunda (ou terceira) Investigação Detalhada (ID). Entretanto, dos 5 casos cadastrados em que não foi necessário o desenvolvimento de etapas posteriores à Investigação Confirmatória (IC), 3 (três) deles efetuaram o SGS, sugerindo uma melhor qualidade das informações da investigação direta, quando planejada conforme resultado obtido na SGS.

\subsubsection{Investigação da fase retida}

Os trabalhos evidenciam uma baixa preocupação com o mapeamento da fase retida (fase livre retida presente nos poros na zona não saturada), efetuando-se, usualmente, apenas a descrição organoléptica da amostra e a coleta e análise química do solo nos pontos em que ocorre evidência da presença de produto retida ou em pontos associados à instalação dos poços de monitoramento que, por sua vez, visam a delimitação da pluma de fase dissolvida.

Verificou-se, nos trabalhos analisados, do total de 341 (trezentos e quarenta e uma) etapas de Gerenciamento de Área Contaminada (GAC), em apenas 17 (dezessete) delas ocorreu a execução de sondagens de investigação com coleta de solo para análises da fase retida superior a de coleta de água subterrânea, razão esta que evidenciaria a existência de sondagens específicas para a coleta do solo com o objetivo do mapeamento da fase retida. 
Entretanto, dos 17 (dezessete) casos, apenas 3 (três) não estão associados ao controle da remoção da fonte de contaminação, sugerindo assim, que nestas áreas (6,8\% do total das áreas) foram efetuadas sondagens de investigação com o objetivo de coleta de amostras de solo para delimitação da fase retida.

Os dados existentes das etapas de GAC não possibilitaram uma distinção entre a sondagem executada para fins de investigação do terreno (caracterização da geologia e coleta de amostras) e a sondagem executada para dimensionamento ou operação da remediação, pois os resultados em si, se misturam.

Para a avaliação do número de sondagens de investigação desenvolvidas em uma área contaminada por combustíveis fósseis a partir da investigação Confirmatória (IC), não foram utilizadas as informações que apenas desenvolveram a IC e considerou-se que:

- A área do sistema de abastecimento (tanques subterrâneos, linhas e bombas de abastecimento) é uma única área fonte de contaminação.

- Toda a sondagem executada na área é de investigação, uma vez que sempre fornece informação ao conhecimento hidrogeológico ambiental do local.

- As perfurações executadas durante o Soil Gas Survey (SGS) não são sondagens de investigação.

Os resultados indicam uma média de 31 (trinta e uma) sondagens executadas por área investigada (Gráfico 5.15), com profundidades variando em função de seu objetivo:

a) Investigação da zona não saturada - sondagem executada até o nível freático local.

b) Para instalação de poço de monitoramento raso - sondagem executada até 2,0 m abaixo do nível freático local.

c) Para instalação de poço de monitoramento multinível - sondagem executada até 10,0 m abaixo do nível freático local.

Assim, o principal condicionante da profundidade das sondagens executadas durante uma investigação de área contaminada por combustíveis fósseis é a profundidade do nível de água freático local. 


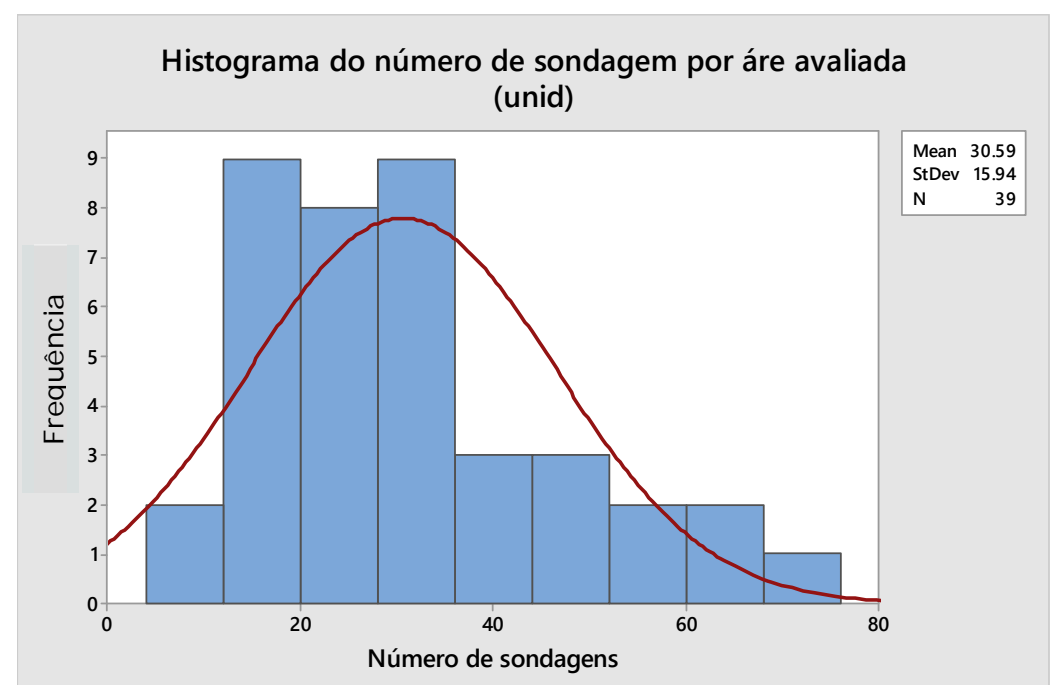

Gráfico 5.15 - Histograma do número de sondagem executada por área avaliada nessa tese.
ANÁLISE ESTATÍSTICA

Número de sondagem por área investigada

(unidade)

Média $=$ 30,59

Erro padrão $=2,55$

Desvio padrão $=\quad 15,94$

Mediana $=\quad 29,00$

$\mathrm{N}^{0}$ amostras $=$

\subsubsection{Investigação da fase livre e dissolvida}

Os dados indicam a instalação, em média, de 20 (vinte) poços de monitoramento rasos (PMR) conforme análise estatística apresentada no Gráfico 5.16, com profundidade média de 7,0 m (Gráfico 5.17). Considerando-se a espessura média da zona não saturada de 4,6 m, verifica-se que os poços rasos são instalados com sua base 2,4 m abaixo do nível de água subterrânea identificado. Esta correlação de profundidade do poço raso com o nível de água é bem evidenciada no Gráfico 5.18, onde é apresentada a correlação direta entre os parâmetros.

Por outro lado os poços de monitoramento multiníveis (PMN) apresentam uma média de 2 (dois) poços instalados por área investigada, mas com um desvio padrão de mesma grandeza de sua média (Gráfico 5.19). Assim como os PMRs, os PMNs apresentam boa correlação de sua profundidade média com a profundidade do nível de água local (Gráfico 5.18), sendo instalado, em média, 10,4 m abaixo do nível de água subterrânea, representando uma profundidade total média de $15 \mathrm{~m}$. 


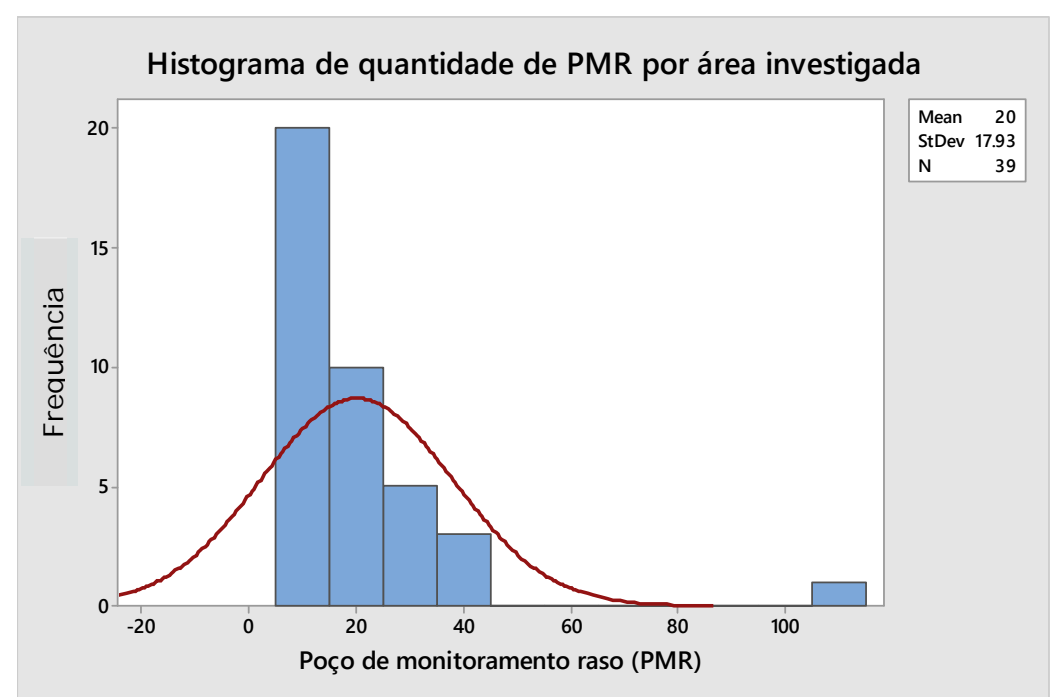

Gráfico 5.16 - Histograma do número de poços rasos (PMR) instalados por área avaliada nessa tese.

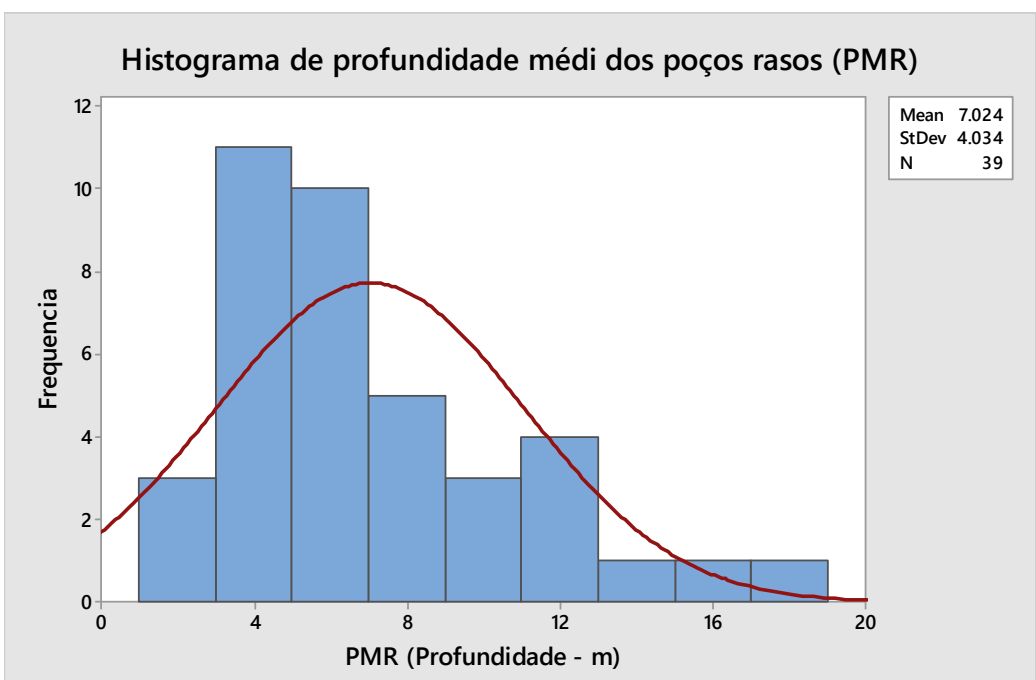

Gráfico 5.17 - Histograma de profundidade dos poços de monitoramento rasos (PMR).

\section{ANÁLISE ESTATIISTICA}

Número de poços rasos instalados por área investigada

(unidade)

Média $=20,00$

Erro padrão $=2,87$

Desvio padrão $=\quad 17,93$

Mediana $=$ 14,00

$\mathrm{N}^{\circ}$ amostras $=$ 39

\section{ANÁLISE ESTATÍSTICA}

Profundidade média dos poços rasos instalados.

(m)

Média $=7,02$

Erro padrão $=0,65$

Desvio padrão $=$ 4,03

Mediana $=$ 6,00

$\mathrm{N}^{\circ}$ amostras $=$ 


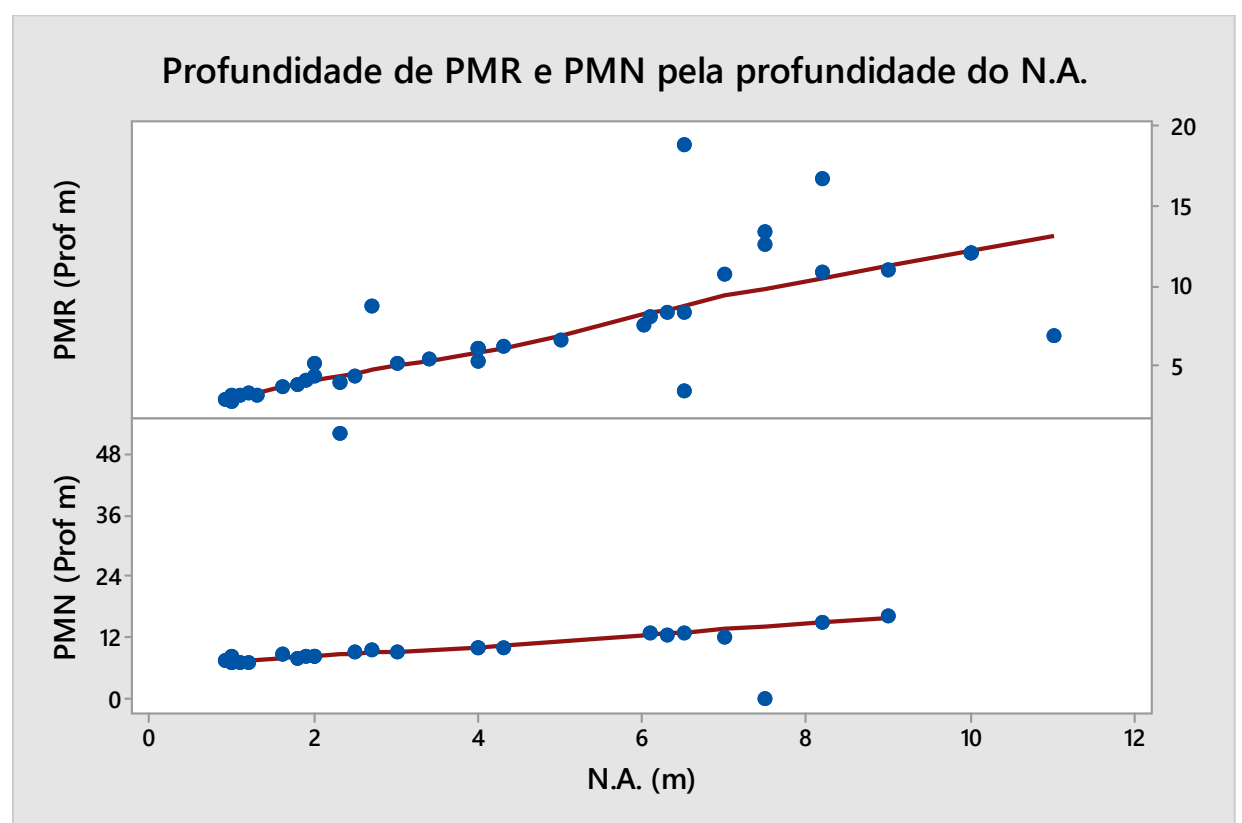

Gráfico 5.18 - Correlação da profundidade dos poços rasos (PMR) e multiníveis (PMN) com a profundidade do nível de água nas áreas avaliada nessa tese.

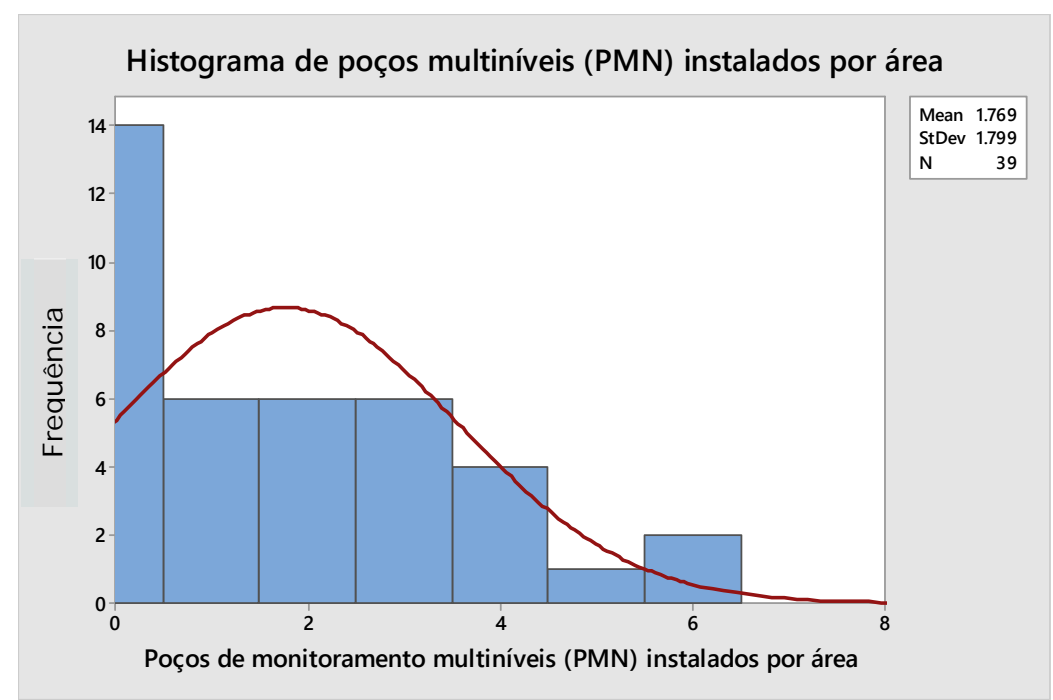

Gráfico 5.19 - Histograma de quantidade de poços de monitoramento multiníveis (PMN) instalados por área avaliada nessa tese.

\section{ANÁLISE ESTATÍSTICA}

Número de poços multiníveis instalados por área investigada (unidade)

Média $=$ 1,8

Erro padrão $=0,29$

Desvio padrão = 1,78

Mediana $=$ 1,0

$\mathrm{N}^{0}$ amostras $=$ 
5.4.2.4 Ensaios de caracterização física do meio

Em apenas 24 (vinte e quatro) das áreas avaliadas apresentaram o valor da condutividade hidráulica (k) média do terreno, foi possível identificar o número de ensaios efetuados. Em 12 (doze) destas áreas, apenas constavam a condutividade média sem maiores informações. Os relatórios, sem exceção, não correlacionam as condutividades obtidas nos ensaios com o litotipo predominante na profundidade dos filtros dos poços ensaiados, muito menos em relação a sua distribuição na área.

Os registros indicam uma média de5 (cinco) ensaios de condutividade in situ em cada área analisada, conforme ilustra o Gráfico 5.20.

Já em relação aos ensaios geotécnicos, efetuados em laboratório com amostras indeformadas, apenas foi possível caracterizar o número de ensaios efetuados em quatro áreas sendo que, em três das áreas efetuou-se apenas uma caracterização geotécnica e, em uma área, dois ensaios.

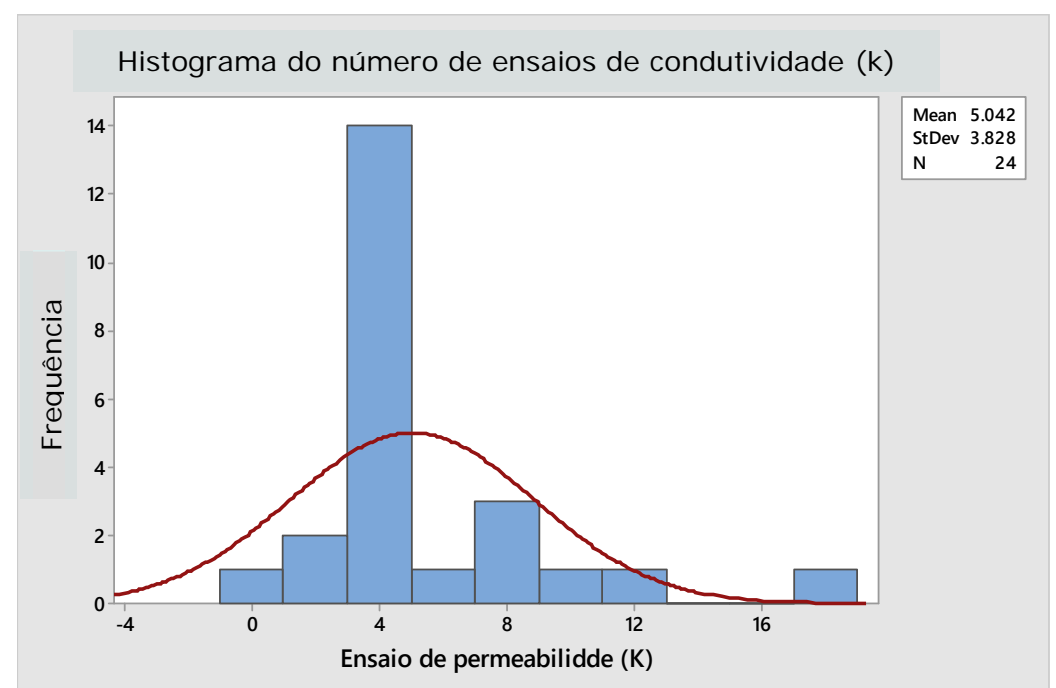

Gráfico 5.20 - Histograma de quantidade de ensaios de condutividade hidráulica realizados por área investigada.

\begin{tabular}{|}
$\begin{array}{l}\text { ANÁLISE ESTATÍSTICA } \\
\text { Número de ensaios de } \\
\text { condutividade executado } \\
\text { por área investigada } \\
\text { (unidade) }\end{array}$ \\
Média = 5,0 \\
Erro padrão = 0,78 \\
Desvio padrão = 3,83 \\
Mediana = 4,0 \\
No amostras = 24
\end{tabular}


5.4.2.5 Coleta e análises de amostras

Os registros indicam que são efetuadas, em média, 25 amostras de solo por área investigada, conforme ilustra o Gráfico 5.21. Entretanto, conforme indicado anteriormente, os registros evidenciam um pequeno número de sondagens específicas para a coleta de amostras de solo de caracterização da fase retida. $O$ autor observou que as coletas de solo são efetuadas, essencialmente, durante as sondagens de instalação de poços de monitoramento rasos. Essa conexão é evidenciada pelo Gráfico $\mathbf{5 . 2 2}$ de correlação entre o número de amostras de solo coletadas e os de poços de monitoramento rasos (PMR) instalados.

Por outro lado, considerando-se o número de amostras de água (subterrânea) por área investigada, verifica-se uma média de 125 (cento e vinte e cinco) coletas ao longo de todas as campanhas de GAC, a partir da Investigação Detalhada (ID), conforme apresentado no Gráfico $\mathbf{5 . 2 3}$.

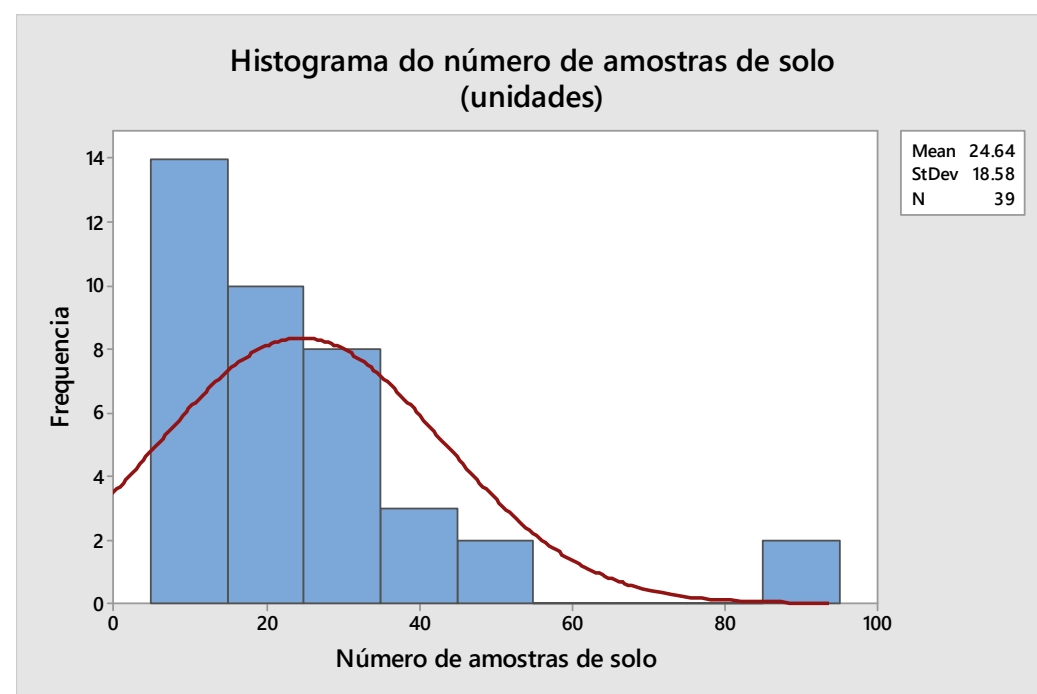

Gráfico 5.21 - Histograma do número de coleta de amostra de solo por área investigada.

\section{ANÁLISE ESTATÍSTICA}

Número de coleta de amostra de solo por área investigada (unidade)

Média $=\quad 25$

Erro padrão $=2,98$

Desvio padrão $=\quad 18,58$

Mediana $=$ 17,0

$\mathrm{N}^{\circ}$ amostras $=$ 
Número de coleta amostras de solo pelo de poços rasos instalados

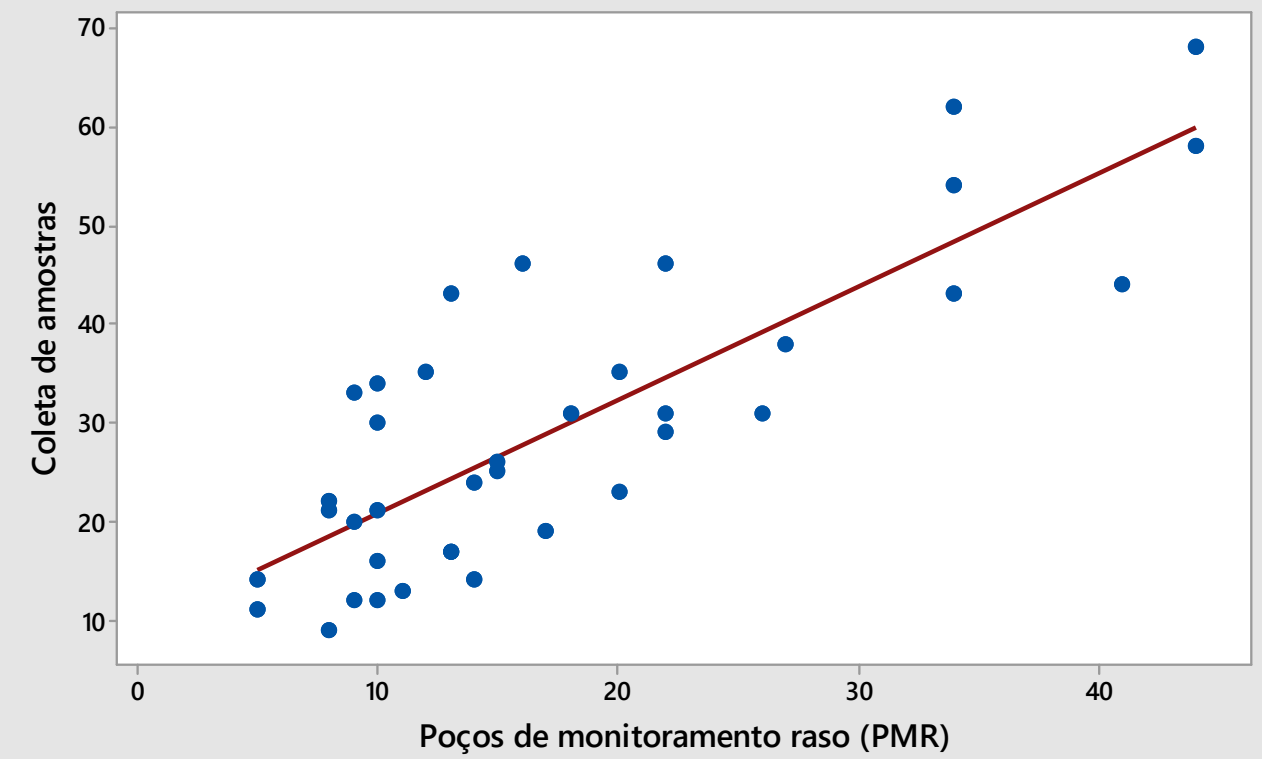

Gráfico 5.22 - Correlação do número de amostras de solo com o número de poços instalados na área.

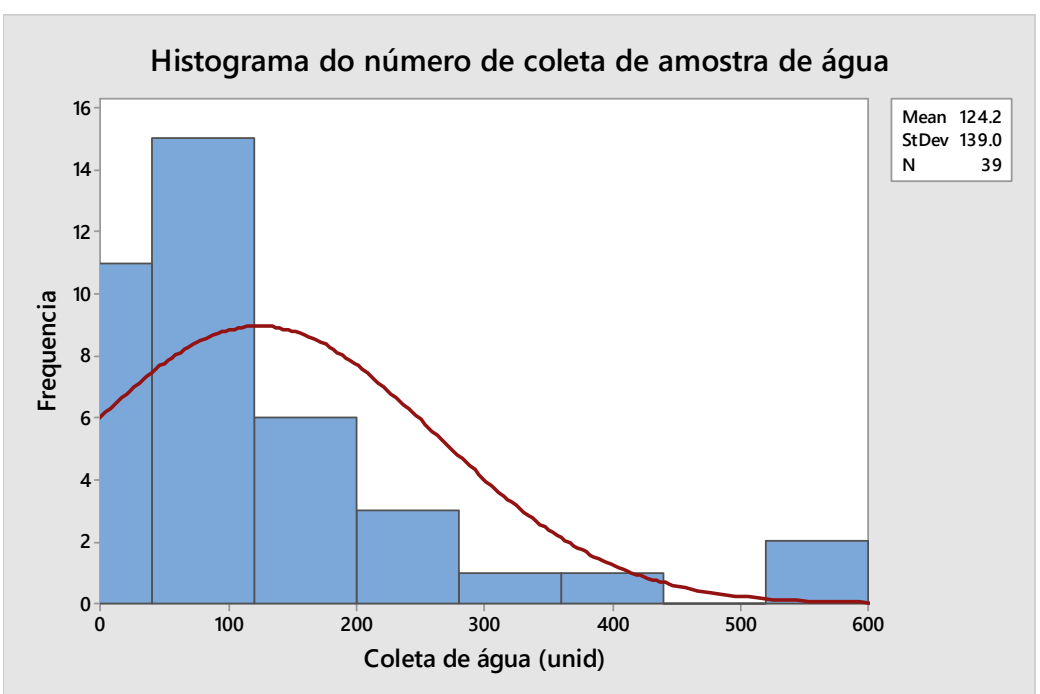

Gráfico 5.23 - Histograma do número de coleta de amostra de água por área investigada.

\section{ANÁLISE ESTATIISTICA}

Número de coleta de amostra de água por área investigada (unidade)

Média $=$ 124,2

Erro padrão $=22,3$

Desvio padrão = 139,0

Mediana $=$ 17,0

$\mathrm{N}^{0}$ amostras $=$ 39

Pode-se concluir que, de todas as análises químicas efetuadas nas amostras coletadas nas áreas contaminadas avaliadas, o principal grupo analítico é do Benzeno, Tolueno, Etilbenzeno e Xilenos (BTEX), efetuadas em $100 \%$ das amostras coletadas, com 5.734 (cinco mil, setecentos e trinta e quatro) análises efetuadas. 
A análise do grupo dos Hidrocarbonetos Poliaromáticos (PAH) foi efetuada 5.546 (cinco mil, quinhentos e quarenta e seis) vezes ao longo de todas as áreas (em número 3,5\% menor que o BTEX), é o segundo maior grupo analítico analisado. Foram efetuadas, em média, 147 (cento e quarenta e sete) análises de BTEX e 143 (cento e quarenta e três) de PAH, conforme apresentado nos Gráficos 5.24 e 5.25 respectivamente.

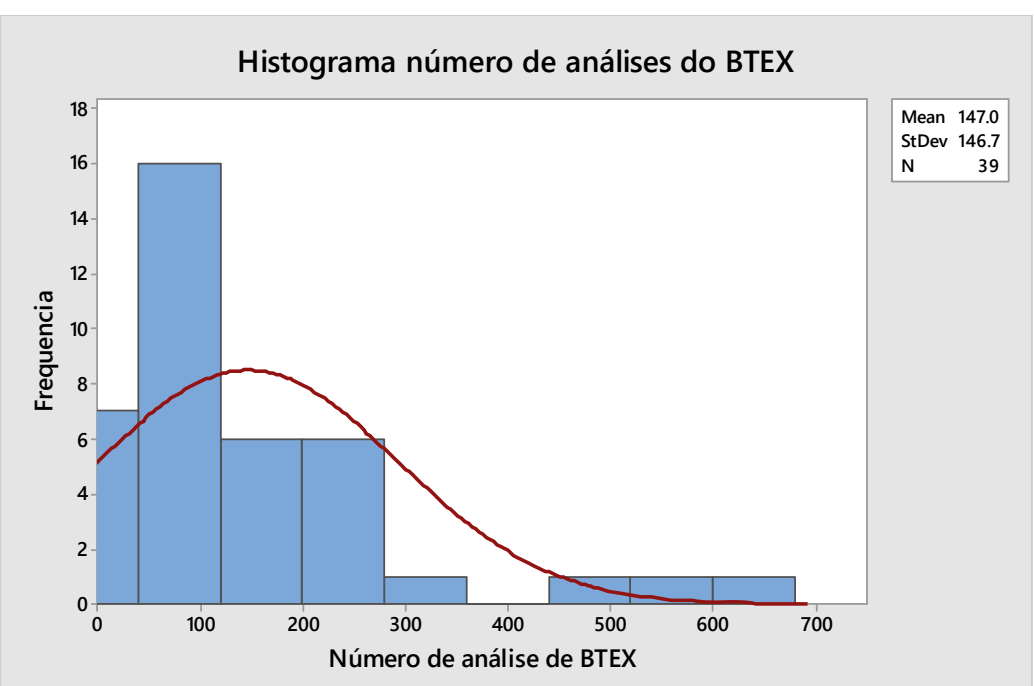

Gráfico 5.24 - Histogramado número de análises químicas do parâmetro Benzeno, Tolueno, Etilbenzeno e Xilenos (BTEX).

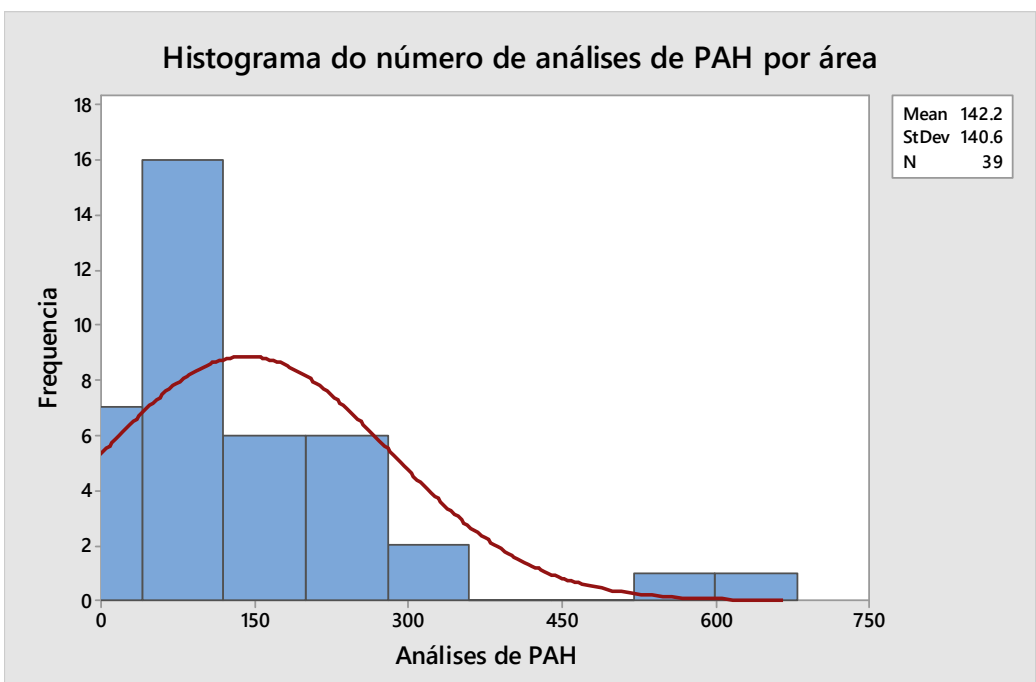

Gráfico 5.25 - Histogramado número de análises químicas do parâmetro Hidrocarboneto Poliaromático (PAH).

\section{ANÁLISE ESTATÍSTICA}

Número de análises deBTEX por área investigada.

(unidade)

Média $=$ 147,0

Erro padrão $=23,5$

Desvio padrão $=146,7$

Mediana $=95,0$

$\mathrm{N}^{\circ}$ amostras $=$ 39

\section{ANÁLISE ESTATÍSTICA}

Número de análises dePAH por área investigada. (unidade)

Média $=$ 142,2

Erro padrão $=22,5$

Desvio padrão $=\quad 140,6$

Mediana $=80,0$

$\mathrm{N}^{\circ}$ amostras $=$ 39 
As áreas avaliadas indicam, também, a execução de 693 (seiscentos e noventa e três) análises de Hidrocarboneto Total de Petróleo (TPH), 652 (seiscentos e cinquenta e duas) análises de etanol e 231 (duzentos e trinte e uma) análises de Hidrocarboneto Total de Petróleo pelo método fingerprint $\left(\mathrm{TPH}_{f}\right)$, com as seguintes médias respectivas: 77 (setenta e sete) de TPH, 60 (sessenta) de etanol, 39 (trinta e nove) de $\mathrm{TPH}_{f}$

\subsubsection{Das características da ocorrência do contaminante}

De forma a avaliar a ocorrência tridimensional dos contaminantes em suas diversas fases (retida, vapor, livre e dissolvida), o comprimento e a largura de suas áreas de ocorrência foram parametrizados, assim como sua espessura, e inseridos no banco de dados para análise. A Tabela 5.5 consolida as médias aritméticas dos dados parametrizados. Apesar de em alguns relatórios constar a área total de ocorrência do contaminante em suas diversas fases, nenhum documento apresentava suas dimensões. Assim, estas informações foram obtidas diretamente dos mapas e perfis constantes nos mesmos.

Foi verificado, nesta pesquisa, uma variação da área de ocorrência do contaminante no local, em suas diversas fases mapeadas, em função:

a) Do avanço da investigação ambiental da área - Verificou-se a existência de mapas de áreas de ocorrência sem que as mesmas tenham sido totalmente delimitadas, e, assim, usualmente menores que os mapas gerados posteriormente, com a ocorrência do contaminante totalmente delimitado.

b) Aumento dos pontos de investigação - O maior número de pontos de investigação possibilita um maior detalhamento da ocorrência dos contaminantes presentes, alterando o mapa final delimitado.

c) Procedimento de desenho da ocorrência do contaminante - Observou-se que a variação da área do contaminante alterava em função do procedimento de desenho adotado, onde a geometria da mesma é definida sem critérios claros, conforme demonstra a Figura 5.4. 
Tabela 5.5 - Quantitativos médios da ocorrência da fase vapor nas áreas analisadas.

\begin{tabular}{|c|c|c|c|c|c|c|c|c|c|c|c|c|}
\hline \multirow{2}{*}{ 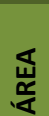 } & \multirow{2}{*}{$\begin{array}{c}\text { DADOS } \\
\text { Poço } \\
\text { água }\end{array}$} & \multirow{2}{*}{$\begin{array}{l}\text { Área } \\
\text { Fonte } \\
\text { (m2) }\end{array}$} & \multirow{2}{*}{$\begin{array}{l}\text { ZN Sat } \\
(\mathrm{m})\end{array}$} & \multicolumn{3}{|c|}{$\begin{array}{l}\text { ANÁLISE DE OCORRÊNCIA } \\
\text { FASE VAPOR }(\mathrm{m})\end{array}$} & \multicolumn{3}{|c|}{$\begin{array}{l}\text { ANÁLISE DE OCORRÊNCIA } \\
\text { FASE LIVRE }(\mathrm{m})\end{array}$} & \multicolumn{3}{|c|}{$\begin{array}{l}\text { ANÁLISE DE OCORRÊNCIA } \\
\text { FASE DISSOLVIDA (m) }\end{array}$} \\
\hline & & & & Esp & Larg & Comp & Esp & Larg & Comp & Esp & Larg & Comp \\
\hline 1 & Não & 125.0 & 2.8 & & & & & & & & & \\
\hline 2 & Não & 190.0 & 7.5 & & & & & & & & & \\
\hline 3 & Sim & 620.0 & 7.5 & & & & & & & & & \\
\hline 4 & Não & 500.0 & 6.1 & 6.0 & 30.0 & 40.0 & & & & 10.0 & 65.0 & 105.0 \\
\hline 5 & Não & 625.0 & 2.0 & & & & 0.020 & 2.0 & 2.0 & 3.0 & 30.0 & 20.0 \\
\hline 6 & Não & 225.0 & 7.0 & & & & 0.030 & 25.0 & 30.0 & 2.0 & 41.0 & 20.0 \\
\hline 7 & Não & 625.0 & 10.0 & & & & 0.240 & 3.0 & 4.0 & 2.5 & 35.0 & 60.0 \\
\hline 8 & Não & 360.0 & 9.0 & & & & & & & 2.0 & 45.0 & 50.0 \\
\hline 9 & Não & 1100.0 & 1.1 & & & & 0.020 & 1.0 & 2.0 & 2.2 & 65.0 & 23.0 \\
\hline 10 & Não & 4800.0 & 1.0 & & & & 0.970 & 2.0 & 5.0 & 1.0 & 87.0 & 32.0 \\
\hline 11 & Não & 700.0 & 10.0 & & & & 0.030 & 25.0 & 30.0 & 2.0 & 30.0 & 42.0 \\
\hline 12 & Não & 884.0 & 4.0 & & & & & & & 2.0 & 50.0 & 41.0 \\
\hline 13 & Não & 468.0 & 1.8 & & & & 0.003 & 25.0 & 15.0 & 2.0 & 50.0 & 40.0 \\
\hline 14 & Não & 160.0 & 4.0 & 1.0 & 15.0 & 10.0 & & & & 2.0 & 22.0 & 29.0 \\
\hline 15 & Não & 240.0 & 1.0 & & & & & & & & & \\
\hline 16 & Não & 690.0 & 6.5 & & & & & & & 2.0 & 20.0 & 16.0 \\
\hline 17 & Não & 352.0 & 1.3 & & & & & & & & & \\
\hline 18 & Não & 505.0 & 1.3 & 1.0 & 7.9 & 15.3 & 0.300 & 4.0 & 6.0 & 1.0 & 2.0 & 3.0 \\
\hline 19 & Não & 1089.0 & 5.0 & & & & & & & & & \\
\hline 20 & Não & 390.0 & 4.0 & & & & & & & & & \\
\hline 21 & Não & 146.3 & 3.0 & & & & & & & & & \\
\hline 22 & Não & 340.0 & 6.3 & & & & & & & 2.1 & 15.0 & 20.0 \\
\hline 23 & Não & 396.0 & 1.2 & & & & 0.050 & 1.0 & 1.0 & 2.0 & 28.0 & 37.0 \\
\hline 24 & Não & 120.0 & 2.7 & & & & & & & 2.0 & 18.0 & 25.0 \\
\hline 25 & Não & 360.0 & 8.2 & & & & 0.020 & 4.0 & 8.0 & 2.2 & 72.0 & 115.0 \\
\hline 26 & Não & 1350.0 & 6.5 & 6.0 & 4.4 & 8.0 & & & & 2.7 & 15.0 & 40.0 \\
\hline 27 & Não & 396.0 & 11.0 & & & & 0.050 & 1.0 & 1.0 & 2.0 & 16.0 & 8.0 \\
\hline 28 & Não & 105.0 & 5.0 & & & & 0.200 & 1.0 & 2.0 & 2.0 & 15.0 & 25.0 \\
\hline 29 & Sim & 475.0 & 7.5 & & & & 0.001 & 1.0 & 1.0 & 4.0 & 27.0 & 83.0 \\
\hline 30 & Não & 600.0 & 7.5 & & & & & & & & & \\
\hline 31 & Não & 175.0 & 8.2 & & & & 0.900 & 44.0 & 66.0 & 2.0 & 35.0 & 80.0 \\
\hline 32 & Não & 405.0 & 0.9 & & & & 0.100 & 4.5 & 4.5 & 2.0 & 8.0 & 15.0 \\
\hline 33 & Sim & 234.0 & 1.6 & & & & 0.020 & 16.0 & 30.0 & 1.8 & 21.0 & 33.0 \\
\hline 34 & Sim & 117.0 & & & & & 0.050 & 5.0 & 6.0 & 1.0 & 14.0 & 32.0 \\
\hline 35 & Não & 370.0 & 2.5 & 2.0 & 28.0 & 35.0 & 0.900 & 21.0 & 27.0 & & & \\
\hline 36 & Sim & 3240.0 & 1.9 & & & & 0.200 & 31.0 & 38.5 & 2.1 & 76.0 & 95.0 \\
\hline 37 & Não & 150.0 & 4.3 & & & & & & & 2.0 & 10.0 & 17.0 \\
\hline 38 & Sim & 121.0 & & 7.5 & 12.5 & 22.5 & 0.030 & 2.0 & 2.0 & & & \\
\hline 39 & Não & 209.0 & 1.0 & 1.0 & 10.2 & 14.7 & & & & 3.0 & 13.0 & 24.0 \\
\hline 40 & Não & 100.0 & 6.0 & 5.5 & 12.5 & 22.3 & & & & & & \\
\hline 41 & Sim & 225.0 & 2.0 & & & & & & & & & \\
\hline 42 & Sim & 450.0 & 3.4 & & & & & & & 2.0 & 18.0 & 23.0 \\
\hline 43 & Sim & 622.0 & 2.3 & & & & 2.140 & 27.0 & 30.0 & 2.0 & 38.0 & 15.0 \\
\hline 44 & Não & 115.0 & 6.5 & & & & 0.080 & 34.0 & 10.0 & 2.0 & 52.0 & 26.0 \\
\hline
\end{tabular}

ZN Sat - Profundidade do nível de água; Esp - Espessura da ocorrência do contaminante definido em seção; Larg - Largura da ocorrência do contaminante definido em planta; Comp - Comprimento da ocorrência do contaminante definido em mapa.

Este mesmo problema de variação da delimitação da ocorrência do contaminante em área também foi verificado na delimitação do contaminante em profundidade, nas seções geológicas constantes nos relatórios.

Cabe destacar, ainda, que os documentos avaliados, 0 mapeamento dos contaminantes apenas visava a delimitação de sua ocorrência em concentração acima do padrão legal ou das Concentrações Máximas Aceitáveis (CMA) estabelecidas com base no risco, e não sua ocorrência no subsolo. 


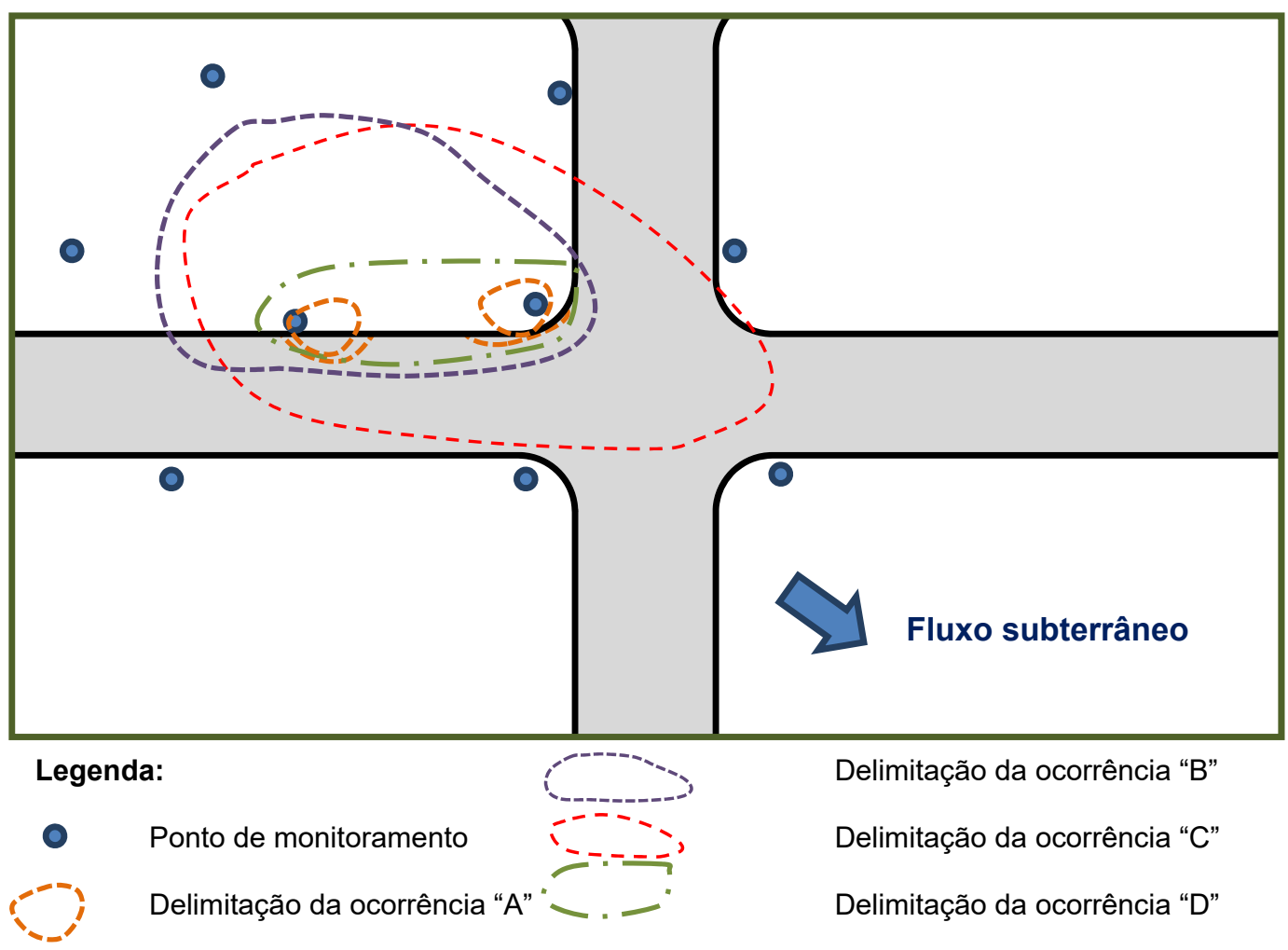

Figura 5.4 - llustração do autor da variação da área de ocorrência do contaminante em função do procedimento de delimitação e desenho da mesma.

De forma a não considerar possíveis variações de geometria da ocorrência das diversas fases de combustível no subsolo em função da interferência de processos de remediação ou da existência de bombeamentos de poços próximos, os dados de geometria foram analisados tendo por premissa:

$\checkmark$ A ocorrência ou não de poços de captação de água na área.

$\checkmark$ Utilização dos registros obtidos antes do início de processos de remediação na área.

$\checkmark$ Uso dos maiores valores identificados e, consequentemente, a maior área de ocorrência mapeada, usualmente obtida antes das ações de remediação. 


\subsubsection{Características da ocorrência da fase retida}

Os resultados das investigações desenvolvidas nas áreas avaliadas indicam que a fase retida na zona não saturada apenas ocorre de forma restrita, próxima da área fonte da contaminação. Não foi observada, nos documentos analisados, a ocorrência de fase retida anômala situada a distâncias superiores a 2,0 m em relação à área fonte, condizente com uma infiltração vertical proveniente de vazamentos do sistema de abastecimento. Foram observados, no entanto, casos de ocorrência de solo contaminado próximos à zona de capilaridade, a distância maiores que 2,0 m, associados à variações verticais de fase livre do contaminante, devido à variação sazonal do nível de água.

Os registros da ocorrência da fase retida próximos à fonte de contaminação indicam a não ocorrência de escoamento superficial do produto com posterior infiltração, distante da fonte.

O volume de solo contaminado será, no máximo, o volume definido pela área da fonte de contaminação (delimitada) pela profundidade do nível de água, ou espessura da zona não saturada.

\subsubsection{Características da ocorrência da fase vapor}

A fase vapor mapeada é representativa da volatilização do produto da fase retida, livre e dissolvida presente na área e, assim, sua ocorrência varia em função da associação de todas as fases do contaminante no subsolo.

Verificou-se que o mapeamento da fase vapor no terreno, usualmente, ocorre apenas no início das etapas de Gerenciamento de Área Contaminada (GAC), com a execução do Soil Gas Survey (SGS) ou associado aos pontos de sondagem de investigação da fase retida ou dissolvida presentes no subsolo, sendo, este último, o principal ponto de medição e o único ponto de monitoramento existente nas áreas avaliadas.

Apenas 8 (oito) das áreas analisadas apresentavam uma delimitação da fase vapor, todas efetuadas após o início das atividades de remediação. Uma destas áreas apresenta poço de captação da água subterrânea e, assim, sua área total pode ter sofrido variação em função da influência dos bombeamentos, com a dispersão da fase dissolvida e livre. 
Apesar do número baixo de áreas com a fase vapor mapeadas, foi possível obter uma boa correlação entre a largura de sua ocorrência e a largura da fase dissolvida (Gráfico 5.26), mas não entre os comprimentos. A correlação obtida se deve ao fato de que o mapeamento da fase vapor, quando ocorre, apenas se restringe à área interna do empreendimento, e as larguras das fontes de vapor provenientes das fases retida, livre e dissolvida são condicionadas pela geometria da área fonte em relação à direção do fluxo subterrâneo (Figura 5.5), uma vez que todas as fases tem origem na área fonte, situada dentro do empreendimento. Já o comprimento das fases livre e dissolvida podem ultrapassar os limites da área do empreendimento e, consequentemente, dos mapeamentos da fase vapor.

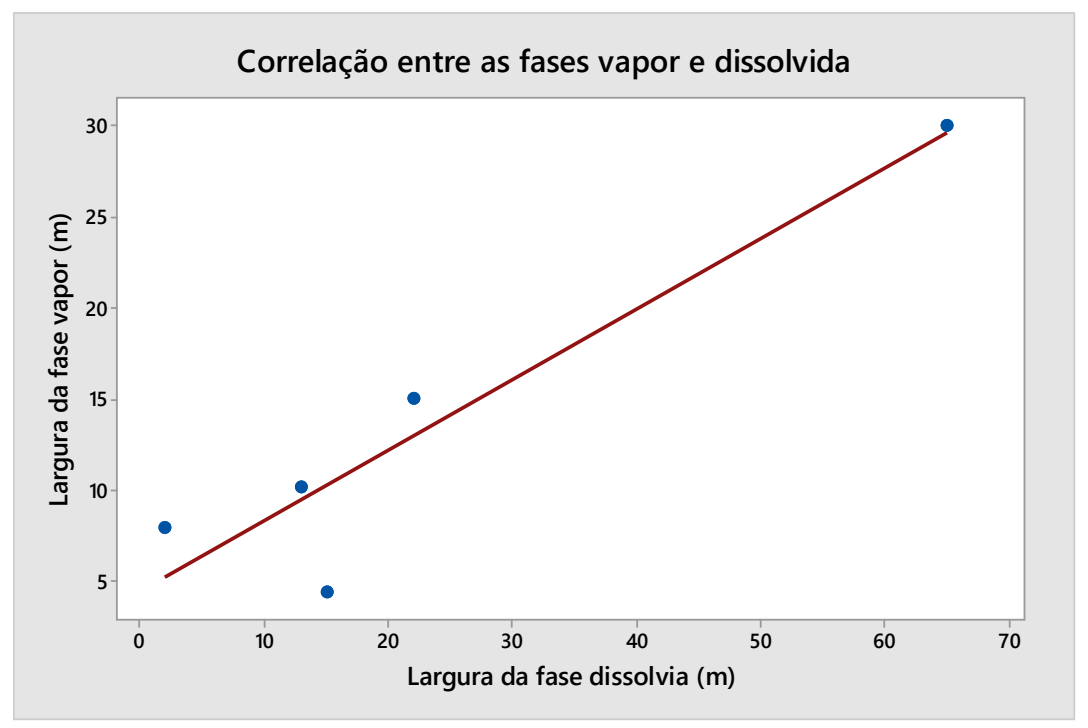

Gráfico 5.26 - Correlação entre as larguras da ocorrência das fases vapor e dissolvida.

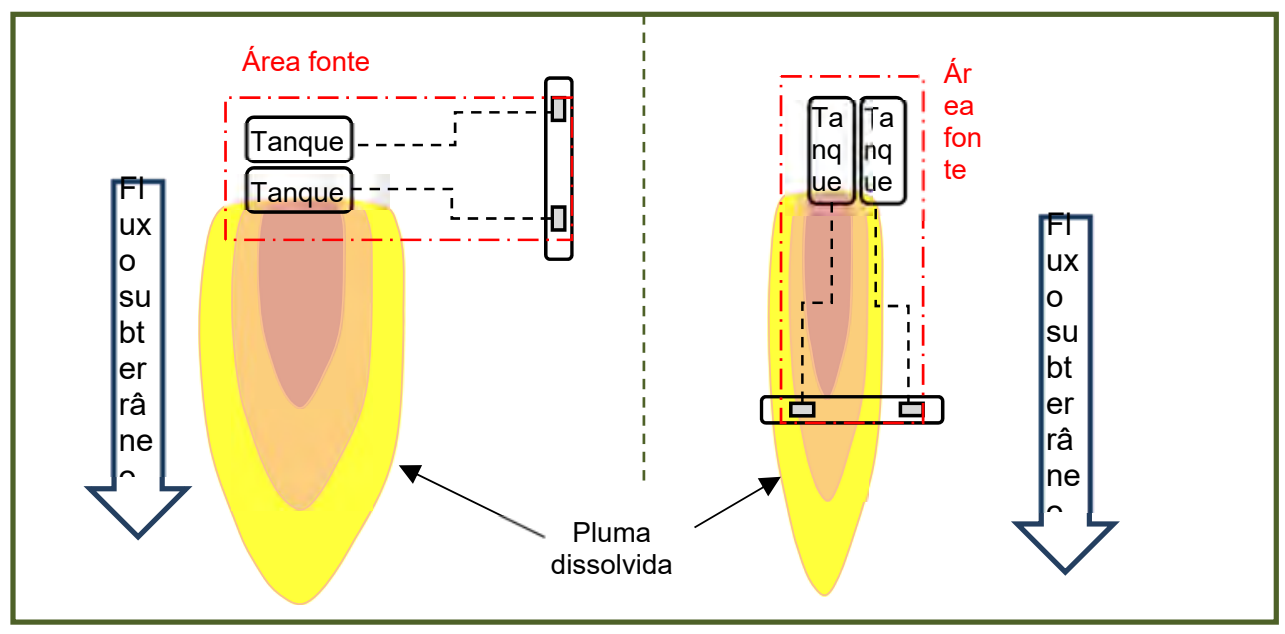

Figura 5.5 - Variação da largura da fase dissolvida em função da geometria da fonte e o vetor do fluxo principal da água subterrânea. 
5.4.3.3 Características da ocorrência da fase livre

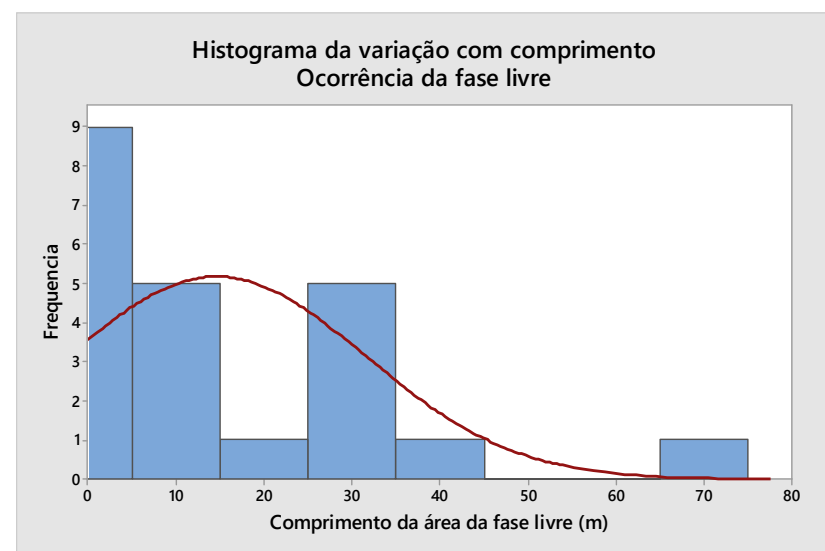

Análise do comprimento da ocorrência da fase livre $(m)$

$\begin{array}{cc}\text { Média }= & 14,6 \\ \text { Erro padrão }= & 3,61 \\ \text { Desvio padrão }= & 16,94 \\ \text { Mediana }= & 6,0 \\ \text { N }^{\circ} \text { amostras }= & 22\end{array}$

Gráfico 5.27 - Histograma do comprimento médio da fase livre de combustíveis no subsolo, por área analisada nessa tese.
Os registros da ocorrência da fase livre, mapeado em 22 (vinte e duas) das 44 (quarenta e quatro) áreas, indicam que as mesmas ocorrem, essencialmente, dentro da área do empreendimento. Apresentam medidas médias de $14,6 \mathrm{~m}$ de comprimento por $12,2 \mathrm{~m}$ de largura, conforme apresentado nos Gráficos $\mathbf{5 . 2 7}$ e 5.28 .

Os dados da espessura aparente da fase livre medida nos poços de monitoramento indicam um ocorrência média de $0,29 \mathrm{~m}$ (Gráfico 5.29).

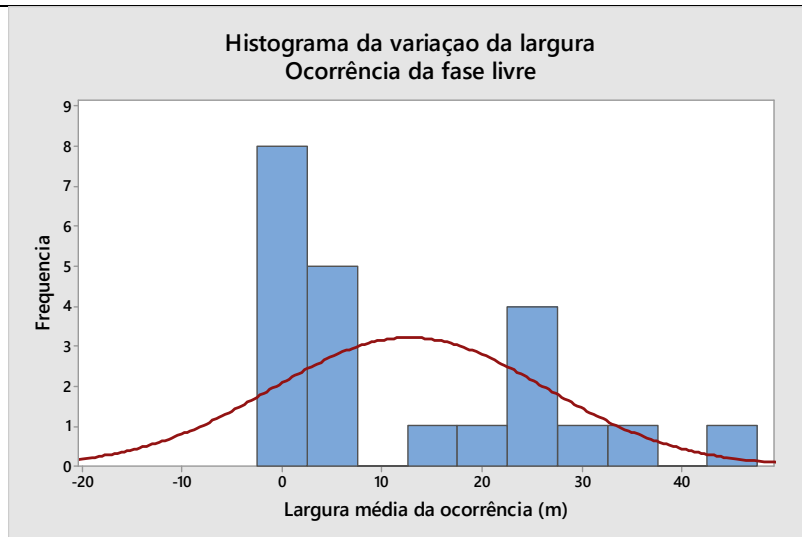

Análise da largura da ocorrência da fase livre $(m)$

$\begin{array}{cc}\text { Média }= & 12,2 \\ \text { Erro padrão }= & 2,91 \\ \text { Desvio padrão }= & 13,64 \\ \text { Mediana }= & 80,0 \\ \text { No }^{\circ} \text { amostras }= & 22\end{array}$

Gráfico 5.28 - Histograma da largura média da fase livre de combustíveis no subsolo, por área analisada nessa tese.

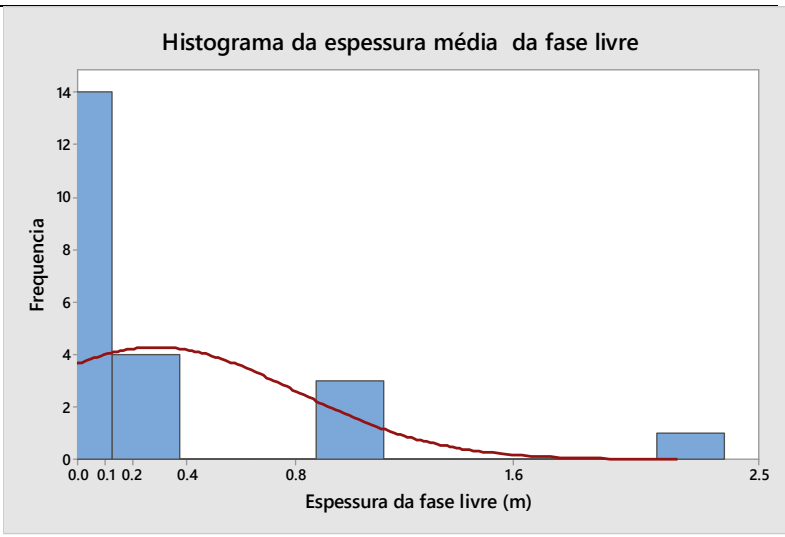

Análise da espessura aparente de ocorrência da fase livre $(m)$

$$
\begin{array}{cc}
\text { Média }= & 0,29 \\
\text { Erro padrão }= & 0,11 \\
\text { Desvio padrão }= & 0,52 \\
\text { Mediana }= & 0,05 \\
\text { No }^{0} \text { amostras }= & 22
\end{array}
$$

Gráfico 5.29 - Histograma da espessura média aparente de fase livre de combustíveis no subsolo, por área analisada nessa tese. 
5.4.3.4 Características da ocorrência da fase dissolvida

Para as áreas analisadas, verificou-se que nenhuma das plumas mapeadas apresentou comprimento maior que $150 \mathrm{~m}$ em relação à fonte de contaminação, independente da presença de poços de abastecimento próximos ou do etanol em sua composição. Assim, confirma-se a tendência citada por Oliveira (2016) de que os compostos contaminantes da gasolina sofrem atenuação natural e, usualmente, não originam plumas de fase dissolvida maiores que 150 a 200 m, a partir da fonte.

A análise das informações efetuada pelo autor indica, ainda, que o principal fator da largura da pluma contaminante é a geometria da fonte de contaminação em relação à direção preferencial de fluxo, que existe a tendência de plumas mais largas (algumas vezes com largura maior que o comprimento) em áreas quando o maior comprimento do polígono de delimitação da fonte de contaminação situa-se de forma perpendicular aos fluxos subterrâneos, conforme ilustra a Figura 5.5.

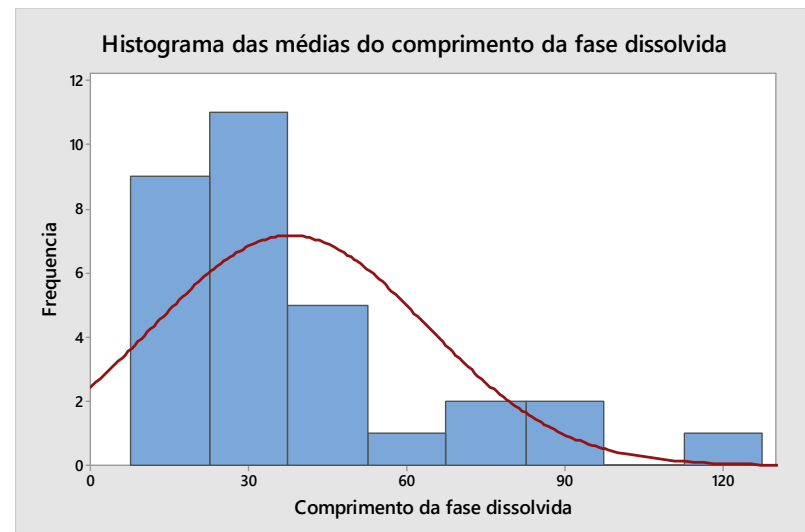

Análise do comprimento da ocorrência da fase dissolvida $(\mathrm{m})$

$\begin{array}{cc}\text { Média }= & 37,9 \\ \text { Erro padrão }= & 4,65 \\ \text { Desvio padrão }= & 25,91 \\ \text { Mediana }= & 29,0 \\ \mathrm{~N}^{\circ} \text { amostras }= & 31\end{array}$

Gráfico 5.30 - Histograma do comprimento médio da fase dissolvida de combustíveis no subsolo, por área analisada nessa tese.
A fase dissolvida apresentou um comprimento médio de $37,9 \mathrm{~m}$, com máxima distância de $115 \mathrm{~m}$, e largura média de 33,6 m (máximo de 87,0 m), conforme análises estatísticas apresentadas nos Gráficos 5.30 e 5.31, respectivamente.

Em contraponto a espessura da fase dissolvida apresentou uma média de 2,1 m, podendo atingir até 4,0 m (Gráfico 5.32).

As maiores áreas de ocorrência da fase dissolvida foram observadas nas áreas que não apresentavam poços de água cadastrados no empreendimento, indicando uma não influência dos mesmos. 


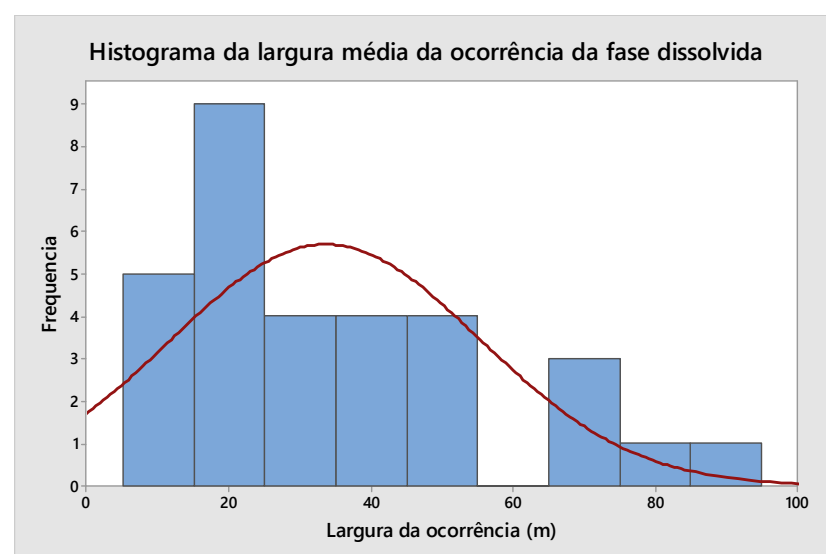

Análise da largura da ocorrência da fase dissolvida $(\mathrm{m})$

$\begin{array}{cc}\text { Média }= & 33,6 \\ \text { Erro padrão }= & 3,90 \\ \text { Desvio padrão }= & 21,73 \\ \text { Mediana }= & 28,0 \\ \text { N }^{\circ} \text { amostras }= & 31\end{array}$

Gráfico 5.31 - Histograma da largura média da fase dissolvida de combustíveis no subsolo, por área analisada nessa tese.

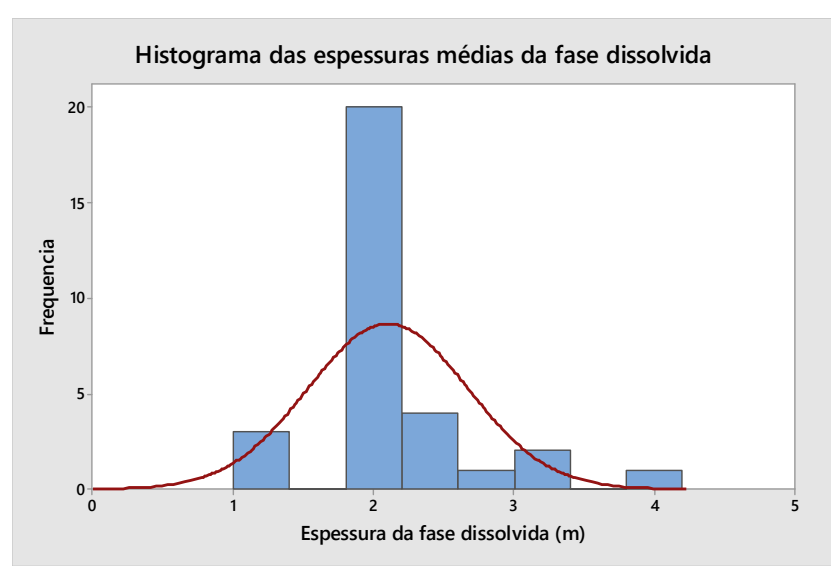

Análise da espessura da ocorrência da fase dissolvida $(\mathrm{m})$

$\begin{array}{cc}\text { Média }= & 2,1 \\ \text { Erro padrão }= & 0,10 \\ \text { Desvio padrão }= & 0,57 \\ \text { Mediana }= & 2,0 \\ \mathrm{~N}^{\circ} \text { amostras }= & 31\end{array}$

Gráfico 5.32 - Histograma da espessura média da fase dissolvida de combustíveis no subsolo, por área analisada nessa tese.

\subsection{ANÁLISE DOS PRAZOS ENVOLVIDOS NA REPARAÇÃO DO DANO REVERSÍVEL}

Para a análise dos prazos do dano reversível, foram avaliadas as datas de execução das etapas de remediação constantes nos relatórios ambientais (que foram parametrizados), considerando as datas de emissão dos documentos. A Tabela 5.6 resume os prazos (em meses) a partir do início da operação de cada técnica envolvida em relação à etapa anterior, referentes as áreas avaliadas nessa tese.

Os dados analisados sugerem que a remediação do dano reversível, com a aplicação de uma ou mais técnicas, com ou sem a remoção da fonte, ocorre em um prazo total médio de 44 (quarenta e quatro) meses, ou 3,7 (três vírgula sete) anos, variando de 4 (quatro) a 152 (cento e cinquenta e dois) meses, ou 0,3 (zero vírgula três) a 12,7 (doze vírgula sete) anos (Gráfico 5.33).

Este alto desvio padrão, representativo da complexidade do tema e a necessidade de análise dos prazos em função das características e objetivos das ações, não podendo ser analisada em um único grupo. 
Tabela 5.6 - Prazos envolvidos no Gerenciamento de Área Contaminada (em meses) a partir do relatório da etapa anterior.

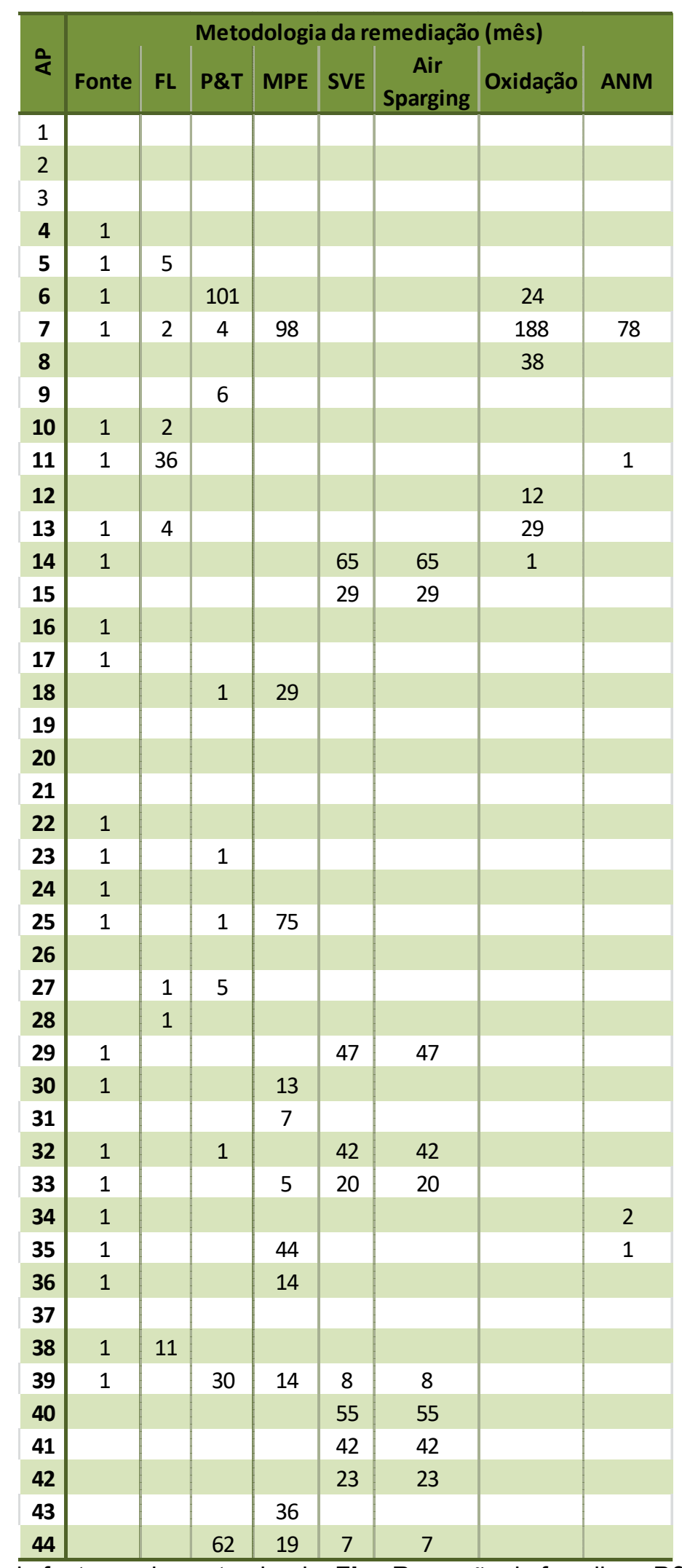

Fonte - Remoção de fonte e solo contaminado; FL - Remoção de fase livre; P\&T - Pump \&Treat; MPE - Remediação multifásica; SVE - Extração de vapores; ANM - Atenuação natural monitorada. 
$\mathrm{Na}$ avaliação do tempo total de remediação, não foram considerados os casos em que ocorreu apenas a remoção da fonte (solo e tanque de armazenamento de combustível subterrâneo - SACS), sem qualquer outra técnica aplicada em paralelo. Esta situação, verificada em 10 (dez) da áreas, apresenta um prazo menor que 1 (um) mês para todas as áreas.

Muitas das remediações não ocorrem de maneira contínua, assim como é comum ocorrer a troca de metodologias e a aplicação de técnicas simultâneas.

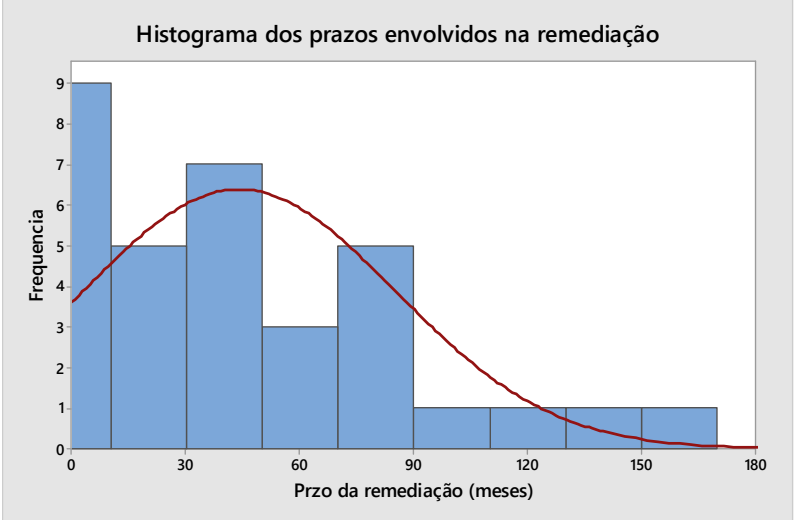

Análise dos prazos (mês) de remediação (REM), sem considerar a remoção da fonte

$\begin{array}{lc}\text { Média }= & 43,9 \\ \text { Erro padrão }= & 7,18 \\ \text { Desvio padrão }= & 41,25 \\ \text { Mediana }= & 37,0 \\ \text { N }^{0} \text { amostras }= & 33\end{array}$

Gráfico 5.33 - Histograma dos prazos de remediação (REM) sem considerar a remoção da fonte.

Assim, na representatividade do prazo total de remediação, foi considerado o período entre o início da primeira atividade de remediação e a última, constatada na documentação avaliada.

A análise do número de técnicas de remediação aplicadas, a remoção da fonte (tanques de combustíveis e solo contaminado) é a mais utilizada, ocorrendo em 23 (vinte e três) das 40 (quarenta) áreas que efetuaram ações de remediação, ou 57,5 \% das vezes (Gráfico 5.34). Entretanto, em 4 (quatro) dos casos cadastrados, a remoção do tanque foi efetuada sem que tenha sido identificada, previamente, a contaminação do terreno, com a remoção desenvolvida em conjunto com uma das etapas de investigação do gerenciamento de áreas contaminadas. Assim, estes casos foram considerados como simples troca de equipamento (tanques de combustível).

Dos casos de remoção da fonte e do solo contaminado, apenas 2 (dois), ou 10,52\% deles, não obtiveram o encerramento do Gerenciamento de Área Contaminada (GAC), sugerindo ser este, um fator chave no processo de recuperação do dano ambiental 
Observou-se, ainda, que todos os casos de aplicação da Extração do Vapor do Solo (SVE) ocorreram em conjunto com a tecnologia de injeção de ar, ou Air Sparging (ASp), e, assim, as tecnologias foram consideradas como uma única técnica aplicada.

Desconsiderando a remoção da fonte de contaminação em

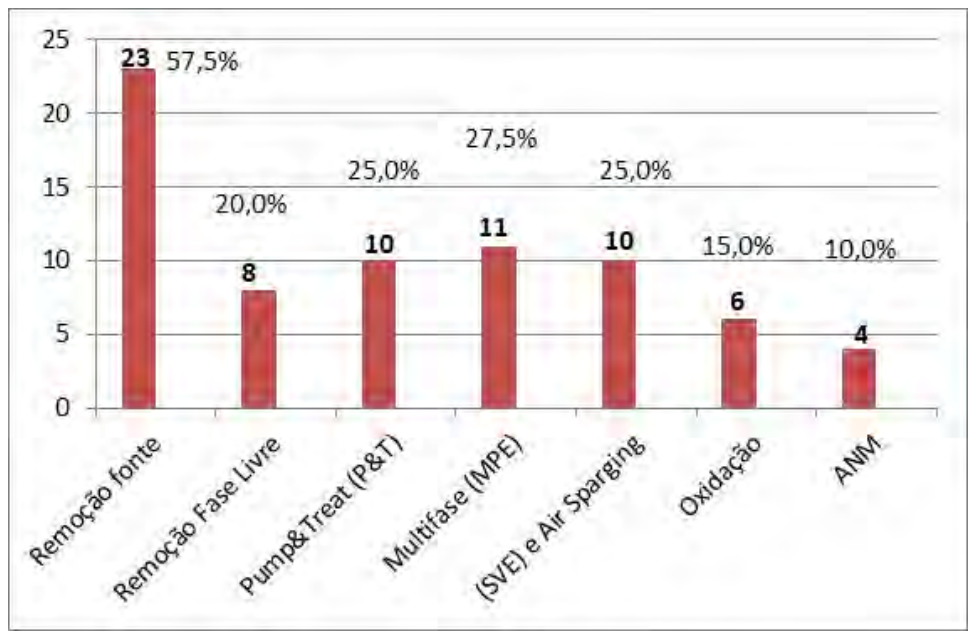

Gráfico 5.34 - Ocorrência das tecnologias de remediação aplicadas. conjunto com o solo contaminado, as tecnologias de maior incidência são a da Extração Multifásica (MPE), seguida do Pump \& Treat (P\&T) e da Extração de Vapores (SVE) com ventilação induzida - Air Sparging (ASp). Estas tecnologias podem ser aplicadas para a remediação das fases de combustíveis fósseis presentes no subsolo e contemplam as principais técnicas de remediação do dano reversível.

Podem ser aplicadas mais de uma metodologia de remediação do dano reversível. Estas, foram agrupadas, pelo autor, em função de sua eficácia na diminuição da massa contaminante em suas diversas fases (vapor, adsorvido, livre e dissolvido), em:

$\checkmark$ Remoção da fonte (para interromper a continuidade da contaminação) e do solo contaminado (para a remediação da fase retida).

$\checkmark$ Remoção da fase livre e, secundariamente, fase dissolvida, sem ênfase na fase vapor, representada pela técnica do P\&T e, secundariamente, demais técnicas de remoção do produto livre no subsolo.

$\checkmark$ MPE para a remediação da fase livre e vapor associados, secundariamente atuando na fase dissolvida.

$\checkmark$ SVE com ASp para a remediação da fase dissolvida e, secundariamente, da fase vapor. 
Outras técnicas de remediação são possíveis de serem utilizadas. Entretanto, estas, quando utilizadas em substituição às citadas acima, devem proporcionar menores prazos de remediação e/ou custos associados. Assim, a sequência de ações de remediação proposta nesta tese apresenta caráter conservador, com prazos médios que podem ser minimizados com a evolução do conhecimento da área ao longo do desenvolvimento das etapas de Gerenciamento de Área Contaminada (GAC).

\subsubsection{Prazos para a reparação da fonte da contaminação e da fase retida}

A eliminação da fonte de contaminação de combustível possibilita a eliminação da continuidade do processo de contaminação do ambiente, e, a escavação para a remoção do sistema de armazenamento, permite a remoção do solo contaminado com a maior concentração retida (hot spot) dos contaminantes, usualmente localizada próxima da fonte - tanque ou linha de combustível.

A fase retida é uma fonte contínua de geração da fase vapor, e sua lixiviação, incrementa a fase dissolvida. Assim, sua remoção é fator chave da remediação destas outras fases de combustível no subsolo.

A diminuição da massa contaminante presente em fase retida no solo também pode ser promovida(e usualmente é) pelas técnicas de Extração Multifásica (MPE) e de Vapores (SVE), em conjunto ou não com a injeção de ar (Air Sparging - ASp). Assim, a remoção do solo contaminado durante a remoção da fonte de contaminação deve ser entendida como o início (e principal) processo de eliminação do dano ambiental reversível do solo.

Dos 23 (vinte e três) casos em que ocorreu a remoção da fonte de contaminação e do solo contaminado, apenas em 2 (dois) dos casos, não foi obtido o encerramento do Gerenciamento de Área Contaminada (GAC) após as ações de remediação, o que sugere forte influência dessa ação na eficácia do processo. Infelizmente, a identificação de vazamento é uma exceção, sendo efetuada em 13 (treze) dos 44 (quarenta e quatro) casos analisados (29,5\% do total), e, apenas ocorrendo o registro da perda de combustível, sem identificar o local (se no tanque, linha ou bombas). Assim, a remoção do sistema de armazenamento e distribuição de combustíveis deveria ocorrer quando se verifica a presença de combustível no subsolo. 
A remoção da fonte de contaminação (tanque e linha de abastecimento) e do solo contaminado (área principal - hot spot) foi executada em um período inferior a um mês em $100 \%$ das vezes, conforme indicado em capítulo anterior.

Não foi possível obter, entretanto, qualquer correlação numérica de possível influência da remoção da fonte de contaminação e solo contaminado no tempo total da remediação, assim como da desativação do local com a consequente facilidade de operação das ações de remediação (sem estruturas superficiais ou enterradas ou atividades no local).

\subsubsection{Prazos para a reparação da fase livre}

Quando se avalia a aplicação da metodologia de remoção da fase livre de combustível, o Pump \& Treat (P\&T) é a principal tecnologia aplicada, usada em 10 (dez) dos 16 (dezesseis) casos verificados. Os registros indicam que:

a) Após um período inicial, a metodologia do P\&T é substituída pela extração multifásica (MPE), com o objetivo de efetuar o controle e a diminuição da fase vapor e dissolvida, ocorrendo em $50 \%$ das vezes (5 - cinco -dos casos).

b) Em $50 \%$ dos casos avaliados por qualquer uma das técnicas de remoção da fase livre, após a eliminação da mesma, houve a necessidade de introdução de outra metodologia para o tratamento da fase vapor ou dissolvida.

Para os casos em que ocorreu a remoção da fase livre pela tecnologia do P\&T sem a necessidade de complemento de outra tecnologia para o tratamento da fase vapor ou dissolvida, o tempo médio de aplicação foi de 22 (vinte e dois) meses. No entanto, a remoção da fase livre por outras técnicas, em média, foi aplicada por 8 (oito) meses.

Para uma melhor análise do tempo necessário na remoção da fase livre, todos os casos de remediação de fase livre foram agrupados, independente da técnica aplicada, representando um conjunto de 16 (dezesseis) áreas diferentes. Nesta situação, observou-se um prazo médio de 17 (dezessete) meses (Gráfico 5.35) de aplicação das técnicas de remoção da fase livre, seja utilizando bailer, skimmers passivos e ativos ou pela técnica do P\&T. 
A alta variabilidade do prazo reflete os casos em que a técnica foi iniciada e, posteriormente, substituída por outras de melhor eficiência, assim como, casos em que houve a insistência da aplicação da técnica mesmo com pouca eficácia, permanecendo por longo períodos (possivelmente devido à cláusulas contratuais, limitações financeiras de desembolso, preferência da consultoria ou do contratante, etc.).

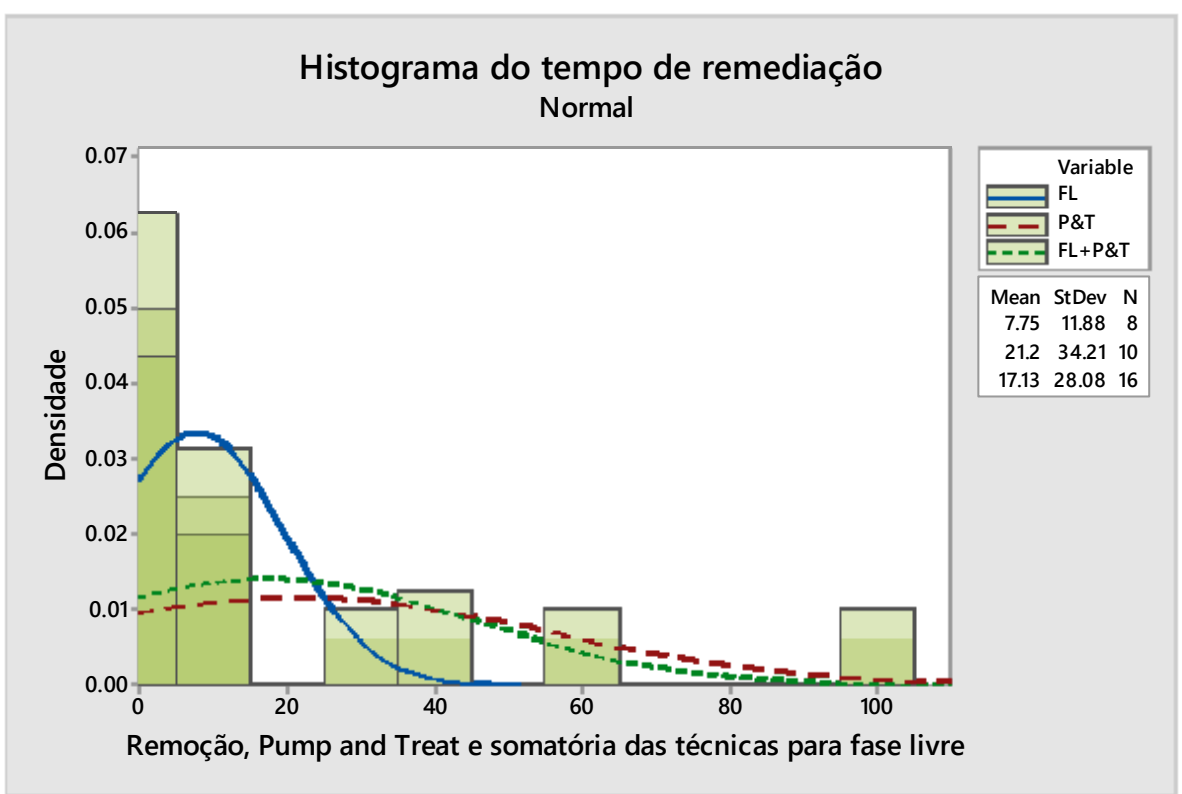

Análise dos prazos (mês) de remoção da fase livre: remoção, Pump \& Treat e
somatória das técnicas

Remocão fase livre (FL)

Média $=7,8$

Erro padrão $=4,20$

Desvio padrão $=11,88$

Mediana $=\quad 3,0$

$\mathrm{N}^{\circ}$ amostras $=8$
Pump \& Treat (P\&T)

Média $=$

21,2 Média $=17,3$

Erro padrão $=10,8 \quad$ Erro padrão $=7,02$

Desvio padrão $=\quad 34,2$

Desvio padrão $=28,08$

Mediana $=\quad 4,5 \quad$ Mediana $=\quad 5,5$

$\mathrm{N}^{\circ}$ amostras $=10 \quad \mathrm{~N}^{\circ}$ amostras $=16$

Gráfico 5.35 - Histograma dos prazos de remediação (REM) da fase livre pelas diversas técnicas observadas.

Assim, conclui-se que um período representativo médio para a aplicação da técnica de remoção da fase livre pelo P\&T é de 18 (dezoito) meses, abrangendo todos os casos analisados (acrescido da variância). 
A análise do histórico de aplicação da metodologia de remediação do P\&T sugere ser esta de melhor eficiência e aplicabilidade nos casos de vazamento de produtos pouco voláteis (diesel e óleos pesados), ou mesmo em contaminações recentes, de forma a eliminar, rapidamente, o produto. A área de ocorrência da fase livre deverá ser pequena (menor que $20 \mathrm{~m}^{2}$ ), pois grandes áreas de fase livre significam tempos longos de residência no subsolo e, consequentemente, ocorrência de fase vapor e dissolvida no subsolo.

\subsubsection{Prazos para a reparação da fase livre e vapor}

A técnica de remediação de combustíveis fósseis da Extração Multifásica (MPE) é a principal técnica utilizada no Estado de São Paulo, ocorrendo em 27,5\% dos casos de remediação, considerando o contingente de situações aqui analisadas nessa tese. Sua alta aplicação é decorrente de sua versatilidade e boa eficiência de uso em terrenos com solos de moderada abaixa condutividade hidráulica (característica típica dos solos intemperizados ricos em argilo minerais). O MPE apresenta boa atuação na diminuição da massa contaminante presente em fases livre e vapor no subsolo e, secundariamente, da massa em fases retida e dissolvida presentes.

Após a análise dos relatórios de Gerenciamento de Área Contaminada (GAC), o autor da tese indica a extração multifásica (MPE) como tecnologia de remediação da fase livre dos combustíveis fósseis, em detrimento do Pump \& Treat, para os casos de:

a) Remediação de grandes extensões de fase livre de produtos pesados (diesel) e leves (gasolina), por possibilitar um maior raio de atuação por poço de extração instalado e a ação de diminuição da massa das fases vapor e dissolvida, usualmente presentes devido ao longo tempo de residência do produto no subsolo.

b) Ocorrência de fase livre de produtos muito leves e mais voláteis (gasolina e querosene de aviação, por exemplo), independente da área, que, devido às suas características físico-químicas, volatilizam e se dissolvem na água em maior velocidade do que os combustíveis mais pesados. 


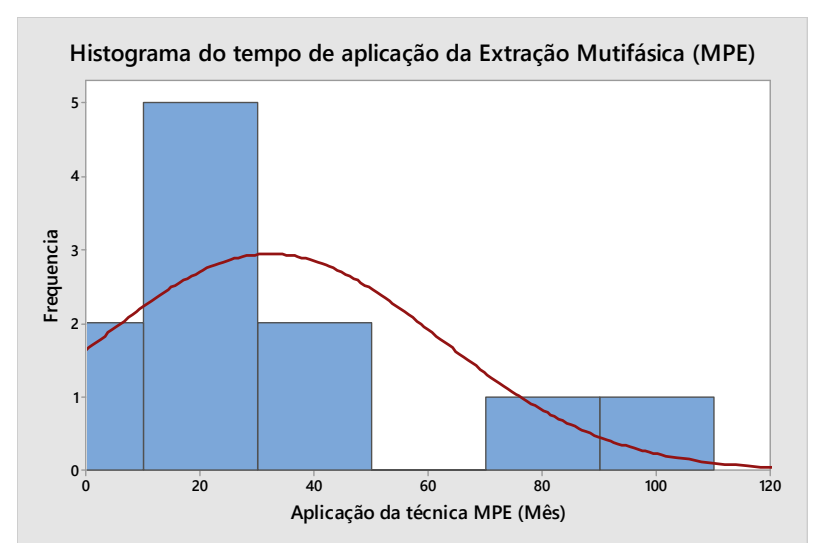

Análise do prazo (mês) da aplicação da Extração Multifásica - MPE

$\begin{array}{cc}\text { Média }= & 32,2 \\ \text { Erro padrão }= & 9,00 \\ \text { Desvio padrão }= & 29,84 \\ \text { Mediana }= & 19,0 \\ N^{0} \text { amostras }= & 11\end{array}$

Gráfico 5.36- Histograma da tempo de aplicação da técnica da extração multifásica (MPE), por área investigada.
Quando se avalia o período de operação da MPE em todos os casos estudados, verifica-se que a mesma é aplicada, em média, por 33 (trinta e três) meses (Gráfico 5.36). Entretanto, dos 11 (onze) casos analisados, em 5 (cinco) deles (45,5\% do total), houve a necessidade de aplicação de técnica complementar de diminuição da massa contaminante presente na água subterrânea (fase dissolvida).

Assim, os dados sugerem que a MPE é a tecnologia mais adequada para o tratamento das fases livre e vapor, e, secundariamente, da fase dissolvida, sendo aplicada ao longo de 32 (trinta e dois) meses, em média.

Entretanto, dois dos casos considerados (da área 5 e 10, com 98 e 75 meses, respectivamente) apresentam-se destoante em relação aos demais, que apresentam, em média, 20 (vinte) meses de operação.

\subsubsection{Prazos para a reparação da fase dissolvida e vapor}

Para os casos de tratamento da fase dissolvida na água, verifica-se a maior ocorrência da utilização, em conjunto, das tecnologias de Extração de Vapores (SVE) com a injeção de ar (Air Sparging - ASp). A aplicação destas duas técnicas em conjunto representa $25 \%$ dos casos de remediação de combustíveis fósseis no Estado de São Paulo, considerando o conjunto de casos analisados nessa tese. 


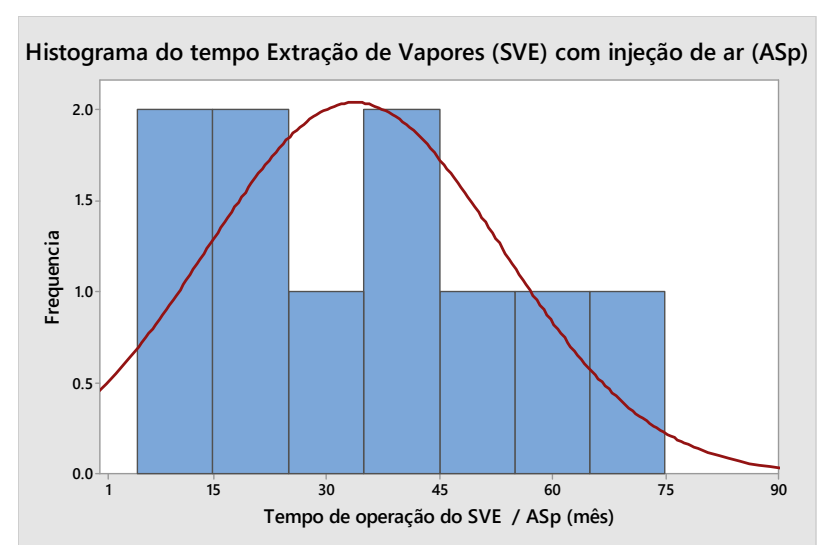

Análise do prazo (mês) da aplicação da

Extração de Vapores - SVE, com a injeção de ar - Asp

Média $=$ 33,8

Erro padrão $=6,19$

Desvio padrão $=19,57$

Mediana $=35,50$

$N^{0}$ amostras $=10$

Gráfico 5.37- Histograma do tempo de aplicação da técnica da extração multifásica (MPE), por área investigada.
A tecnologia do SVE/ASp apresenta, como vantagem, em relação a Oxidação Química (ISCO) que é utilizada em 15\% das remediações, a diminuição da massa de vapor dos compostos voláteis no subsolo em conjunto com a diminuição da massa da fase retida no solo situado na zona não saturada.

O sistema SVE / ASp foi operado em 10 (dez) das áreas, em média, por 34 (trinta e quatro) meses, com variação de 20 (vinte) meses, conforme ilustra o histograma apresentado no Gráfico 5.37.

Em apenas um dos casos analisados, 0 sistema foi complementado pela ISCO, sugerindo uma boa eficiência, quando bem dimensionado.

\subsubsection{Prazos para a reparação da fase dissolvida}

Para a reparação da fase dissolvida, a diminuição da massa contaminante na água, verifica-se a utilização da Oxidação Química (ISCO) e a Atenuação Natural Monitorada (ANM), aplicadas em 6 (seis) casos cada (15\% do total das áreas remediadas). Em uma das áreas, a ANM foi aplicada após a ISCO. A análise dos registros pelo autor da tese indica que a ISCO apresenta melhores resultados quando não existe risco associado às fases retidas e vapor, ou mesmo, fase livre.

O histórico de aplicação da ISCO e ANM indica que, na maioria dos casos, são técnicas complementares a outras previamente aplicadas, efetuando o "polimento" do resultado final da fase dissolvida efetuada pelas técnicas anteriores. 
A ISCO é usualmente aplicada através de 4 (quatro) fases de injeções de oxidantes no subsolo, com período de 3 (três) meses entre as mesmas, representando, em teoria, um período total de 9 (nove) meses de remediação com o monitoramento de eficiência e eficácia entre as aplicações. Entretanto, em uma das áreas (Área $n^{\circ} 7$ ), essa técnica foi aplicada sem continuidade e com grandes períodos de inatividade da operação da remedição, perfazendo um período total de 188 (cento e oitante oito) meses, não representativo de um processo contínuo e, assim, não foi considerado na análise estatística.

Os dados analisados indicam que a ISCO é aplicada, em média, ao longo de 21 (vinte e um) meses, mais que o dobro do que indica a bibliografia especializada, conforme ilustra a Gráfico 5.38. Não foi observada uma constância nos prazos de aplicação da metodologia, sendo diferente (diferença maior que 25\%) para cada uma das áreas analisadas, com aplicações de forma não contínua. Estima-se que a aplicação da metodologia ISCO sob condições ideais são necessários 16 (dezesseis) meses.

Já a ANM apresenta difícil análise, pois os casos somente são possíveis de serem identificados quando se cruzam as informações com o cadastro de áreas contaminadas da CETESB, uma vez que, nenhum dos relatórios analisados indica o desenvolvimento da ANM, apesar de 4 (quatro) das área constarem na lista de área contaminada da CETESB (2018) como tendo desenvolvido ou em desenvolvimento. Os relatórios apresentam os registros apenas como em etapa de Monitoramento para o Encerramento (ME), que, em média, são efetuados ao longo de 15 (quinze) meses (período menor que o estabelecido pela DD 38 da CETESB), conforme apresentado no Gráfico 5.39. 


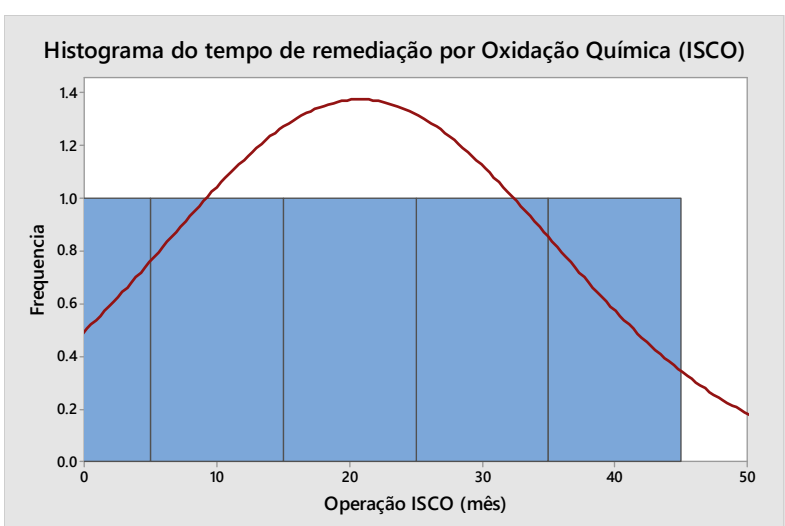

Análise do prazo (mês) da aplicação da Oxidação Química

Média $=$ 20.8

Erro padrão $=$ 6,49

Desvio padrão = 14,52 Mediana $=$ 24,0

$\mathrm{N}^{\circ}$ amostras $=$

Gráfico 5.38 - Histograma do prazo de aplicação da Oxidação Química (ISCO), por área investigada.

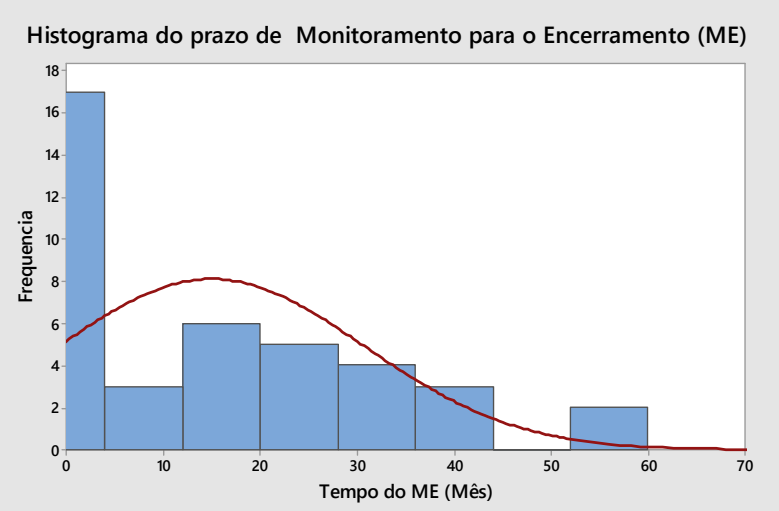

Análise do prazo de monitoramento para o encerramento ou Atenuação Natural Monitorada (ANM) (mês) Média $=\quad 15,0$ Erro padrão $=\quad 2,49$ Desvio padrão $=\quad 15,74$ Mediana $=\quad 11,0$ $\mathrm{N}^{\circ}$ amostras $=40$

Gráfico 5.39 - Histograma do prazo de monitoramento para o encerramento ou Atenuação Natural Monitorada (ANM), por área investigada.

\subsubsection{Conclusões preliminares sobre os sistemas de remediação do dano reversível implantado}

Os casos avaliados indicam que os sistemas de remediação do dano reversível são projetados e instalados de forma a aproveitar as estruturas pré-existentes (poços, linhas de bombeamento, etc.), entre outros fatores. Esta prática, de uma forma geral, negligencia uma melhor eficiência ou eficácia de um projeto customizado para as condições locais em favor de um investimento inicial menor. Entretanto, tal prática pode contribuir para um maior prazo de operação dos sistemas de remediação e, consequentemente, um custo maior ao final das etapas de Gerenciamento de Áreas Contaminadas.

De uma forma geral, os sistema de remediação in situ das área é composto do sistema de extração da massa contaminante e/ou de injeção de produto no subsolo, rede de operação e distribuição do sistema, e um sistema de tratamento dos contaminantes e de controle e operação do mesmo em superfície. 
O autor dessa tese entende que, de uma forma simplificada, para fins de estimativas de custos de contratação do projeto detalhado de remediação, implantação e operação do sistema, deve-se definir:

$\checkmark$ Metodologia e objetivos da remediação e prazo de operação.

$\checkmark$ Área de atuação do sistema e contaminante a remediar, profundidade do nível freático, características do contaminante.

$\checkmark$ Número básico de dispositivos de extração e/ou injeção e distância entre a área a remediar e a localização do sistema de tratamento e controle superficial a ser instalado.

Os documentos avaliados indicam que, em média, os equipamento superficiais distam $50 \mathrm{~m}$ da área de remediação. Foram definidos pelo autor desta pesquisa, considerando a análise das características dos sistemas de remediação operadas em 28 (vinte e oito) das 44 (quarenta e quatro) áreas avaliadas (Tabela 5.7), as seguintes unidades básicas de remediação:

a) Sistema Pump \& Treat (P\&T)

3 (três) poços de extração a cada $60 \mathrm{~m}^{2}$ de fase livre identificada, em média, com 1 (um) poço de injeção de água residual, representando 1 (um) poço de bombeamento para cada $20 \mathrm{~m}^{2}$. Entretanto o sistema pode ter ou não poços de injeção de água residual, em função da facilidade de descarte da mesma.

b) Sistema multifásico (MPE).

Os dados indicam uma média de 6 (seis) poços de extração a cada $300 \mathrm{~m}^{2}$, aproximadamente, com 2 (dois) poços de injeção de água residual, representando uma célula de MPE composta de 3 (três) poços de extração e 1 (um) de injeção a cada $150 \mathrm{~m}^{2}$. Assim como no sistema P\&T, a existência de poços de injeção pode variar em função da facilidade local de descarte da água residual.

c) Sistema combinado de Extração de vapores (SVE) / Air Sparging (ASp)

O sistema combinado de remediação Extração de vapores (SVE) / Air Sparging (ASp) apresenta uma média aritmética simples de 6 (seis) poços de extração e 2 (dois) de injeção de ar para $300 \mathrm{~m}^{2}$, aproximadamente, indicando uma célula básica de 3 (três) SVE / 1 (um) ASp para cada $150 \mathrm{~m}^{2}$. 
d) Sistema de oxidação química (ISCO)

Em média, foram utilizados 13 pontos de injeção para cada $600 \mathrm{~m}^{2}$, indicando um padrão de 3 pontos de injeção para $150 \mathrm{~m}^{2}$ de célula básica. Muitos dos documentos não indicam o número de injeções efetuadas, mas consultas informais efetuadas no mercado indicam que, em geral, são efetuadas até 4 injeções de produtos oxidantes a cada 3 (três) meses.

Tabela 5.7 - Análise simples dos principais dispositivos dos sistemas de remediação da zona saturada.

\begin{tabular}{|c|c|c|c|c|c|c|c|c|c|c|c|c|}
\hline \multirow[b]{2}{*}{ ID } & \multirow[b]{2}{*}{ Posto } & \multicolumn{3}{|c|}{ P\&T } & \multicolumn{3}{|c|}{ MPE } & \multicolumn{3}{|c|}{ SVE / ASp } & \multicolumn{2}{|c|}{ ISCO } \\
\hline & & PE & $\mathrm{PI}$ & Área & PE & PI & Área & SVE & Asp & Área & $\mathbf{P i}$ & Área \\
\hline 1 & 5 & 1 & 0 & 9 & & & & & & & & \\
\hline 2 & 6 & 1 & 0 & 250 & & & & & & & 6 & 500 \\
\hline 3 & 7 & 5 & 2 & 60 & 10 & 3 & 600 & & & & 10 & 600 \\
\hline 4 & 8 & 1 & 1 & 10 & & & & & & & 5 & 1400 \\
\hline 5 & 9 & 7 & 0 & 70 & & & & & & & & \\
\hline 6 & 10 & 2 & 0 & 10 & & & & & & & & \\
\hline 7 & 11 & 1 & 0 & 6 & & & & & & & & \\
\hline 8 & 12 & & & & & & & & & & 42 & 650 \\
\hline 9 & 13 & & & & & & & & & & 3 & 50 \\
\hline 10 & 14 & 5 & 0 & 150 & & & & 7 & 3 & 300 & & \\
\hline 11 & 18 & 2 & 1 & 25 & 5 & 2 & 50 & & & & & \\
\hline 12 & 23 & 2 & 1 & 20 & & & & & & & & \\
\hline 13 & 25 & 2 & 2 & 30 & 9 & 2 & 300 & & & & & \\
\hline 14 & 27 & 1 & 0 & 5 & & & & & & & & \\
\hline 15 & 28 & 1 & 0 & 5 & & & & & & & & \\
\hline 16 & 29 & & & & & & & 8 & 4 & 150 & & \\
\hline 17 & 31 & 2 & 1 & 240 & 1 & 0 & & & & & & \\
\hline 18 & 32 & 1 & 0 & 5 & & & & 5 & 2 & 500 & & \\
\hline 19 & 33 & & & & 5 & 1 & 350 & 8 & 3 & 550 & & \\
\hline 20 & 35 & & & & 4 & 1 & 300 & & & & & \\
\hline 21 & 36 & & & & 9 & 1 & 600 & & & & & \\
\hline 22 & 38 & & & & 4 & 1 & 150 & & & & & \\
\hline 23 & 39 & 1 & 0 & 150 & 5 & 3 & 50 & 3 & 1 & 200 & & \\
\hline 24 & 40 & & & & & & & 7 & 3 & 300 & & \\
\hline 25 & 41 & & & & & & & 6 & 2 & 200 & & \\
\hline 26 & 42 & & & & & & & 3 & 1 & 350 & & \\
\hline 27 & 43 & & & & 6 & 1 & 300 & & & & & \\
\hline 28 & 44 & 2 & 0 & 10 & 4 & 2 & 10 & 6 & 2 & 350 & 14 & 400 \\
\hline & dia & 3 & 1 & 63,00 & 6 & 2 & 283 & 6 & 2 & 322 & 13 & 600 \\
\hline
\end{tabular}

PE - Poço de extração; Pi - Poço de injeção; Área - Área de atuação do sistema; P\&T - Pump \& Treat; MPE - Remediação multifásica; SVE/ASp - Extração de vapores / Air Sparging; ISCO - Oxidação Química; Média - Média aritmética simples; Máx - Mínimo valor considerado; Máx - Mínimo valor considerado 


\section{PROPOSTA PARA A QUANTIFICAČÃO PARA A VALORAČ̃̃O DO DANO AMBIENTAL REVERSÍVEL}

Para a quantificação das ações de investigação e remediação do dano reversível é proposta uma metodologia de Estimativa Baseada na Investigação Confirmatória, aqui denominada de EBIC, tendo por base as análises dos dados das áreas contaminadas, conforme descrito a seguir:

\subsection{PROPOSTA DA QUANTIFICAÇÃO PARA A VALORAÇÃO DAS ATIVIDADES DE INVESTIGAÇÃO DA ÁREA CONTAMINADA}

Para a valoração do dano ambiental, inicialmente devem ser definidos os quantitativos básicos da investigação ambiental necessários para a execução da Investigação Detalhada (ID) e Análise de Risco (ARtx). Com a quantificação das ações necessárias, é possível obter o valor das mesmas no mercado através de simples cotação em uma ou mais empresa especializada.

Considerando que a contaminação do imóvel pode ocorrer ou não em toda a sua extensão, ou até mesmo, ultrapassar seus limites e abranger mais de um imóvel (assim como bens ambientais), a delimitação da ocorrência da Área Fonte de contaminação ( $\left.A F_{\text {cont }}\right)$, bem como a data de contaminação $\left(T_{0}\right)$ é fator inicial de caracterização da influência no dano ambiental.

A característica da $A F_{\text {cont }}$ poderá variar em função do empreendimento e do sistema de armazenamento, distribuição e abastecimento de combustível. Um imóvel poderá possuir uma única $\mathrm{AF}_{\text {cont }}$ ou mais de uma, e o contaminante possui, em sua fase inicial, uma dinâmica vertical de infiltração no subsolo. Assim, a Área de Investigação dos contaminantes na zona não saturada ( $\mathrm{Al}_{\mathrm{z} n \mathrm{~s}}$ ) com potencial de ocorrência de fase retida é dada pelo número de $A F_{\text {cont }}$ caracterizadas ou Área Suspeitas de contaminação, delimitada durante a Avaliação Preliminar (AvP), expandidas 2,0 m em seus limites. 
Entretanto, os trabalhos de Investigação Confirmatória (IC) podem não delimitar corretamente a $\mathrm{AF}_{\text {cont, }} \mathrm{e}$, assim, esta deve ser entendida como área de referência inicial. Considerando o tamanho do tanque de armazenamento padrão, assim como os dados base contidos nas planilhas de avaliação de risco à saúde de áreas contaminadas sob investigação da CETESB (CETESB - 2013, que devem ser aplicadas na quantificação do risco à saúde humana em áreas contaminadas no Estado de São Paulo), é possível definir que a menor $\mathrm{AF}_{\text {cont }}$ a ser considerada será de 4,5 (L) x 4,5 m (C), que, estendida $2 \mathrm{~m}$ de seus limites, será de $42,25 \mathrm{~m}^{2}$.

A metodologia proposta reconhece e considera as atividades envolvidas na investigação e remediação do dano ambiental, mas não detalha particularidades de cada área ou processo, devido a sua complexidade e a diversidade das peculiaridades envolvidas em cada caso. Entretanto, possibilita estabelecer uma base para sua valoração, mesmo com as dificuldades e incertezas inerentes ao tema, que norteará o planejamento do correto Gerenciamento de Áreas Contaminadas (GAC), conforme fluxograma proposto na Figura 6.1.

Considerando o fluxograma proposto, haverá a necessidade de, no mínimo, 5 (cinco) sondagens de investigação da Fase Retida $(F R)$ para cada $A F_{\text {cont, }}$ com o total de sondagens por área em função de seu tamanho a uma razão de uma sondagem a cada $10 \mathrm{~m}^{2}$. A profundidade de cada sondagem de investigação da fase retida será dada pela profundidade do nível de água, havendo 2 coletas de amostras de solo para cada furo, uma superficial e outra na franja capilar para quantificação laboratorial de BTEX (Benzeno, Tolueno, Etilbenzeno e Xileno) e PAH (Hidrocarboneto Poliaromático) em cada amostra coletada, perfazendo um mínimo de 10 (dez) análises de cada parâmetro.

Considerando a direção preferencial de fluxo subterrâneo caracterizado na IC, tendo

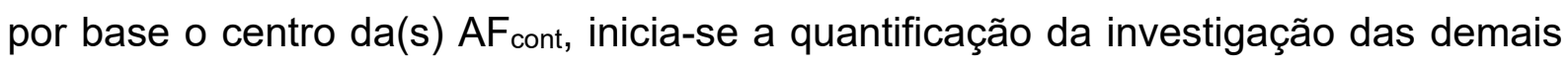
fases contaminantes, tendo por base a área potencial da fase dissolvida (AFD). 


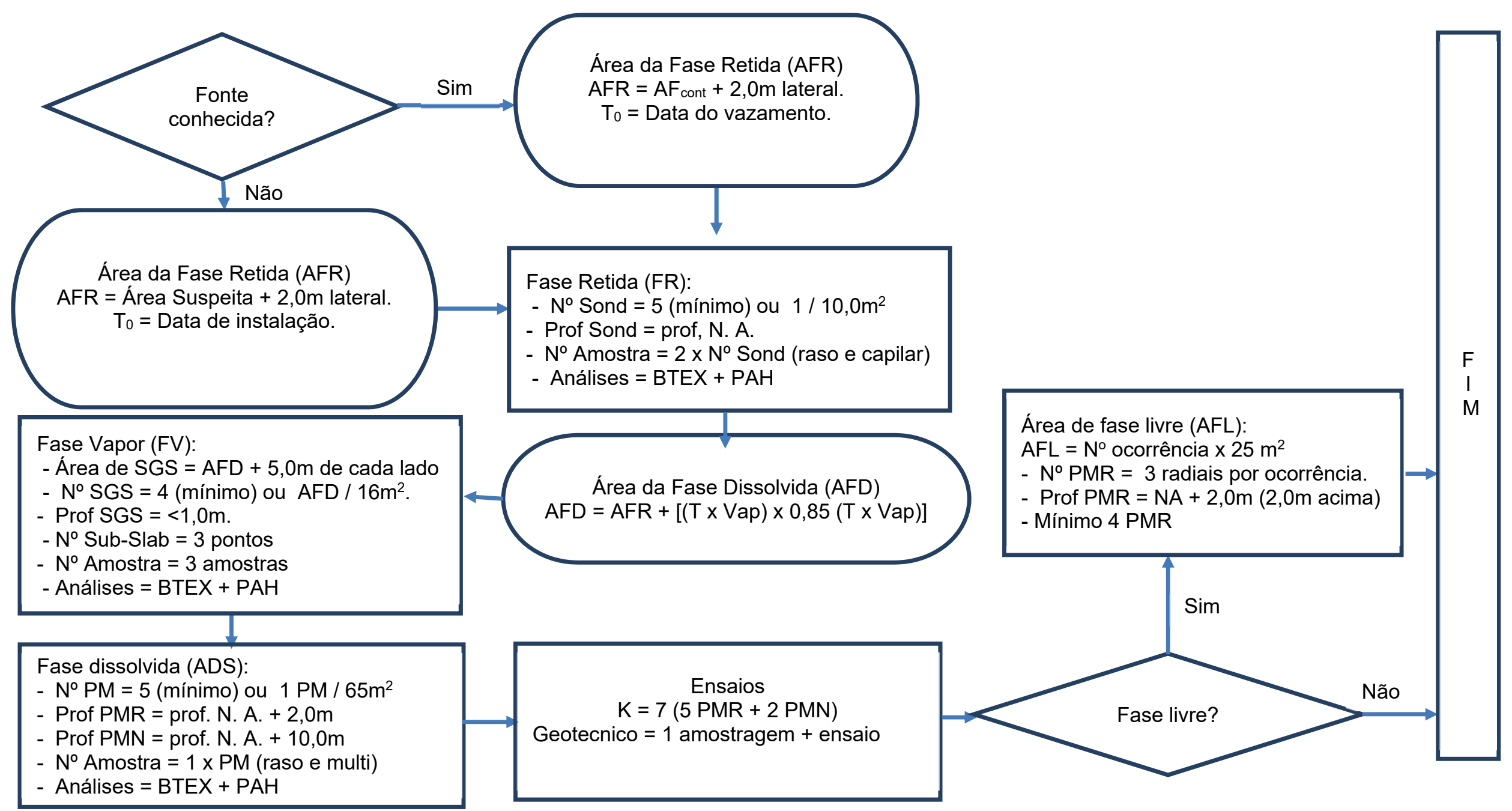

SGS - Soil Gas Survey; T - Tempo transcorrido entre a contaminação ( $\left.T_{0}\right)$ e a data de cálculo; Vap- velocidade aparente de fluxo; K-Coeficiente de condutividade hidráulica; BTEX- Benzeno, Tolueno, Etilbenzeno e Xileno; PAH- Hidrocarboneto Poliaromático.

Figura6.1 - Proposta de fluxograma de quantificação de atividades de investigação da contaminação. 
Para o cálculo da AFD, deve-se considerar o comprimento dado pela velocidade aparente de fluxo subterrâneo aparente (Vap) multiplicado pelo tempo de deslocamento (compreendido pela diferença da data do cálculo e a data da contaminação, $T_{0}$ ). Quando se desconhece o $T_{0}$, deve-se considerar a data de instalação da área fonte ou do empreendimento. A largura da AFD será equivalente a 0,85 do comprimento calculado. Assim, para a quantificação da AFD, é proposta a Equação 6.1:

$$
\text { AFD }=A F R+[(T \times \text { Vap }) \times 0,85(T \times \text { Vap })][\text { Equação 6.1] }
$$

Onde:

$$
\begin{aligned}
& \text { AFD = área potencial de ocorrência da fase dissolvida }\left(\mathrm{m}^{2}\right) . \\
& \text { AFR = área potencial de ocorrência da fase retida }\left(\mathrm{m}^{2}\right) . \\
& \text { Vap = velocidade aparente de fluxo (m/dia).. } \\
& \mathrm{T}=\text { tempo transcorrido entre a contaminação }\left(\mathrm{T}_{0}\right) \text { e a data de cálculo (dia). }
\end{aligned}
$$

A proposta considera que a área para investigação da fase vapor através do SGS (Soil Gas Survey) é dada pela AFD acrescida de 5,0 m em cada lateral (margem de erro aqui adotado), com um ponto a cada $16,0 \mathrm{~m}^{2}$, com perfurações de menos de um metro de profundidade.

Apesar de não haver a prática de efetuar a quantificação da fase vapor, conforme evidenciam os documentos analisados, sua ausência é fator de dificuldade na definição da remediação do dano reversível e, consequentemente, na obtenção da reabilitação da área. Para a investigação e quantificação da ocorrência de gases e vapores orgânicos no subsolo, a fase vapor dos contaminantes, devem ser instalados poços de monitoramento na zona não saturada tipo sub-slab, e, assim, ser possível a quantificação de uma possível intrusão de vapores na área. É recomendável que ocorra, no mínimo, 3 (três) pontos de coleta de amostras de vapor e quantificação de BTEX e PAH na área, distribuídos conforme a geometria de ocorrência da fase vapor mapeada através da SGS. 
Para a quantificação e delimitação da fase dissolvida, a proposta considera que deve ser instalado, um poço de monitoramento raso a cada 65,0 $\mathrm{m}^{2}$ (no mínimo 5 - cinco poços), distribuídos ao longo da AFD potencial, considerando os resultados do SGS. Devem ser instalados, também, 2 (dois) poços multiníveis, um próximo a $A F_{\text {cont }}$ e outro no centro da AFD. Os poços de monitoramento rasos e multiníveis devem ser instalados com profundidades totais em função da profundidade do nível freático (N.A.) local, o primeiro com sua base $2,0 \mathrm{~m}$ abaixo do N.A., enquanto que os multinível, 7,0 m abaixo do N.A..

Considera, ainda, que será necessário a coleta de amostras de água em todos os poços instalados e análises de quantificação para BTEX e PAH e 7 (sete) ensaios de permeabilidade, sendo 2 (dois) deles efetuados no poço multinível, além de uma amostragem de solo indeformada para caracterização dos parâmetros geotécnicos, representativo da litologia solo predominante que o contaminante está presente.

Caso não exista fase livre, a quantificação das atividades de investigação para a ID e ARtx está terminada. Entretanto, caso tenha sido detectada a presença de fase livre quando da IC, deve ser prevista, ainda, a instalação de 3 (três) poços de monitoramento específicos para cada ponto de ocorrência de fase livre identificado na IC, com a instalação de, no mínimo, 4 (quatro) poços na área para a delimitação da fase livre. Para a sua locação, deve-se considerar o número de ocorrência de ponto de fase livre e estimar uma área potencial de ocorrência de 25,0 $\mathrm{m}^{2}$ (5,0 x 5,0 m) para cada ponto de ocorrência. O perfil construtivo dos poços deve possibilitar a monitoramento ao longo da variação sazonal N.A. e, assim, deve ser projetado para possuir 2,0 m de seção filtrante acima e abaixo do freático.

Para fins de estimativa do tempo necessário da investigação da área contaminada até a obtenção dos dados básicos necessários para o início do projeto de remediação, o autor desta tese recomenda considerar, de forma conservadora, um período de 9 (nove) meses, acrescidos de 3 (três) meses para a contratação e o início da mesma. 


\subsubsection{Calibração e validação da quantificação das atividades de investigação}

De forma a obter a calibração e validação da metodologia de Estimativa Baseada na Investigação Confirmatória (EBIC) para a quantificação da investigação da área contaminada, foram efetuadas simulações de quantificação das atividades de investigação da área contaminada através da utilização de informação de uma 8 (oito) áreas contaminadas diferentes, inserindo-se os dados básicos caracterizados na Investigação Confirmatória (IC), conforme ilustra o Quadro 6.1.

Quadro 6.1 - Dados básicos considerados para a quantificação na planilha EBIC (tela de saída da planilha EBIC)

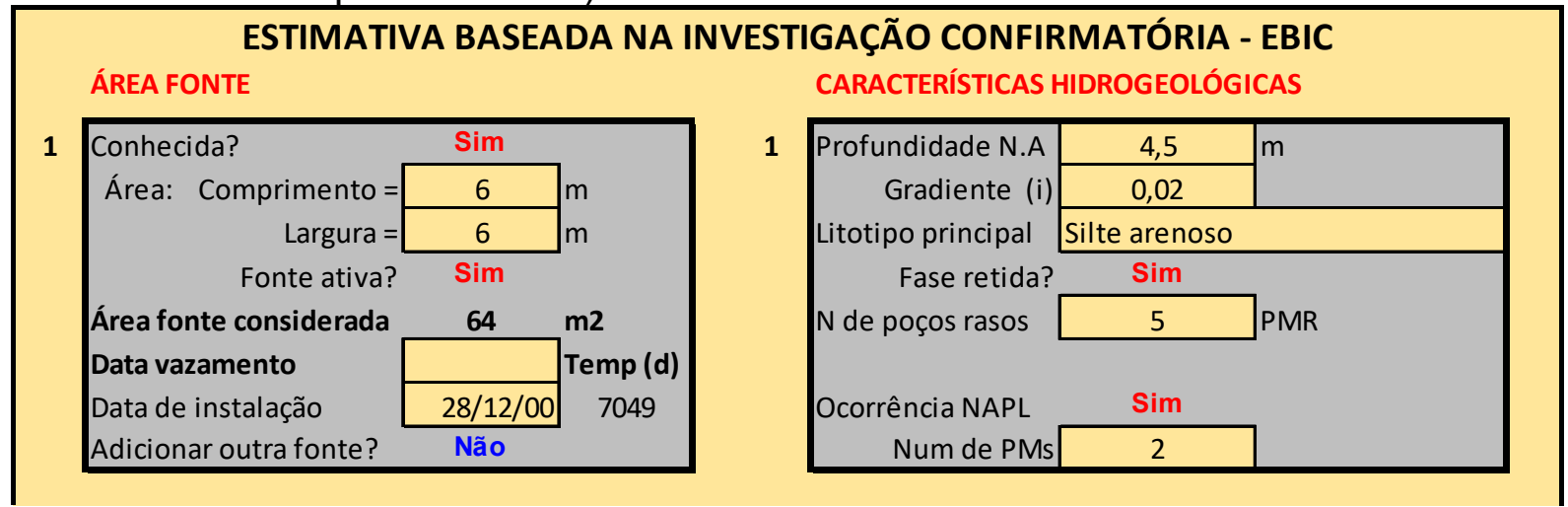

As simulações efetuadas dos quantitativos através da planilha EBIC (Quadro 6.2), apresentou-se coerente com as práticas do mercado, apesar de considerar os dados representativos para investigação da fase vapor, pouco efetuada na prática, até a presente data.

Assim, para a quantificação das atividades de investigação, a metodologia EBIC foi considerada calibrada. Entretanto, a validação de seu resultado é de difícil avaliação, uma vez que, consultas no mercado apresentam grande variação dos quantitativos, pois:

a) As empresas tendem a apresentar o menor quantitativo possível, de forma a minimizar o valor final da proposta.

b) Possíveis deficiências dos resultados da investigação, podem ser justificadas (pós investigação inicial) e complementadas através de futuros trabalhos adicionais de investigação a ser negociado com o cliente. 
Quadro 6.2 - Resultados da quantificação da planilha EBIC para a investigação do dano ambiental

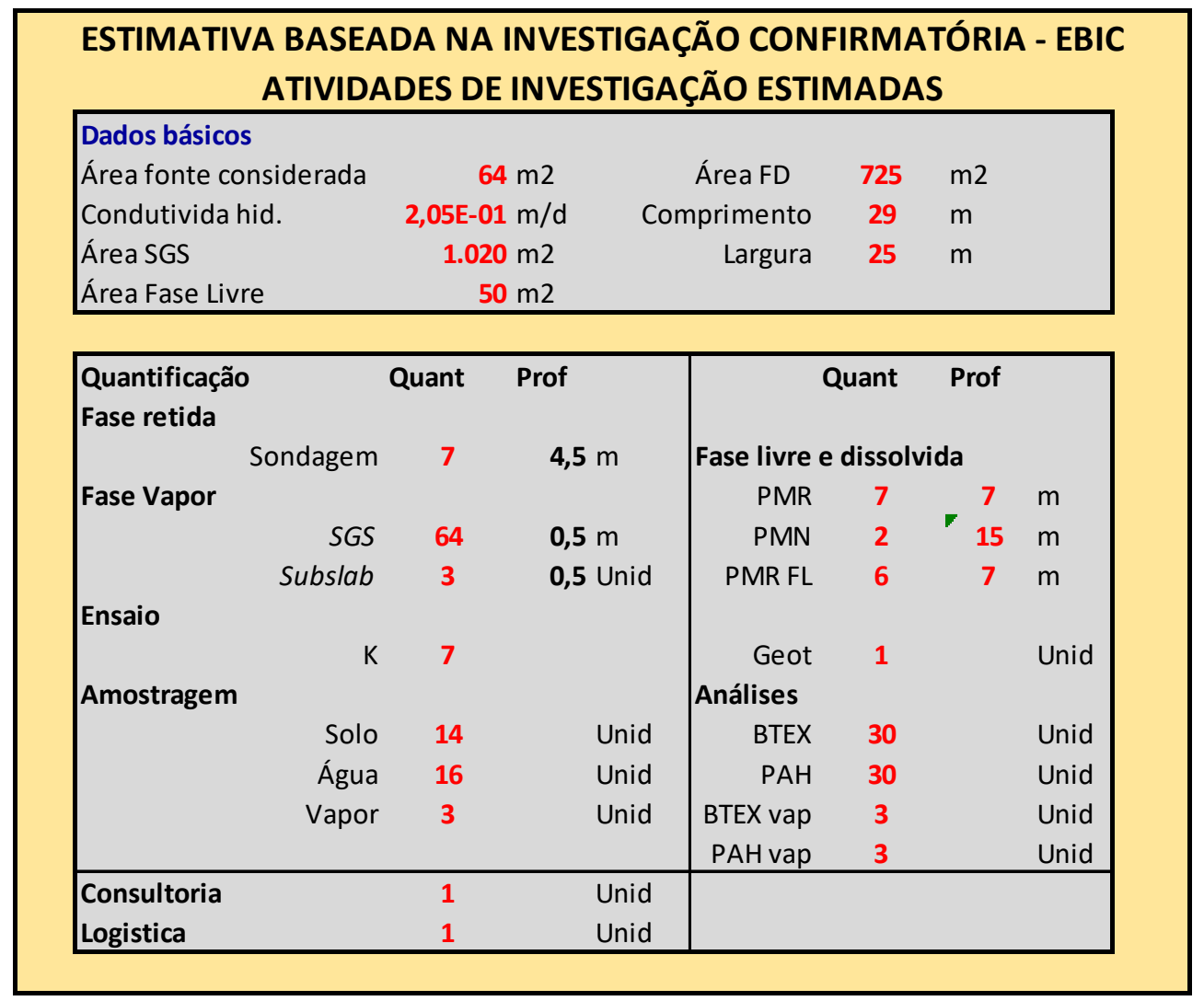

Para os quantitativos apresentados na planilha EBIC, apresentado, no Quadro 6.2, o autor efetuou 3 (três) cotações com empresas de expressão regional, nacional e internacional, de forma a obter a valoração das atividades de investigação do dano ambiental. Os resultados da valoração indicam um investimento médio de $\mathrm{R} \$ 181.203,06$ (cento e oitenta e um mil, duzentos e três reais e seis centavos) para o desenvolvimento da Investigação Detalhada, conforme apresentados no Quadro 6.3. Os resultados apresentaram-se coerentes com a prática do mercado, e, assim, foi considerado calibra do e validado, apesar das ressalvas efetuadas anteriormente.

Quadro 6.3 - Valoração da quantificação da planilha EBIC para a investigação do dano ambiental

\begin{tabular}{|c|c|c|c|c|}
\hline \multicolumn{5}{|c|}{$\begin{array}{c}\text { ESTIMATIVA BASEADA NA INVESTIGAÇÃO CONFIRMATÓRIA - EBIC } \\
\text { EMPRESA DE CONSULTORIA AMBIENTAL }\end{array}$} \\
\hline & Pequena & Média & Grande & R\$̦/Médio \\
\hline Valor ID & $\mathrm{R} \$ 118.914,51$ & $\mathrm{R} \$ 169.877,87$ & $\mathrm{R} \$ 254.816,81$ & $\mathrm{R} \$ 181.203,06$ \\
\hline Valor AR & $R \$ 14.235,21$ & $R \$ 20.336,02$ & $R \$ 25.000,00$ & $\mathrm{R} \$ 19.857,08$ \\
\hline
\end{tabular}




\subsection{PROPOSTA DE QUANTIFICAÇÃO PARA A VALORAÇÃO DAS ATIVIDADES DE RECUPERAÇÃO DO DANO REVERSíVEL}

Para a quantificação e posterior valoração das atividades de recuperação do dano reversível, a remediação da área contaminada, é proposto o procedimento de estimativa das atividades conforme fluxograma de decisão apresentado na Figura 6.2.

A proposta de quantificação das atividades de recuperação do dano reversível, inicialmente, tem como a primeira grande questão a identificação da necessidade legal de efetuar ou não a remediação do dano reversível que, a princípio, somente é estabelecido com o desenvolvimento da Análise de Risco Toxicológico (ARtx), tendo por base a Investigação Detalhada (ID), conforme preconiza a DD38/2017 da CETESB e ABNT NBR 16209 (2013, Avaliação de risco a saúde humana para fins de gerenciamento de áreas contaminadas) e NBR15515-3 (2013, Avaliação de passivo ambiental em solo e água subterrânea - Parte 3: Investigação detalhada), que, ainda não foram desenvolvidos na área em avaliação, para a primeira tomada de decisão.

Assim, a metodologia de Estimativa Baseada na Investigação Confirmatória (EBIC) proposta nesta tese, define a execução de uma ARtx preliminar da área, de forma qualitativa, considerando o modelo conceitual, concentrações máximas e profundidade do nível freático caracterizadas na Investigação Confirmatória (IC), bem como as áreas impactadas estimadas conforme proposto para a quantificação das atividades de investigação citadas no item anterior e as características físicas do solo em função de sua litologia predominante.

Apesar desta ARtx qualificativa não ser válida para a quantificação dos riscos conforme preconiza a DD38 da CETESB, uma vez que não atenderá todos os requisitos legais especificados, por utilizar dados conservadores da própria planilha de cálculo de risco, fornecerá uma estimativa da necessidade ou não de se efetuar uma remediação do dano reversível. 


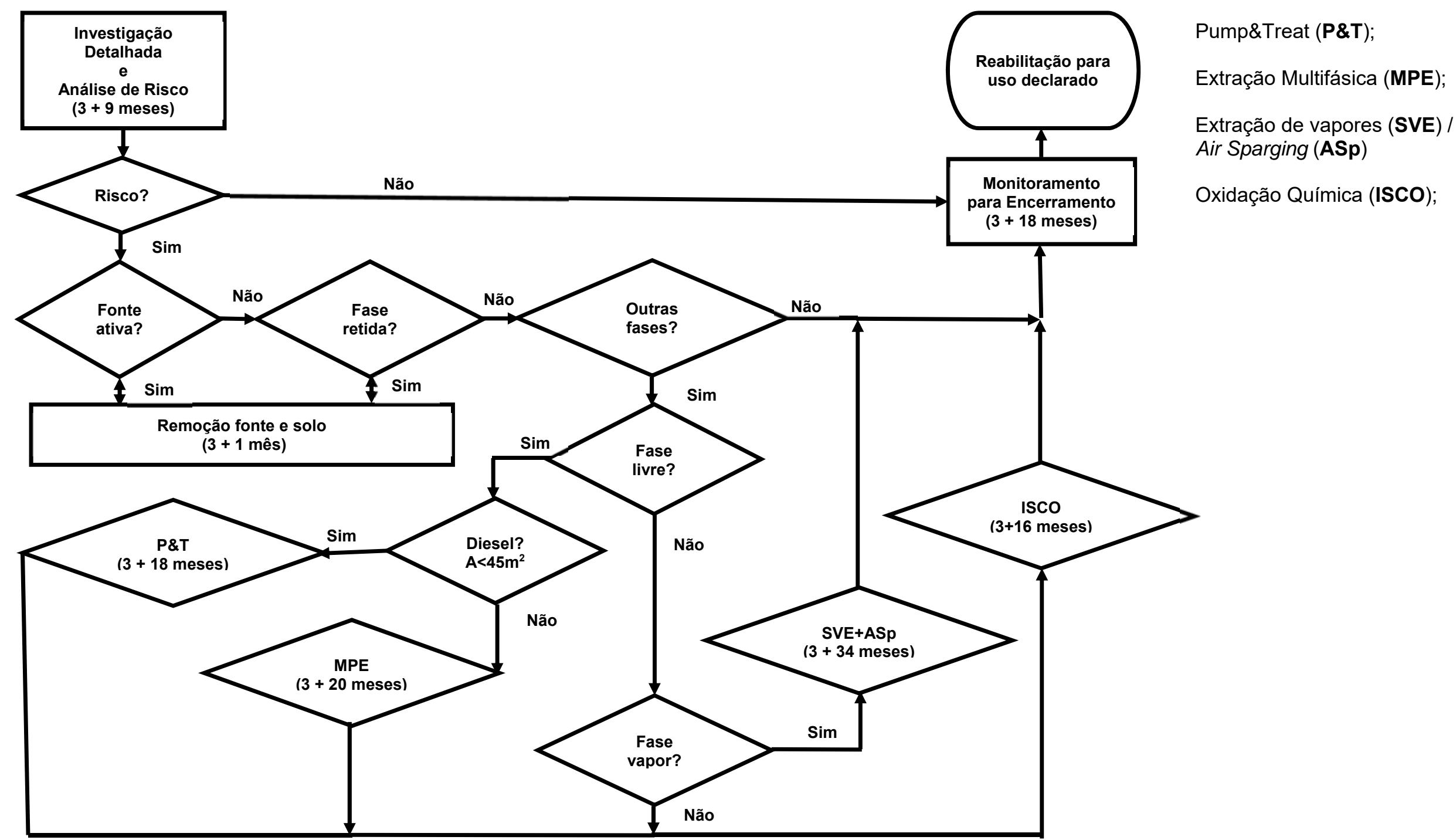

Figura 6.2 - Proposta de fluxograma de quantificação de atividades de recuperação do dano reversível 


\subsubsection{Situação de não necessidade de remediação do dano reversível}

Caso não seja estimado um risco qualificativo associado à área, deve-se considerar apenas a necessidade do desenvolvimento da Investigação Detalhada (ID) e a Análise de Risco Toxicológico (ARtx), seguido do Monitoramento para Encerramento (ME, compreendimento por 4 - quatro - campanhas semestrais), conforme estabelecido na DD38/2017. Para esta situação, as atividades da ID já foram quantificadas (e podem ser valoradas no mercado) na etapa de quantificação da investigação.

A ARtx, assim como o Plano de Intervenção (PI), são trabalhos executados por empreitada em função da quantidade dos dados existentes, considerando os dados da ID e, assim, também podem ser cotados.

A proposta considera, para a realização da ID e ARtx, um prazo conservador de 12 (doze) meses, sendo 3 (três) meses para a contratação e início da ID e 9 (nove) meses para a atividade em si.

Para o ME, para fins de estimava de seus custos, a proposta considera que devem ser utilizados os mesmos quantitativos de coleta e análises de água subterrânea previsto para a investigação da área contaminada. O prazo de desenvolvimento da ME é estimado em 18 (dezoito) meses, acrescido de 3 (três) meses, o tempo necessário entre a ARtx e início da ME. Assim, para esta situação, estima-se um período total de 28 (vinte e oito) meses para a obtenção da reabilitação da área, conforme sequência de fluxo de decisão destacado em vermelho, apresentado na Figura 6.3.

\subsubsection{Situação de necessidade remediação do dano reversível}

Caso as condições ambientais da área em avaliação apresentem risco toxicológico a saúde humana qualitativo, devem ser previstas ações de diminuição da massa do contaminante presente no meio (entre outras ações) que elimine o risco, conforme previsto na DD38/2017. 


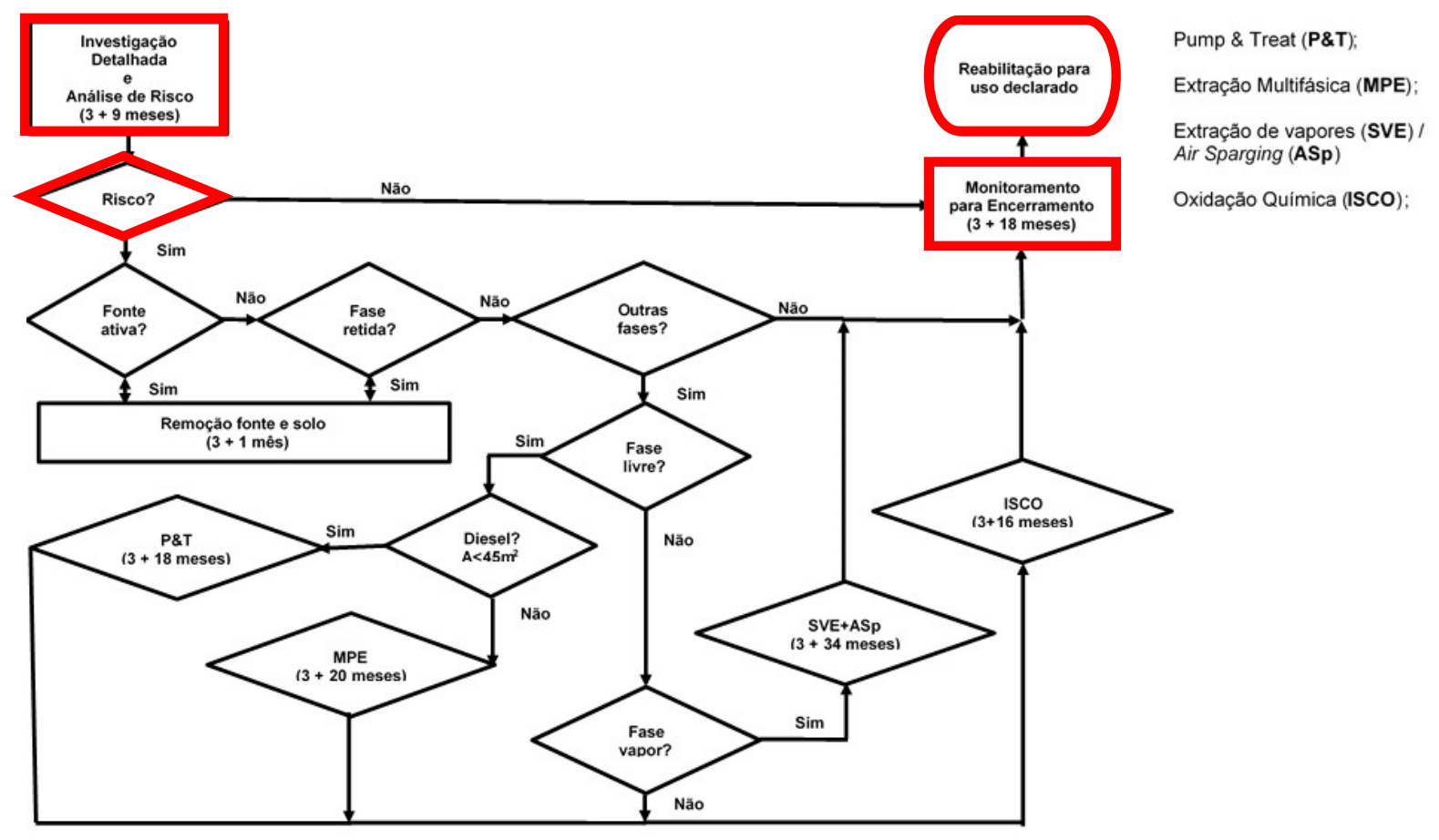

Figura 6.3 - Sequência de fluxo de decisão para a situação de não existência de risco (destacado em vermelho).

Entendemos que o projeto executivo da remediação, presente no Plano de Intervenção (PI) a ser apresentado para a CETESB, neste caso, é parte da remediação em si e, assim, seus custos estão inclusos na avaliação das metodologias e do projeto de remediação do dano reversível, conforme tecnologias de remediações consideradas nos subitens descritos a seguir:

Assim, quando da cotação do sistema de remediação, esta deverá prever o PI e a parte de consultoria de dimensionamento e instalação do sistema do próprio sistema de remediação na área, bem como sua operação, manutenção e os devidos monitoramentos de eficácia e eficiência registrados em relatórios técnicos mensais.

Para todos os casos, o(s) sistema(s) de remediação deverá(ão) considerar a profundidade do nível de água e concentrações máximas obtidas na Investigação Confirmatória, bem como as características de ocorrência do contaminante, estimadas conforme preconiza descrito anteriormente. 
6.2.2.1 Remediação da fonte e fase retida, sem ocorrência de demais fases de contaminantes

Quando da ocorrência da fonte de contaminação na área, assim como da fase retida solo, é proposto que ocorra a remoção e destinação de ambas, uma vez que sua manutenção no sistema hidrogeológico local é fator que dificulta o sucesso do processo de recuperação do dano reversível. Apesar de representar um custo que o responsável legal da área usualmente quer evitar, a experiência demonstra que esta ação irá representar uma economia de tempo e investimento financeiro total no gerenciamento de área contaminada.

Tanto a remoção da remoção da fonte de contaminação (tanque ou linha de abastecimento) como o solo com fase retida podem ser facilmente cotado no mercado. Para tanto, para fins de estimativa do volume de solo com fase retida a remover, é proposto utilizar a premissa de cálculo da área da área da fase retida $\left(A F R, A F_{\text {cont }}\right.$ acrescidas de 2,0 m em suas laterais), até a profundidade do nível de água, tendo por mínimo a área de 42,25 $\mathrm{m}^{2}$ para cada $\mathrm{AF}_{\text {cont }}$ caracterizada. Para esta situação, devese considerar um prazo total de 4 (quatro) meses para a ação de remoção, sendo 3 (três) meses para a contratação e início da atividade e 1 (um) mês para a atividade em si.

Após a remoção da fonte e remediação do solo, para o caso do impacto não ter atingido a água subterrânea (ou apenas em baixas concentrações), deverá ocorrer o Monitoramento para o Encerramento (ME), realizado em um prazo de 21 (vinte e um) meses e, assim, estima-se um período total de 32 (trinta e dois) meses, conforme ilustra a Figura 6.4. 


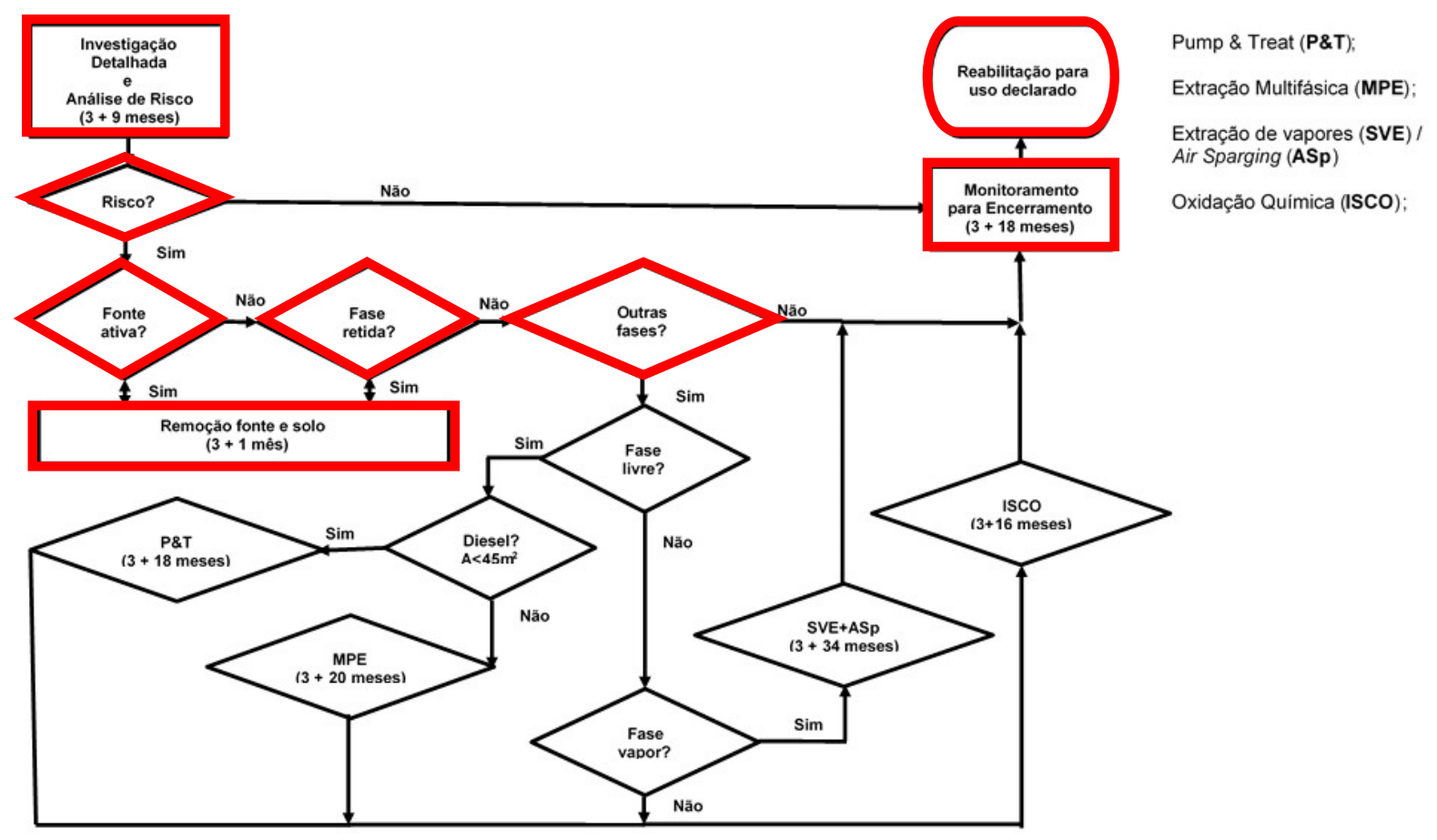

Figura 6.4 - Sequência de fluxo de decisão para a situação de apenas a ocorrência de fonte ativa e fase retida de contaminante no solo (destacado em vermelho).

6.2.2.2 Remediação da fase livre

6.2.2.2.1 Fase livre de diesel (combustível pesado) em pequena extensão $\left(<45,0 \mathrm{~m}^{2}\right)$

Para os casos de ocorrência de fase livre de combustíveis pesados, pouco volátil (diesel, óleo bpf, etc.), em que sua área de extensão caracterizada é menor que $<45,0 \mathrm{~m}^{2}$, a metodologia proposta considera que deve-se proceder sua remoção através da metodologia do Pump \& Treat (P\&T), pois sua pequena extensão de ocorrência usualmente não apresenta características de haver a necessidade de tratar a fase volátil, seja devido sua baixa volatilidade ou decorrente pouco tempo de residência no subsolo. 
Para a valoração do projeto, instalação e operação do sistema de remediação da fase livre, neste caso, deve-se cotar um sistema de P\&T considerando a instalação de 1 (um) poço de bombeamento e 1 (um) poço de injeção na área, considerando-se a profundidade do nível freático da área (caracterizada na Investigação Confirmatória) e uma distância padrão de 50 (cinquenta) metros para a instalação dos equipamentos superficiais de operação, tratamento e armazenamento de produto bombeados, bem como os de controle do sistema de remediação.

O sistema de remediação P\&T deverá operar, em média, durante 18 (dezoito) meses, fora os três meses necessários para a contratação, instalação e operação do sistema. Após a remediação da fase livre, deve-se proceder o tratamento da fase dissolvida pela metodologia da Oxidação Química (ISCO) por um período de 16 (dezesseis) meses, acrescidas dos 3 (três) meses necessários para a contratação do sistema, considerando a instalação de 3 (três) pontos de injeção para cada $150 \mathrm{~m}^{2}$ de área de fase dissolvida, executando até 4 (quatro) injeções de produtos oxidantes, uma a cada 3 (três) meses.

Posteriormente ao tratamento da fase dissolvida, dever-se-á proceder o Monitoramento para o Encerramento (ME) ao longo de 21 (vinte e um) meses, considerando a análise para os compostos PAH e BTEX em todos os poços de monitoramento estimados para a etapa de Investigação Detalhada (ID, além dos existentes, quando da execução da IC), perfazendo, assim, um período total meses 76 (setenta e seis) meses de remediação do dano reversível para o caso de presença de fase livre de combustível pesado e de fase dissolvida, sem a presença de fase vapor com necessidade de intervenção (Figura 6.5).

\subsection{Fase livre de combustíveis em grande extensão $\left(>45,0 \mathrm{~m}^{2}\right)$}

Já para os casos de ocorrência de fase livre de combustíveis, sejam eles leves ou pouco voláteis (diesel, óleo bpf, etc.), em que sua área de extensão caracterizada é maior que 45,0 $\mathrm{m}^{2}$, a metodologia proposta considera proceder sua remoção através da metodologia da Extração Multifásica (MPE), que irá atuar sobre a fase livre e a fase vapor simultaneamente. 


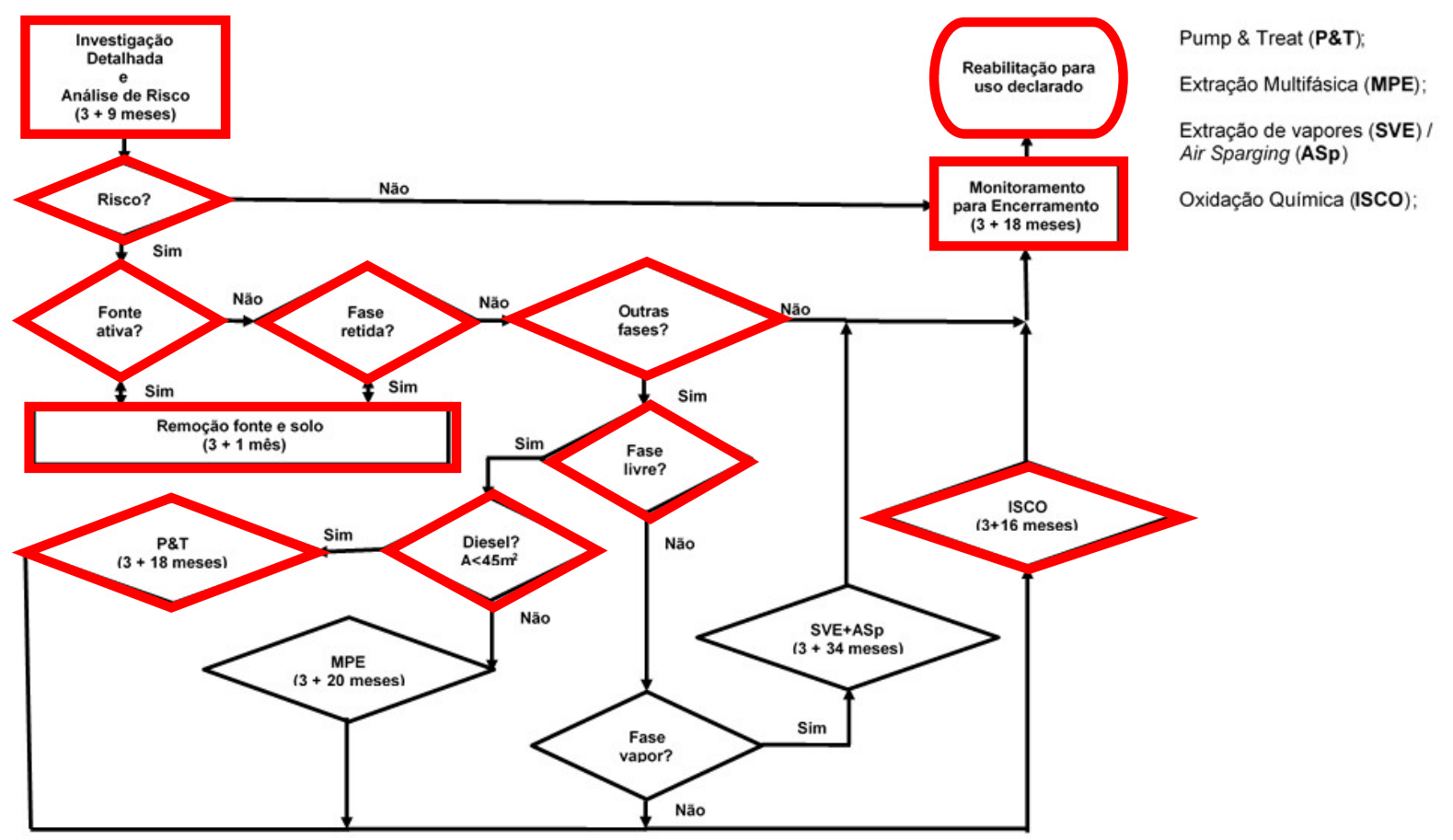

Figura 6.5 - Sequência de fluxo de remediação com ocorrência defase livre de diesel (combustível pouco volátil) em pequena extensão $\left(<45,0 \mathrm{~m}^{2}\right)$ (destacado em vermelho).

Para a valoração do projeto, instalação e operação do sistema de remediação da fase livre, neste caso, deve-se cotar um sistema de MPE considerando a instalação de 3 (três) poços de extração e 1 (um) de injeção a cada $150 \mathrm{~m}^{2}$ de ocorrência da fase dissolvida na área, considerando uma distância padrão de 50 (cinquenta) metros para a instalação dos equipamentos superficiais de operação, tratamento e armazenamento de produto bombeados, bem como os de controle do sistema de remediação.

O sistema de remediação MPE deverá operar, em média, durante 20 meses, fora os três meses necessários para a contratação, instalação e operação do sistema. Após a remediação da fase livre, assim como no item anterior, deve-se proceder o tratamento da fase dissolvida pela metodologia da Oxidação Química (ISCO) por um período de 16 (dezesseis) meses, acrescidas dos 3 (três) meses necessários para a contratação do sistema, considerando a instalação de 3 (três) pontos de injeção para cada $150 \mathrm{~m}^{2}$ de área de fase dissolvida, executando até 4 (quatro) injeções de produtos oxidantes a cada 3 (três) meses. 
Posteriormente ao tratamento da fase dissolvida, dever-se-á proceder o Monitoramento para o Encerramento (ME) ao longo de 21 (vinte e um) meses, considerando a análise para os compostos PAH e BTEX em todos os poços de monitoramento estimados para a etapa de ID (além dos existentes, quando da execução da Investigação Confirmatória), perfazendo, assim, um período total de 79 (setenta e nove) meses de remediação do dano reversível para o caso de presença de fase livre de combustível em área maior que $45,0 \mathrm{~m}^{2}$, sem a presença de fase vapor com necessidade de intervenção (Figura 6.6).

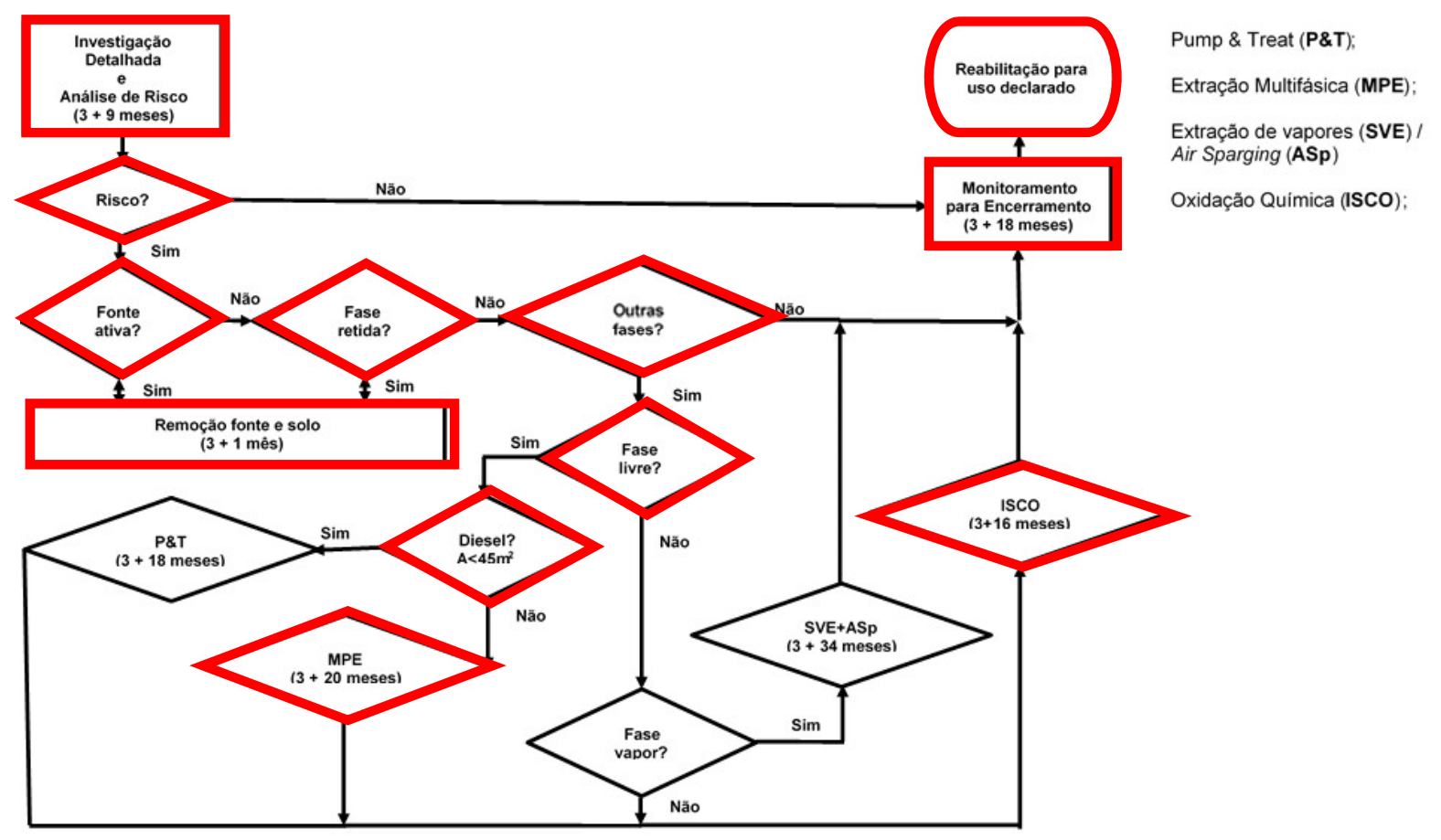

Figura 6.6 - Sequência de fluxo de remediação com ocorrência de fase livre em grande extensão $\left(>45,0 \mathrm{~m}^{2}\right)$ (destacado em vermelho).

6.2.2.3 Remediação da dissolvida com risco da fase vapor.

Para a situação em se caracteriza apenas a ocorrência da fase dissolvida na área, com estimativa qualitativa de risco da fase vapor, a processo de quantificação proposto considera a remediação do dano reversível pela metodologia combinada de remediação através da Extração de vapores (SVE) e Air Sparging (ASp), considerando o dimensionamento do sistema de 3 (três) poços de extração (SVE) e 1 (um) de injeção de ar (ASp) para cada $150 \mathrm{~m}^{2}$ de ocorrência da fase dissolvida.

Deve-se considerar que o Sistema SVE/ASp deverá ser operado ao longo de 34 (trinta e quatro) meses, fora os 3 (três) meses de contratação e projeto. 
Assim como nos sistemas anteriores, após o tratamento da fase dissolvida, dever-seá proceder o Monitoramento para o Encerramento (ME) ao longo de 21 (vinte e um) meses, considerando a análise para os compostos PAH e BTEX em todos os poços de monitoramento estimados para a etapa de ID (além dos existentes, quando da execução da IC), perfazendo, assim, um período total meses 74 (setenta e quatro) meses de remediação, conforme ilustra a Figura 6.7.

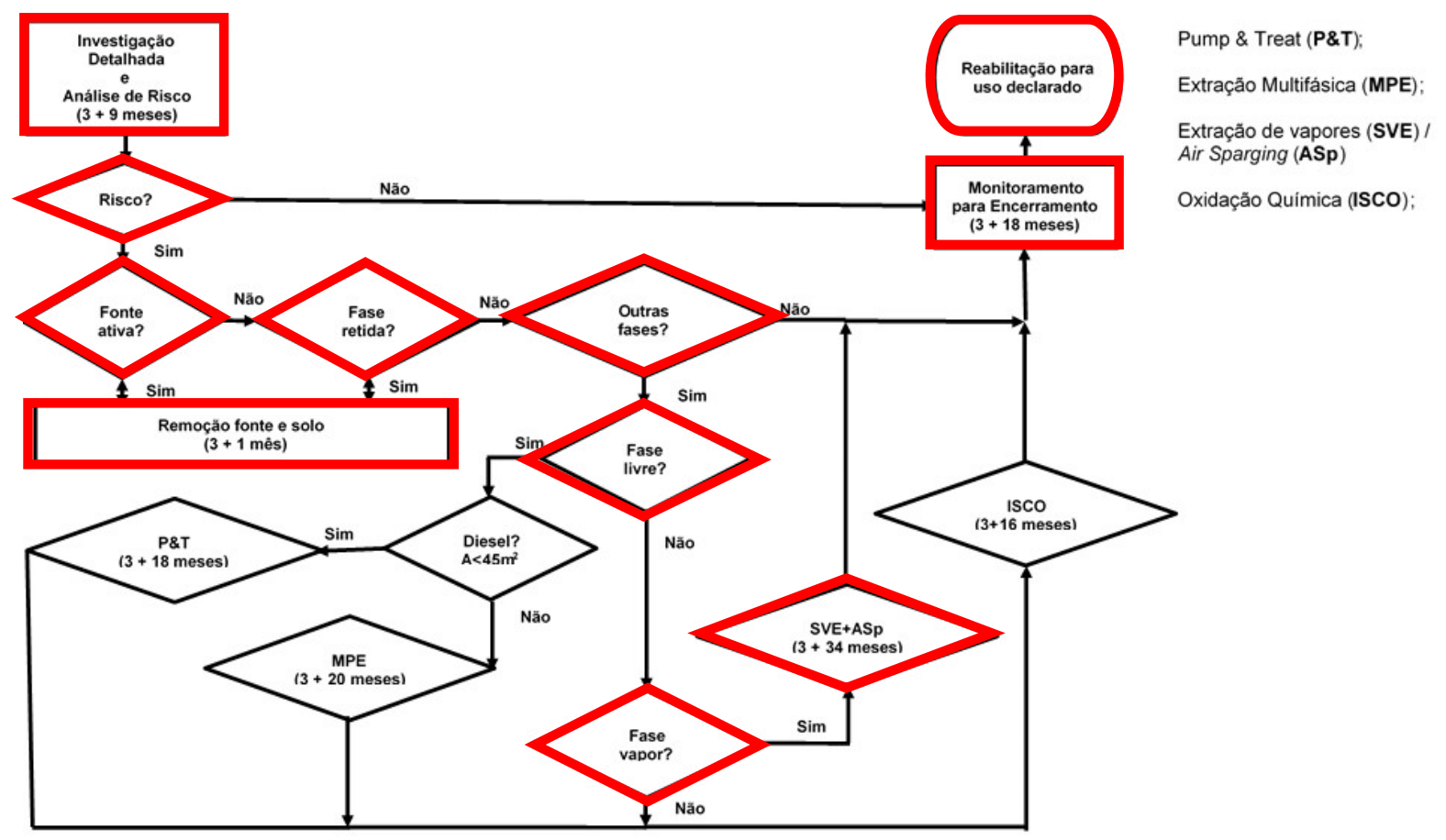

Figura 6.7 - Sequência de fluxo de remediação com ocorrência da fase dissolvida com risco da fase vapor (destacado em vermelho).

6.2.2.3 Remediação da fase dissolvida sem risco na fase vapor.

Para o caso de necessidade de remediação da fase dissolvida, sem que se estime a existência de risco associado a fase vapor, a metodologia de quantificação proposta considera que a remediação pela Oxidação Química (ISCO), por um período de 16 meses, acrescidas dos 3 (três) meses necessários para a contratação do sistema, considerando a instalação de 3 (três) pontos de injeção para cada $150 \mathrm{~m}^{2}$ de área de fase dissolvida, executando até 4 (quatro) injeções de produtos oxidantes, uma a cada 3 (três) meses. 
Considerando o tempo necessário para proceder o Monitoramento para o Encerramento (ME), estima-se um período total meses 56 (setenta e seis) meses de remediação do dano reversível, conforme ilustra a Figura 6.8.

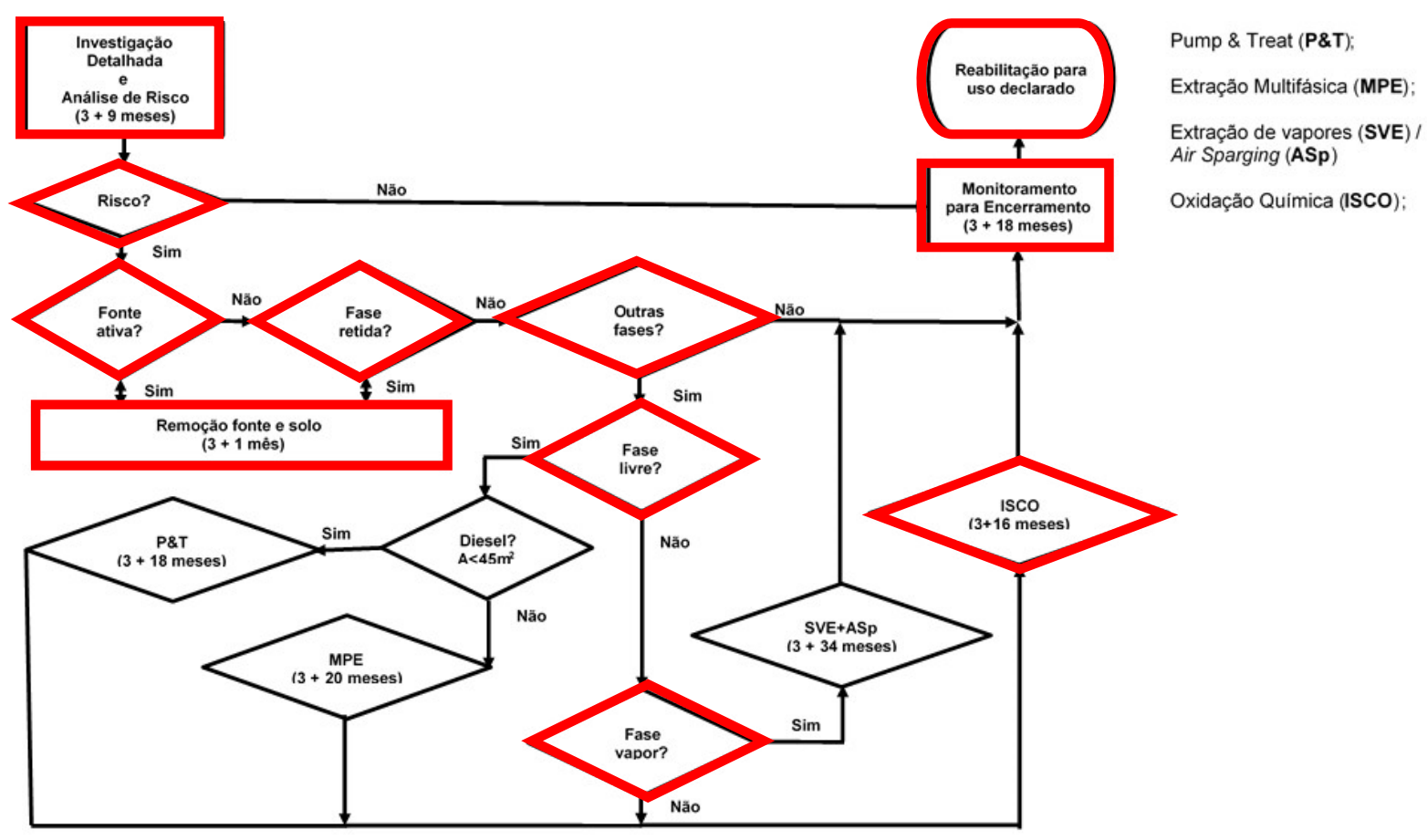

Figura 6.8 - Sequência de fluxo de remediação com a ocorrência da fase dissolvida sem risco da fase vapor (destacado em vermelho).

\subsubsection{Calibração e validação da quantificação das atividades de remediação}

Os dados apresentados no item 6.1.1 "Calibração e validação da quantificação das atividades de investigação", a metodologia proposta de Estimativa Baseada na Investigação Confirmatória (EBIC) indica os prazos e quantitativos de remediação em função do fluxograma de decisão. Considerando as ações de remediação estimadas, a partir dos dados básicos de Investigação Confirmatória simuladas, a planilha apresentou os quantitativos de remediação dos sistemas estimados que foram orçados conforme valores previamente contados no mercado (3 empresas de porte diferentes). 
Pra fins de ilustração, é apresentada, no Quadro 6.4 os resultados de um dos casos simulados, que indicou a necessidade de um investimento total médio de $R \$$ 1.305.222,59 (um milhão, trezentos e cinco mil, duzentos e vinte e dois reais e cinquenta e nove centavos) para efetuar a remediação do dano reversível ao longo de seis anos e meio, similar ao ocorrido na prática, para este caso. Como os demais casos simulados, apresentaram resultados coerentes ao verificados na prática, a planilha EBIC foi considerada calibrada e validada.

Quadro 6.4 - Investimento estimado para a remediação do dano reversível, conforme planilha EBIC

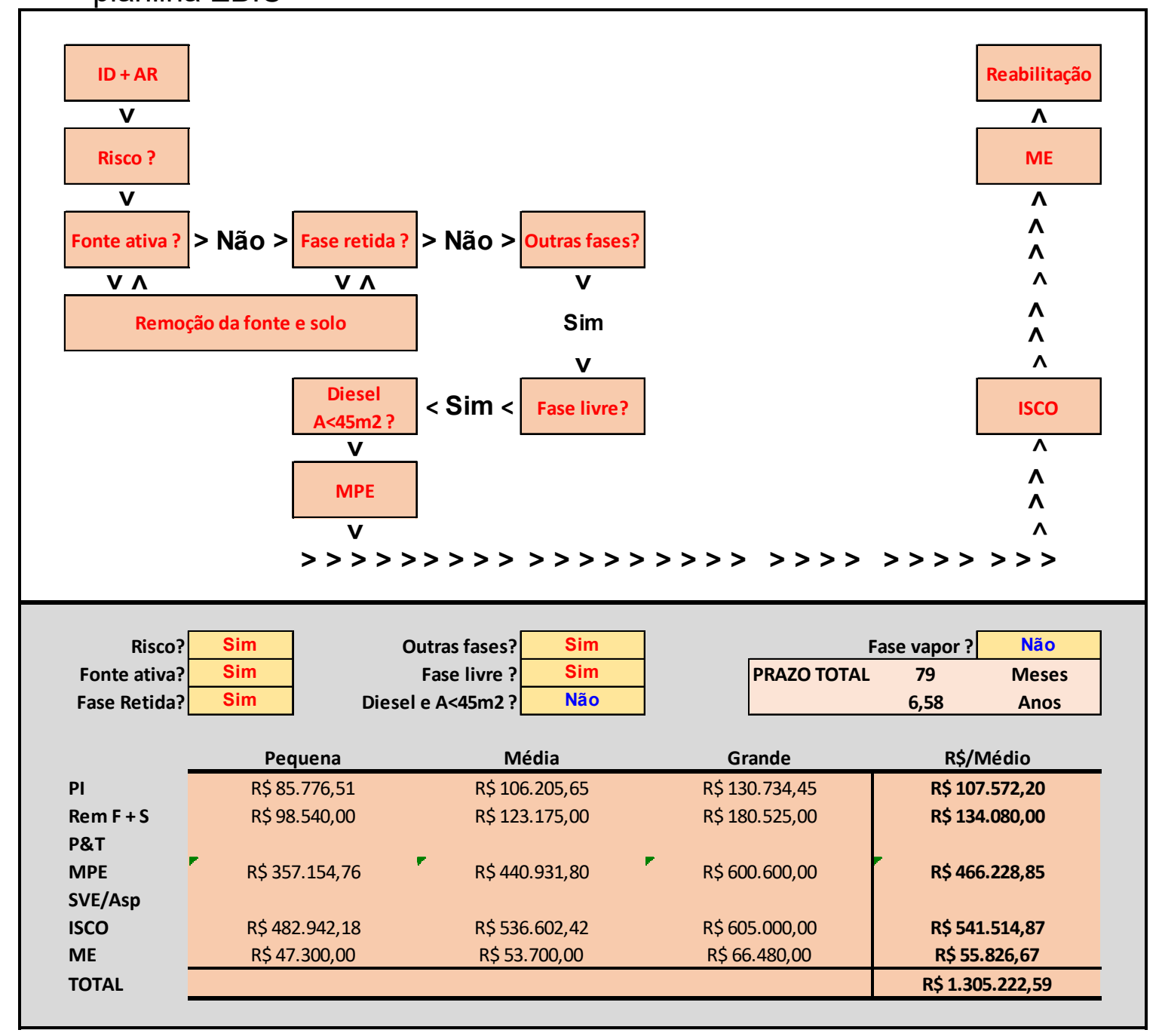




\section{CONTRIBUIÇÃO PARA A REPARAÇÃO DO DANO AMBIENTAL IRREVERSÍVEL}

Para a quantificação das ações de investigação e remediação do dano reversível, o autor dessa tese propõe uma metodologia de Estimativa Baseada na investigação Confirmatória, aqui denominada de EBIC, conforme descrito anteriormente.

Apesar de não ser o objetivo principal desta tese, quando ocorre a contaminação de uma área, durante e após a remediação do dano reversível, há o impacto negativo sobre o imóvel e os serviços ambientais, sejam eles os culturais, do solo ou hídricos, conforme ilustra a Figura 7.1. Assim, os mesmos devem ser considerados quando da estimativa da valoração dos danos ambientais decorrente de uma contaminação.

O valor de indenização poderá servir para indenizar a sociedade e colaborar com o financiamento da gestão das áreas contaminadas, e, assim, serem pagos ao Estado. Todos os valores devem ser calculados e serem pagos em parcelas mensais ao longo de um período máximo de 30 anos, efetuado de forma mensal enquanto permanecer o dano irreversível.

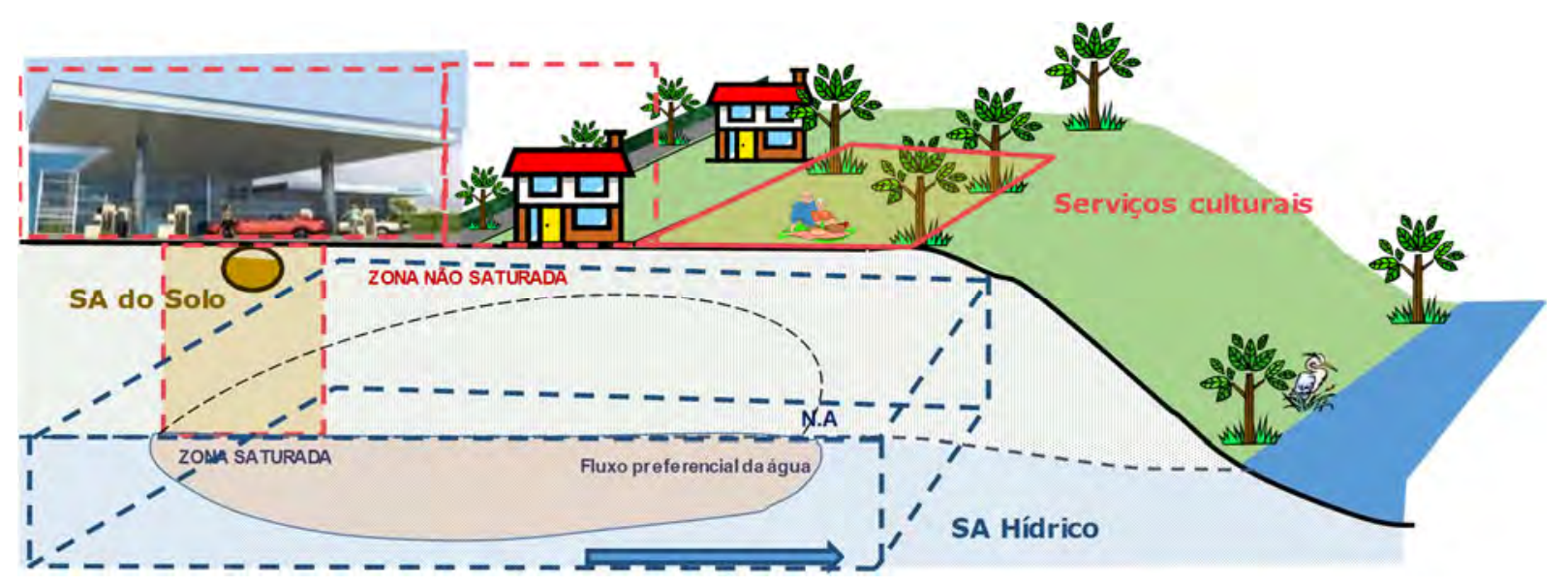

Figura 7.1 - llustração das áreas impactadas pelo contaminantes (SA = Serviço Ambiental).

\subsection{O IMPACTO DO DANO AMBIENTAL NO IMÓVEL}

O dano ambiental decorrente da existência de uma área contaminada será função do impacto da ocorrência nessa área, influenciando o uso do imóvel, podendo ocorrer em toda a extensão do imóvel ou de forma parcial. 
Poderão existir, em um terreno, uma ou mais Áreas Fontes de Contaminação ( $A F_{\text {cont }}$ ) caracterizadas que ocasionaram o impacto ambiental, afetando o uso do imóvel. A análise dos dados de áreas contaminadas por combustíveis fósseis indica que a contaminação na superfície do terreno e na zona não saturada (sua fase retida) ocorre apenas na área fonte e em seu entorno imediato (até 2,0 $\mathrm{m}$ de distância da $\mathrm{AF}_{\text {cont }}$ delimitada). Assim, usualmente o impacto da fase retida incide apenas sobre o imóvel no qual a $\mathrm{AF}_{\text {cont }}$ está localizada.

No entanto, quando o contaminante atinge a água subterrânea, este passa a ter uma dinâmica horizontal em concordância com o fluxo subterrâneo e, assim, passa a ter um potencial real de aumento da influência da área impactada, tanto pela ocorrência de fase livre, como da dissolvida ou de vapor. Após atingir a água subterrânea, a contaminação passa a apresentar um potencial de impacto em terrenos adjacentes à

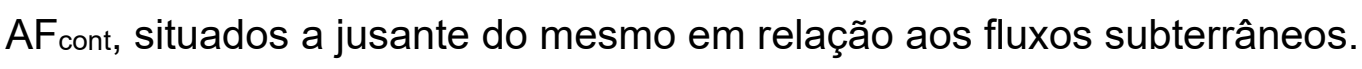

De forma conservadora, quando não for possível definir a extensão de seu impacto no uso do imóvel ou segregar seu impacto na área total, deve-se admitir, como premissa inicial, que o mesmo afeta a totalidade do imóvel, independentemente de sua extensão perante à área total do terreno.

A valoração antecipada do dano ambiental associada às áreas contaminadas deve contemplar o variação do valor do imóvel impactado (um ou mais) ocorrida entre o momento anterior posterior a contaminação, sua variação durante a existência da contaminação e depois da remediação do dano reversível, assim como, ao longo da alteração ambiental residual após a remediação, mesmo que esta não ofereça risco. Assim, na avaliação do dano ambiental, o autor dessa tese sugere que devam ser observados os seguintes aspectos:

a) Se o impacto da área contaminada ocorre em toda a área avaliada (ou ultrapassa seus limites e abrange mais de um imóvel), ou impacta apenas parcialmente o imóvel.

b) Se após a remediação do dano reversível, permanecerá uma dano irreversível, residual. 
c) Quando da conclusão da Investigação Confirmatória, apenas estarão caracterizados, entre outros aspectos, as características básicas do sistema hidrogeológico, a área da fonte e os contaminantes, não havendo a definição da extensão e dos riscos associados à contaminação, que somente é possível ser definida através das ações de Investigação Detalhada (ID) e Análise de Risco (ARtx), conforme definido nas NBR 15515-3 e 16209, respectivamente, e na Decisão de Diretoria 38 de fevereiro de 2017, pela CETESB.

O valor econômico do bem imóvel está associado ao valor de patrimônio e uso (seja efetivo ou potencial) que o imóvel pode prover, acrescido do valor de serviço ambiental, no momento inicial sem a contaminação, que pode variar ao longo do tempo devido a variação da demanda pelo mesmo.

O valor teórico de propriedade em si não varia com a ocorrência da contaminação, uma vez que ele é determinado pelo valor de mercado em função do seu entorno, pois o imóvel em si (terreno, estrutura, etc.) permanece e o que é afetado pelo dano ambiental é o seu uso, que passa a ser limitado devido à presença de contaminantes que oferecem riscos à saúde.

Quando ocorre a caracterização da contaminação, devido ao risco associado aos contaminantes, ocorre uma perda de valor associada ao uso e potencial de ganho do imóvel, visto que este passa a apresentar uma limitação de uso, assim como um passivo associado aos custos para o gerenciamento da área contaminada (GAC). Assim, o valor final do imóvel passa a variar, em relação à situação antes da contaminação, durante e após o dano reversível, conforme ilustra o Gráfico 7.1. A perda total de seu valor será proporcional ao risco associado à contaminação (e consequente limitação de uso do imóvel) e os custos associados a reparação do dano reversível. 


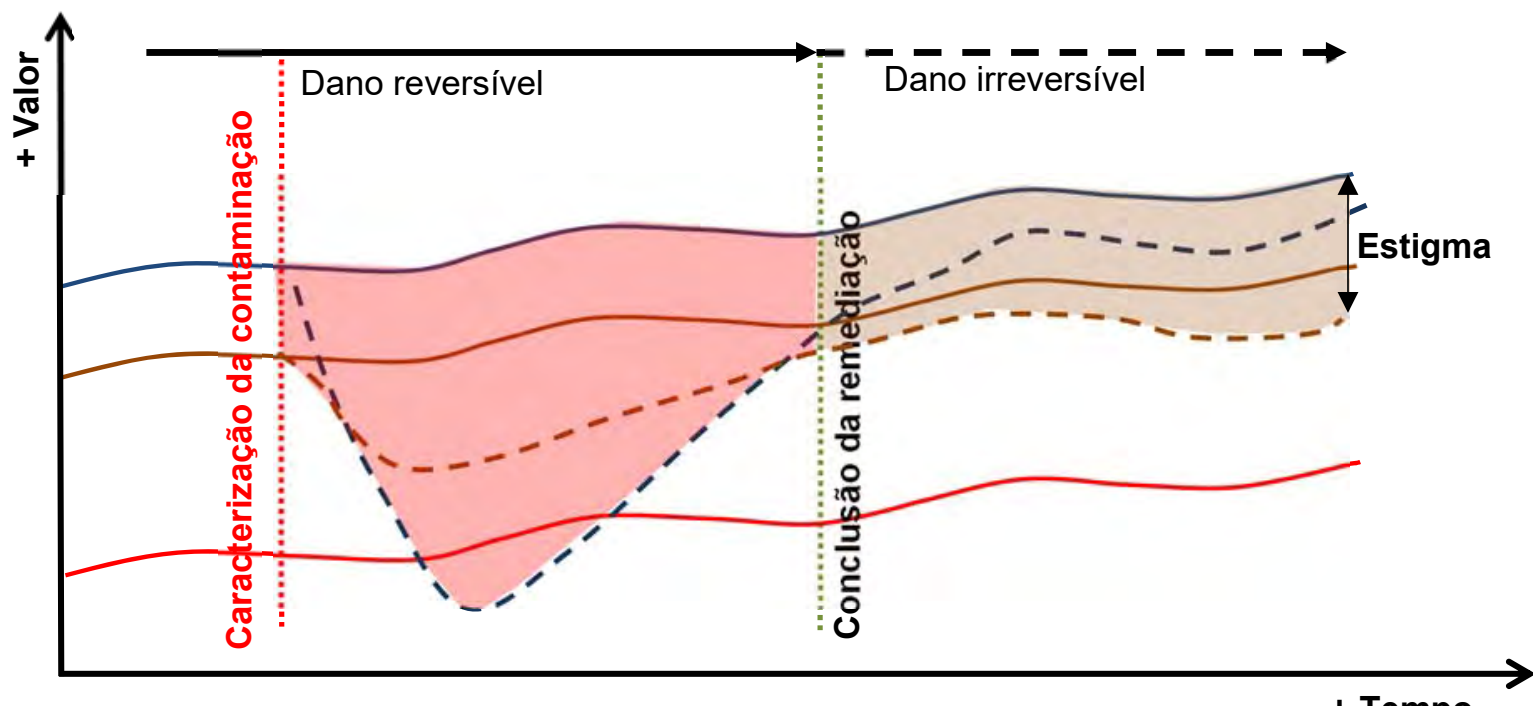

+ Tempo

— Valor de comercialização associado ao potencial de uso do imóvel

- - - . Valor de comercialização pós caracterização da contaminação

- Valor de usufruto

- - - . Valor de usufruto pós caracterização da contaminação

- Valor de propriedade

Gráfico 7.1 - Evolução do valor do imóvel frente à caracterização da contaminação do solo e/ou da água subterrânea.

O valor final do imóvel contaminado será representado pelo valor teórico do mesmo (valor de propriedade + uso + potencial de venda) subtraído dos gastos associados ao gerenciamento e à remediação da área contaminada, acrescido de um valor subjetivo associado a percepção do risco em relação aos contaminantes (estigma). Este valor pode ser, ao final, até negativo, podendo influenciar, assim, no interesse do proprietário em efetuar ou não o gerenciamento da área contaminada, se não for uma obrigatoriedade legal.

Com o início das ações de gerenciamento de área contaminada, ocorre uma recuperação dos valores associados ao usufruto e do potencial de ganho frente aos riscos associados aos contaminantes. Entretanto, a retomada dos patamares dos valores de usufruto e comercialização anteriores à contaminação da área dificilmente ocorre, permanecendo, enquanto haver uma percepção de risco da população para o uso da área, uma depreciação, o chamado estigma.

Cabe ressaltar que os objetivos de remediação com base no risco são estabelecidos considerando o uso pretendido, seja ele o atual ou futuro, e que, por sí só, limitam o potencial de uso do imóvel (já que a análise de risco que estabelece os objetivos da remediação não considera todos os usos possíveis). 
Um imóvel, uma vez tendo sido caracterizado como contaminado, sempre terá seu valor depreciado, a curto e médio prazos, em relação às áreas de seu entorno e de mesmas características, devido à limitação do uso associado e "preconceitos" subjetivos, o estigma. Este raciocínio não considera os custos do gerenciamento da área contaminada ou qualquer outro decorrente da existência da mesma.

Assim, entende-se que, como qualquer crime, além do responsável pela contaminação ter de promover a remediação do dano reversível, deve reparar o dano irreversível através de indenização financeira, já que, em teoria, sua remediação é inviável. Entretanto, considerando que no Brasil não existe pena perpétua para crimes, a reparação deve ser associado a um período limitado, seja pela recuperação natural das condições ambientais prévias ao dano (atenuação natural), ou, a semelhança do Art. 75 do Código Penal Brasileiro (CPB), ser de no máximo de 30 anos.

Considerando a diferenciação prevista no Art. 1225 do Código Civil (BRASIL, 2002), das figuras do nu-proprietário e do usufrutuário, bem como o valor do usufruto correspondente a 33\% do valor do imóvel, definido pelo Estado de São Paulo, o autor desta tese sugere que o valor da reparação do dano irreversível associado ao proprietário do imóvel deve ser, no máximo, equivalente a $1 / 3$ do valor do imóvel, percentual este de perda semelhante ao estigma associado as áreas contaminadas. Este valor, deve ser calculado a ser pago em parcelas mensais ao longo de 30 anos, efetuado de forma mensal enquanto permanecer o dano irreversível, até, no máximo, um período total de 30 anos.

Possíveis perdas e danos decorrente da limitação do uso do imóvel durante a investigação e remediação do dano reversível, assim como as caracterizadas para o período do dano irreversível, deverão ser pleiteadas conforme preconiza os artigos 402 a 407 da Lei n. 10.406 de 10 de janeiro de 2002, do Código Civil.

Considerando as figuras do nu-proprietário e do usufrutuário, bem como o valor do usufruto correspondente a $33 \%$ do valor do imóvel, ambos definidos na legislação do Estados de São Paulo, bem como o prazo de pena máxima de 30 anos previsto no Código Civil (BRASIL, 2002), o autor dessa tese propões que, no caso de necessidade de reparação do dano ambiental a proprietários de imóveis impactados, o valor máximo seja correspondente a $30 \%$ do valor antes da ocorrência da contaminação, a ser pago em parcelas ao longo de 30 anos. 
Assim, considerando o imóvel onde ocorreu, o valor do dano ambiental pode ser expresso, de forma simplificada, conforme proposto pela Equação 7.1.

$$
\$ D=\$ \operatorname{lnv}+\$ \operatorname{Rev}+(1 / 3 \$ \operatorname{lmov}) / 360 \text { * TDrev })+(1 / 3 \text { \$Imov) [Equação 7.1] }
$$

Onde:

$\$ D=$ Valor do dano ambiental $(R \$)$.

\$Inv = Valor da investigação da contaminação $(R \$)$.

\$Imov = Valor do imóvel sem a contaminação $(R \$)$.

$\$ R e v=$ Valor do reparação do dano reversível $(R \$)$.

TDrev = tempo necessário para reparação do dano reversível $\left(n^{\circ}\right.$ de meses).

\subsection{O IMPACTO DO DANO AMBIENTAL NOS SERVIÇOS AMBIENTAIS CULTURAIS}

A fase dissolvida (ou mesmo livre) poder migrar, em função dos fluxos subterrâneos, para terrenos adjacentes a $\mathrm{AF}_{\text {cont, }}$ podendo afetar o uso destes imóveis devido a presença da fase vapor, ou mesmo, impactos associados a drenagens superficiais. Pode ocorrer, ainda, impactos subjetivos quanto ao uso dos imóveis apenas pela presença confirmada de contaminação no "terreno vizinho", limitando o uso do mesmo. Entretanto, esta última hipótese é de difícil caracterização e, aqui, não é considerada.

Quando o impacto ocorre sobre imóveis privados, este deve ser avaliado a semelhança do impacto na área fonte. Entretanto, quando ocorre em áreas públicas, para fins desta tese, o autor entende como impacto aos serviços culturais e, assim, também, deve ser reparado. Sugerimos que a reparação deva ocorrer através de compensação ao responsável legal da área.

De forma simplificada e conservadora, é sugerido atribuir o mesmo valor teórico que o terreno da área fonte $\left(A F_{\text {cont }}\right)$, independente de seu uso. Assim, deve haver uma reparação financeira ao responsável legal da área no valor equivalente a 1/3 do valor do imóvel impactado, proporcional a área afetada ao longo do período de até 30 (trinta) anos. 


\subsection{O IMPACTO DO DANO AMBIENTAL NOS SERVIÇOS AMBIENTAIS DO SOLO}

O dano ambiental decorrente de área contaminada por combustíveis fósseis tende a afetar o solo (e os serviços ambientais associados), principalmente, na área fonte de contaminação ( $A F_{\text {cont }}$ ). Entretanto, a fase livre, por apresentar uma dinâmica horizontal associada ao fluxo de água subterrânea, apresenta o potencial de afetar diretamente os serviços ambientais do solo distante da área fonte, podendo originar uma fase retida devido a variação do nível freático.

Assim, para fins de reparação dos serviços ambientais do solo, de forma conservadora, recomenda-se que seja considerado o valor calculado para a compra e transporte para o local impactado do volume total de solo equivalente a zona não saturada da Área da Fase Retida (AFR) somada a área de ocorrência da fase livre (se existir), considerando, uma área total mínima de $42,25 \mathrm{~m}^{2}$.

\subsection{O IMPACTO DO DANO AMBIENTAL NOS SERVIÇOS AMBIENTAIS HÍDRICOS}

A fase dissolvida e livre poder migrar para terrenos adjacentes a $\mathrm{AF}_{\text {cont, }}$ impactando a água subterrânea e limitando seu uso ao longo de seu percurso.

A Constituição Federal brasileira (Art. 20, IX) determina que os recursos minerais constituem bens da União e, consequentemente, as águas subterrâneas pertencem ao Estado e o subsolo, ao proprietário do imóvel. Assim, a água subterrânea deve ser indenizada ao Estado. Entretanto, quando pessoas físicas e jurídicas detiverem a outorga de exploração das águas subterrâneas dentro da área impactada, este é o que deve ser compensado.

Para ambos os casos, deve ser adotada a metodologia de cálculo proposto por Bertolo (2019), de forma a indenizar a sociedade e colaborar com o financiamento da gestão dos recursos hídricos, para os serviços de provisão, regulação e suporte, dado pela Equação7.2.

$$
\mathrm{VA}=\mathrm{V}_{\text {cont }}{ }^{*} \mathrm{R} \$ \text { [Equação 7.2] }
$$

$\mathrm{VA}=$ Valor da Água (em $\mathrm{R} \$$ ).

$V_{\text {cont }}=$ Volume de água contaminada em um aquífero $\left(\mathrm{em} \mathrm{m}^{3}\right)$. 
$\mathrm{R} \$$ = Custo de substituição da água $\left(\mathrm{em} \mathrm{R} \$ / \mathrm{m}^{3}\right.$ ), tendo por referência o custo da água tratada na região.

Para o cálculo do volume de água deverá ser considerado a área potencial da fase dissolvida (AFD) e parâmetros físicos de armazenamento estimados em função da litologia predominante. 


\section{CONCLUSÃO E RECOMENDAČ̃̃O}

Destacam-se as seguintes conclusões ao trabalho:

a) As áreas contaminadas já representam sérios impactos negativos para a sociedade como um todo, tanto nos aspectos econômicos como social e ambiental. Sua compreensão e a real dimensão de seus impactos econômicos é fundamental para o seu gerenciamento. A não-visibilidade dos custos associados aos danos ambientais decorrente de áreas contaminadas resulta em uma menor preocupação (e negligência) geral dos empreendedores em relação ao tema.

b) A reparação do dano ambiental (área contaminada) deve ser incentivada e, para tanto, deve ser fomentada a utilização das áreas já degradadas (brownfields), apoiando e fornecendo proteção jurídica para empreendedores que desejem adquirir áreas contaminadas e efetuar sua investigação e remediação para posterior uso em conformidade aos aspectos legais.

c) É necessário ter prudência ao iniciar um processo de valoração do dano ambiental, tendo por base o "princípio da precaução".

d) Quando ocorre a execução da Investigação Detalhada (ID) e análise de Risco Toxicológico (ARtx) de área contaminadas por combustíveis fósseis, em 92,31 \% da vezes haverá a necessidade de remediação da mesma. As ações de Gerenciamento de Áreas Contaminadas (GAC) ocorrem, em média, ao longo de 6,5 anos (78 meses) área.

e) Existe uma baixa variação dos parâmetros hidrogeológicos das áreas contaminadas por combustíveis fósseis, independente do contexto geológico regional.

f) Em relação as atividades de investigação de áreas contaminadas por combustíveis fósseis, destaca-se:

$\checkmark$ a investigação da fase vapor dos contaminantes do tipo Soil Gas Survey (SGS) contribui com a qualidade do GAC e deve ser incentivada; 
existe uma baixa preocupação de investigação da fase retida de combustíveis fósseis no solo, contribuindo para o insucesso das ações de GAC. A fase retida ocorre, em média, de forma restrita, próxima da área fonte da contaminação (distâncias inferiores a 2,0 m da mesma);

$\checkmark$ a troca ou remoção do tanque de combustível é a técnica mais aplicada na eliminação da fonte de contaminação, ocorrendo em $64 \%$ dos casos estudados, sendo este, uma fator chave no processo de reabilitação da área.

g) A tecnologia de remediação mais aplicada na remediação de áreas contaminadas por combustíveis fósseis é a da Extração Multifásica (MPE), seguida pelo Pump \& Treat (P\&T) e da Extração de Vapores (SVE) com ventilação induzida - Air Sparging (ASp).

h) Considerando a eficiência e eficácia na diminuição da massa dos contaminantes, as seguintes técnicas de remediação do dano reversível destacam-se:

$\checkmark$ utilização remoção e destinação do solo para a remediação da fase retida;

$\checkmark$ a técnica do P\&T para remoção da fase livre sem vapor (com risco) associado, com ocorrência em área menor que $20 \mathrm{~m}^{2}$;

$\checkmark$ utilização da MPE para a remediação da fase livre com risco da fase vapor associado, secundariamente atuando nas fases retidas e dissolvida;

$\checkmark$ aplicação do SVE/ASp para a remediação da fase dissolvida e, secundariamente, da fase vapor;

$\checkmark$ Utilização da Oxidação Química (ISCO) para a remediação da fase dissolvida sem fase vapor.

i) Com base nos dados médios obtidos em centenas de trabalhos de GAC é proposta uma metodologia de Estimativa Baseada na Investigação Confirmatória - EBIC, que estima as atividades e prazos médios necessários para a investigação e remediação do dano reversível, subsidiando a cotação das mesmas no mercado, de forma a possibilitar sua valoração antecipada.

j) A metodologia EBIC proposta apresentou boa representatividade de seus prognósticos em relação aos prazos e quantificação das atividades de GAC, quando comparada a casos reais. 
k) O dano irreversível (que permanece após as ações de remediação e reabilitação da área) afeta o uso do imóvel e os Serviços Ambientais (SA) e, consequentemente, deve ser considerado na valoração antecipada do dano ambiental como um todo.

I) A desvalorização máxima do imóvel ocorre quando da contaminação e sua caracterização, havendo um decréscimo da mesma ao longo das ações de GAC até a reabilitação da área.

Entretanto, o valor nunca tende a voltar ao valor original, permanecendo uma desvalorização em torno de $30 \%$ em relação ao valor antes da contaminação, com caráter subjetivo associado a uma percepção de risco ambiental da população, denominado de estigma, semelhante ao percentual atribuído ao nu- proprietário em relação ao valor total do imóvel (sem contaminação).

As seguintes recomendações são apresentadas:

a) de forma a obter uma boa estimativa dos custos médios de execução das atividades estimadas pela metodologia EBIC, sejam efetuados orçamentos com, no mínimo, 3 (três) empresas de consultoria distintas, de preferência com porte de atuação diferentes (atuação internacional, nacional e local).

b) que seja desenvolvido e disponibilizado uma plataforma digital de dados de acesso público que possibilite a inserção direta das informações e documentos associados a área contaminada investigada, diretamente no banco de dados da Companhia Ambiental de São Paulo - CETESB, com responsabilidade associada através de certificados de assinatura digital reconhecidos.

O banco de dados deve ser de fácil acesso ao público em geral pela internet, em níveis de responsabilidades legais, em formatos digitais facilmente manipulados pelos técnicos e pesquisadores (planilhas, mapas vetorizados georreferenciados, etc.).

c) Caso ocorra necessidade de reparação aos proprietários de imóveis impactados, recomenda-se a utilização de um valor de referência máximo de:

$\checkmark$ um valor total correspondente a $30 \%$ do valor do imóvel, antes da ocorrência da contaminação, pago ao longo do processo de GAC até sua reabilitação em relação ao dano reversível; 
$\checkmark$ um valor máximo correspondente a $30 \%$ do valor do imóvel antes da ocorrência da contaminação, a ser pago em parcelas 360 parcelas mensais enquanto persistir o dano, representando um período máximo de 30 anos. caso ocorra a necessidade de reparação do dano ambiental irreversível a proprietários de imóveis impactados, após a reabilitação da área;

possíveis perdas e danos decorrente de uma limitação do uso do imóvel, deverá ser discutida conforme preconiza os artigos 402 a 407 da Lei $n$. 10.406 de 10 de janeiro de 2002, do Código Civil.

d) Caso ocorra necessidade de reparação dos Serviços Ambientais, recomendase a utilização dos seguintes valores de referência:

$\checkmark$ para os serviços ambientais do solo, um valor máximo equivalente aos custos para remoção e reposição do solo equivalente ao volume estimado da fase retida;

$\checkmark$ para os serviços ambientais hídricos, um valor máximo equivalente ao volume total de água impactada, calculada considerando-se o período do dano irreversível, tendo por base o valor de água bruta ou potável (a depender do caso do uso considerado), em vigor na região.

\subsection{LIMITAÇÕES DA METODOLOGIA PROPOSTA}

Devem ser observadas as seguintes limitações a metodologia de Estimativa Baseada na Investigação Confirmatória (EBIC), proposta nesta tese de doutorado:

a) A metodologia $\mathrm{EBIC}$ foi desenvolvida para uso pelo responsável legal para fins de planejamento financeiro, não apresentando respaldo legal para o atendimento de quaisquer aspectos legais associados ao tema e não substitui a necessidade dos trabalhos de um profissional técnico responsável.

b) As estimativas EBIC são baseadas em análises estatísticas efetuadas nesta pesquisa de doutorado, e efetua os cálculos, de forma conservadora, baseado nas informações obtidas nas etapas inicias de GAC (Avaliação Preliminar - AP e Investigação Confirmatória - IC). 
Assim, a qualidade das informações contidas na AP e IC (ou ausência), influenciará, e muito, nas incertezas e, consequentemente, nos resultados das quantificações e valorações associadas para a investigação e remediação do dano reversível.

c) As estimativas apresentadas pela metodologia EBIC podem ser alterados em função do desenvolvimento das ações de GAC subsequentes, sob responsabilidade técnica de profissional devidamente qualificado.

d) As técnicas de investigação e remediação do dano ambiental reversível associados as áreas contaminadas por combustíveis fósseis está em constante desenvolvimento e melhoria. Assim, a aplicação da metodologia EBIC deve ser constantemente atualizada e calibrada, promovendo um desenvolvimento e melhoria contínua ao longo do tempo, através de uma constante inserção de dados representativos das diversas etapas de GAC e em função das informações técnicas do mercado. 


\section{BIBLIOGRAFIA}

AGÊNCIA NACIONAL DE PETRÓLEO (2015). Mercado Nacional de Combustíveis. Disponível em: www.anp.gov.br/wwwanp/?dw=79687. Acesso em: 30 de maio 2017.

ALCAMO, J.; DÖLL, P.; HENRICHS, T., KASPAR, F.; LEHNER, B.; RÖSCH, T.; SIEBERT, S. (2003). Development and testing of the Water. GAP 2 global model of water use and availability. Hydrological Sciences, 48(3), pp. 317-337.

AMICCI, A. G. N. (2010). O impacto da resolução CONAMA 273/00 na gestão das áreas contaminadas por postos de combustíveis do Estado de São Paulo. Internunidades em Ciência Ambiental da Universidade de São Paulo, Programa de Pós-Graduação em Ciência Ambiental (PROCAM). Dissertação de Mestrado. São Paulo/SP.

ANDRADE, D. C. (2010). Modelagem e valoração de serviços ecossistêmicos: uma contribuição da economia ecológica. Campinas - Unicamp, (Tese de Doutorado).

ANTAI, I (2003) - Valuation Of Contaminated Land in Sweden: A Comparative

Study. Department of Infrastructure Division of Building and Real Estate Economics, Royal Institute of Technology, KTH, Stockholm. 67P.

ASSOCIAÇÃO BRASILEIRA DE NORMAS TÉCNICAS, NBR 14653-2 (2004). Avaliação de bens, imóveis urbanos. p. 16.

ASSOCIAÇÃO BRASILEIRA DE NORMAS TÉCNICAS, NBR 14653-6 (2008).

Recursos naturais e ambientais. p. 16.

ASSOCIAÇÃO BRASILEIRA DE NORMAS TÉCNICAS, NBR 16209 (2013) Avaliação de risco a saúde humana para fins de gerenciamento de áreas contaminadas.

ASSOCIAÇÃO BRASILEIRA DE NORMAS TÉCNICAS, NBR15515-3 (2013) Avaliação de passivo ambiental em solo e água subterrânea - Parte 3: Investigação detalhada. 
BARBISAN, A.O.; KALIL, R.L.;PANDOLFO, A.; LUBLO, R.; PANDOLFO,L.M; BRANDLI, E.N; MARTINS, M.S. (2007) - Aplicação da técnica de valoração econômica de ações de requalificação do meio ambiente em área degrada. R. RA'E GA, Curitiba, n. 14, p. 129-147, 2007. Editora UFPR

BERTOLO, R. A.; HIRATA, R. ; ALY JUNIOR, O. (2019) - Método de Valoração da Água Subterrânea Impactada por Atividades Contaminantes no Estado de São Paulo. Ver. Águas Subterrâneas, v. 33, n. 3, p. 303-313.

BRASIL (1981). Lei nº 6.938 - Dispõe sobre a Política Nacional do Meio Ambiente, seus fins e mecanismos de formulação e aplicação, e dá outras providências. Promulgada em 31 de Agosto de 1981. Disponível em http://www.planalto.gov.br/ccivil 03/leis/L6938.htm. Acesso em: 04 de maio 2018.

BRASIL. (1988). Constituição Federal de 1988. Promulgada em 5 de outubro de 1988.

Disponível em http://www.planalto.gov.br/ccivil 03/ constituicao/constituição.htm. Acesso em: 04 de maio 2018.

BRASIL (1998). Lei $n^{\circ} 9.605$ - Dispõe sobre as sanções penais e administrativas derivadas de condutas e atividades lesivas ao meio ambiente, e dá outras providências. Promulgada em 12 de Fevereiro de 1998. Disponível em http://www.planalto.gov.br/ccivil 03/ leis/19605.htm. Acesso em: 04 de maio 2018.

BRASIL (2002). Lei $\mathrm{n}^{\circ} 10.406$ - Código Civil.. Disponível em http://www.planalto.gov.br/ccivil 03/leis/2002/L10406compilada.htm. Acesso em: 27 de novembro de 2018.

BRASIL (2008). DECRETO Nº 6.514 - Dispõe sobre as infrações e sanções administrativas ao meio ambiente, estabelece o processo administrativo federal para apuração destas infrações, e dá outras providências. Promulgada em 22 de Julho de 2008. Disponível em http://www.planalto.gov.br/ccivil 03/ ato20072010/2008/decreto/ d6514.htm. Acessoem: 04 de maio 2018.

BROWN, R. (1994).- Treatment of Petroleum Hidrocarbons in Ground Water by Air Sparging - In Handbook of Bioremediation. pp: $61-85$. 
CALVET-MIR, L.; GÓMEZ-BAGGETHUN, E.; REYES-GARCÍA, V. (2012) - Beyond food production: ecosystem services provid by home gardens. A case study in VallFosca, Catalan Pyrenees, northeastern Spain. Ecological economics, v.74, p.153-160.

COHEN, R.M.; MERCER, J.W.; GREENWALD, R.M.; BELJIN, M;S; (1997) - Pumpand-Treat Systems. Ground Water Issue. Design Guidelines for Conventional. U.S.EPA - United State Environmental Protection Agency.

COMPANHIA AMBIENTAL DO ESTADO DE SÃO PAULO - CETESB (2001). Manual de gerenciamento de áreas contaminadas. Disponível em: http://www.cetesb.sp.gov.br/areas-contaminadas/manual-de-gerenciamento-deACs/7-manual, Acesso em: 30 de janeiro de 2017.

COMPANHIA AMBIENTAL DO ESTADO DE SÃO PAULO - CETESB (2007). Decisão de Diretoria No 103/2007/C/E, de 22 de junho de 2007 - Dispõe sobre o procedimento para gerenciamento de áreas contaminadas. São Paulo/SP, p. 40.

COMPANHIA AMBIENTAL DO ESTADO DE SÃO PAULO - CETESB (2013). Planilha de avaliação de risco de área contaminada sob investigação. Disponível em: https://cetesb.sp.gov.br/areas-contaminadas/planilhas-para-avaliacao/. Acesso em: 11de dezembro de 2018.

COMPANHIA AMBIENTAL DO ESTADO DE SÃO PAULO - CETESB (2017). Decisão de Diretoria Nº38/2017/C, de 07 Fevereiro de 2017 - Dispõe sobre a aprovação do "Procedimento para a Proteção da Qualidade do Solo e das Águas Subterrâneas", da revisão do "Procedimento para o Gerenciamento de Áreas Contaminadas" e estabelece "Diretrizes para Gerenciamento de Áreas Contaminadas no Âmbito do Licenciamento Ambiental”, em função da publicação da Lei Estadual $n^{\circ} 13.577 / 2009$ e seu Regulamento, aprovado por meio do Decreto $n^{\circ}$ 59.263/2013, e dá outras providências. Disponível em: http://www.cetesb.sp.gov.br/wp-content/uploads/2014/12/DD-038-2017-C.pdf. Acesso em: 07 de maio de 2018.

COMPANHIA AMBIENTAL DO ESTADO DE SÃO PAULO - CETESB (2018). Relação de áreas contaminadas e reabilitadas no Estado de São Paulo. Disponível em: http://areascontaminadas.cetesb.sp.gov.brl. Acesso em: 16 dedezembro de 2018. 
COMPANHIA AMBIENTAL DO ESTADO DE SÃO PAULO - CETESB (2019). Relação de áreas contaminadas e reabilitadas no Estado de São Paulo. Disponível em: https://cetesb.sp.gov.br/areas-contaminadas/wp-

content/uploads/sites/17/2018/01/Texto-explicativo.pdf, Acesso em: 6 dejaneiro de 2021.

CONFEDERAÇÃO NACIONAL DA INDÚSTRIA - CNI (2014). Perfil da Indústria nos Estados. Brasília - DF, p. 214.

CONSELHO NACIONAL DO MEIO AMBIENTE - CONAMA (2000). Resolução CONAMA n ${ }^{\circ} 273$, de 29 de novembro de 2000 - Estabelece diretrizes para o licenciamento ambiental de postos de combustíveis e serviços e dispõe sobre a prevenção e controle da poluição. Disponível em: https://cetesb.sp.gov.br/licenciamento/documentos/2000 Res CONAMA 273.pd f. Acesso em: 16 de dezembro de 2018.

CONSELHO NACIONAL DO MEIO AMBIENTE - CONAMA (2009). Resolução CONAMA n ${ }^{\circ} 420$, de 28 de dezembro de 2009 - Dispõe sobre critérios e valores orientadores de qualidade do solo quanto à presença de substâncias químicas e estabelece diretrizes para o gerenciamento ambiental de áreas contaminadas por essas substâncias em decorrência de atividades antrópicas. Brasília/DF. Disponível em: http://www.mma.gov.br/port/conama/legiabre.cfm?codlegi=620. Acesso em: 07 de maio de 2018.

CORREIA, M.E.F. (2002) - Relação entre diversidade da fauna de solo e o processo de decomposição e seus reflexos sobre a estabilidade dos ecossistemas. Seropédica: Embrapa agrobiologia, dezembro de 2002. 33p., Documento 156.

COSTANZA, R.; D'ARGE, R.; GROOT, R.; FARBERK, S.; GRASSO. M.; HANNON, B.; LIMBURG, K.; NAEEM, S.; O'NEILL. R.; PARUELO, J.; RASKIN, R. G.; SUTTONKK, P. \& DEN BELT, M.V..(1997)- The value of the world's ecosystem services and natural capital. Revista Nature, Vol. 387 de 15 May de 1997.

CONSTANZA, R (2000) - Social goals and valuation of ecosystem services. Ecosystems, v.3, n.1, p. 4-10.

CONSTANZA, R (2014) - Changes in the global value of ecosystem services. Global environmentalchange, v.26, p. 152-158. 
DANTAS, R. A. (2003) - Engenharia de Avaliações: uma introdução à metodologia científica. 1. ${ }^{a}$ Ed. São Paulo/SP.

DE GROOT, R.; WILSON, M. A.; BOUMANS, R. M. J. (2002) - A typology for the classification, description and valuation of ecosystem functions, goods and services. Ecological Economics 41. p. 393-408.

DYMINSKI, A.S. (2006) - Contaminação de solos e águas subterrâneas. Curitiba: Centro de Estudos de Engenharia Civil - CESEC, 2006. Disponível em: http://www.cesec.ufpr.br/docente/andrea/TC019 Contaminacao de solos.pdf. Acesso em: 16 agosto 2018.

EDSON SANTOS, E.; UNGARI, H.C.N., SANTOS, M.B (2008) - Principais técnicas de remediação e gerenciamento de áreas contaminadas por hidrocarbonetos no Estado de São Paulo. Monografia Curso de Especialização de Gestão Ambiental da Faculdade de Engenharia Mecânica da Universidade Estadual de Campinas UNICAMP.

FATORELLI. (2005) - Proposta de avaliação de risco ecológico para contaminações de petróleo e derivados: estudo de caso, 2005. Dissertação de Mestrado em Engenharia Ambiental - Univ. Fed. de Santa Catarina, Florianópolis, 2005.

FERREIRA, S. B. (2000) - Estudos laboratoriais para avaliação do potencial de contaminação de água e do solo por gasolina oxigenada. Tese (Doutorado Geotecnia) - Escola de Engenharia de São Carlos, Universidade de São Paulo, São Carlos.

FETTER, C. W. (1993). Contaminant Hydrogeology. Macmillan Publishing Company, U.S. $458 p$.

FINCO, M. V. A. (2004). Valoração Econômica de Zonas Costeiras: O Método de Valoração Contingente Aplicado ao Litoral do Rio Grande do Sul. Dissertação de mestrado, UFRGS, Rio Grande do Sul/RS.

FIDALGO, E. C.C; PRADO, R.B.; TURETTA, A.P.D; SCHULER, A. E. (2017) - Manual para Pagamento por Serviços Ambientais Hídricos. Seleção de áreas e monitoramento. Editoras técnicas, Embrapa, Brasília/DF. 
FONSECA, R.A.; LIMA, A.B.; REZENDE; J.L.P. (2013) - Métodos de valoração dos bens de serviços ambientais: uma contribuição para o desenvolvimento regional sustentável. $4^{\circ}$ Cong. Int. Governo, Gestão e Profissionalização em âmbito local frente aos desafios de nosso tempo, Rio de Janeiro/RJ.

GALLI, F. (1996). Valoração de danos ambientais: subsídio para ação civil. Série Divulgação e Informação, 193, Companhia Energética de São Paulo, CESP, São Paulo/SP.

HERBERT, B. P. (2011). Estudo da valoração monetária de propriedades contaminadas em ambiente urbano. Dissertação (Mestrado Profissionalizante Meio Ambiente Urbano e Industrial) - Universidade Federal do Paraná, Curitiba.

INSTITUTO BRASILEIRO DE MEIO AMBIENTE - IBAMA (2002) - Modelo de valoração econômica dos impactos ambientais em unidades de conservação. Instituto Brasileiro do Meio Ambiente e de Recursos Renováveis - Peixoto, W. G,Brasília, DF.

ICLEI-Brasil (2013) - Manual: Revitalização de áreas degradadas e contaminadas (brownfields) na América Latina. Departamento de Proteção Ambiental da Cidade de Stuttgart, Alemanha. $1^{\circ}$ ed. São Paulo, 2013.

INSTITUTO DE PESQUISA TECNOLÓGICAS DO ESTADO DE SÃO PAULO - IPT (2018) - A produção imobiliária e a reabilitação de áreas degradas: contratação de serviços, responsabilidades legais e viabilidade de empreendimentos. IPT/SECOVI, São Paulo/SP, 122p.

JARDIM, W.F.; CANELA, M.C. (2004) - Fundamentos da oxidação química no tratamento de efluentes e remediação de solos. Campinas, 2004. (Caderno temático, 1). Disponível em: <lqa.iqm.unicamp.br/cadernos/caderno1.pdf>. Acesso em: 24 maio 2012.

LAGREGA, M. D.; BUCKINGHAM, P. L.; EVANS, J. C. (1994) Hazardouswaste management. McGraw-Hill,. 1146p

LUSVARGHI NeTO, L.H.; Pedro PESSOA DIB, P.; MANCUSO, M.A. (2009) Avaliação de sistema de remediação do tipo pumpandtreat com o uso de MGO (modular groundwateroptimizer) - aplicação no caso do aterro de Volta Grande em Volta Redonda - RJ. I Cong. Int. de Meio Ambiente Subterrâneo, São Paulo. 
MACHADO, P.A.L (2009) - Direito Ambiental Brasileiro. 17 ed. São Paulo: Malheiros, 2009.

MACKAY, D.M. \& CHERRY, J.A. (1989) - Groundwater Contamination: Pump - and Treat Remediation, Environ. Sci. \&Technol., 23(6): 630 -636,1989.

MAIA, A.G. (2002) - Valoração de recursos ambientais. Dissertação de mestrado, Inst. De Economia, UNICAMP, Campinas.

MAIA, A. G, ROMEIRO, A. R;REYDON, B. P. (2004) - Valoração de recursos ambientais - metodologias e recomendações. Campinas: Unicamp. Instituto de Economia, mar. 2004. 38 p. (Texto para Discussão, n.116).

MAYNARD, S.; JAMES, D.; DAVIDSON, A. (2014) - Determining the value of multiple ecosystem services in terms of community wellbeing: who should be the valuing agent? Ecologicoleconomics.

MARCELINO, A.; HADDAD, E.; AVENTURATO, H.; CAMPOS, M. V.; SERPA, R. R. (1992) - Proposta de critério para valoração monetária de danos causados por derrames de petróleo ou de seus derivados no ambiente marinho, CETESB, São Paulo, $22 \mathrm{p}$.

MARCELINO, B.M (2016) - Gerenciamento de áreas contaminadas. Apresentação na Ass. Internacional de Direito de Seguros AIDA/BRASIL, p. 19.

MARKER, A. (2013) - Manual: Revitalização de áreas degradadas e contaminadas (brownfields) na América Latina. ICLEI-Brasil Departamento de Proteção Ambiental da Cidade de Stuttgart, Alemanha, $1^{\circ}$ ed. São Paulo.

MENDESONHN, R.; OLMNSTEAD, S.(2009) - The Economic valuation of environmental amenities and disamenities: methods and apllicationsannu. Rev. Environresource, v.34, p $325-347$.

MICCI, A.G.N. (2010). O impacto da resolução CONAMA 273/00 na gestão das áreas contaminadas por postos de combustíveis do Estado de São Paulo. Dissertação de mestrado, Programa de Pós Graduação em Ciência Ambiental (PROCAM), Universidade de São Paulo, São Paulo, 111 p. 
MICHAEL, R. (2004) - Avaliação em Massa de Imóveis com Uso de Inferência Estatística e Análise de Superfície de Tendência. Dissertação (Mestrado em Engenharia Civil) - Programa de Pós Graduação em Engenharia Civil, UFSC, Florianópolis/SC.

MILARÉ, E. (2001) - Direito do Ambiente. Doutrina - prática - jurisprudência glossário. 2. ed. rev., ampliada e atualizada. São Paulo/SP. p. 427 e 428.

MILARÉ, E. (2007) - Direito do Ambiente: doutrina, jurisprudência, glossário. 05 ed. São Paulo: Editora Revista dos Tribunais.

MILLENNIUN ECOSSYSTEM ASSESSMENT - MEA (2003) - Ecosystems and human well-being. Wshingon, DC. Islandpress.

MINISTÉRIO PÚBLICO DE SÃO PAULO - MPSP (2014) -Relatório Final de Grupo de Trabalho de Valoração do Dano Ambiental - ATO PGJ 45/2012. Relatório Final do Subgrupo VI: Áreas Contaminadas, p105 a 119.

MOERI, E.; COELHO, R.; MARKER, A. (2004) - Remediação e revitalização de áreas contaminadas. São Paulo, Signus Editora.

MONZONI, M; BRANCO, P; ARMELIN, R; SOUZA, R; MAGALHÃES, G.; LUTTI, N.; ARMELIN, R.; MARA ALVES; L. M.; INHETVIN, T.; LISBONA, P.; MADEIRA, J.; YOUNG, C.E.F.; SOUZA JUNIOR, W.C. (2014) -Diretrizes Empresariais para a Valoração Econômica de Serviços Ecossistêmicos. Versão 2. FGV/TeSE.

MOTTA, R. S. (2002). Estimativa do custo econômico do desmatamento na Amazônia. Instituto de Pesquisa Econômica Aplicada - IPEA. Ministério do Planejamento, Orçamento e Gestão. Rio de Janeiro, 2002.

MUNDY, B. The Impact of Hazardous and Toxic Material on Property Value Revisited. The Appraisal Journal, october, 1992. pp. 463-471.

NATIONAL OCEANIC AND ATMOSPHERIC ADMINISTRATION - NOAA (2000). Habitat Equivalency Analysis: an overview. Damage Assessment and Restoration Program. USA: Washington D.C..

NAVAL FACILITIES ENGINEERING COMMAND - NAVFAC (2001) - Air sparging guidance document, Final. NFESC, Technical Report TR-2193-ENV. California/EUA. 
NEW SOUTH WALES - NSW ( 2017) - Valuation of contaminated land. ISSN 22039600, ValuerGeneral'sPolicy.Disponível em: www.ovg.nsw.gov.au. Acesso em 16 de novembro de 2017.

NOGUEIRA, J. M.; MEDEIROS, M. A. A.; ARRUDA, F. (2000) - Valoração econômica do meio ambiente: ciência ou empirismo? In: Cadernos de ciência e tecnologia. Brasília: Embrapa, maio/ago. v. 17, n. 2, p. 81-115.

NOBRE, M.M.; NOBRE, R.C.M. (2008) - Remediação de solos: Técnicas alternativas melhoram desempenho. In Química e Derivados vol.31 Outubro/2008. Disponível em http://www.quimica.com.br/revista/qd417/solo1.htm.Acessoem 16 de novembro de 2017.

NZ REAL PROPERTY GUIDANCE - NZRPGN (1995) - Valuation of contaminated land. The Standards Committee New Zealand Institute of Valuers. Wellington, Nova Zelândia.

OLIVEIRA, E. (2016) - Hidrogeologia Ambiental : Contaminação de Solo e Águas Subterrâneas. São Paulo, SP, 2016.

PEARCE, D.; MARKANDYA, A.; BARBIER, E.B. (1991) - Blueprint for a green economy. Earth-scan publication Itd, Londres Chap 3, pp55-81.

PEIXOTO, S.; WILLMERSDORF, O. (Coord.) Modelo de valoração econômica dos impactos ambientais em unidades de conservação: empreendimentos de comunicação, rede elétrica e dutos. Estudo preliminar. Instituto Brasileiro do Meio Ambiente e dos Recursos Naturais Renováveis - IBAMA. Setembro, 2002. Disponível em: http://www.biodiversidade.rs.gov.br/arquivos/1161519935Modelo de valoracao economica dos impactos ambientais em unidades de conservacao.pdf, acesso em: 25 de outubro de 2007.

PELLI NETO, A (2003) - Curso de Engenharia de Avaliação Imobiliária - Fundamentos e Aplicação da Estatística Inferencial, Belo Horizonte/MG.

PICCHI, A.R.; MATAI. P.H.; PEREIRA, S.P. (2009) - Utilização de meios construtivos em obras civis como alternativa de remediação - Paredes diafragmas. I Cong. Int. de Meio Ambiente Subterrâneo. São Paulo. 
PLIENINGER, T. (2013) land use policy assessing, mapping and quantifying cultural ecosystem services at community level. Land use policy, v.33, p.118-129.

POMPÉIA, S.L. (1996) - Áreas degradas por Poluição: Procedimentos Técnicos para a recuperação. Revista Saneamento Ambiental, 7 .(37): p.14-18.

PUGA, B, P.;ALY JUNIOR, O.; HIRATA, R.C.A.; BERTOLO, R.A. (2015) - Valoração de serviços ecossitêmicos de águas subterrâneas: notas introdutórias. XVIII Cong. Bras. De Águas Subterrâneas, Rev. Águas Subterrâneas, Disponível em:https://aguassubterraneas.abas.org/asubterraneas/article/view/28372.

Acesso em: 06 de novembro de 2018.

REBOUÇAS, A.C. (1994) In: Metodologia de Evaluacion de Sistemas Aquíferos. II Cong. Lat. Amer. de Hidrologia Subterrânea. Curso Pré-Congresso. Santiago Chile.

REBOUÇAS, A., BRAGA,B., TUNDISI, J. G., (2006). Águas doces no Brasil: capital ecológico, uso e conservação, SP: Escrituras Editora, $3^{a}$. Edição.

RIBAS, L. C. (1996). Metodologia e valoração de danos ambientais - caso florestal. Tese (Doutorado) - Escola Politécnica da Universidade de São Paulo, USP, São Paulo/SP.

ROMA, J.C.; SACCARO Jr., N.L.; MATTION, L.F.; PAULSEN, S.S.; VASCONCELLOS; P.G (2013) - A economia de ecossistemas e da biodiversidade no brasil (TEEB-BRASIL), Texto para discussão. Rio de Janeiro/RJ.

SÃO PAULO, Estado de (1989). Constituição Estadual. Constituição do Estado de São Paulo publicada em 05 de Outubro de 1989. Disponível em: https://www.al.sp.gov.br/repositorio/legislacao/constituicao/ 1989/compilacaoconstituicao-0-05.10.1989.html, Acesso em: 07 de maio de 2018.

SÃO PAULO, Estado de (1997). Lei n 9.509, de 20 de Março de 1997 - Dispõe sobre a Política Estadual do Meio Ambiente, seus fins e mecanismos de formulação e aplicação. Disponível em: https://www.al.sp.gov.br/norma/?id=9375, Acesso em: 07 de maio de 2018. 
SÃO PAULO, Estado de (2002). Decreto $n^{\circ} 46.655$ - Aprova o Regulamento do Imposto sobre Transmissão "Causa Mortis" e Doação de Quaisquer Bens ou Direitos - (ITCMD), de que trata a Lei $n^{\circ} 10.705$, de 28-12-00, alterada pela Lei $n^{\circ}$ 10.992, de 21-12-01. Disponível em: https://www.al.sp.gov.br/norma/3234, Acesso em: 27 de novembro de 2018.

SÃO PAULO, Estado de (2009a). Lei no 13.579, de 13 de Julho de 2009 - Define a Área de Proteção e Recuperação dos Mananciais da Bacia Hidrográfica do Reservatório Billings - APRM-B. Disponível em: https://www.al.sp.gov.br/repositorio/legislacao/lei/2009/lei-1357913.07.2009.html, Acesso em: 20 de dezembro de 2018.

SÃO PAULO, Município de (2009b). Lei no 14.933 de 5 de Junho de 2009 - Institui a Política de Mudança do Clima no Município de São Paulo. Disponível em: https://www.legisweb.com.br/legislacao/?id=179421, Acesso em: 20 de dezembro de 2018.

SÃO PAULO, Estado de (2013a). Decreto $n^{\circ} 59.263$, de 05/06/2013 - Dispõe sobre diretrizes e procedimentos para a proteção da qualidade do solo e gerenciamento de áreas contaminadas, e dá providências correlatas. Disponível em: http://www.al.sp.gov.br/norma/?id=170437, Acesso em: 30 de janeiro de 2017.

SÃO PAULO, Estado de (2013b). Lei 13.577 de 08 de Julho de 2009 - Dispõe sobre diretrizes e procedimentos para a proteção da qualidade do solo e gerenciamento de áreas contaminadas, e dá outras providências correlatas. Disponível em: http://www.al.sp.gov.br/ repositorio/legislacao/lei/2009/lei-13577-08.07.2009.html, Acesso em: 07 de maio de 2018.

SHIDELER, D. \& DICKS, M.R. (2011), Methods for estimating economic damages from environmental contamination. Southern AgriculturalEconomicsAssociationAnnual Meeting, Corpus Christi, TX.

SITE JUSBRASIL (2018) - Linha do tempo: um breve resumo da evolução da legislação ambiental no Brasil. https://sti.jusbrasil.com.br/noticias/ 2219914/linhado-tempo-um-breve-resumo-da-evolucao-da-legislacao-ambiental-no-brasil. Acesso em: 03 de maio de 2018. 
SUKHDEV, P; WITTMER, SCLAACK-SCHRÖTER, C.; NESSHOVER, C.; BISHÖP, P.B; GUNDIMEDA, H.; KUMAR, P.; SIMMONS, B. \& NEUVILLE; A. (2010) - A Economia dos ecossistemas e da biodiversidade: integrando a economia da natureza. Uma síntese da abordagem, conclusões e recomendações do TEEB. Programa das Nações Unidas para o Meio Ambiente, versão traduzida da Confederação nacional da indústria.

THE ECONOMICS OF ECOSYSTEMS AND BIODIVERSITY - TEEB. (2012) - The Economics of Ecosystems and Biodiversity: ecological and economic foundation. New York: Routledge.

THE ECONOMICS OF ECOSYSTEMS AND BIODIVERSITY - TEEB. (2012b) - The Economics of Ecosystems and Biodiversity in Business and Enterprise. London: Earthscan.

TINOCO, J. E. P.; KRAEMER, M. E. P. (2008). Contabilidade e gestão ambiental. 2 ed.São Paulo: Atlas.

TURNER, R.K.; ADGER, W.N.; BROUWER, R. (1998) Ecosystem services value, research needs and police relevance: a commentary. Ecological economics, v.25, p. 61-65.

USEPA - UNITED STATE ENVIRONMENTAL PROTECTION AGENCY (1991). Technology Transfer. Site characterization for subsurface remediation. Washington: US Government Printing Office, 1991. 259 p. (Seminar Publication. EPA/625/4-91/026). Disponívelem: http://www.epa.gov/OUST/cat/sitchasu.pdf. Acessoem: 21.03.2018

USEPA - UNITED STATE ENVIRONMENTAL PROTECTION AGENCY (1996). How to effectively recover free product at leaking underground storage tank sites. 1996. WILSON, D. J.(1995) - Modeling of In Situ Techiniques for Treatment of Contaminated Soils. Technomic Publishing AG, 567pp.

YANCHESKI, T. B. \& MCFARLAND, M. A. (1992) - Bioventing: A Successful Soil Vapor Remediation Technique for the Vadose Zone and Shallow Groundwater Hazardous Materials. Control/Superfund 92: 13th Annual Conference and Exhibition, Hazardous Materials Control Resources Institute. 
10. ANEXOS

ANEXO I - Indicadores econômicos de conversão de valor aplicado.

ANEXO II - Dados básicos das áreas contaminadas avaliadas. 
ANEXO I

Indicadores econômicos de conversão de valor aplicado 
INCC - Indice Nacional de Construção Civil (\%)

\begin{tabular}{|c|c|c|c|c|c|c|c|c|c|c|c|c|c|}
\hline & JAN & FEV & MAR & ABR & MAI & JUN & JUL & AGO & SET & OUT & NOV & DEZ & ACUMULADO \\
\hline 1989 & - & - & - & - & - & 23.59 & 30.79 & 45.87 & 38.04 & 38.59 & 42.35 & 44.84 & $830.05 \%$ \\
\hline 1990 & 51.70 & 70.20 & 72.48 & 38.20 & 1.10 & 4.43 & 11.21 & 13.94 & 12.39 & 11.52 & 12.14 & 14.15 & $1.221 .00 \%$ \\
\hline 1991 & 15.67 & 17.54 & 12.34 & 8.51 & 7.25 & 13.36 & 11.74 & 14.15 & 13.53 & 23.07 & 21.10 & 29.72 & $464.11 \%$ \\
\hline 1992 & 18.25 & 28.24 & 23.47 & 26.74 & 17.74 & 27.55 & 18.78 & 23.19 & 19.51 & 31.33 & 21.01 & 27.75 & $1.165 .24 \%$ \\
\hline 1993 & 19.13 & 34.43 & 23.72 & 32.46 & 27.53 & 36.11 & 27.70 & 33.37 & 31.19 & 36.63 & 36.07 & 38.16 & $2.514 .47 \%$ \\
\hline 1994 & 33.62 & 40.68 & 43.41 & 50.70 & 45.18 & 45.51 & 42.85 & 3.95 & 0.31 & 0.88 & 1.42 & 2.44 & $1.239 .81 \%$ \\
\hline 1995 & 1.37 & 3.54 & 2.41 & 2.74 & 2.43 & 9.38 & 2.71 & 0.93 & 4.68 & 0.72 & 0.76 & 1.07 & $37.71 \%$ \\
\hline 1996 & 0.67 & 1.35 & 0.19 & 0.89 & 0.55 & 2.01 & 1.52 & 0.74 & 0.15 & 0.23 & 0.28 & 0.48 & $9.42 \%$ \\
\hline 1997 & 0.68 & 0.31 & 0.42 & 0.73 & 0.30 & 0.99 & 0.94 & 0.55 & 1.18 & 0.22 & 0.22 & 0.52 & $7.28 \%$ \\
\hline 1998 & 0.29 & 0.48 & 0.31 & -0.46 & 0.47 & 0.86 & 0.42 & 0.29 & 0.09 & 0.05 & 0.07 & -0.01 & $2.74 \%$ \\
\hline 1999 & 0.21 & 0.62 & 0.91 & 0.58 & 0.38 & 0.88 & 0.41 & 0.52 & 0.83 & 0.79 & 1.22 & 0.81 & $8.46 \%$ \\
\hline 2000 & 1.15 & 0.89 & 0.82 & 0.69 & 0.57 & 1.09 & 0.83 & 0.35 & 0.30 & 0.28 & 0.29 & 0.49 & $8.02 \%$ \\
\hline 2001 & 0.40 & 0.55 & 0.34 & 0.28 & 2.00 & 0.69 & 1.07 & 0.56 & 0.59 & 0.92 & 0.60 & 0.70 & $9.03 \%$ \\
\hline 2002 & 0.40 & 0.31 & 0.84 & 0.32 & 2.47 & 0.21 & 0.63 & 0.82 & 0.68 & 0.82 & 2.19 & 2.13 & $12.44 \%$ \\
\hline 2003 & 1.45 & 1.60 & 1.38 & 0.81 & 2.98 & 0.74 & 0.59 & 2.20 & 0.24 & 0.47 & 0.42 & 0.99 & $14.76 \%$ \\
\hline 2004 & 0.28 & 0.48 & 1.59 & 0.60 & 1.74 & 0.56 & 1.12 & 0.90 & 0.67 & 0.95 & 0.94 & 0.61 & $10.94 \%$ \\
\hline 2005 & 0.70 & 0.42 & 0.71 & 0.38 & 0.54 & 2.20 & 0.65 & 0.05 & 0.06 & 0.28 & 0.29 & 0.38 & $6.84 \%$ \\
\hline 2006 & 0.24 & 0.28 & 0.23 & 0.21 & 0.81 & 1.45 & 0.57 & 0.35 & 0.09 & 0.18 & 0.23 & 0.30 & $5.04 \%$ \\
\hline 2007 & 0.45 & 0.26 & 0.17 & 0.43 & 0.55 & 1.67 & 0.21 & 0.35 & 0.39 & 0.49 & 0.48 & 0.43 & $6.03 \%$ \\
\hline 2008 & 0.41 & 0.43 & 0.59 & 0.82 & 1.10 & 2.67 & 1.42 & 1.27 & 0.95 & 0.85 & 0.65 & 0.22 & $11.96 \%$ \\
\hline 2009 & 0.26 & 0.35 & -0.17 & -0.01 & 0.25 & 1.53 & 0.37 & 0.01 & 0.07 & 0.13 & 0.18 & 0.20 & $3.20 \%$ \\
\hline 2010 & 0.52 & 0.35 & 0.45 & 1.17 & 0.93 & 1.77 & 0.62 & 0.22 & 0.20 & 0.15 & 0.36 & 0.59 & $7.56 \%$ \\
\hline 2011 & 0.37 & 0.39 & 0.44 & 0.75 & 2.03 & 1.43 & 0.59 & 0.16 & 0.14 & 0.20 & 0.50 & 0.35 & $7.58 \%$ \\
\hline 2012 & 0.67 & 0.42 & 0.37 & 0.83 & 1.30 & 1.31 & 0.85 & 0.32 & 0.21 & 0.24 & 0.23 & 0.29 & $7.26 \%$ \\
\hline 2013 & 0.39 & 0.80 & 0.28 & 0.84 & 1.24 & 1.96 & 0.73 & 0.31 & 0.43 & 0.33 & 0.27 & 0.22 & $8.06 \%$ \\
\hline 2014 & 0.70 & 0.44 & 0.22 & 0.67 & 1.37 & 1.25 & 0.80 & 0.19 & 0.16 & 0.20 & 0.30 & 0.25 & $6.74 \%$ \\
\hline 2015 & 0.70 & 0.50 & 0.36 & 0.65 & 0.45 & 1.87 & 0.66 & 0.80 & 0.22 & 0.27 & 0.40 & 0.12 & $7.21 \%$ \\
\hline 2016 & 0.32 & 0.52 & 0.79 & 0.41 & 0.19 & 1.52 & 1.09 & 0.26 & 0.37 & 0.17 & 0.17 & 0.36 & $6.33 \%$ \\
\hline 2017 & 0.29 & 0.53 & 0.36 & -0.08 & 0.13 & 1.36 & 0.22 & 0.40 & 0.14 & 0.19 & 0.28 & 0.14 & $4.02 \%$ \\
\hline 2018 & 0.28 & 0.14 & 0.23 & 0.28 & 0.30 & 0.76 & 0.72 & 0.30 & 0.17 & 0.33 & 0.26 & - & $3.83 \%$ \\
\hline
\end{tabular}




\section{DOLAR AMERICANO (1 Real)}

\begin{tabular}{|c|c|c|c|c|c|c|c|c|c|c|c|c|c|c|c|c|c|c|c|c|c|c|c|c|c|c|c|}
\hline & & & & & & & & & & & & & & & & & & & & & & & & & & & \\
\hline Janeiro & & 0.117 & 0.847 & 0.972 & 1.039 & 0.112 & 1.208 & 1.806 & 1.950 & 2.311 & 3.540 & 2.892 & 2.656 & 2.338 & 2.274 & 2.139 & 1.774 & 1.778 & 1.778 & 1.675 & 1.791 & 2.031 & 2.382 & 2.638 & 4.054 & 3.197 & 3.21 \\
\hline Fevereiro & & 0.086 & 0.849 & 0.966 & 1.033 & 0.111 & 1.202 & 1.923 & 1.980 & 2.495 & 3.653 & 2.947 & 2.720 & 2.204 & 2.162 & 2.096 & 1.728 & 1.842 & 1.842 & 1.668 & 1.718 & 1.973 & 2.384 & 2.817 & 3.978 & 3.103 & 3.24 \\
\hline Março & & 0.063 & 0.845 & 0.962 & 1.028 & 0.110 & 1.193 & 1.948 & 1.900 & 2.696 & 3.650 & 2.867 & 2.859 & 2.252 & 2.152 & 2.089 & 1.708 & 1.786 & 1.786 & 1.659 & 1.795 & 1.983 & 2.326 & 3.140 & 3.694 & 3.127 & 3.28 \\
\hline Abril & & 0.047 & 0.853 & 0.953 & 1.021 & 0.110 & 1.184 & 1.937 & 1.844 & 2.670 & & 2.893 & & 2.228 & 2.129 & 2.033 & 1.689 & 1.757 & 1.757 & 1.586 & 1.855 & 2.002 & 2.233 & 3.044 & 3.551 & 3.140 & 3.41 \\
\hline Maio & & 0.034 & 0.886 & 0.949 & 1.017 & 0.109 & 1.177 & 1.918 & 1.824 & 2.564 & 3.008 & 2.979 & 2.927 & 2.356 & 2.204 & 1.982 & 1.661 & 1.813 & 1.813 & 1.614 & 1.986 & 2.035 & 2.221 & 3.064 & 3.549 & 3.209 & 3.63 \\
\hline Junho & & 0.026 & 0.937 & 0.935 & 1.014 & 0.108 & 1.163 & 1.803 & 1.784 & 2.473 & 3.460 & 2.968 & 3.038 & 2.380 & 2.248 & 1.932 & 1.619 & 1.807 & 1.807 & 1.587 & 2.049 & 2.173 & 2.236 & 3.111 & 3.418 & 3.297 & 3.78 \\
\hline Julho & & 0.020 & 0.963 & 0.919 & 1.004 & & 1.157 & & 1.807 & & & & & & 2.189 & 1.882 & 1.591 & 1.770 & 1.770 & 1.564 & 2.029 & 2.252 & 2.225 & 3.224 & 3.278 & 3.205 & 3.82 \\
\hline Agosto & & 0.015 & 0.682 & 0.906 & 0.998 & 0.107 & 1.151 & 1.720 & 1.824 & 2.381 & 2.518 & 2.974 & 3.189 & 2.410 & 2.156 & 1.966 & 1.612 & 1.760 & 1.760 & 1.597 & 2.029 & 2.342 & 2.268 & 3.515 & 3.208 & 3.153 & 3.93 \\
\hline Setembro & & 0.012 & 0.474 & 0.918 & 0.992 & 0.106 & 1.144 & 1.666 & 1.805 & 2.201 & 2.361 & 2.911 & 2.931 & 2.528 & 2.169 & 1.900 & 1.800 & 1.719 & 1.719 & 1.750 & 2.028 & 2.270 & 2.333 & 3.896 & 3.256 & 3.138 & 4.11 \\
\hline Outubro & & 0.010 & 0.332 & 0.900 & 0.988 & 0.106 & 1.137 & 1.718 & 1.740 & 2.153 & 2.325 & 3.364 & 2.896 & 2.680 & 2.148 & 1.801 & 2.173 & 1.684 & 1.684 & 1.773 & 2.029 & 2.189 & 2.448 & 3.876 & 3.186 & 3.196 & 3.76 \\
\hline Novembro & & 0.008 & 0.232 & 0.851 & 0.985 & 0.105 & 1.130 & 2.035 & 1.768 & 2.046 & 2.365 & 3.570 & 2.906 & 2.590 & 2.158 & 1.770 & 2.266 & 1.713 & 1.713 & 1.791 & 2.067 & 2.297 & 2.538 & 3.778 & 3.339 & 3.257 & 3.79 \\
\hline zembro & & 0.006 & 0.167 & 0.841 & 0.978 & 0.105 & 1.123 & 2.085 & 1.784 & 1.971 & 2.413 & 3.504 & 2.935 & 2.609 & 2.150 & 1.787 & 2.398 & 1.695 & 1.695 & 1.837 & 2.080 & 2.345 & 2.644 & 3.869 & 3.351 & 3.297 & \\
\hline soma & & 0.444 & 8.064 & 11.070 & 12.096 & 1.297 & 13.968 & 22.311 & 22.008 & 28.272 & 35.870 & 36.703 & 35.002 & 28.909 & 26.139 & 23.377 & 22.019 & 21.124 & 21.124 & 20.101 & 23.456 & 25.892 & 28.238 & 39.972 & 41.862 & 38.319 & 39.972 \\
\hline média & & 0.037 & 0.672 & 0.922 & 1.008 & 0.108 & 1.164 & 1.859 & 1.834 & 2.356 & 2.989 & 3.059 & 2.917 & 2.409 & 2.178 & 1.948 & 1.835 & 1.760 & 1.760 & 1.675 & 1.955 & 2.158 & 2.353 & 3.331 & 3.489 & 3.193 & 3.634 \\
\hline
\end{tabular}


ANEXO II

Dados básicos das áreas contaminadas avaliadas 


\begin{tabular}{|c|c|c|c|c|c|c|c|c|c|c|c|c|c|c|c|c|c|c|c|c|c|c|c|c|c|}
\hline \multirow[b]{2}{*}{ ID } & \multirow[b]{2}{*}{$\begin{array}{r}\text { Data } \\
\text { Registro }\end{array}$} & \multirow{2}{*}{$\begin{array}{l}\text { IDENTIFICAÇĀO } \\
\text { Cidade }\end{array}$} & & & RENCC & CONAN & A / CET & & & DADOS & OPOSTO & & exto geoló & gico & FASE I & APOR & FASE & ETIDA & LNA & & & iolv & & & \\
\hline & & & AvP & Ic & ID & Artx & PI & REM & ME & $\begin{array}{c}\text { Área } \\
\mathrm{m} 2\end{array}$ & $\begin{array}{l}\text { Data } \\
\text { instala }\end{array}$ & Sed. & $\begin{array}{c}\text { Rocha } \\
\text { alterada }\end{array}$ & $\begin{array}{l}\text { ZN Sat } \\
(\mathrm{m})\end{array}$ & $\begin{array}{c}\text { Detectado } \\
? ?\end{array}$ & $\begin{array}{c}\text { Delimitado } \\
?\end{array}$ & $\begin{array}{c}\text { Detectado } \\
?\end{array}$ & $\begin{array}{c}\text { Delimitado } \\
?\end{array}$ & $\left|\begin{array}{c}\text { Detectado } \\
?\end{array}\right|$ ? & Delimit & $\begin{array}{c}\text { Detectado } \\
?\end{array}$ & $\begin{array}{c}\text { Delimitada } \\
?\end{array}$ & $\mid \begin{array}{c}\text { Remediação } \\
?\end{array}$ & $\begin{array}{c}\text { Remediação } \\
\text { Z Nsatu? }\end{array}$ & $\begin{array}{c}\text { kemediaçã } \\
\text { Z Sat? }\end{array}$ \\
\hline 1 & & São Paulo & Sim & Sim & Não & Não & Não & Não & Não & 259 & 1980 & Sim & Não & 2,8 & Não & Não & Não & & Não & & Sim & Não & Não & Não & Năo \\
\hline 2 & jun-04 & Franca & Sim & Sim & Não & Não & Não & Não & Não & 1500 & 1985 & Sim & Não & 7,5 & Sim & Sim & Não & & Não & & Sim & & Não & Não & Não \\
\hline 3 & jan-02 & Duartina & Sim & Sim & Não & Não & Não & Não & Não & 1500 & 1974 & Sim & Não & 7,5 & Sim & Sim & Não & & Não & & & & Não & Não & Não \\
\hline 4 & $\begin{array}{l}\text { dez-06 } \\
\text { jan-07 }\end{array}$ & \begin{tabular}{|l} 
São Paulo \\
São Paulo
\end{tabular} & Sim & Sim & $\begin{array}{l}\text { Não } \\
\text { Sim }\end{array}$ & Não & Não & Não & Não & 2500 & $\begin{array}{l}1970 \\
1970\end{array}$ & Sim & Não & 6,1 & Não & Não & Não & & Não & & Sim & Não & Não & Não & Não \\
\hline 5 & jan-07| & São Paulo & Não & Não & Sim & Sim & Não & Não & Não & 2500 & 1970 & Sim & Não & 6,1 & Não & Não & Sim & Não & Não & & Sim & Sim & Não & Não & Não \\
\hline $\begin{array}{l}6 \\
7\end{array}$ & jun-07 & $\begin{array}{l}\mid \begin{array}{l}\text { São Paullo } \\
\text { São Paulo }\end{array} \\
\text { a }\end{array}$ & Não & Não & Não & Não & Não & Sim & Não & $\begin{array}{r}2500 \\
2500\end{array}$ & 1970 & Sim & Não & 6,1 & Não & Não & Sim & & Não & & Sim & Sim & Sim & Sim & Não \\
\hline 7 & jul-077 & Săa Paulo & Não & & Não & Năo & Não & Nâo & Sim & $\begin{array}{l}2500 \\
2500\end{array}$ & & Sim & Não & 6,1 & Não & Não & Sim & Não & Não & & Sim & Sim & Não & Não & Não \\
\hline 8 & & $\begin{array}{l}\text { São Paulo } \\
\text { São Pawo }\end{array}$ & Não & Não & Não & Não & Não & Não & Sim & 2500 & 1970 & Sim & Não & 6,1 & Não & Não & Sim & Não & Não & & Sim & Sim & Não & Não & Não \\
\hline 9 & abr-08 & São Paulo & Não & Não & Não & Não & Não & Não & Sim & 2500 & 1970 & Sim & Não & 6,1 & Não & Não & Sim & Não & Não & & Sim & Não & Não & Não & Não \\
\hline 10 & ago-08 & |ã̃o Paulo & Não & Não & Não & Não & Não & Não & Sim & 2500 & 1970 & Sim & Não & 6,1 & Não & Não & Sim & Não & Não & & Sim & Não & Não & Não & Não \\
\hline${ }_{12}^{11}$ & $\begin{array}{l}\text { dez-09 } \\
\text { jul-10 }\end{array}$ & $\begin{array}{l}\text { São Paulo } \\
\text { São Paulo }\end{array}$ & Não & Não & Sim & $\begin{array}{l}\text { Não } \\
\text { Sim }\end{array}$ & $\begin{array}{l}\text { Não } \\
\text { Sim }\end{array}$ & Não & Sim & 2500 & $\begin{array}{l}1970 \\
1970\end{array}$ & Sim & $\begin{array}{l}\text { Não } \\
\text { Não }\end{array}$ & 6,1 & Sim & Não & Sim & Não & Não & & Sim & Não & Não & Não & Não \\
\hline 13 & dez-04 & $\begin{array}{l}\text { Sao Paúo } \\
\text { São Paulo }\end{array}$ & $\begin{array}{l}\text { Nao } \\
\text { Sim }\end{array}$ & $\begin{array}{l}\text { Năo } \\
\text { Sim }\end{array}$ & $\begin{array}{l}\text { Nao } \\
\text { Não }\end{array}$ & $\begin{array}{l}\text { Sim } \\
\text { Não }\end{array}$ & $\begin{array}{l}\text { Sim } \\
\text { Não }\end{array}$ & $\begin{array}{l}\text { Não } \\
\text { Não }\end{array}$ & $\begin{array}{l}\text { Sim } \\
\text { Não }\end{array}$ & $\begin{array}{l}2500 \\
1200\end{array}$ & $\begin{array}{l}1970 \\
1966\end{array}$ & $\begin{array}{l}\text { Sim } \\
\text { Sim }\end{array}$ & $\begin{array}{l}\text { Não } \\
\text { Não }\end{array}$ & $\begin{array}{l}6,1 \\
2,0\end{array}$ & $\begin{array}{l}\text { Sim } \\
\text { Não }\end{array}$ & & $\begin{array}{l}\text { Não } \\
\text { Sim }\end{array}$ & $\begin{array}{l}\text { Não } \\
\text { Não }\end{array}$ & $\begin{array}{l}\text { Não } \\
\text { Não }\end{array}$ & & $\begin{array}{l}\text { Sim } \\
\text { Sim }\end{array}$ & $\begin{array}{l}\text { Não } \\
\text { Não }\end{array}$ & $\begin{array}{l}\text { Não } \\
\text { Não }\end{array}$ & $\begin{array}{l}\text { Não } \\
\text { Não }\end{array}$ & $\begin{array}{l}\text { Não } \\
\text { Não }\end{array}$ \\
\hline 14 & set -05 & São Paulo & Não & Nâo & Sim & Sim & Não & Não & Não & 1200 & 1966 & Sim & Não & 2,0 & Não & & & & Não & & sim & Não & Não & Não & Não \\
\hline 15 & out -05 & São Paulo & Não & Não & Não & Não & Não & Sim & Não & 1200 & 1966 & sim & Não & 2,0 & Não & & & & Não & & sim & Não & Sim & Sim & Não \\
\hline 16 & dez-05 & São Paulo & Não & Não & Não & Não & Não & Não & Sim & 1200 & 1966 & Sim & Não & 2,0 & Não & & Sim & Não & Não & & Sim & Sim & Não & Não & Não \\
\hline 17 & fev-06 & São Paulo & Não & Não & Não & Sim & Não & Não & Não & 1200 & 1966 & Sim & Não & 2,0 & Não & & & & Não & & & & Não & Não & \\
\hline 18 & & São Paulo & Não & Não & Não & & Não & Não & Sim & 1200 & 1966 & sim & Não & 2,0 & Não & & & & Não & & Sim & $\mathrm{Sim}$ & Não & Não & Não \\
\hline 19 & ago-06 & São Paulo & Não & Não & Não & Não & Não & Não & Sim & 1200 & 1966 & Sim & Não & 2,0 & Não & & & & Sim & Sim & Sim & Sim & Não & Não & Não \\
\hline 20 & out-06 & São Paulo & Não & Não & Não & Não & Não & Sim & Não & 1200 & 1966 & Sim & Não & 2,0 & Não & & & & Sim & Sim & Sim & Sim & Sim & Não & Sim \\
\hline 21 & dez-06 & São Paulo & Não & Não & Não & Não & Não & Sim & Não & 1200 & 1966 & sim & Não & 2,0 & Não & & & & sim & Sim & Sim & Sim & sim & Não & Sim \\
\hline 22 & fev-07 & São Paulo & Não & Não & Não & Não & Não & Sim & Sim & 1200 & 1966 & Sim & Não & 2,0 & Não & & & & Sim & Sim & Sim & Sim & Sim & Não & Sim \\
\hline 23 & mai-07 & São Paulo & Não & Não & Sim & Sim & Não & Não & Não & 1200 & 1966 & Sim & Não & 2,0 & Sim & Sim & Sim & Não & Não & & Sim & Sim & Não & Não & Não \\
\hline 24 & out-07 & São Paulo & Não & Não & Não & Não & Não & Não & Sim & 1200 & 1966 & Sim & Não & 2,0 & Sim & Sim & & & Não & & Sim & Sim & & & \\
\hline $\begin{array}{l}25 \\
26\end{array}$ & $\begin{array}{c}\text { mai-08 } \\
\text { ago-08 }\end{array}$ & $\begin{array}{l}\text { Sao Paulo } \\
\text { São Paulo }\end{array}$ & $\begin{array}{l}\text { Não } \\
\text { Nẵo }\end{array}$ & $\begin{array}{l}\text { Não } \\
\text { Não }\end{array}$ & $\begin{array}{l}\text { Não } \\
\text { Năo }\end{array}$ & $\begin{array}{l}\text { Não } \\
\text { Não }\end{array}$ & $\begin{array}{l}\text { Não } \\
\text { Não }\end{array}$ & $\begin{array}{l}\text { Não } \\
\text { Não }\end{array}$ & Sim & $\begin{array}{l}1200 \\
1200\end{array}$ & $\begin{array}{l}1966 \\
1966\end{array}$ & Sim & $\begin{array}{l}\text { Não } \\
\text { Não }\end{array}$ & 2,0 & Sim & Sim & & & $\begin{array}{l}\text { Não } \\
\text { Não }\end{array}$ & & Sim & Sim & Não & Não & Não \\
\hline${ }_{27}^{26}$ & $\begin{array}{l}\text { ago-ous } \\
\text { mai-09 }\end{array}$ & $\begin{array}{l}\text { sao Paulo } \\
\text { São Paulo }\end{array}$ & $\begin{array}{l}\text { Não } \\
\text { Não }\end{array}$ & $\begin{array}{l}\text { Nao } \\
\text { Não }\end{array}$ & $\begin{array}{l}\text { Năo } \\
\text { Não }\end{array}$ & $\begin{array}{l}\text { Năo } \\
\text { Não }\end{array}$ & $\begin{array}{l}\text { Não } \\
\text { Não }\end{array}$ & $\begin{array}{l}\text { Não } \\
\text { Não }\end{array}$ & $\begin{array}{l}\text { Sim } \\
\text { sim }\end{array}$ & $\begin{array}{l}1200 \\
1200\end{array}$ & $\begin{array}{l}1966 \\
1966\end{array}$ & $\begin{array}{l}\text { Sim } \\
\text { Sim }\end{array}$ & $\begin{array}{l}\text { Năo } \\
\text { Não }\end{array}$ & $\begin{array}{l}2,0 \\
2,0\end{array}$ & $\begin{array}{l}\text { Năo } \\
\text { Não }\end{array}$ & & & & $\begin{array}{l}\text { Não } \\
\text { Não }\end{array}$ & & $\begin{array}{l}\text { Sim } \\
\text { sim }\end{array}$ & Sim & & & \\
\hline 28 & $\begin{array}{l}\text { mal-09 } \\
\text { nov-09 }\end{array}$ & São Paulo & $\begin{array}{l}\text { Não } \\
\text { Não }\end{array}$ & $\begin{array}{l}\text { Nao } \\
\text { Nâo }\end{array}$ & $\begin{array}{l}\text { Nao } \\
\text { Não }\end{array}$ & $\begin{array}{l}\text { Nao } \\
\text { Não }\end{array}$ & $\begin{array}{l}\text { Nao } \\
\text { Não }\end{array}$ & $\begin{array}{l}\text { Nao } \\
\text { Não }\end{array}$ & Sim & 1200 & $\begin{array}{l}1966 \\
1966\end{array}$ & $\begin{array}{l}\operatorname{sim} \\
\text { Sim }\end{array}$ & $\begin{array}{l}\text { Nao } \\
\text { Não }\end{array}$ & $\begin{array}{l}2,0 \\
2,0\end{array}$ & $\begin{array}{l}\text { Nao } \\
\text { Não }\end{array}$ & & & & $\begin{array}{l}\text { Nao } \\
\text { Nâo }\end{array}$ & & $\mathrm{Sim}$ & $\mathrm{Sim}$ & & & \\
\hline 29 & mai-10 & São Paulo & Não & $\begin{array}{l}\text { Nao } \\
\text { Não }\end{array}$ & Não & Não & Não & Não & Sim & 1200 & 1966 & Sim & Não & $\begin{array}{l}2,0 \\
2,0\end{array}$ & $\begin{array}{l}\text { Nao } \\
\text { Não }\end{array}$ & & & & $\begin{array}{l}\text { Nao } \\
\text { Não }\end{array}$ & & $\mathrm{Sim}$ & $\mathrm{Sim}$ & & & \\
\hline 30 & nov-10 & São Paulo & Não & Não & Não & Não & Não & Não & sim & 1200 & 1966 & Sim & Não & $\begin{array}{l}2,0 \\
2,0\end{array}$ & Não & & & & Não & & $\mathrm{Sim}$ & $\mathrm{Sim}$ & & & \\
\hline 31 & dez-01 & $\begin{array}{l}\text { São Paulo } \\
\text { Sal }\end{array}$ & Sim & Sim & Não & Não & Não & Não & Não & 690 & 1967 & Sim & Não & 7,0 & & & Sim & Sim & Não & & Sim & Näo & & & \\
\hline 32 & ago-02 & São Paulo & Não & Não & Sim & Sim & Não & Não & Não & 690 & 1967 & Sim & Não & 7,0 & Sim & & Sim & Sim & Não & & Sim & Não & & & \\
\hline 33 & $\mathrm{mar} / 03$ & São Paulo & Não & Não & $\mathrm{Sim}$ & Não & Não & Não & Não & 690 & 1967 & Sim & Não & 7,0 & Sim & & $\mathrm{Sim}$ & Sim & Sim & & sim & Sim & & & \\
\hline 34 & $\mathrm{mai} / 03$ & São Paulo & Não & Não & Não & Não & Sim & Sim & Não & 690 & 1967 & Sim & Não & 7,0 & sim & & Sim & Sim & Sim & Sim & sim & Sim & Sim & & Sim \\
\hline 35 & ago/11 & São Paulo & Não & Não & Não & Não & Não & Sim & Sim & 690 & 1967 & Sim & Não & 7,0 & Sim & & Sim & Não & Sim & Sim & Sim & Sim & Sim & & Sim \\
\hline 36 & out/11 & São Paulo & Não & Não & $\operatorname{Sim}$ & Sim & Não & Não & Não & 690 & 1967 & Sim & Não & 7,0 & Sim & & Sim & Não & Sim & Sim & Sim & Sim & & & \\
\hline 37 & abr/12 & | 5 ão Paulo & Não & Não & Não & Não & Sim & Sim & Não & 690 & $\begin{array}{l}1967 \\
1967\end{array}$ & Sim & Não & 7,0 & Sim & & Não & Não & Sim & Sim & Sim & Sim & Sim & Não & Sim \\
\hline 38 & fev/13 & $\begin{array}{l}\text { São Paulo } \\
\text { São Paulo }\end{array}$ & $\begin{array}{l}\text { Não } \\
\text { Não }\end{array}$ & $\begin{array}{l}\text { Não } \\
\text { Não }\end{array}$ & $\begin{array}{l}\text { Não } \\
\text { Nâno }\end{array}$ & $\begin{array}{l}\text { Não } \\
\text { Não }\end{array}$ & $\begin{array}{l}\text { Não } \\
\text { Não }\end{array}$ & $\begin{array}{l}\text { Sim } \\
\text { Não }\end{array}$ & $\begin{array}{l}\text { Não } \\
\text { Sim }\end{array}$ & $\begin{array}{l}690 \\
690\end{array}$ & $\begin{array}{l}1967 \\
1967\end{array}$ & $\begin{array}{l}\text { Sim } \\
\text { Sim }\end{array}$ & $\begin{array}{l}\text { Não } \\
\text { Nâo }\end{array}$ & $\begin{array}{l}7,0 \\
70\end{array}$ & Sim & & Não & Não & Sim & Sim & Sim & Sim & Sim & Não & Sim \\
\hline & $\begin{array}{r}\text { out-13 } \\
\text { mar-14 }\end{array}$ & $\begin{array}{l}\text { Sao Paulo } \\
\text { São Paulo }\end{array}$ & $\begin{array}{l}\text { Não } \\
\text { Nẵo }\end{array}$ & $\begin{array}{l}\text { Não } \\
\text { Não }\end{array}$ & $\begin{array}{l}\text { Não } \\
\text { Năo }\end{array}$ & $\begin{array}{l}\text { Não } \\
\text { Não }\end{array}$ & $\begin{array}{l}\text { Não } \\
\text { Não }\end{array}$ & $\begin{array}{l}\text { Não } \\
\text { Sim }\end{array}$ & $\begin{array}{l}\text { Sim } \\
\text { Sim }\end{array}$ & $\begin{array}{l}690 \\
690\end{array}$ & $\begin{array}{l}1967 \\
1967\end{array}$ & $\begin{array}{l}\text { Sim } \\
\text { Sim }\end{array}$ & $\begin{array}{l}\text { Não } \\
\text { Năo }\end{array}$ & $\begin{array}{l}7,0 \\
7,0\end{array}$ & $\begin{array}{l}\text { Sim } \\
\text { Sim }\end{array}$ & & $\begin{array}{l}\text { Não } \\
\text { Năo }\end{array}$ & $\begin{array}{l}\text { Não } \\
\text { Năo }\end{array}$ & $\begin{array}{l}\text { Sim } \\
\text { Sim }\end{array}$ & $\begin{array}{l}\text { Sim } \\
\text { Sim }\end{array}$ & $\begin{array}{l}\text { Sim } \\
\text { Sim }\end{array}$ & Sim & & & \\
\hline $\begin{array}{l}40 \\
41\end{array}$ & $\begin{array}{l}\text { mar-14 } \\
\text { mar-15 }\end{array}$ & $\begin{array}{l}\text { sao Paulo } \\
\text { Sâo Paulo }\end{array}$ & $\begin{array}{l}\text { Não } \\
\text { Não }\end{array}$ & $\begin{array}{l}\text { Não } \\
\text { Não }\end{array}$ & $\begin{array}{l}\text { Năo } \\
\text { Não }\end{array}$ & $\begin{array}{l}\text { Nâo } \\
\text { Não }\end{array}$ & $\begin{array}{l}\text { Não } \\
\text { Não }\end{array}$ & $\begin{array}{l}\text { Sim } \\
\text { Não }\end{array}$ & $\begin{array}{l}\text { Sim } \\
\text { Sim }\end{array}$ & $\begin{array}{l}690 \\
690\end{array}$ & $\begin{array}{l}196 / \\
1967\end{array}$ & $\begin{array}{l}\text { Sim } \\
\text { Sim }\end{array}$ & $\begin{array}{l}\text { Năo } \\
\text { Não }\end{array}$ & $\begin{array}{l}7,0 \\
7,0\end{array}$ & Sim & & $\begin{array}{l}\text { Não } \\
\text { Não }\end{array}$ & $\begin{array}{l}\text { Năo } \\
\text { Não }\end{array}$ & $\begin{array}{l}\text { Sim } \\
\text { Sim }\end{array}$ & $\begin{array}{l}\text { Sim } \\
\text { Sim }\end{array}$ & $\begin{array}{l}\text { Sim } \\
\text { Sim }\end{array}$ & Sim & & & \\
\hline $\begin{array}{l}41 \\
42\end{array}$ & out-15 & $\begin{array}{l}\text { São Paulo } \\
\text { sal }\end{array}$ & Não & Não & Não & $\begin{array}{l}\text { Nao } \\
\text { Não }\end{array}$ & $\begin{array}{l}\text { Nao } \\
\text { Não }\end{array}$ & $\begin{array}{l}\text { Nao } \\
\text { Não }\end{array}$ & Sim & 690 & 1967 & 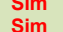 & $\begin{array}{l}\text { Nao } \\
\text { Não }\end{array}$ & $\begin{array}{l}7,0 \\
7,0\end{array}$ & & & & Não & & & $\mathrm{Sim}$ & sim & & & \\
\hline 43 & jul-02 & São Paulo & Sim & Não & Não & Não & Não & Não & Não & 1300 & 1950 & Sim & Não & 10,0 & & & & & Não & & & & & & \\
\hline 44 & jan-03 & São Paulo & Näo & Sim & Não & Não & Não & Não & Não & 1300 & 1950 & Sim & Não & 10,0 & sim & & Sim & & Sim & & $\operatorname{sim}$ & Não & & & \\
\hline 45 & out -05 & São Paulo & Não & Nẫo & Sim & Sim & Sim & Não & Não & 1300 & 1950 & Sim & Não & 10,0 & Sim & Não & sim & & sim & Sim & Sim & Não & & & \\
\hline 46 & dez-05 & São Paulo & Não & Não & Não & Não & Não & Sim & Não & 1300 & 1950 & Sim & Não & 10,0 & Sim & Não & $\mathrm{Sim}$ & & Sim & Sim & Não & & Sim & Sim & \\
\hline 47 & jan-06 & São Paulo & & Não & Sim & Sim & Não & Não & Não & 1300 & 1950 & Sim & Nầ & 10,0 & Sim & Não & Sim & & Sim & Sim & Sim & Sim & Sim & & \\
\hline 48 & jan-06 & São Paulo & Não & Não & Não & Não & Não & Sim & Não & 130 & 1950 & Sim & Não & 10,0 & Sim & Não & Sim & & Sim & $\mathrm{m}$ & Sim & Sim & Sim & & Sim \\
\hline 49 & mar-06 & São Paulo & & Não & Não & Não & Não & Sim & & $13 \mathrm{C}$ & 1950 & & Não & 10,0 & Sim & Não & Sim & & Sim & Sim & Sim & Sim & Sim & & \\
\hline 50 & jul-08 & São Paulo & Nã & Não & Não & Não & Não & Sim & Nã & 130 & 1950 & sim & Não & 10 & Sim & Não & Sim & & $\mathrm{Sin}$ & Sim & Sim & sim & Sim & & sim \\
\hline 51 & mar-08 & São Paulo & & Não & Sim & Sim & Não & Sim & Não & 1300 & 1950 & Sim & Não & 10,0 & Sim & Sim & Sim & & $\mathrm{Sin}$ & Sim & Sim & Sim & Sim & & sim \\
\hline 52 & out-08 & São Paulo & & Não & Não & Não & Sim & Sim & Não & 1300 & 1950 & Sim & Não & 10,0 & Sim & Sim & Sim & & Sim & sim & Sim & $\mathrm{Sim}$ & Sim & Sim & Sim \\
\hline 53 & jun-09 & São Paulo & Não & Não & Não & Não & Não & Sim & $N^{n} \bar{c}$ & 13 & 195 & Sim & Não & 10,0 & Sim & Sim & Sim & & Sim & Sim & Sim & Sim & Sim & Sim & Sim \\
\hline 54 & set- 09 & São Paulo & Não & Não & Não & Não & Não & Sim & $\mathrm{N}$ & 13 & 195 & Sin & Não & 10,0 & Sim & Sim & Sim & & Sim & Sim & Sim & Sim & Sim & Sim & Sim \\
\hline 55 & jan-10 & São Paulo & & Não & Não & Não & Não & Sim & & 13 & & & Não & 10 & Sim & Sim & & & & & & Sim & & Sim & Sim \\
\hline 56 & mai-10 & São Paulo & & Não & Não & Não & Não & Sim & & 130 & & & $\mathrm{~N}_{\hat{c}}$ & 10 & Sim & Sim & & & Nầ & & & & & Sim & sim \\
\hline 57 & dez-10 & São Paulo & Não & Não & $\mathrm{Sim}$ & Sim & Não & Sim & Não & 1300 & 1950 & Sim & Não & 10,0 & sim & sim & sim & & Não & & $\mathrm{Sim}$ & $\mathrm{Sim}$ & $\mathrm{Sim}$ & Sim & sim \\
\hline 58 & mar-11 & São Paulo & Nẫ & Não & Não & Não & Não & Sim & Nẫ & 1300 & 1950 & Sim & Não & 10,0 & sim & Sim & sim & & Não & & & Sim & Sim & Sim & sim \\
\hline 59 & & São Paulo & Nã & Não & Não & Não & Não & Sim & Nâo & 13 & 1950 & Sim & Não & 10 & sim & $\mathrm{Sim}$ & sim & & Não & & & & Sim & & Sim \\
\hline 60 & nov-11 & São Paulo & Não & Não & Não & Não & Não & Sim & $\mathrm{N}_{\mathrm{a}}^{\mathrm{a}}$ & 13 & 195 & $\mathrm{Si}$ & Não & 10 & Sim & Sim & $\operatorname{Sin}$ & & Não & & & & Sim & & Sim \\
\hline 61 & mar-12 & São Paulo & Não & Não & Não & Não & Não & Sim & Não & 130 & 1950 & Sim & Não & 10,0 & Sim & Sim & Sim & & Não & & & & Sim & & Sim \\
\hline 62 & jul-12 & São Paulo & Não & Não & Não & Não & Não & Sim & Não & 130 & 1950 & Sim & Não & 10,0 & Sim & Sim & Sim & & Não & & & & Sim & & Sim \\
\hline 63 & nov-12 & São Paulo & Nã & Não & Não & Não & Não & Sim & Não & $13 c$ & 1950 & sim & Não & 10,0 & Sim & Sim & Sim & & Não & & & & Sim & & Sim \\
\hline 64 & mar-13 & São Paulo & Não & Não & Não & Não & Não & Sim & Não & 1300 & 1950 & Sim & Não & 10,0 & Sim & Sim & sim & & Não & & & & $\mathrm{Sim}$ & & Sim \\
\hline 65 & jul-13 & São Paulo & Nầ & Não & Não & Não & no & Sim & Nã & 13 & 19 & Sim & Não & 10 & Sim & Sim & Sim & & Não & & & & sim & & Sim \\
\hline 66 & dez-10 & São Paulo & Não & Não & $\mathrm{Sim}$ & Sim & Não & Não & Não & 1300 & 1950 & Sim & Não & 10,0 & Sim & Sim & sim & Não & Não & & Sim & Sim & sim & & Sim \\
\hline 67 & dez-15 & São Paulo & Não & Não & Não & Não & Não & Sim & Não & 1300 & 1950 & Sim & Não & 10,0 & Sim & Sim & Sim & Não & Não & & Sim & Sim & Sim & & Sim \\
\hline 68 & mai-16 & São Paulo & Não & Não & Não & Não & Não & Sim & Não & 1300 & 1950 & Sim & Não & 10,0 & Sim & Sim & Não & & Não & & Sim & Sim & Sim & & Sim \\
\hline
\end{tabular}




\begin{tabular}{|c|c|c|c|c|c|c|c|c|c|c|c|c|c|c|c|c|c|c|c|c|c|c|c|c|c|}
\hline \multirow[b]{2}{*}{ ID } & \multirow[b]{2}{*}{$\begin{array}{c}\text { Data } \\
\text { Registro }\end{array}$} & \multirow{2}{*}{$\begin{array}{l}\text { IDENTIFICAÇ̄̃O } \\
\text { Cidade }\end{array}$} & & & RENC & ONAM & A / CET & ESB & & DADOS & OPOSTO & & exto geoló & gico & FASE & APOR & FASE & ETIDA & LNA & & & olv & & & \\
\hline & & & AvP & IC & ID & Artx & PI & REM & ME & $\begin{array}{c}\text { Área } \\
\mathrm{m} 2\end{array}$ & $\begin{array}{l}\text { Data } \\
\text { instala }\end{array}$ & Sed. & \begin{tabular}{|c|} 
Rocha \\
alterada
\end{tabular} & $\begin{array}{c}\text { ZN Sat } \\
(\mathrm{m})\end{array} \mid$ & $\begin{array}{c}\text { Detectado } \\
?\end{array}$ & $\begin{array}{c}\text { Delimitado } \\
?\end{array}$ & $\begin{array}{c}\text { Detectado } \\
?\end{array}$ & $\begin{array}{c}\text { Delimitado } \\
?\end{array}$ & $\left.\mid \begin{array}{c}\text { Detectado } \\
?\end{array}\right] ?$ & Delimit & $\begin{array}{c}\text { Detectado } \\
?\end{array}$ & $\begin{array}{c}\text { Delimitada } \\
?\end{array}$ & $\begin{array}{c}\text { Remediação } \\
?\end{array}$ & $\begin{array}{c}\text { Remediação } \\
\text { Z Nsatu? }\end{array}$ & $\begin{array}{l}\text { kemediaçã } \\
\text { Z Sat? }\end{array}$ \\
\hline 69 & & São Paulo & Não & Não & Não & Não & Não & Sim & Não & 1300 & 1950 & $\operatorname{sim}$ & Não & 10,0 & Não & Não & Não & & Não & & Sim & Sim & Sim & & Sim \\
\hline 70 & jul-17 s & $\begin{array}{l}\text { São Paulo } \\
\text { c̃o Dual }\end{array}$ & $\begin{array}{l}\text { Não } \\
\text { Nâo }\end{array}$ & $\begin{array}{l}\text { Nã } \\
\text { Nã } \\
\text { Nân }\end{array}$ & $\begin{array}{l}\text { Não } \\
\text { Não }\end{array}$ & $\begin{array}{l}\text { Não } \\
\text { Não }\end{array}$ & Não & Não & Sim & $\begin{array}{l}1300 \\
1300\end{array}$ & $\begin{array}{l}1950 \\
1950\end{array}$ & sim & $\begin{array}{l}\text { Não } \\
\text { Nân }\end{array}$ & $\begin{array}{l}10,0 \\
10,0\end{array}$ & Tau & INau & Nau & & $\begin{array}{l}\text { Não } \\
\text { Nã }\end{array}$ & & 年 & Jimi & . & & (IIII \\
\hline $\begin{array}{l}71 \\
72\end{array}$ & $\begin{array}{l}\text { fev-18 } \\
\text { out-12 }\end{array}$ & $\begin{array}{l}\text { Sáa Paulo } \\
\text { Franca }\end{array}$ & $\begin{array}{l}\text { Não } \\
\text { Não }\end{array}$ & $\begin{array}{l}\text { Não } \\
\text { Sim }\end{array}$ & $\begin{array}{l}\text { Não } \\
\text { Não }\end{array}$ & $\begin{array}{l}\text { Não } \\
\text { Não }\end{array}$ & $\begin{array}{l}\text { Não } \\
\text { Não }\end{array}$ & $\begin{array}{l}\text { Não } \\
\text { Não }\end{array}$ & $\begin{array}{l}\text { Sim } \\
\text { Não }\end{array}$ & $\begin{array}{c}1300 \\
600\end{array}$ & $\begin{array}{l}1950 \\
1977\end{array}$ & $\begin{array}{l}\text { Sim } \\
\text { Sim }\end{array}$ & $\begin{array}{l}\text { Não } \\
\text { Não }\end{array}$ & $\begin{array}{l}10,0 \\
9,0\end{array}$ & Sim & Sim & Sim & & $\begin{array}{l}\text { Não } \\
\text { Não }\end{array}$ & & & Sim & Sim & & Sim \\
\hline & out-12 F & $\begin{array}{l}\text { Franca } \\
\text { France }\end{array}$ & Não & Não & Sim & Sim & Não & Não & $\begin{array}{l}\text { Nao } \\
\text { Nâo }\end{array}$ & 600 & 1977 & $\begin{array}{l}\text { Sim } \\
\text { Sim }\end{array}$ & $\begin{array}{l}\text { Nao } \\
\text { Não }\end{array}$ & $\begin{array}{l}9,0 \\
9,0\end{array}$ & Sim & $\mathrm{Sim}_{\mathrm{Sim}}$ & Sim & $\mathrm{Sim}_{\mathrm{Sim}}$ & $\begin{array}{l}\text { Nao } \\
\text { Não }\end{array}$ & & Sim & Sim & Sim & $\mathrm{Sim}_{\mathrm{Sim}}$ & Sim \\
\hline 74 & jul-13 F & Franca & Não & Não & Não & Não & Não & Sim & Não & 600 & 1977 & Sim & Não & 9,0 & $\mathrm{Sim}$ & $\mathrm{Sim}$ & $\mathrm{Sim}$ & $\mathrm{Sim}$ & Não & & $\mathrm{Sim}$ & $\mathrm{Sim}$ & $\mathrm{Sim}$ & sim & sim \\
\hline 75 & set-13 F & Franca & Não & Não & Não & Não & Não & Sim & Não & 600 & 1977 & Sim & Não & 9,0 & Sim & $\mathrm{Sim}$ & Sim & $\mathrm{Sim}$ & Não & & Sim & Sim & $\mathrm{Sim}$ & sim & sim \\
\hline 76 & nov-13 F & Franca & Não & Não & Não & Não & Não & Sim & Não & 600 & 1977 & Sim & Não & 9,0 & Sim & $\mathrm{Sim}$ & $\mathrm{Sim}$ & Sim & Não & & $\mathrm{Sim}$ & Sim & $\mathrm{Sim}$ & Sim & Sim \\
\hline 77 & abr-15 F & Franca & Não & Não & Não & Não & Sim & Não & Sim & 600 & 1977 & Sim & Não & 9,0 & sim & Sim & & & Não & & $\mathrm{Sim}$ & $\mathrm{Sim}$ & & & \\
\hline 78 & out-15 $F$ & Franca & Não & Não & Não & Não & Não & Não & sim & 600 & 1977 & sim & Não & 9,0 & sim & Sim & & & Não & & Sim & Sim & & & \\
\hline 79 & mar-16 $\mathrm{F}$ & Franca & Não & Não & Não & Não & Não & Sim & Sim & 600 & 1977 & Sim & Não & 9,0 & Sim & Sim & & & Não & & Sim & Sim & Sim & Sim & Sim \\
\hline 80 & jun-16 $F$ & Franca & Não & Não & Sim & Não & Não & Não & Não & 600 & 1978 & Sim & Não & 9,0 & Sim & Sim & & & Não & & Sim & Sim & & & \\
\hline 81 & ago-16 $\mathrm{F}$ & Franca & Não & Não & Não & Não & Não & Sim & Não & 600 & $\begin{array}{l}1979 \\
1077\end{array}$ & Sim & Não & 9,0 & Sim & Sim & Não & Não & Não & & Sim & Sim & Sim & Sim & Sim \\
\hline 83 & $\begin{array}{l}\text { mai-17 } \\
\text { mai-12 }\end{array}$ & $\begin{array}{l}\text { Franca } \\
\text { Osasco }\end{array}$ & $\begin{array}{l}\text { Não } \\
\text { Não }\end{array}$ & $\begin{array}{l}\text { Não } \\
\text { Não }\end{array}$ & $\begin{array}{l}\text { Não } \\
\text { Sim }\end{array}$ & $\begin{array}{l}\text { Não } \\
\text { Sim }\end{array}$ & $\begin{array}{l}\text { Não } \\
\text { Não }\end{array}$ & $\begin{array}{l}\text { Não } \\
\text { Não }\end{array}$ & $\begin{array}{l}\text { Sim } \\
\text { Não }\end{array}$ & $\begin{array}{l}600 \\
1280\end{array}$ & $\begin{array}{l}1977 \\
1997\end{array}$ & Sim & $\begin{array}{l}\text { Não } \\
\text { Năo }\end{array}$ & $\begin{array}{l}9,0 \\
11\end{array}$ & $\begin{array}{l}\text { Sim } \\
\text { Não }\end{array}$ & $\begin{array}{l}\text { Sim } \\
\text { Não }\end{array}$ & & & $\begin{array}{l}\text { Não } \\
\text { Sim }\end{array}$ & & Sim & Sim & Não & Não & \\
\hline $\begin{array}{l}83 \\
84\end{array}$ & $\underset{\text { jul-13 }}{\text { mal-12 }}$ & $\begin{array}{l}\text { Osasco } \\
\text { Osasco }\end{array}$ & $\begin{array}{l}\text { Não } \\
\text { Não }\end{array}$ & $\begin{array}{l}\text { Não } \\
\text { Não }\end{array}$ & $\begin{array}{l}\text { Sim } \\
\text { Não }\end{array}$ & $\begin{array}{l}\text { Sim } \\
\text { Não }\end{array}$ & $\begin{array}{l}\begin{array}{l}\text { Não } \\
\text { Não }\end{array}\end{array}$ & $\begin{array}{l}\text { Não } \\
\text { Saim }\end{array}$ & $\begin{array}{l}\text { Não } \\
\text { Sim }\end{array}$ & $\begin{array}{l}1280 \\
1280\end{array}$ & $\begin{array}{l}1997 \\
1997\end{array}$ & $\begin{array}{l}\text { Sim } \\
\text { Sim }\end{array}$ & $\begin{array}{l}\text { Não } \\
\text { Não }\end{array}$ & $\begin{array}{l}1,1 \\
1,1\end{array}$ & $\begin{array}{l}\text { Não } \\
\text { Não }\end{array}$ & $\begin{array}{l}\text { Não } \\
\text { Não }\end{array}$ & & & $\begin{array}{l}\text { Sim } \\
\text { Sim }\end{array}$ & Sim & $\begin{array}{l}\text { Sim } \\
\text { Sim }\end{array}$ & $\begin{array}{l}\text { Não } \\
\text { Sim }\end{array}$ & $\operatorname{sim}$ & sim & \\
\hline 85 & dez-13 & $\begin{array}{l}\text { Osasco } \\
\text { Osaso }\end{array}$ & $\begin{array}{l}\text { Noo } \\
\text { Não }\end{array}$ & $\begin{array}{l}\text { Nao } \\
\text { Não }\end{array}$ & $\begin{array}{l}\text { Nao } \\
\text { Não }\end{array}$ & $\begin{array}{l}\text { Nao } \\
\text { Não }\end{array}$ & $\begin{array}{l}\text { Nao } \\
\text { Năo }\end{array}$ & Sim & 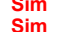 & $\begin{array}{l}1280 \\
1280\end{array}$ & 1997 & Sim & $\begin{array}{l}\text { Nao } \\
\text { Não }\end{array}$ & $\begin{array}{l}1,1 \\
1,1\end{array}$ & $\begin{array}{l}\text { Nao } \\
\text { Não }\end{array}$ & $\begin{array}{l}\text { Nao } \\
\text { Năo }\end{array}$ & & & 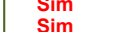 & $\mathrm{Sim}$ & 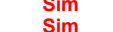 & $\mathrm{Sim}$ & Sim & Sim & Sim \\
\hline 86 & mai-14 & Osasco & Não & Não & Não & Não & Não & Não & sim & 1280 & 1997 & Sim & Não & $\begin{array}{l}1,1 \\
1.1\end{array}$ & Não & Não & & & Nā̃o & 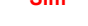 & sim & Sim & $\mathrm{SIm}$ & Sim & \\
\hline $\begin{array}{l}87 \\
87\end{array}$ & out-14 & Osasco & Não & Não & Não & Não & Não & Não & sim & 1280 & 1997 & sim & Não & 11 & Não & Não & & & กล้อ & & sim & Sim & & & \\
\hline 88 & jun-15|O & Osasco & Não & Não & Não & Não & Não & Não & Sim & 1280 & 1997 & Sim & Não & 1,1 & Não & Não & & & Não & & Sim & Sim & & & \\
\hline 89 & out-15 & Osasco & Não & Não & Não & Não & Não & Não & Sim & 1280 & 1997 & Sim & Não & 1,1 & Não & Não & & & Não & & Sim & Sim & & & \\
\hline 90 & nov-07 & Cubatão & Não & Não & Não & Não & Não & Sim & Não & 9000 & 2004 & Sim & Não & 1,0 & Não & Não & Sim & & Sim & Sim & Não & & Sim & Sim & Não \\
\hline 91 & jan-08 $C$ & Cubatão & Não & Sim & Não & Não & Não & Não & Não & 9000 & 2004 & Sim & Não & 1,0 & Não & Não & Não & & Não & & Não & & Não & Não & \\
\hline 92 & $\begin{array}{ll}\text { ago-08 } & \mathrm{C} \\
\end{array}$ & Cubatão & Não & Não & Sim & Sim & Não & Não & Não & 9000 & 2004 & Sim & Não & 1,0 & Não & Não & Sim & Sim & Sim & Sim & Sim & Sim & Não & Não & \\
\hline 93 & mar-12 & Cubatão & Não & Não & Não & Não & Não & Não & Sim & 9000 & 2004 & Sim & Não & 1,0 & Não & Não & Não & Não & Sim & $\operatorname{Sim}$ & Sim & Sim & Não & Não & \\
\hline 94 & ago-12 C & Cubatão & Não & Não & Não & Não & Não & Não & Sim & 9000 & 2004 & Sim & Não & 1,0 & Não & Não & Não & Não & Sim & Sim & Sim & Sim & Não & Não & \\
\hline 95 & $\begin{array}{l}\text { jan-14 } \\
\text { fev-14 }\end{array}$ & $\begin{array}{l}\text { Cubatão } \\
\text { Cubatão }\end{array}$ & $\begin{array}{l}\text { Não } \\
\text { Nã }\end{array}$ & $\begin{array}{l}\text { Não } \\
\text { Não }\end{array}$ & $\begin{array}{l}\text { Não } \\
\text { Não }\end{array}$ & $\begin{array}{l}\text { Não } \\
\text { Năo }\end{array}$ & $\begin{array}{l}\text { Sim } \\
\text { Sim }\end{array}$ & Sim & $\begin{array}{l}\text { Não } \\
\text { Nẫo }\end{array}$ & $\begin{array}{l}9000 \\
9000\end{array}$ & $\begin{array}{l}2004 \\
2004\end{array}$ & $\begin{array}{l}\text { Sim } \\
\text { Sim }\end{array}$ & $\begin{array}{l}\text { Não } \\
\text { Não }\end{array}$ & $\begin{array}{l}1,0 \\
10\end{array}$ & $\begin{array}{l}\text { Não } \\
\text { Simm }\end{array}$ & Não & Sim & Sim & Sim & Sim & Sim & Sim & Sim & Sim & \\
\hline $\begin{array}{l}96 \\
97\end{array}$ & 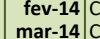 & $\begin{array}{l}\text { Cubatão } \\
\text { Cubatãõo }\end{array}$ & $\begin{array}{l}\text { Não } \\
\text { Não }\end{array}$ & $\begin{array}{l}\text { Não } \\
\text { Não }\end{array}$ & $\begin{array}{l}\text { Não } \\
\text { Não }\end{array}$ & 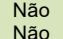 & $\begin{array}{l}\text { Sim } \\
\text { Não }\end{array}$ & $\begin{array}{l}\text { Sim } \\
\text { Năo }\end{array}$ & $\begin{array}{l}\text { Não } \\
\text { Sim }\end{array}$ & $\begin{array}{l}9000 \\
9000\end{array}$ & $\begin{array}{l}2004 \\
2004\end{array}$ & $\begin{array}{l}\text { Sim } \\
\text { Sim }\end{array}$ & $\begin{array}{l}\text { Não } \\
\text { Năo }\end{array}$ & $\begin{array}{l}1,0 \\
1,0\end{array}$ & $\begin{array}{l}\text { Sim } \\
\text { Sim }\end{array}$ & $\begin{array}{l}\text { Sim } \\
\text { Sim }\end{array}$ & $\begin{array}{l}\text { Sim } \\
\text { Não }\end{array}$ & $\begin{array}{l}\text { Sim } \\
\text { Não }\end{array}$ & $\begin{array}{l}\text { Sim } \\
\text { Năo }\end{array}$ & $\begin{array}{l}\text { Sim } \\
\text { Não }\end{array}$ & $\begin{array}{l}\text { Sim } \\
\text { Sim }\end{array}$ & $\begin{array}{l}\text { Sim } \\
\text { Não }\end{array}$ & $\begin{array}{l}\text { Sim } \\
\text { Não }\end{array}$ & Sim & \\
\hline $\begin{array}{l}97 \\
98\end{array}$ & $\begin{array}{c}\text { mar-14 } \\
\text { ago-14 }\end{array}$ & $\begin{array}{l}\text { Cubataoo } \\
\text { Cubatão }\end{array}$ & $\begin{array}{l}\text { Naoo } \\
\text { Não }\end{array}$ & $\begin{array}{l}\text { Nâo } \\
\text { Nâo }\end{array}$ & $\begin{array}{l}\text { Náo } \\
\text { Sim }\end{array}$ & $\begin{array}{l}\text { Nâo } \\
\text { Nâo }\end{array}$ & $\begin{array}{l}\text { Não } \\
\text { Não }\end{array}$ & $\begin{array}{l}\text { Năo } \\
\text { Não }\end{array}$ & $\begin{array}{l}\text { Sim } \\
\text { Não }\end{array}$ & $\begin{array}{l}9000 \\
9000\end{array}$ & $\begin{array}{l}2004 \\
2004\end{array}$ & $\begin{array}{l}\text { Sim } \\
\text { Sim }\end{array}$ & $\begin{array}{l}\text { Não } \\
\text { Não }\end{array}$ & $\begin{array}{l}1,0 \\
1,0\end{array}$ & $\begin{array}{l}\text { Sim } \\
\text { Sim }\end{array}$ & $\begin{array}{l}\text { Sim } \\
\text { Sim }\end{array}$ & $\begin{array}{l}\text { Não } \\
\text { Não }\end{array}$ & $\begin{array}{l}\text { Não } \\
\text { Não }\end{array}$ & $\begin{array}{l}\text { Não } \\
\text { Não }\end{array}$ & $\begin{array}{l}\text { Não } \\
\text { Não }\end{array}$ & $\begin{array}{l}\text { Sim } \\
\text { Sim }\end{array}$ & $\begin{array}{l}\text { Nâo } \\
\text { Sim }\end{array}$ & $\begin{array}{l}\text { Não } \\
\text { Não }\end{array}$ & & \\
\hline $\begin{array}{l}98 \\
99\end{array}$ & nov-14 & Cubatão & $\begin{array}{l}\text { Noo } \\
\text { Não }\end{array}$ & $\begin{array}{l}\text { Nao } \\
\text { Não }\end{array}$ & $\begin{array}{l}\text { Sim } \\
\text { Não }\end{array}$ & $\begin{array}{l}\text { Nao } \\
\text { Não }\end{array}$ & $\begin{array}{l}\text { Nao } \\
\text { Não }\end{array}$ & $\begin{array}{l}\text { Nao } \\
\text { Não }\end{array}$ & $\begin{array}{l}\text { Nao } \\
\text { Sim }\end{array}$ & 9000 & 2004 & sim & Não & $\begin{array}{l}1,0 \\
1,0\end{array}$ & Sim & Sim & & & Não & Não & $\mathrm{Sim}$ & $\mathrm{Sim}$ & & & \\
\hline 100 & dez-15 C & Cubatão & Nă & Năo & กล้อ & Não & Não & Năo & Sim & 9000 & 2004 & Sim & Não & 10 & sim & Sim & & & Năo & Não & Sim & Sim & & & \\
\hline 101 & mai-16 & Cubatão & Não & Não & Não & Não & Não & Não & Sim & 9000 & 2004 & Sim & Não & $\begin{array}{l}1,0 \\
1,0\end{array}$ & Sim & $\mathrm{Sim}$ & & & Não & Não & $\mathrm{Sim}$ & $\mathrm{Sim}$ & & & \\
\hline 102 & abr-07 L & Limeira & Não & Sim & Não & Não & Não & Não & Não & 916 & 1979 & Não & Sim & 10,0 & Sim & Não & Sim & Não & Não & Não & Sim & Não & & & \\
\hline 103 & 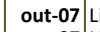 & Limeira & Não & Não & Sim & Sim & Não & Não & Não & 916 & 1979 & Não & $\mathrm{Sim}$ & 10,0 & sim & Não & Sim & Não & Não & Não & sim & Não & & & \\
\hline 104 & nov-07 $\mid$ L & Limeira & Não & Não & Não & Não & Não & Sim & Não & 916 & 1979 & Não & Sim & 10,0 & Não & Não & Não & Não & Não & Não & Sim & Sim & Sim & & \\
\hline 105 & abr-08 $L$ & Limeira & Não & Não & Não & Não & Não & Não & Sim & 916 & 1979 & Não & Sim & 10,0 & Não & Não & Não & Não & Não & Não & Sim & Não & & & \\
\hline 106 & jul-08 $L$ & Limeira & Não & Não & Não & Não & Não & Não & Sim & 916 & 1979 & Não & Sim & 10,0 & Não & Não & Não & Não & Não & Não & Sim & Sim & & & \\
\hline 107 & $\operatorname{dez}-08 \mid L$ & Limeira & & Não & Não & Não & Não & Não & Sim & 916 & 1979 & Não & Sim & 10,0 & Não & Não & Não & Não & Não & Não & Sim & Sim & & & \\
\hline 108 & jun-09 L $L$ & Limeira & Não & Não & Não & Não & Não & Não & Sim & 916 & 1979 & Não & Sim & 10,0 & Sim & Não & Não & Não & Sim & Sim & Sim & Sim & & & \\
\hline 109 & dez-09 L & Limeira & Não & Não & Não & Não & Não & Não & Sim & 916 & 1979 & Não & Sim & 10,0 & sim & Não & Não & Não & Sim & Sim & Sim & Sim & & & \\
\hline 110 & jun-09 L L & Limeira & Não & Não & Não & Não & Não & Sim & Não & 916 & 1979 & Não & Sim & 10,0 & & & Não & Não & Sim & Sim & Sim & Sim & Sim & Não & Sim \\
\hline 111 & ago-09 L L & Limeira & Não & Não & Não & Não & Não & Sim & Não & 916 & 1979 & Não & Sim & 10,0 & & & Não & Não & Sim & Sim & Sim & Sim & Sim & Não & Sim \\
\hline 112 & nov-09 L & Limeira & Não & Não & Não & Não & Não & Sim & Não & 916 & 1979 & Não & Sim & 10,0 & & & Não & Não & Sim & Sim & Sim & Sim & Sim & Não & Sim \\
\hline 113 & fev-10 L & Limeira & Não & Não & Não & Não & Não & Sim & Não & 916 & 1979 & Não & Sim & 10,0 & & & Não & Não & Sim & Sim & Sim & Sim & Sim & Não & Sim \\
\hline 114 & mai-10 L & Limeira & Nã & Não & Não & Não & Não & Sim & & & & Não & $\sin$ & 10, & & & Não & Nã & Sim & & & & Sim & Não & Sim \\
\hline 115 & dez-10 & Limeira & Não & Não & Sim & Sim & Sim & Sim & Não & 916 & 1979 & Não & $\mathrm{Sim}$ & 10,0 & Sim & Não & Não & Não & Sim & Sim & sim & Sim & Sim & Não & Sim \\
\hline 116 & jan-11 L L & Limeira & Não & Não & Não & Não & Não & Sim & Não & 916 & 1979 & Não & Sim & 10,0 & & & Não & Não & Sim & Sim & Sim & Sim & Sim & Não & Sim \\
\hline 117 & mai-11 LL & Limeira & Não & Não & Não & Não & Não & Sim & Não & 916 & 19 & Não & Sim & 10,0 & & & Não & Não & Sim & Sim & Sim & Sim & Sim & Não & Sim \\
\hline 118 & jul & Limeira & Não & Não & Não & Não & Não & Sim & Sim & 91 & 19 & Não & Sim & 10,0 & Não & Não & Não & Não & & & Sim & im & & & \\
\hline 119 & nov-11 & Limeira & Não & Não & Não & Não & Não & Sim & Sim & 91 & 19 & Não & Sim & 10,0 & & & Não & Não & Não & Não & Sim & Sim & & & \\
\hline 120 & mai-12 & Limeira & Não & Não & Não & Não & Não & Sim & Não & 916 & $\begin{array}{l}1979 \\
1079\end{array}$ & Não & Sim & 10,0 & & & Não & Não & Não & Não & Sim & Não & Sim & Não & sim \\
\hline 121 & set-12 & Limeira & Não & Não & Não & Não & Não & Não & Sim & 916 & $\begin{array}{l}1979 \\
1070\end{array}$ & Não & Sim & 10,0 & & & Não & Não & Não & Não & Sim & Sim & & Não & Não \\
\hline 122 & mar-13 & Limeira & Não & Não & Não & Não & Não & Não & Sim & & & Não & Sim & 10,0 & & & Não & Não & Não & Não & Sim & Sim & & & Não \\
\hline 123 & mai-16 $\mid L$ & Limeira & Nầ & Não & Não & Não & Não & Nầ & Sim & 91 & 1979 & Não & Sim & 10,0 & Não & Não & Não & Não & Não & Não & Sim & Sim & & & \\
\hline 124 & dez-16 $L$ & Limeira & Não & Não & Não & Não & Não & Não & Sim & 916 & 19 & Não & Sim & 10,0 & Não & Não & Não & Não & Não & Não & $\mathrm{Sim}$ & $\mathrm{Sim}$ & & & \\
\hline 125 & nov-09 S & São Paulo & Não & Não & Sim & sim & Não & $\mathrm{Nã}$ & $\mathrm{N}$ & 917 & 19 & Sir & Nã & 4,0 & & & & & & & & & & & \\
\hline 126 & out-12 $\mathrm{S}$ & São Paulo & Nầ & Não & Não & Não & Sim & Nầ & $\mathrm{N}$ & 917 & 19 & $\mathrm{Si}$ & Nãa & 4,0 & & & & & & & Sim & Sim & & & \\
\hline 127 & jan-13 $\mathrm{S}$ & São Pau & Não & Não & Não & Não & Não & Sim & & & 19 & Sim & $\mathrm{N}$ & 4,0 & & & & & & & Si & & & & \\
\hline 128 & mar-13 $\mathrm{s}$ & São Paulo & Não & Não & Não & Não & Não & Sim & Não & 917 & 1970 & Sim & Não & 4,0 & & & & & & & sim & Sim & & & \\
\hline 129 & mai-13 $\mathrm{s}$ & São Paulo & Não & Não & Não & Não & Não & Sim & Não & 917 & 1970 & Sim & Não & 4,0 & & & & & & & Sim & Sim & & & \\
\hline 130 & ago & São Paulo & Não & Não & Sim & Não & Nã & Não & $N$ & 91 & 19 & Sim & Nầ & 4,0 & & & & & & & Sim & Sim & & & \\
\hline 131 & $13 \mathrm{~S}$ & São Paulo & Não & Não & Não & Não & Sim & Não & $\mathrm{N}$ & 917 & 197 & Sir & Não & 4,0 & & & & & & & Sim & Sim & & & \\
\hline 132 & dez-13 & Săo Paulo & Não & Não & Não & Não & Não & Sim & Não & 917 & 1970 & Sim & Não & 4,0 & & & & & & & Sim & Sim & & & \\
\hline 133 & mar-14 & São Paulo & Não & Não & Sim & Não & Não & Não & Não & 917 & $\begin{array}{l}1970 \\
1970\end{array}$ & Sim & Não & 4,0 & & & & & & & Sim & Sim & & & \\
\hline 134 & mai-14 & $\begin{array}{l}\text { São Paulo } \\
\text { São Paulo }\end{array}$ & Não & $\begin{array}{l}\text { Não } \\
\text { Não }\end{array}$ & $\begin{array}{l}\text { Não } \\
\text { Nẫo }\end{array}$ & Não & $\begin{array}{l}\text { Não } \\
\text { Nân }\end{array}$ & Não & $\begin{array}{l}\text { Sim } \\
\text { Não }\end{array}$ & $\begin{array}{l}917 \\
917\end{array}$ & $\begin{array}{l}1970 \\
1970\end{array}$ & Sim & $\begin{array}{l}\text { Não } \\
\text { Não }\end{array}$ & $\begin{array}{l}4,0 \\
40\end{array}$ & & & & & & & Sim & Sim & & & \\
\hline 136 & $\mid \begin{array}{l}\text { ago-14 } \\
\text { fev-15 }\end{array}$ & $\begin{array}{l}\text { São Paulo } \\
\text { Saulo }\end{array}$ & $\begin{array}{l}\text { Nao } \\
\text { Não }\end{array}$ & $\begin{array}{l}\text { Nao } \\
\text { Não }\end{array}$ & $\begin{array}{l}\text { Nao } \\
\text { Não }\end{array}$ & $\begin{array}{l}\text { Nao } \\
\text { Não }\end{array}$ & $\begin{array}{l}\text { Nao } \\
\text { Não }\end{array}$ & $\begin{array}{l}\text { Sim } \\
\text { Não }\end{array}$ & $\begin{array}{l}\text { Nao } \\
\text { Sim }\end{array}$ & $\begin{array}{l}917 \\
917\end{array}$ & 1970 & Sim & $\begin{array}{l}\text { Nao } \\
\text { Não }\end{array}$ & $\begin{array}{l}4,0 \\
4,0\end{array}$ & & & & & & & Sim & Sim & & & \\
\hline
\end{tabular}




\begin{tabular}{|c|c|c|c|c|c|c|c|c|c|c|c|c|c|c|c|c|c|c|c|c|c|c|c|c|c|}
\hline \multirow[b]{2}{*}{ ID } & \multirow[b]{2}{*}{$\begin{array}{c}\text { Data } \\
\text { Registro }\end{array}$} & IDENTIFICAÇĀO & & & RENC & ONAM & A / CET & ESB & & DADOS & O POSTO & & exto geoló & gico & FASE & VAPOR & FASE & ETIDA & LNA & & Dis: & olv & & & \\
\hline & & Cidade & AvP & IC & ID & Artx & PI & REM & ME & $\begin{array}{c}\text { Área } \\
\mathrm{m} 2\end{array}$ & $\begin{array}{l}\text { Data } \\
\text { instala }\end{array}$ & Sed. & $\begin{array}{l}\text { Rocha } \\
\text { alterada }\end{array}$ & $\begin{array}{c}\text { ZN Sat } \\
(\mathrm{m})\end{array} \mid$ & $\begin{array}{c}\text { Detectado } \\
? ?\end{array}$ & $\begin{array}{c}\text { Delimitado } \\
?\end{array}$ & $\begin{array}{c}\text { Detectado } \\
?\end{array}$ & $\begin{array}{c}\text { Delimitado } \\
?\end{array}$ & $\left.\mid \begin{array}{c}\text { Detectado } \\
?\end{array}\right] ?$ & Delimit & $\begin{array}{c}\text { Detectado } \\
?\end{array}$ & $\begin{array}{c}\text { Delimitada } \\
?\end{array}$ & $\begin{array}{c}\text { Remediação } \\
?\end{array}$ & $\begin{array}{c}\text { Remediação } \\
\text { Z Nsatu? }\end{array}$ & $\begin{array}{l}\text { Remediaçã } \\
\text { Z Sat? }\end{array}$ \\
\hline 137 & & São Paulo & Não & Não & Não & Não & Não & Sim & Não & 917 & 1970 & Sim & Não & 4,0 & & & & & & & Sim & Sim & & & \\
\hline 138 & jun-15 & São Paulo & Não & Não & Não & Não & Não & Não & Sim & 917 & 1970 & sim & Não & 4,0 & & & & & & & Sim & Sim & & & \\
\hline 139 & ago-15 & São Paulo & Não & Não & sim & Não & Não & Não & sim & 917 & 1970 & Sim & Não & 4,0 & & & & & & & sim & Sim & & & \\
\hline 140 & nov-15 & São Paulo & Não & Não & Não & Não & Não & Não & sim & 917 & 1970 & Sim & Não & 4,0 & & & & & & & & Sim & & & \\
\hline 141 & out-99 & São Paulo & Sim & Sim & Não & Não & Não & Não & Não & 1135 & 1973 & Sim & Não & 1,8 & & & & & & & & & & & \\
\hline 142 & & São Paulo & Não & Não & Sim & Sim & Não & Não & Não & 1135 & 1973 & Sim & Não & 1,8 & Sim & Não & Sim & Não & Sim & Não & Sim & Não & & & \\
\hline 143 & out-02 & São Paulo & Não & Não & Sim & Sim & Não & Não & Não & 1135 & 1973 & Sim & Não & 1,8 & Sim & Não & Sim & Não & $\mathrm{Sim}$ & Sim & Sim & Não & Sim & Sim & Não \\
\hline 144 & mai-05 & São Paulo & Não & Não & Sim & Sim & Não & Não & Não & 1135 & 1973 & sim & Não & 1,8 & sim & Não & Sim & Não & Não & Não & Sim & $\mathrm{Sim}$ & & & 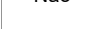 \\
\hline 145 & mar-06 & São Paulo & Não & Não & Sim & sim & Não & Não & Não & 1135 & 1973 & Sim & Não & 1,8 & sim & Não & Sim & Não & Não & Não & sim & Sim & & & \\
\hline 146 & fev-07 & São Paulo & Não & Não & Sim & Sim & sim & Sim & Não & 1135 & 1974 & Sim & Não & 1,8 & Sim & Não & Sim & Não & Sim & Sim & Sim & Sim & Sim & Não & Sim \\
\hline 147 & mai-07| & Săo Paulo & Não & Não & Não & Não & Não & Sim & Não & 1135 & 1975 & Sim & Não & 1,8 & Sim & Não & Sim & Não & Sim & Sim & Sim & Sim & Sim & Não & Sim \\
\hline 148 & & Săo Paulo & Não & Não & Não & Não & Não & Sim & Não & 1135 & 1976 & Sim & Não & 1,8 & & Não & Sim & Não & Sim & Sim & Sim & Sim & Sim & Não & \\
\hline 149 & jun-07 & São Paulo & Não & Não & Não & Não & Não & Sim & Não & 1135 & 1973 & Sim & Não & 1,8 & sim & Não & Sim & Não & Sim & Sim & Sim & sim & Sim & Não & Sim \\
\hline 150 & ago-07 & São Paulo & Não & Não & Sim & Sim & Não & Não & Não & 1135 & 1973 & Sim & Não & 1,8 & Não & Não & Não & Não & Sim & Sim & Sim & Sim & & & \\
\hline 151 & mai-08 & São Paulo & Não & Não & Não & Não & Não & Não & Sim & 1135 & 1973 & Sim & Não & 1,8 & & & & & Não & Não & $\mathrm{Sim}$ & $\mathrm{Sim}$ & & & \\
\hline 152 & nov-08 & São Paulo & Não & Não & Não & Não & Não & Não & Sim & 1135 & 1973 & Sim & Não & 1,8 & Não & Não & Não & Não & Não & Não & Sim & Sim & & & \\
\hline 153 & jun-09 & Săo Paulo & Não & Não & Não & Não & Não & Não & Sim & 1135 & 1973 & Sim & Não & 1,8 & Não & Não & Não & Não & Não & Não & Sim & Sim & & & \\
\hline & dez-09 & São Paulo & Não & Não & Não & Não & Não & Não & & 1135 & 1973 & Sim & Não & 1,8 & Não & Não & Não & Não & Não & Não & Sim & Sim & & & \\
\hline 155 & ago-10 & São Paulo & Não & Não & Sim & Não & Sim & Não & Não & 1135 & 1973 & Sim & Não & 1,8 & Não & Não & Não & Não & Não & Não & Sim & & & & \\
\hline 156 & out-10 & São Paulo & Não & Não & Não & Não & Não & Sim & Não & 1135 & 1973 & Sim & Não & 1,8 & Não & Não & Não & Não & Não & Não & Sim & Sim & Sim & Sim & Sim \\
\hline 157 & dez-10 & São Paulo & Não & Não & Não & Não & Não & $\operatorname{sim}$ & Não & 1135 & 1973 & Sim & Não & 1,8 & Não & Não & Não & Não & Não & Não & $\mathrm{Sim}$ & $\mathrm{Sim}$ & $\mathrm{Sim}$ & Sim & sim \\
\hline 158 & fev-12 & São Paulo & Não & Não & Não & Não & Não & Não & Sim & 1135 & 1973 & Sim & Não & 1,8 & Não & Não & Não & Não & Não & Não & Sim & Sim & & & \\
\hline 159 & abr-12 & São Paulo & Não & Não & Não & Não & Não & Não & Sim & 1135 & 1973 & Sim & Não & 1,8 & Não & Não & Não & Não & Não & Não & Sim & Sim & & & \\
\hline 160 & jun-12 & São Paulo & Não & Não & Não & Não & Não & Sim & Sim & 1135 & 1973 & Sim & Não & 1,8 & Não & Não & Não & Não & Não & Não & Sim & Sim & Sim & Sim & \\
\hline 161 & ago-12 & São Paulo & Não & Não & Não & Não & Não & Não & sim & 1135 & 1973 & Sim & Não & 1,8 & Não & Não & Não & Não & Não & Não & Sim & Sim & & & \\
\hline 162 & fev-13 & São Paulo & & Não & Não & Não & Não & Sim & Não & 1135 & 1973 & Sim & Não & 1,8 & & & & & & & & & Sim & Não & Sim \\
\hline 163 & mar-13 & São Paulo & Não & Não & Não & Não & Não & Não & Sim & 1135 & 1973 & Sim & Não & 1,8 & & & & & & & Sim & Sim & . & Nav & . \\
\hline 164 & jun-00 & São Paulo & Sim & Sim & Não & Sim & Não & Não & Não & 450 & 1970 & Sim & Não & 4,0 & & & & & & & & & & & \\
\hline 165 & jun-01 & São Paulo & Não & Não & Sim & Não & Não & Não & Não & 450 & 1970 & Sim & Não & 4,0 & & & & & & & & & & & \\
\hline 166 & abr-03 & São Paulo & Não & Não & Não & Não & Sim & Não & Não & 450 & 1970 & Sim & Não & 4,0 & Sim & Sim & Sim & Sim & Não & Não & & & & & \\
\hline 167 & jul-03 & São Paulo & Não & Não & Não & Não & sim & Sim & Não & 450 & 1970 & Sim & Não & 4,0 & sim & $\mathrm{Sim}$ & Sim & $\mathrm{Sim}$ & Não & Não & & & & & \\
\hline 168 & dez-03 & São Paulo & Não & Não & Não & Não & Não & $\mathrm{Sim}$ & Não & 450 & 1970 & Sim & Não & 4,0 & Sim & Sim & Sim & $\mathrm{Sim}$ & Não & Não & Sim & Sim & Sim & Sim & sim \\
\hline 169 & jan-04 & São Paulo & Não & Não & Não & Não & Não & Sim & Não & 450 & 1970 & Sim & Não & 4,0 & Sim & Sim & Sim & $\mathrm{Sim}$ & Não & Não & Sim & Sim & Sim & Sim & \\
\hline 170 & mar-04 & São Paulo & Não & Não & Não & Não & Não & Sim & Não & 450 & 1970 & Sim & Não & 4,0 & Sim & Sim & Sim & Sim & Não & Não & Sim & Sim & Sim & Sim & \\
\hline 171 & mai-04 & São Paulo & Não & Não & Não & Não & Não & Sim & Não & 450 & 1970 & Sim & Não & 4,0 & Sim & Sim & Sim & Sim & Não & Não & Sim & Sim & Sim & Sim & \\
\hline 172 & jul-04 & São Paulo & Não & Não & Não & Não & Não & Sim & Não & 450 & 1970 & Sim & Não & 4,0 & Sim & Sim & Sim & Sim & Não & Não & Sim & Sim & Sim & Sim & \\
\hline 173 & set- 04 & São Paulo & Não & Não & Não & Não & Não & Sim & Não & 450 & 1970 & Sim & Não & 4,0 & Sim & Sim & Sim & Sim & Não & Não & Sim & Sim & Sim & Sim & \\
\hline 174 & nov-04 & São Paulo & Não & Não & Não & Não & Não & $\mathrm{Sim}$ & Não & 450 & 1970 & Sim & Não & 4,0 & Sim & $\mathrm{Sim}$ & Sim & $\mathrm{Sim}$ & Não & Não & $\mathrm{Sim}$ & Sim & $\mathrm{Sim}$ & Sim & \\
\hline 175 & jan-05 & São Paulo & Não & Não & Não & Não & Não & Sim & Não & 450 & 1970 & Sim & Não & 4,0 & Sim & Sim & Sim & Sim & Não & Não & Sim & Sim & Sim & Sim & \\
\hline 176 & mar-05 & São Paulo & Não & Não & Não & Não & Não & Sim & Não & 450 & 1970 & sim & Não & 4,0 & sim & Sim & sim & sim & Não & Não & sim & Sim & sim & sim & \\
\hline 177 & mai-05 & São Paulo & Não & Não & Não & Não & Não & Sim & Não & 450 & 1970 & Sim & Não & 4,0 & sim & sim & Sim & Sim & Não & Não & Sim & Sim & sim & sim & \\
\hline 178 & jul-05 & São Paulo & Não & Não & Não & Não & Não & Sim & Não & 450 & 1970 & Sim & Não & 4,0 & Sim & Sim & Sim & Sim & Não & Não & Sim & Sim & Sim & Sim & \\
\hline 179 & set-05 & São Paulo & Não & Não & Não & Não & Não & Sim & Não & 450 & 1970 & Sim & Não & 4,0 & Sim & Sim & Sim & Sim & Não & Não & Sim & Sim & Sim & Sim & \\
\hline 180 & nov-05 & São Paulo & Não & Não & Não & Não & Não & Sim & Não & 450 & 1970 & Sim & Não & 4,0 & Sim & Sim & Sim & Sim & & Não & Sim & Sim & Sim & Sim & \\
\hline 181 & jan-06 & São Paulo & Não & Não & Não & Não & Não & Sim & Não & 450 & 197 & Sim & Não & 4,0 & Sim & Sim & Sim & Sim & Não & Não & sim & Sim & sim & Sim & \\
\hline 182 & jun-06 & São Paulo & Não & Não & Não & Não & Não & Sim & Não & 450 & 1970 & Sim & Não & 4,0 & sim & Sim & Sim & Sim & Não & Não & Sim & Sim & sim & Sim & \\
\hline 183 & fev-07 & São Paulo & Não & Não & Não & Não & Não & Sim & Não & 450 & 1970 & Sim & Não & 4,0 & sim & Sim & Não & Não & & & Sim & & & & \\
\hline 184 & mar-07 & São Paulo & Não & Não & Não & Não & Não & Sim & Não & 450 & 197 & Sim & Não & 4,0 & Sim & Sim & Não & Não & & & Sim & & & & \\
\hline 185 & abr-07 & São Paulo & Não & Não & Não & Não & Não & Sim & Não & 45 & 19 & Sim & Não & 4,0 & Sim & Sim & Não & Não & & & Sim & & & & \\
\hline 186 & mai-07 & São Paulo & Não & Não & Não & Não & Não & Sim & Não & 450 & $\begin{array}{l}1970 \\
1970\end{array}$ & Sim & Não & 4,0 & Sim & Sim & Não & Não & & & Sim & & & & \\
\hline $\begin{array}{l}187 \\
188\end{array}$ & $\begin{array}{r}\text { jun-07 } \\
\text { jul-07 }\end{array}$ & $\begin{array}{l}\begin{array}{l}\text { São Paulo } \\
\text { São Paulo }\end{array}\end{array}$ & $\begin{array}{l}\text { Não } \\
\text { Não }\end{array}$ & $\begin{array}{l}\text { Não } \\
\text { Não }\end{array}$ & $\begin{array}{l}\text { Não } \\
\text { Não }\end{array}$ & $\begin{array}{l}\text { Não } \\
\text { Năo }\end{array}$ & $\begin{array}{l}\text { Não } \\
\text { Năo }\end{array}$ & Sim & $\begin{array}{l}\text { Não } \\
\text { Năo }\end{array}$ & $\begin{array}{l}\begin{array}{r}450 \\
450\end{array} \\
4\end{array}$ & $\begin{array}{l}1970 \\
1970\end{array}$ & $\begin{array}{l}\text { Sim } \\
\text { Sim }\end{array}$ & $\begin{array}{l}\text { Não } \\
\text { Não }\end{array}$ & $\begin{array}{l}4,0 \\
40\end{array}$ & Sim & Sim & Não & Não & & & Sim & & & & \\
\hline $\begin{array}{l}188 \\
189\end{array}$ & $\begin{array}{r}\text { jul-07 } \\
\text { ago-07 }\end{array}$ & $\begin{array}{l}\begin{array}{l}\text { Sao Paulo } \\
\text { São Paulo }\end{array} \\
\text { lalo }\end{array}$ & $\begin{array}{l}\text { Não } \\
\text { Não }\end{array}$ & $\begin{array}{l}\text { Não } \\
\text { Não }\end{array}$ & $\begin{array}{l}\text { Não } \\
\text { Não }\end{array}$ & $\begin{array}{l}\begin{array}{l}\text { Não } \\
\text { Nâo }\end{array} \\
\text { a }\end{array}$ & $\begin{array}{l}\begin{array}{l}\text { Não } \\
\text { Não }\end{array}\end{array}$ & $\begin{array}{l}\text { Sim } \\
\text { Sim }\end{array}$ & $\begin{array}{l}\begin{array}{l}\text { Não } \\
\text { Nâo }\end{array}\end{array}$ & $\begin{array}{l}\begin{array}{r}450 \\
450\end{array} \\
4\end{array}$ & $\begin{array}{l}1970 \\
1970\end{array}$ & $\begin{array}{l}\text { Sim } \\
\text { Sim }\end{array}$ & $\begin{array}{l}\text { Não } \\
\text { Não }\end{array}$ & $\begin{array}{l}4,0 \\
4,0\end{array}$ & Sim & $\begin{array}{l}\text { Sim } \\
\text { Sim }\end{array}$ & $\begin{array}{l}\text { Não } \\
\text { Não }\end{array}$ & $\begin{array}{l}\text { Não } \\
\text { Não }\end{array}$ & & & $\begin{array}{l}\text { Sim } \\
\text { Sim }\end{array}$ & & & & \\
\hline $\begin{array}{l}189 \\
190\end{array}$ & $\begin{array}{c}\text { ago-07 } \\
\text { set-07 }\end{array}$ & $\begin{array}{l}\text { Sao Paulo } \\
\text { São Paulo }\end{array}$ & $\begin{array}{l}\text { Nẫo } \\
\text { Não }\end{array}$ & $\begin{array}{l}\text { Não } \\
\text { Não }\end{array}$ & $\begin{array}{l}\text { Não } \\
\text { Não }\end{array}$ & $\begin{array}{l}\begin{array}{l}\text { Não } \\
\text { Nâo }\end{array}\end{array}$ & $\begin{array}{l}\text { Não } \\
\text { Não }\end{array}$ & $\begin{array}{l}\text { Sim } \\
\text { Sim }\end{array}$ & $\begin{array}{l}\begin{array}{l}\text { Não } \\
\text { Nâo }\end{array}\end{array}$ & $\begin{array}{l}450 \\
450\end{array}$ & $\begin{array}{l}19 / 0 \\
1970\end{array}$ & $\begin{array}{l}\text { Sim } \\
\text { Sim }\end{array}$ & $\begin{array}{l}\text { Não } \\
\text { Não }\end{array}$ & $\begin{array}{l}4,0 \\
4,0\end{array}$ & $\begin{array}{l}\text { Sim } \\
\text { Sim }\end{array}$ & $\begin{array}{l}\text { Sim } \\
\text { Sim }\end{array}$ & $\begin{array}{l}\text { Não } \\
\text { Não }\end{array}$ & $\begin{array}{l}\text { Não } \\
\text { Não }\end{array}$ & & & $\begin{array}{l}\text { Sim } \\
\text { Sim }\end{array}$ & & & & \\
\hline 191 & $\begin{array}{l}\text { set-0u } \\
\text { out-07 }\end{array}$ & $\begin{array}{l}\text { São Paulo } \\
\text { Sâlo }\end{array}$ & $\begin{array}{l}\text { Nao } \\
\text { Não }\end{array}$ & $\begin{array}{l}\text { Nao } \\
\text { Não }\end{array}$ & $\begin{array}{l}\text { Nao } \\
\text { Não }\end{array}$ & $\begin{array}{l}\text { Nao } \\
\text { Não }\end{array}$ & $\begin{array}{l}\text { Nao } \\
\text { Não }\end{array}$ & $\begin{array}{l}\text { Sim } \\
\text { Sim }\end{array}$ & $\begin{array}{l}\text { Nao } \\
\text { Nâo }\end{array}$ & $\begin{array}{l}450 \\
450\end{array}$ & 1970 & $\begin{array}{l}\text { Sim } \\
\text { Sim }\end{array}$ & $\begin{array}{l}\text { Nao } \\
\text { Não }\end{array}$ & $\begin{array}{l}\begin{array}{l}4,0 \\
4,0\end{array}\end{array}$ & Sim & Sim & $\begin{array}{l}\text { Nao } \\
\text { Não }\end{array}$ & $\begin{array}{l}\text { Nao } \\
\text { Não }\end{array}$ & & & Sim & & & & \\
\hline 192 & nov-07 & São Paulo & Não & Não & Não & Não & Não & Sim & Não & 450 & 1970 & Sim & Não & 4,0 & Sim & Sim & $\begin{array}{l}\text { Nao } \\
\text { Não }\end{array}$ & $\begin{array}{l}\text { Nao } \\
\text { Não }\end{array}$ & & & Sim & & & & \\
\hline 193 & dez-07 & São Paulo & Não & Não & Não & Não & Não & Sim & Não & 450 & 1970 & Sim & Não & 4,0 & Sim & Sim & Não & Não & & & $\mathrm{Sim}$ & & & & \\
\hline 194 & jan-08 & São Paulo & Não & Não & Não & Não & Não & sim & Não & 450 & 1970 & Sim & Não & 4,0 & Sim & $\mathrm{Sim}$ & Não & Não & & & sim & & & & \\
\hline 195 & fev-08 & São Paulo & Não & Não & Não & Não & Não & sim & Não & 450 & 1970 & Sim & Não & 4,0 & Não & Não & Não & Não & & & Sim & & & & \\
\hline 196 & mar-08 & São Pau & Não & Não & Não & Não & Não & Sim & $\mathrm{N}$ & 45 & 197 & Sim & $\mathrm{N}$ & 4,0 & Não & Nã & $\mathrm{N}$ & Nã & & & Sim & & & & \\
\hline 197 & abr-08 & São Paulo & Não & Não & Não & Não & Não & Sim & Não & 450 & 19 & Sim & Não & 4,0 & Não & Não & Não & Não & & & Sim & & & & \\
\hline 198 & mai-08 & São Paulo & Não & Não & Não & Não & Não & Sim & Não & 450 & 1970 & Sim & Não & 4,0 & Não & Não & Não & Não & & & Sim & & & & \\
\hline 199 & jun-08 & São Paulo & Não & Não & Não & Não & Não & Sim & Não & 450 & 1970 & Sim & Não & 4,0 & Não & Não & Não & Não & & & Sim & & & & \\
\hline 200 & jul-08 & $\begin{array}{l}\begin{array}{l}\text { São Paulo } \\
\text { São Paulo }\end{array}\end{array}$ & Não & Não & Não & Não & Não & sim & Não & $\begin{array}{l}450 \\
450\end{array}$ & 1970 & Sim & $\begin{array}{l}\text { Não } \\
\text { Não }\end{array}$ & $\begin{array}{l}4,0 \\
40\end{array}$ & Não & $\begin{array}{l}\text { Não } \\
\text { Não }\end{array}$ & Não & $\begin{array}{l}\text { Não } \\
\text { Não }\end{array}$ & & & Sim & & & & \\
\hline 201 & $\begin{array}{r}\text { ago-08 } \\
\text { set-08 }\end{array}$ & $\begin{array}{l}\text { Säo Paulo } \\
\text { São Palo }\end{array}$ & $\begin{array}{l}\text { Não } \\
\text { Não }\end{array}$ & $\begin{array}{l}\text { Não } \\
\text { Nã }\end{array}$ & $\begin{array}{l}\text { Não } \\
\text { Não }\end{array}$ & $\begin{array}{l}\text { Não } \\
\text { Năo }\end{array}$ & $\begin{array}{l}\text { Não } \\
\text { Não }\end{array}$ & Sim & $\begin{array}{l}\text { Não } \\
\text { Não }\end{array}$ & 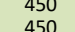 & $\begin{array}{l}1970 \\
1970\end{array}$ & $\begin{array}{l}\text { Sim } \\
\text { Sim }\end{array}$ & $\begin{array}{l}\text { Não } \\
\text { Não }\end{array}$ & $\begin{array}{l}4,0 \\
40\end{array}$ & $\begin{array}{l}\text { Não } \\
\text { Não }\end{array}$ & $\begin{array}{l}\text { Não } \\
\text { Não }\end{array}$ & $\begin{array}{l}\text { Não } \\
\text { Năno }\end{array}$ & $\begin{array}{l}\text { Não } \\
\text { Năno }\end{array}$ & & & Sim & & & & \\
\hline 203 & $\begin{array}{c}\text { set-08 } \\
\text { out-08 }\end{array}$ & São Paulo & $\begin{array}{l}\text { Nao } \\
\text { Nãoo }\end{array}$ & $\begin{array}{l}\text { Năo } \\
\text { Não }\end{array}$ & $\begin{array}{l}\text { Nào } \\
\text { Não }\end{array}$ & $\begin{array}{l}\text { Nao } \\
\text { Não }\end{array}$ & $\begin{array}{l}\text { Não } \\
\text { Não }\end{array}$ & $\begin{array}{l}\text { Sim } \\
\text { Sim }\end{array}$ & $\begin{array}{l}\text { Nào } \\
\text { Não }\end{array}$ & $\begin{array}{l}450 \\
450\end{array}$ & $\begin{array}{l}1970 \\
1970\end{array}$ & $\begin{array}{l}\text { Sim } \\
\text { Sim }\end{array}$ & $\begin{array}{l}\text { Năo } \\
\text { Não }\end{array}$ & $\begin{array}{l}4,0 \\
4,0\end{array}$ & $\begin{array}{l}\text { Não } \\
\text { Não }\end{array}$ & $\begin{array}{l}\text { Năo } \\
\text { Não }\end{array}$ & $\begin{array}{l}\text { Não } \\
\text { Não }\end{array}$ & $\begin{array}{l}\text { Năo } \\
\text { Não }\end{array}$ & & & Sim & & & & \\
\hline 204 & nov-08 & São Paulo & Não & Não & Não & Não & Não & Não & Sim & 450 & 1970 & Sim & Não & $\begin{array}{l}4,0 \\
4,0\end{array}$ & Não & Não & Não & Não & & & $\mathrm{Sim}$ & & & & \\
\hline
\end{tabular}




\begin{tabular}{|c|c|c|c|c|c|c|c|c|c|c|c|c|c|c|c|c|c|c|c|c|c|c|c|c|c|}
\hline \multirow[b]{2}{*}{ ID } & \multirow[b]{2}{*}{\begin{tabular}{|c|} 
Data \\
Registro
\end{tabular}} & \multirow{2}{*}{\begin{tabular}{|l} 
IDENTIFICAÇĀO \\
cidade
\end{tabular}} & & & ERENC & CONAN & $\mathrm{A} / \mathrm{CE}$ & & & DADOS & O POSTO & Con & exto geoló & & FASE & APOR & FASE & ETIDA & LN/ & APL & Dis & solv & & & \\
\hline & & & AvP & IC & ID & Artx & $\mathrm{PI}$ & REM & ME & $\begin{array}{c}\text { Área } \\
\text { m2 }\end{array}$ & $\begin{array}{l}\text { Data } \\
\text { instala }\end{array}$ & Sed. & $\begin{array}{l}\text { Rocha } \\
\text { alterada }\end{array}$ & $\begin{array}{l}\text { ZN Sat } \\
\text { (m) }\end{array}$ & $\begin{array}{c}\text { Detectado } \\
?\end{array}$ & $\begin{array}{c}\text { Delimitado } \\
?\end{array}$ & $\begin{array}{c}\text { Detectado } \\
?\end{array}$ & $\begin{array}{c}\text { Delimitado } \\
?\end{array}$ & $\mid \begin{array}{c}\text { Detectado } \\
?\end{array} ?$ & Delimit & $\begin{array}{c}\text { Detectado } \\
\text { ? }\end{array}$ & $\begin{array}{c}\text { Delimitada } \\
?\end{array}$ & $\mid \begin{array}{c}\text { Remediação } \\
?\end{array}$ & $\begin{array}{c}\text { Remediação } \\
\text { Z Nsatu? }\end{array} \mid$ & $\begin{array}{l}\text { Remediaçã } \\
\text { Z Sat? }\end{array}$ \\
\hline 205 & & São Paulo & Não & Não & Não & Não & Não & Não & Sim & 450 & 1970 & $\operatorname{sim}$ & Não & 4,0 & Não & Não & Não & Não & & & Sim & & & & \\
\hline 206 & \begin{tabular}{|l|} 
mar-09 \\
\end{tabular} & São Paulo & Não & Não & Não & Não & Não & Não & Sim & 450 & 1970 & Sim & Não & 4,0 & Não & Não & Não & Não & & & Sim & & & & \\
\hline 207 & mar-10 & São Paulo & Não & Não & Não & Não & Não & Não & sim & 450 & 1970 & Sim & Não & 4,0 & Não & Não & Não & Não & & & sim & & & & \\
\hline 208 & set-10 & São Paulo & Não & Não & Não & Não & Não & Não & Sim & 450 & 1970 & Sim & Não & 4,0 & Não & Não & Não & Não & & & Sim & & & & \\
\hline 209 & mai-11 & São Paulo & Não & Não & Não & Não & Não & Não & sim & 450 & 1970 & Sim & Não & 4,0 & Não & Não & Não & Não & & & Sim & & & & \\
\hline $\begin{array}{l}210 \\
211\end{array}$ & $\begin{array}{r}\text { jun-13 } \\
\text { set-13 }\end{array}$ & $\begin{array}{l}\text { São Paulo } \\
\text { São Paulo }\end{array}$ & $\begin{array}{l}\text { Não } \\
\text { Nẵo }\end{array}$ & $\begin{array}{l}\text { Não } \\
\text { Năo }\end{array}$ & $\begin{array}{l}\text { Sim } \\
\text { Não }\end{array}$ & $\begin{array}{l}\text { Sim } \\
\text { Não }\end{array}$ & $\begin{array}{l}\text { Não } \\
\text { Não }\end{array}$ & Não & $\begin{array}{l}\text { Não } \\
\text { Sim }\end{array}$ & $\begin{array}{l}450 \\
450\end{array}$ & $\begin{array}{l}1970 \\
1970\end{array}$ & Sim & Não & 2,2 & Sim & Não & $\begin{array}{l}\text { Não } \\
\text { Não }\end{array}$ & $\begin{array}{l}\text { Não } \\
\text { Não }\end{array}$ & Não & Não & Sim & & & & \\
\hline $\begin{array}{l}211 \\
212\end{array}$ & $\begin{array}{r}\text { set-13 } \\
\text { mar-03 }\end{array}$ & $\begin{array}{l}\text { Săo Paulo } \\
\text { São Sebastião }\end{array}$ & $\begin{array}{l}\text { Não } \\
\text { Sim }\end{array}$ & $\begin{array}{l}\text { Năo } \\
\text { Sim }\end{array}$ & $\begin{array}{l}\text { Não } \\
\text { Nẫo }\end{array}$ & $\begin{array}{l}\text { Não } \\
\text { Não }\end{array}$ & $\begin{array}{l}\text { Não } \\
\text { Não }\end{array}$ & $\begin{array}{l}\text { Sim } \\
\text { Não }\end{array}$ & $\begin{array}{l}\text { Sim } \\
\text { Não }\end{array}$ & $\begin{array}{l}450 \\
1064\end{array}$ & $\begin{array}{l}1970 \\
1989\end{array}$ & $\begin{array}{l}\text { Sim } \\
\text { Sim }\end{array}$ & $\begin{array}{l}\text { Não } \\
\text { Não }\end{array}$ & $\begin{array}{l}2,2 \\
1,0\end{array}$ & $\begin{array}{l}\text { Sim } \\
\text { Sim }\end{array}$ & $\begin{array}{l}\text { Não } \\
\text { Não }\end{array}$ & $\begin{array}{l}\text { Não } \\
\text { Sim }\end{array}$ & $\begin{array}{l}\text { Não } \\
\text { Não }\end{array}$ & $\begin{array}{l}\text { Não } \\
\text { Não }\end{array}$ & $\begin{array}{l}\text { Não } \\
\text { Não }\end{array}$ & Sim & & & & \\
\hline 213 & 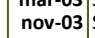 & $\begin{array}{l}\text { Saðo Sebastião } \\
\text { São }\end{array}$ & Não & Não & $\begin{array}{l}\text { Nao } \\
\text { Sim }\end{array}$ & $\begin{array}{l}\text { Nao } \\
\text { Sim }\end{array}$ & $\begin{array}{l}\text { Nao } \\
\text { Não }\end{array}$ & $\begin{array}{l}\text { Nao } \\
\text { Não }\end{array}$ & $\begin{array}{l}\text { Nao } \\
\text { Não }\end{array}$ & 1004 & 1989 & $\operatorname{sim}$ & $\begin{array}{l}\text { Nao } \\
\text { Não }\end{array}$ & $\begin{array}{l}1,0 \\
1,0\end{array}$ & Sim & $\begin{array}{l}\text { Nao } \\
\text { Sim }\end{array}$ & Sim & $\begin{array}{l}\text { Nao } \\
\text { Sim }\end{array}$ & $\begin{array}{l}\text { Noo } \\
\text { Não }\end{array}$ & $\begin{array}{l}\text { Nao } \\
\text { Não }\end{array}$ & Sim & Sim & Não & & Não \\
\hline 214 & mar-04 & São Sebastião & Não & Não & Não & Não & Sim & Sim & Não & & & Sim & Não & $\begin{array}{l}1,0 \\
1,0\end{array}$ & & & & & & & IIm & (Iin & Sim & Sim & Sim \\
\hline 215 & & São Sebastião & Não & Não & Não & Não & Não & Sim & Não & & & Sim & Não & 1,0 & Sim & Sim & Sim & Sim & Não & Não & Sim & Sim & Sim & Sim & Sim \\
\hline 216 & dez-06 & São Sebastião & Não & Não & Não & & Não & Não & Sim & & & Sim & Não & 1,0 & Sim & Sim & Sim & sim & Não & Não & sim & sim & Näo & Näo & Não \\
\hline 217 & jun-07| & São Sebastião & Não & Não & Não & Não & Não & Não & Sim & & & sim & Não & 1,0 & Sim & Sim & Sim & Sim & Não & Não & Sim & sim & Não & Não & Năอ \\
\hline 218 & dez-07 & São Sebastião & Não & Não & Não & Não & Não & Não & sim & & & Sim & Não & 1,0 & Sim & sim & Sim & Sim & Não & Não & sim & Sim & Não & Não & Não \\
\hline 219 & jun-08 & São Sebastião & Não & Não & Não & Não & Não & Não & sim & & & sim & Não & 1,0 & sim & sim & Sim & sim & Não & Não & sim & sim & Não & Não & Não \\
\hline 220 & abr-04 & Atibaia & Sim & Sim & Não & Não & Não & Não & Não & 9000 & 2000 & Não & Sim & 6,5 & Sim & Não & Não & Não & Não & Não & Sim & & & & \\
\hline 221 & jun-04 & Atibaia & Não & Não & Não & Não & Não & Sim & Não & 9000 & 2000 & Não & Sim & 6,5 & Não & Não & Sim & Não & Não & Não & Não & & Sim & Sim & \\
\hline 222 & nov-07: & Atibaia & Não & Não & Sim & Sim & Não & Não & Sim & 9000 & 2000 & Não & & 6,5 & Sim & Não & Sim & Não & Não & Não & Sim & & & & \\
\hline 223 & $\begin{array}{l}\text { dez-07 } \\
\text { dez-00 }\end{array}$ & São Paulo & Sim & Sim & Não & Não & Não & sim & Sim & 770 & 1993 & Sim & Não & 1,3 & Sim & Não & $\operatorname{Sim}$ & Não & & & & & Sim & $\operatorname{sim}$ & \\
\hline 224 & $\begin{array}{c}\text { dez-00 } \\
\text { mar-01 }\end{array}$ & $\begin{array}{l}\text { Sorocaba } \\
\text { Sorcaba }\end{array}$ & $\begin{array}{l}\text { Não } \\
\text { Nẵo }\end{array}$ & $\mathrm{Sim}_{\mathrm{Sim}}$ & $\begin{array}{l}\text { Não } \\
\text { Não }\end{array}$ & $\begin{array}{l}\text { Não } \\
\text { Não }\end{array}$ & $\begin{array}{l}\text { Não } \\
\text { Nă }\end{array}$ & $\begin{array}{l}\text { Não } \\
\text { Não }\end{array}$ & $\begin{array}{l}\text { Sim }_{\text {Não }} \\
\text { ano }\end{array}$ & $\begin{array}{l}700 \\
700\end{array}$ & $\begin{array}{l}1998 \\
1998\end{array}$ & $\begin{array}{l}\text { Sim } \\
\text { Sim }\end{array}$ & $\begin{array}{l}\text { Não } \\
\text { Não }\end{array}$ & $\begin{array}{l}1,3 \\
1,3\end{array}$ & & & $\begin{array}{l}\text { Não } \\
\text { Sim }\end{array}$ & $\begin{array}{l}\text { Não } \\
\text { Não }\end{array}$ & Sim & Não & Sim & & Não & Não & \\
\hline $\begin{array}{l}225 \\
226\end{array}$ & $\begin{array}{c}\left.\begin{array}{c}m a r-01 \\
\text { nov-01 }\end{array}\right] \\
\text {. }\end{array}$ & $\begin{array}{l}\text { Sorocaba } \\
\text { Sorocaba }\end{array}$ & $\begin{array}{l}\text { Não } \\
\text { Não }\end{array}$ & $\begin{array}{l}\text { Sim } \\
\text { Não }\end{array}$ & $\begin{array}{l}\text { Não } \\
\text { Não }\end{array}$ & $\begin{array}{l}\text { Não } \\
\text { Não }\end{array}$ & $\begin{array}{l}\text { Não } \\
\text { Não }\end{array}$ & $\begin{array}{l}\text { Não } \\
\text { Sim }\end{array}$ & $\begin{array}{l}\text { Não } \\
\text { Não }\end{array}$ & $\begin{array}{l}700 \\
700\end{array}$ & $\begin{array}{l}1998 \\
1998\end{array}$ & $\begin{array}{l}\text { Sim } \\
\text { Sim }\end{array}$ & $\begin{array}{l}\text { Não } \\
\text { Não }\end{array}$ & $\begin{array}{l}1,3 \\
1,3\end{array}$ & $\underset{S i m}{S i m}$ & $\begin{array}{l}\text { Não } \\
\text { Não }\end{array}$ & $\begin{array}{l}\text { Sim } \\
\text { Não }\end{array}$ & $\begin{array}{l}\text { Não } \\
\text { Não }\end{array}$ & $\begin{array}{l}\text { Sim } \\
\text { Sim }\end{array}$ & $\begin{array}{l}\text { Não } \\
\text { Não }\end{array}$ & $\begin{array}{l}\text { Sim } \\
\text { Sim }\end{array}$ & & $\begin{array}{l}\text { Não } \\
\text { Sim }\end{array}$ & $\begin{array}{l}\text { Não } \\
\text { Não }\end{array}$ & Sim \\
\hline 227 & abr-02 & Sorocaba & Não & $\begin{array}{l}\text { Nao } \\
\text { Não }\end{array}$ & $\begin{array}{l}\text { Nao } \\
\text { Não }\end{array}$ & $\begin{array}{l}\text { Nao } \\
\text { Sim }\end{array}$ & $\begin{array}{l}\text { Noo } \\
\text { Não }\end{array}$ & $\begin{array}{l}\text { Simm } \\
\text { Não }\end{array}$ & Não & 700 & $\begin{array}{l}1998 \\
1998\end{array}$ & $\begin{array}{l}\operatorname{sim} \\
\text { Sim }\end{array}$ & $\begin{array}{l}\text { Nao } \\
\text { Não }\end{array}$ & $\begin{array}{l}1,3 \\
1,3\end{array}$ & Sim & Não & Não & Não & Sim & Sim & sim & & Não & $\begin{array}{l}\text { Nao } \\
\text { Não }\end{array}$ & Sim \\
\hline 228 & jul-02 & Sorocaba & Não & Não & Não & Não & $\begin{array}{l}\text { Nao } \\
\text { Não }\end{array}$ & $\begin{array}{l}\text { Nao } \\
\text { Sim }\end{array}$ & Nâo & 700 & $\begin{array}{l}1998 \\
1998\end{array}$ & sim & Não & $\begin{array}{l}1,3 \\
1,3\end{array}$ & $\mathrm{Sim}$ & $\begin{array}{l}\text { Nao } \\
\text { Não }\end{array}$ & $\begin{array}{l}\text { Nao } \\
\text { Não }\end{array}$ & $\begin{array}{l}\text { Nao } \\
\text { Não }\end{array}$ & Sim & $\mathrm{Sim}$ & sim & & $\begin{array}{l}\text { Nao } \\
\text { Sim }\end{array}$ & $\begin{array}{l}\text { Nao } \\
\text { Sim }\end{array}$ & Sim \\
\hline 229 & $\begin{array}{l}\text { ago-02 } \\
\text { ano }\end{array}$ & Sorocaba & Não & Não & Não & Não & Não & Sim & Não & 700 & 1998 & Sim & Não & 1,3 & Sim & Não & Não & Não & Sim & sim & Sim & & Sim & Sim & $\mathrm{Sim}$ \\
\hline 230 & $\begin{array}{ll}\text { set }-02 & \end{array}$ & Sorocaba & Não & Não & Não & Não & Não & Sim & Não & 700 & 1998 & Sim & Não & 1,3 & Sim & Não & Não & Não & Sim & Sim & sim & & Sim & Sim & Sim \\
\hline 231 & \begin{tabular}{l|l} 
out-02 \\
\end{tabular} & Sorocaba & Não & Não & Não & Não & Não & Sim & Não & 700 & 1998 & Sim & Não & 1,3 & Sim & Não & Não & Não & Sim & sim & Sim & & Sim & Sim & sim \\
\hline 232 & nov-02 & Sorocaba & Não & Não & Não & Não & Não & Sim & Não & 700 & 1998 & sim & Não & 1,3 & sim & Não & Não & Não & Sim & Sim & sim & & Sim & Sim & Sim \\
\hline 233 & dez-02 & Sorocaba & Não & Não & Não & Não & Não & Sim & Não & 700 & 1998 & Sim & Não & 1,3 & Sim & Não & Não & Não & Não & Não & Sim & & Sim & Sim & Sim \\
\hline 234 & jan-03 & Sorocaba & Não & Não & Não & Não & Não & Sim & Não & 700 & 1998 & Sim & Não & 1,3 & Sim & Não & Não & Não & Sim & Sim & Sim & & Sim & Sim & Sim \\
\hline 235 & fev-03 & Sorocaba & Não & Não & Não & Não & Não & sim & Não & 700 & 1998 & sim & Não & 1,3 & Sim & Não & Não & Não & Sim & Sim & Sim & & Sim & Sim & Sim \\
\hline 236 & mar-03 & Sorocaba & Não & $\begin{array}{l}\text { Não } \\
\text { Não }\end{array}$ & Não & $\begin{array}{l}\text { Não } \\
\text { N20̃ }\end{array}$ & Não & Sim & Não & $\begin{array}{l}700 \\
700\end{array}$ & $\begin{array}{l}1998 \\
1998\end{array}$ & Sim & Não & $\begin{array}{l}1,3 \\
13\end{array}$ & Sim & Não & Sim & $\begin{array}{l}\text { Não } \\
\text { Não }\end{array}$ & Sim & Sim & Sim & & Sim & Sim & Sim \\
\hline $\begin{array}{l}237 \\
238\end{array}$ & $\begin{array}{c}\text { abr-03 } \\
\text { mai-03 }\end{array}$ & $\begin{array}{l}\text { Sorocaba } \\
\text { Sorocaba }\end{array}$ & $\begin{array}{l}\text { Não } \\
\text { Não }\end{array}$ & $\begin{array}{l}\text { Não } \\
\text { Năo }\end{array}$ & $\begin{array}{l}\text { Não } \\
\text { Nẫo }\end{array}$ & $\begin{array}{l}\text { Não } \\
\text { Não }\end{array}$ & $\begin{array}{l}\text { Não } \\
\text { Não }\end{array}$ & $\begin{array}{l}\text { Sim } \\
\text { Sim }\end{array}$ & $\begin{array}{l}\text { Não } \\
\text { Não }\end{array}$ & $\begin{array}{l}700 \\
700\end{array}$ & $\begin{array}{l}1998 \\
1998\end{array}$ & $\begin{array}{l}\text { Sim } \\
\text { Sim }\end{array}$ & $\begin{array}{l}\text { Não } \\
\text { Năo }\end{array}$ & $\begin{array}{l}1,3 \\
1,3\end{array}$ & $\begin{array}{l}\text { Sim } \\
\text { Sim }\end{array}$ & $\begin{array}{l}\text { Não } \\
\text { Năo }\end{array}$ & $\begin{array}{l}\text { Sim } \\
\text { Sim }\end{array}$ & $\begin{array}{l}\text { Não } \\
\text { Năo }\end{array}$ & $\begin{array}{l}\text { Sim } \\
\text { Sim }\end{array}$ & $\begin{array}{l}\text { Sim } \\
\text { Sim }\end{array}$ & $\begin{array}{l}\text { Sim } \\
\text { Sim }\end{array}$ & & $\begin{array}{l}\text { Sim } \\
\text { Sim }\end{array}$ & $\begin{array}{l}\text { Sim } \\
\text { Sim }\end{array}$ & $\begin{array}{l}\text { Sim } \\
\text { Sim }\end{array}$ \\
\hline 239 & $\begin{array}{c}m_{j}^{m a 1-03}-03 \\
\text { jun }\end{array}$ & $\begin{array}{l}\text { Sorocababa } \\
\text { Sorocababa }\end{array}$ & $\begin{array}{l}\text { Não } \\
\text { Nâo }\end{array}$ & $\begin{array}{l}\text { Năo } \\
\text { Não }\end{array}$ & $\begin{array}{l}\text { Năo } \\
\text { Não }\end{array}$ & $\begin{array}{l}\text { Năo } \\
\text { Não }\end{array}$ & $\begin{array}{l}\text { Não } \\
\text { Não }\end{array}$ & $\begin{array}{l}\text { Sim } \\
\text { Sim }\end{array}$ & $\begin{array}{l}\text { Nâo } \\
\text { Nâo }\end{array}$ & 700 & $\begin{array}{l}1998 \\
1998\end{array}$ & $\begin{array}{l}\text { Sim } \\
\text { Sim }\end{array}$ & $\begin{array}{l}\text { Não } \\
\text { Não }\end{array}$ & $\begin{array}{l}1,3 \\
1,3\end{array}$ & $\begin{array}{l}\text { Sim } \\
\text { Sim }\end{array}$ & $\begin{array}{l}\text { Não } \\
\text { Não }\end{array}$ & $\begin{array}{l}\text { Sim } \\
\text { Sim }\end{array}$ & $\begin{array}{l}\text { Não } \\
\text { Não }\end{array}$ & $\begin{array}{l}\text { Sim } \\
\text { Sim }\end{array}$ & $\begin{array}{l}\text { Sim } \\
\text { Sim }\end{array}$ & $\begin{array}{l}\text { Sim } \\
\text { Sim }\end{array}$ & & $\begin{array}{l}\text { Sim } \\
\text { Sim }\end{array}$ & Sim & $\begin{array}{l}\text { Sim } \\
\text { Sim }\end{array}$ \\
\hline 240 & jul-03 & Sorocaba & Não & Não & $\begin{array}{l}\text { Nao } \\
\text { Não }\end{array}$ & Não & Não & Sim & Não & 700 & 1998 & sim & Não & 1,3 & sim & Não & Não & Não & $\mathrm{Sim}$ & $\mathrm{Sim}$ & Não & & $\mathrm{Sim}$ & $\mathrm{Sim}$ & $\mathrm{Sim}$ \\
\hline 241 & ago-03 & Sorocaba & Não & Não & Não & Não & Não & Sim & Não & 700 & 1998 & Sim & Não & 1,3 & sim & Não & $\begin{array}{l}\text { Nao } \\
\text { Não }\end{array}$ & $\begin{array}{l}\text { Nao } \\
\text { Não }\end{array}$ & $\mathrm{Sim}$ & $\mathrm{Sim}$ & $\begin{array}{l}\text { Nao } \\
\text { Não }\end{array}$ & & Sim & Sim & Sim \\
\hline 242 & \begin{tabular}{l|l} 
& set -03 \\
\end{tabular} & Sorocaba & Não & Não & Não & Não & Não & Sim & Não & 700 & 1998 & Sim & Não & 1,3 & Sim & Não & Não & Não & Sim & Sim & Não & & Sim & Sim & Sim \\
\hline 243 & \begin{tabular}{c|c} 
out -03 &
\end{tabular} & Sorocaba & Não & Não & Não & Não & Não & Sim & Não & 700 & 1998 & Sim & Não & 1,3 & Sim & Não & Não & Não & Sim & sim & Não & & Sim & Sim & Sim \\
\hline 244 & \begin{tabular}{l|l} 
nov- 03 \\
\end{tabular} & Sorocaba & Não & Não & Não & Não & Não & Sim & Não & 700 & 1998 & Sim & Não & 1,3 & sim & Não & Não & Não & Sim & Sim & Não & & Sim & Sim & Sim \\
\hline 245 & dez-03 & Sorocaba & Não & Não & Não & Não & Não & Sim & Não & 700 & 1998 & Sim & Não & 1,3 & Sim & Não & Sim & Não & Sim & Sim & Não & & Sim & Sim & Sim \\
\hline 246 & jan-04 & Soroca & Não & Não & Não & Não & Não & Sim & Não & 700 & 1998 & Sim & Não & 1,3 & Sim & Não & Sim & Não & Sim & Sim & Não & & Sim & Sim & Sim \\
\hline 247 & fev-04 & Soroc & Não & Não & Não & Não & Não & Sim & Não & 700 & 1998 & Sim & Não & 1,3 & Sim & Não & Não & Não & Sim & Sim & Sim & Sim & Sim & Sim & Sim \\
\hline 248 & mar-04 & Sorocaba & Não & Não & Não & Não & Não & sim & Não & 700 & 1998 & Sim & Não & 1,3 & Sim & Sim & Não & Não & Sim & Sim & Não & & Sim & Sim & Sim \\
\hline $\begin{array}{l}249 \\
250\end{array}$ & $\begin{array}{c}\text { abr-04 } \\
\text { mai-04 }\end{array}$ & $\begin{array}{l}\text { Sorocaba } \\
\text { Sorocaba }\end{array}$ & $\begin{array}{l}\text { Não } \\
\text { Nẫo }\end{array}$ & $\begin{array}{l}\text { Não } \\
\text { Não }\end{array}$ & $\begin{array}{l}\text { Não } \\
\text { Não }\end{array}$ & $\begin{array}{l}\text { Não } \\
\text { Não }\end{array}$ & $\begin{array}{l}\text { Não } \\
\text { Nă }\end{array}$ & $\begin{array}{l}\text { Sim } \\
\text { Sim }\end{array}$ & $\begin{array}{l}\text { Não } \\
\text { Não }\end{array}$ & $\begin{array}{l}700 \\
700\end{array}$ & $\begin{array}{l}1998 \\
1998\end{array}$ & $\begin{array}{l}\text { Sim } \\
\text { Sim }\end{array}$ & $\begin{array}{l}\text { Não } \\
\text { Nâo }\end{array}$ & $\begin{array}{l}1,3 \\
13\end{array}$ & Sim & Sim & Não & $\begin{array}{l}\text { Não } \\
\text { Não }\end{array}$ & Sim & Sim & $\begin{array}{l}\text { Não } \\
\text { Não }\end{array}$ & & Sim & Sim & Sim \\
\hline $\begin{array}{l}250 \\
251\end{array}$ & $\begin{array}{l}m \text { mal-04 } \\
\text { ago-04 }\end{array}$ & $\begin{array}{l}\text { Sorocaba } \\
\text { Sorocaba }\end{array}$ & $\begin{array}{l}\text { Não } \\
\text { Não }\end{array}$ & $\begin{array}{l}\text { Não } \\
\text { Não }\end{array}$ & $\begin{array}{l}\text { Não } \\
\text { Não }\end{array}$ & $\begin{array}{l}\text { Não } \\
\text { Não }\end{array}$ & $\begin{array}{l}\text { Não } \\
\text { Não }\end{array}$ & $\begin{array}{l}\text { Sim } \\
\text { Sim }\end{array}$ & $\begin{array}{l}\text { Não } \\
\text { Não }\end{array}$ & 700 & $\begin{array}{l}1998 \\
1998\end{array}$ & $\begin{array}{l}\text { Sim } \\
\text { Sim }\end{array}$ & $\begin{array}{l}\text { Não } \\
\text { Năo }\end{array}$ & $\begin{array}{l}1,3 \\
1,3\end{array}$ & $\begin{array}{l}\text { Sim } \\
\text { Sim }\end{array}$ & $\begin{array}{l}\text { Sim } \\
\text { Sim }\end{array}$ & $\begin{array}{l}\text { Não } \\
\text { Não }\end{array}$ & $\begin{array}{l}\text { Não } \\
\text { Não }\end{array}$ & $\begin{array}{l}\text { Não } \\
\text { Não }\end{array}$ & $\begin{array}{l}\text { Não } \\
\text { Não }\end{array}$ & $\begin{array}{l}\text { Não } \\
\text { Não }\end{array}$ & & Sim & Sim & $\begin{array}{l}\text { Sim } \\
\text { Sim }\end{array}$ \\
\hline 252 & set-04 & Sorocaba & $\begin{array}{l}\text { Não } \\
\text { Nâ }\end{array}$ & Não & $\begin{array}{l}\text { Nao } \\
\text { Não }\end{array}$ & $\begin{array}{l}\text { Nao } \\
\text { Não }\end{array}$ & $\begin{array}{l}\text { Nao } \\
\text { Não }\end{array}$ & Sim & Não & 700 & 1998 & Sim & $\begin{array}{l}\text { Nao } \\
\text { Não }\end{array}$ & 1,3 & $\mathrm{Sim}$ & Sim & $\begin{array}{l}\text { Nao } \\
\text { Não }\end{array}$ & Não & $\begin{array}{l}\text { Não } \\
\text { Não }\end{array}$ & Não & $\begin{array}{l}\text { Não } \\
\text { Nân }\end{array}$ & & Sim & $\mathrm{Sim}$ & Sim \\
\hline 253 & out-04 & Sorocaba & Não & Não & Não & Não & $\begin{array}{l}\text { Não } \\
\text { Nã }\end{array}$ & Sim & Não & 700 & 1998 & Sim & Não & 1,3 & Não & Não & Não & Não & Não & Não & Não & & Sim & $\mathrm{Sim}$ & Sim \\
\hline 254 & & Sorocaba & Não & Não & Não & Não & Não & Sim & & 70 & 1998 & Sim & Não & 1,3 & Não & Não & Não & Não & Não & $\mathrm{N}$ & Não & & Sim & sim & Sim \\
\hline 255 & dez-04 & Sorocaba & Não & Não & Sim & Sim & Não & Não & Sim & 700 & 1998 & Sim & Não & 1,3 & Não & Não & Não & Não & Não & $\mathrm{N}$ & Não & & Sim & & Jimi \\
\hline 256 & fev-03 & Cabrália Paulista & Sim & Sim & Não & Não & Não & Não & Não & 20000 & 1972 & Não & Sim & 5,0 & Não & Não & Não & Não & Não & Não & Não & & Não & Não & \\
\hline 257 & abr-03 & São Paulo & Sim & Sim & Não & Não & Não & Não & Não & 907 & 1973 & Sim & Não & 4,0 & Sim & Não & Sim & Não & Não & Não & Não & & Não & Não & Não \\
\hline 258 & abr-09 & São Pa & Não & Não & Sim & Sim & Não & Não & Não & 907 & 1973 & Sim & Não & 4,0 & Sim & Sim & Sim & Sim & Não & Não & Sim & Sim & Não & Não & Não \\
\hline 259 & out-09 & São Paulo & Não & Não & Não & Não & Não & Não & $\mathrm{Si}$ & 90 & 197 & Sin & Não & 4,0 & & & & & Não & Não & Sim & Sim & & & \\
\hline 260 & abr-10 & São Pat & Não & Não & Não & Não & Não & Não & Si & 907 & 1973 & Sim & Não & 4,0 & & & & & Nã & Não & Sim & Sim & & & \\
\hline 261 & out-10 & São Pa & Não & Não & Não & Não & Não & Não & Sim & 907 & 1973 & Sim & Não & 4,0 & & & & & Não & Não & Sim & Sim & & & \\
\hline 262 & abr-11 & São Paulo & Não & Não & Não & Não & Não & Não & Sim & 907 & 1973 & sim & Não & 4,0 & & & & & Não & Não & Sim & Sim & & & \\
\hline 263 & fev-03 & São Pau & Sim & Sim & Não & Não & Não & Não & Não & 252 & 1963 & Sim & Não & 3,0 & Sim & Não & Sim & Não & Não & Não & Não & & Não & Não & Não \\
\hline 264 & mar-10 & São Pa & Não & Não & Sim & Sim & Não & Não & Não & 252 & 1963 & Sim & Não & 3,0 & Sim & Sim & Sim & Sim & Não & Não & Sim & Sim & Não & Não & Não \\
\hline 265 & jun-12 & São Pau & Não & Não & Não & Não & Não & Não & $\mathrm{Si}$ & 252 & 1963 & Sim & Não & 3,0 & & & & & Não & Não & Sim & Sim & & & \\
\hline 266 & fev-13 & São Pa & Não & Não & Não & Não & Não & Não & si & 252 & 1963 & Sim & Não & 3,0 & & & & & Não & Não & Sim & Sim & & & \\
\hline 267 & set. & São Paulo & Não & Não & Não & Não & Não & Não & Sim & 252 & 1963 & Sim & Não & 3,0 & & & & & Não & & & & & & \\
\hline 268 & jul-14 & São Paulo & Não & Não & Não & Não & Não & Não & Sim & 252 & 1963 & Sim & Não & 3,0 & & & & & Não & Não & Sim & Sim & & & \\
\hline 269 & jul-13 & Sumaré & Não & Sim & Não & Não & Não & Sim & Não & 1250 & 1995 & Sim & Não & 6,3 & Sim & Não & & & Não & Não & Sim & & Sim & & Não \\
\hline 270 & ago-13 & Sumaré & Não & Não & Sim & Não & Não & Não & Não & 1250 & 1995 & Sim & Não & 6,3 & Não & Não & & & Não & Não & Sim & Sim & & & \\
\hline 271 & ago-14 & Sumaré & Não & Não & Não & Não & Não & Não & Sim & 1250 & 1995 & Sim & Não & 6,3 & Não & Não & & & Não & Não & Sim & Sim & & & \\
\hline 272 & out-14 & Sumaré & Não & Não & Não & Não & Não & Não & Sim & 1250 & 1995 & Sim & Não & 6,3 & Não & Não & & & Não & Não & Sim & Sim & & & \\
\hline
\end{tabular}




\begin{tabular}{|c|c|c|c|c|c|c|c|c|c|c|c|c|c|c|c|c|c|c|c|c|c|c|c|c|c|}
\hline \multirow[b]{2}{*}{ ID } & \multirow[b]{2}{*}{$\begin{array}{l}\text { Data } \\
\text { Registro }\end{array}$} & \multirow{2}{*}{$\begin{array}{l}\text { IDENTIFICAÇĀo } \\
\text { Cidade }\end{array}$} & \multicolumn{7}{|c|}{ GERENC CONAMA / CETESB } & DADOS & O POSTO & & exto geoló & & FASE & APOR & FASE & RETIDA & & APL & Dis & iolv & & & \\
\hline & & & AvP & IC & ID & Artx & PI & REM & ME & $\begin{array}{l}\text { Área } \\
\text { m2 }\end{array}$ & $\begin{array}{l}\text { Data } \\
\text { instala }\end{array}$ & Sed. & $\begin{array}{c}\text { Rocha } \\
\text { alterada }\end{array}$ & $\begin{array}{c}\text { ZN Sat } \\
(\mathrm{m})\end{array}$ & $\begin{array}{c}\text { Detectado } \\
?\end{array}$ & $\begin{array}{c}\text { Delimitado } \\
?\end{array}$ & $\begin{array}{c}\text { Detectado } \\
?\end{array}$ & $\begin{array}{c}\text { Delimitado } \\
?\end{array}$ & $\mid \begin{array}{c}\text { Detectado } \\
?\end{array}$ & Delimit & $\begin{array}{c}\text { Detectado } \\
?\end{array}$ & $\begin{array}{c}\text { Delimitada } \\
?\end{array}$ & $\begin{array}{c}\text { Remediação } \\
?\end{array}$ & $\begin{array}{c}\text { Remediação } \\
\text { Z Nsatu? }\end{array}$ & $\begin{array}{l}\text { Remediaçã } \\
\text { Z Sat? }\end{array}$ \\
\hline 273 & & Sumaré & Não & Não & Não & Não & Não & Não & Sim & 1250 & 1995 & Sim & Não & 6,3 & Não & Não & & & Não & Não & $\operatorname{sim}$ & Não & & & \\
\hline 274 & jan-16 & Sumaré & Não & Não & Não & Não & Não & Não & sim & 1250 & 1995 & Sim & Não & 6,3 & Não & Não & & & Não & Não & Sim & Sim & & & \\
\hline 275 & mar-16 & Sumaré & Não & Não & Não & Não & Não & Não & Sim & 1250 & 1995 & Sim & $\begin{array}{l}\text { Não } \\
\text { Nã }\end{array}$ & 6,3 & Não & Não & & & Năo & Não & Sim & Sim & & & \\
\hline 276 & dez-16 & Sumaré & Não & Não & Não & Não & Não & Não & Sim & 1250 & 1995 & Sim & Não & 6,3 & Não & Não & & & Não & Nâo & Sim & Sim & & & \\
\hline 277 & ago-09 & São Paulo & Não & Sim & Não & Não & Não & Sim & Não & 920 & 1977 & sim & Não & 1,2 & & & & & & & & & Sim & & \\
\hline 278 & jun-12 & São Paulo & Não & Não & Sim & Sim & Não & Não & Não & 920 & 1977 & Sim & Não & 1,2 & & & & & & & & & & & \\
\hline 279 & mar-13 & $\begin{array}{l}\text { São Paulo } \\
\text { São Paulo }\end{array}$ & Não & Não & Não & Não & Sim & Não & Não & 920 & 1977 & Sim & Não & 1,2 & Sim & Não & & & Sim & Sim & Sim & Não & & & \\
\hline $\begin{array}{l}280 \\
281\end{array}$ & $\mid \begin{array}{c}\text { marr-13 } \\
\text { out-13 }\end{array}$ & $\begin{array}{l}\text { São Paulo } \\
\text { São Palo }\end{array}$ & $\begin{array}{l}\text { Não } \\
\text { Não }\end{array}$ & $\begin{array}{l}\text { Não } \\
\text { Não }\end{array}$ & $\begin{array}{l}\text { Não } \\
\text { Não }\end{array}$ & $\begin{array}{l}\text { Não } \\
\text { Nãon }\end{array}$ & $\begin{array}{l}\text { Não } \\
\text { Não }\end{array}$ & $\begin{array}{l}\text { Sim } \\
\text { Não }\end{array}$ & $\begin{array}{l}\text { Não } \\
\text { Sim }\end{array}$ & $\begin{array}{l}920 \\
920\end{array}$ & $\begin{array}{l}1977 \\
1977\end{array}$ & $\begin{array}{l}\text { Sim } \\
\text { Sim }\end{array}$ & $\begin{array}{l}\text { Não } \\
\text { Não }\end{array}$ & $\begin{array}{l}1,2 \\
12\end{array}$ & Sim & Não & & & Sim & Sim & Sim & Sim & & & \\
\hline $\begin{array}{l}281 \\
282\end{array}$ & $\mid \begin{array}{l}\text { out-1s } \\
\text { mai-14 }\end{array}$ & $\begin{array}{l}\text { São Paulo } \\
\text { Sâlo }\end{array}$ & $\begin{array}{l}\text { Não } \\
\text { Não }\end{array}$ & $\begin{array}{l}\text { Não } \\
\text { Não }\end{array}$ & $\begin{array}{l}\text { Não } \\
\text { Não }\end{array}$ & $\begin{array}{l}\text { Não } \\
\text { Não }\end{array}$ & $\begin{array}{l}\text { Não } \\
\text { Não }\end{array}$ & $\begin{array}{l}\text { Não } \\
\text { Não }\end{array}$ & $\underset{\text { Sim }}{\text { Sim }}$ & $\begin{array}{l}920 \\
920\end{array}$ & $\begin{array}{l}1977 \\
1977\end{array}$ & $\begin{array}{l}\text { Sim } \\
\text { Sim }\end{array}$ & $\begin{array}{l}\text { Não } \\
\text { Não }\end{array}$ & $\begin{array}{l}1,2 \\
1,2\end{array}$ & & & & & & Não & $\begin{array}{l}\text { Sim } \\
\text { Sim }\end{array}$ & $\begin{array}{l}\text { Sim } \\
\text { Sim }\end{array}$ & & & \\
\hline $\begin{array}{l}282 \\
283\end{array}$ & $\mid$ & São Paulo & $\begin{array}{l}\text { Nao } \\
\text { Não }\end{array}$ & $\begin{array}{l}\text { Nao } \\
\text { Não }\end{array}$ & $\begin{array}{l}\text { Não } \\
\text { Não }\end{array}$ & $\begin{array}{l}\text { Năo } \\
\text { Não }\end{array}$ & $\begin{array}{l}\text { Não } \\
\text { Não }\end{array}$ & $\begin{array}{l}\text { Não } \\
\text { Não }\end{array}$ & Sim & 920 & 1977 & Sim & $\begin{array}{l}\text { Nao } \\
\text { Não }\end{array}$ & $\begin{array}{l}1,2 \\
1,2\end{array}$ & & & & & & & Sim & Sim & & & \\
\hline 284 & mai-15 & São Paulo & Não & Não & Não & Não & Não & Não & Sim & 920 & 1977 & Sim & Não & 1,2 & & & & & & & Sim & Não & & & \\
\hline 285 & nov-15 & São Paulo & Não & Não & Não & Não & Não & Não & Sim & 920 & 1977 & sim & Não & 1,2 & & & & & & & Sim & Sim & & & \\
\hline 286 & fev-16 & São Paulo & Não & & & & Não & Não & Sim & 920 & 1977 & Sim & Não & 1,2 & & & & & & & Sim & sim & & & \\
\hline 287 & jul-07 & Campinas & Não & Sim & Não & Não & Não & Sim & Não & 380 & 1975 & Sim & Não & 2,7 & Sim & Não & Sim & & Não & Não & Sim & & Sim & Sim & Não \\
\hline 288 & ago-11 & Campinas & Não & Não & Sim & Sim & Não & Não & Sim & 380 & 1975 & sim & Não & 2,7 & & & & & & & sim & Sim & & & \\
\hline 289 & out-11 & Campinas & Não & Não & Não & Não & Não & Não & sim & 380 & 1975 & Sim & Não & 2,7 & & & & & & & Sim & sim & & & \\
\hline 290 & abr-14 & Campinas & Não & Não & Não & Não & Não & Não & Sim & 380 & 1975 & Sim & Não & 2,7 & & & & & Não & Não & Sim & Sim & & & \\
\hline 291 & dez-14 & Campinas & Não & Não & Não & Não & Não & Não & Sim & 380 & 1975 & Sim & Não & 2,7 & & & Não & Não & Não & Não & Sim & Sim & & & \\
\hline 292 & 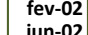 & $\begin{array}{l}\text { ã̃o Paulo } \\
\text { São Paulo }\end{array}$ & Não & Sim & Não & $\begin{array}{l}\text { Não } \\
\text { Sima }\end{array}$ & Não & Não & $\begin{array}{l}\text { Não } \\
\text { Não }\end{array}$ & $\begin{array}{l}300 \\
300\end{array}$ & $\begin{array}{l}1980 \\
1980\end{array}$ & Sim & Não & 8,2 & Sim & Não & Sim & Não & Não & Não & Sim & Não & & & \\
\hline 293 & $\begin{array}{l}\text { junn-02 } \\
\text { fev-05 }\end{array}$ & $\begin{array}{l}\text { Sấ Paulo } \\
\text { São Palo }\end{array}$ & $\begin{array}{l}\text { Não } \\
\text { Não }\end{array}$ & $\begin{array}{l}\text { Não } \\
\text { Não }\end{array}$ & Sim & $\begin{array}{l}\text { Sim } \\
\text { Não }\end{array}$ & $\begin{array}{l}\text { Não } \\
\text { Năo }\end{array}$ & $\begin{array}{l}\text { Não } \\
\text { Sim }\end{array}$ & $\begin{array}{l}\text { Não } \\
\text { Não }\end{array}$ & $\begin{array}{l}300 \\
300\end{array}$ & $\begin{array}{l}1980 \\
1980\end{array}$ & $\begin{array}{l}\text { Sim } \\
\text { Sim }\end{array}$ & $\begin{array}{l}\text { Não } \\
\text { Não }\end{array}$ & $\begin{array}{l}8,2 \\
8,2\end{array}$ & Sim & Não & Sim & Não & Sim & Não & Sim & Não & & & \\
\hline $\begin{array}{l}294 \\
295\end{array}$ & mar-07 & $\begin{array}{l}\text { Sao Paulo } \\
\text { São Paulo }\end{array}$ & $\begin{array}{l}\text { Não } \\
\text { Não }\end{array}$ & $\begin{array}{l}\text { Não } \\
\text { Não }\end{array}$ & $\begin{array}{l}\text { Não } \\
\text { Sim }\end{array}$ & $\begin{array}{l}\text { Não } \\
\text { Sim }\end{array}$ & $\begin{array}{l}\text { Não } \\
\text { Não }\end{array}$ & $\begin{array}{l}\text { Sim } \\
\text { Não }\end{array}$ & $\begin{array}{l}\text { Não } \\
\text { Nẫo }\end{array}$ & $\begin{array}{l}300 \\
300\end{array}$ & $\begin{array}{l}1980 \\
1980\end{array}$ & $\begin{array}{l}\text { Sim } \\
\text { Sim }\end{array}$ & $\begin{array}{l}\text { Não } \\
\text { Não }\end{array}$ & $\begin{array}{l}8,2 \\
8,2\end{array}$ & Sim & Não & Não & Não & Não & Não & $\mathrm{sim}$ & Não & & & \\
\hline 296 & $\begin{array}{l}\text { jul-07 } \\
\text { nat }\end{array}$ & $\begin{array}{l}\text { São Paulo } \\
\text { Sân }\end{array}$ & $\begin{array}{l}\text { Não } \\
\text { Nân }\end{array}$ & Não & Sim & Sim & $\begin{array}{l}\text { Nao } \\
\text { Não }\end{array}$ & $\begin{array}{l}\text { Não } \\
\text { Nâo }\end{array}$ & Não & 300 & 1980 & Sim & $\begin{array}{l}\text { Nao } \\
\text { Não }\end{array}$ & $\begin{array}{l}\text {, } 2 \\
8,2\end{array}$ & $\mathrm{Sim}$ & $\begin{array}{l}\text { Nao } \\
\text { Sim }\end{array}$ & $\begin{array}{l}\text { Nao } \\
\text { Não }\end{array}$ & $\begin{array}{l}\text { Nao } \\
\text { Não }\end{array}$ & Não & $\begin{array}{l}\text { Năo } \\
\text { Não }\end{array}$ & Sim & $\begin{array}{l}\text { Nao } \\
\text { Não }\end{array}$ & & & \\
\hline 297 & ago-08 & São Paulo & Não & $\begin{array}{l}\text { Nao } \\
\text { Não }\end{array}$ & Sim & Sim & Não & $\begin{array}{l}\text { Nao } \\
\text { Não }\end{array}$ & Não & 300 & 1980 & Sim & Não & 8,2 & Sim & $\mathrm{Sim}$ & Sim & Sim & Não & Não & Sim & Sim & & & \\
\hline 298 & jul-04 & São Paulo & Não & Não & Não & Não & $\begin{array}{l}\text { Nao } \\
\text { Sim }\end{array}$ & $\begin{array}{l}\text { Não } \\
\text { Não }\end{array}$ & Não & 300 & 1980 & SIm & Nao & $\begin{array}{l}8,2 \\
8,2\end{array}$ & & SIm & Sim & & & & & & & & \\
\hline 299 & dez-04 & São Paulo & Não & Não & Não & Não & Não & Sim & Não & 300 & 1980 & & & 8,2 & & & & & & & & & Sim & & Sim \\
\hline 300 & set-06 & São Paulo & Não & Não & Não & Não & Não & Sim & Não & 300 & 1980 & & & 8,2 & & & & & & & Sim & Sim & Sim & Sim & Sim \\
\hline 301 & nov-06 & São Paulo & Não & Não & Não & Não & Não & Sim & Não & 300 & 1980 & & & 8,2 & & & & & & & sim & sim & sim & Sim & Sim \\
\hline 302 & mar-07 & São Paulo & Não & Não & Não & Não & Não & Sim & Não & 300 & 1980 & & & 8,2 & & & & & & & Sim & Sim & Sim & Sim & Sim \\
\hline 303 & jun-07 & São Paulo & Não & Não & Não & Não & Não & Sim & Não & 300 & 1980 & & & 8,2 & & & & & & & Sim & Sim & Sim & Sim & Sim \\
\hline 304 & $\begin{array}{r}\text { set- } 07 \\
\text { rat }\end{array}$ & São Paulo & Não & Não & Não & Não & Não & Sim & Não & 300 & $\begin{array}{l}1980 \\
1080\end{array}$ & & & 8,2 & & & & & & & Sim & Sim & Sim & Sim & Sim \\
\hline $\begin{array}{l}305 \\
306\end{array}$ & $\begin{array}{l}\text { dez-07 } \\
\text { abr-08 }\end{array}$ & $\begin{array}{l}\text { ão Paulo } \\
\text { São Paulo }\end{array}$ & Não & $\begin{array}{l}\text { Não } \\
\text { Não }\end{array}$ & $\begin{array}{l}\text { Não } \\
\text { Não }\end{array}$ & $\begin{array}{l}\text { Não } \\
\text { Nãos }\end{array}$ & Não & $\begin{array}{l}\text { Sim } \\
\text { Sim }\end{array}$ & $\begin{array}{l}\text { Não } \\
\text { Não }\end{array}$ & $\begin{array}{l}300 \\
300\end{array}$ & $\begin{array}{l}1980 \\
1980\end{array}$ & & & $\begin{array}{l}8,2 \\
8,2\end{array}$ & & & & & & & Sim & Sim & Sim & Sim & sim \\
\hline $\begin{array}{l}306 \\
307\end{array}$ & $\begin{array}{r}\text { abb-08 } \\
\text { jul-08 }\end{array}$ & $\begin{array}{l}\text { São Paulo } \\
\text { São Paulo }\end{array}$ & $\begin{array}{l}\text { Não } \\
\text { Não }\end{array}$ & $\begin{array}{l}\text { Não } \\
\text { Não }\end{array}$ & $\begin{array}{l}\text { Não } \\
\text { Nẫo }\end{array}$ & $\begin{array}{l}\text { Não } \\
\text { Não }\end{array}$ & $\begin{array}{l}\text { Não } \\
\text { Não }\end{array}$ & $\begin{array}{l}\text { Sim } \\
\text { Sim }\end{array}$ & $\begin{array}{l}\text { Não } \\
\text { Não }\end{array}$ & $\begin{array}{l}300 \\
300\end{array}$ & $\begin{array}{l}1980 \\
1980\end{array}$ & & & $\begin{array}{l}8,2 \\
8,2\end{array}$ & & & & & & & Sim & Sim & Sim & Sim & Sim \\
\hline $\begin{array}{l}307 \\
308\end{array}$ & out-08 & $\begin{array}{l}\text { sao Paulo } \\
\text { São Paulo }\end{array}$ & $\begin{array}{l}\text { Não } \\
\text { Não }\end{array}$ & $\begin{array}{l}\text { Não } \\
\text { Não }\end{array}$ & $\begin{array}{l}\text { Não } \\
\text { Não }\end{array}$ & $\begin{array}{l}\text { Não } \\
\text { Não }\end{array}$ & $\begin{array}{l}\text { Não } \\
\text { Não }\end{array}$ & $\begin{array}{l}\text { Sim } \\
\text { Sim }\end{array}$ & $\begin{array}{l}\text { Não } \\
\text { Nẫo }\end{array}$ & $\begin{array}{l}300 \\
300\end{array}$ & $\begin{array}{l}1980 \\
1980\end{array}$ & & & $\begin{array}{l}8,2 \\
8,2\end{array}$ & & & & & & & $\begin{array}{l}\text { Sim } \\
\text { Sim }\end{array}$ & $\begin{array}{l}\text { Sim } \\
\text { Sim }\end{array}$ & $\begin{array}{l}\text { Sim } \\
\text { Sim }\end{array}$ & $\underset{\text { Sim }}{\text { Sim }}$ & Sim \\
\hline 309 & jan-09 & $\begin{array}{l}\text { São Paulo } \\
\text { Salo }\end{array}$ & $\begin{array}{l}\text { Não } \\
\text { Não }\end{array}$ & & $\begin{array}{l}\text { Não } \\
\text { Não }\end{array}$ & $\begin{array}{l}\text { Năo } \\
\text { Não }\end{array}$ & $\begin{array}{l}\text { Nao } \\
\text { Não }\end{array}$ & $\begin{array}{l}\text { Sim } \\
\text { Sim }\end{array}$ & $\begin{array}{l}\text { Nao } \\
\text { Não }\end{array}$ & 300 & 1980 & & & $\begin{array}{l}0,2 \\
8,2\end{array}$ & & & & & & & Sim & Sim & Sim & Sim & Sim \\
\hline 310 & abr-09 & São Paulo & $\begin{array}{l}\text { Nao } \\
\text { Não }\end{array}$ & $\begin{array}{l}\text { Nao } \\
\text { Não }\end{array}$ & $\begin{array}{l}\text { Nao } \\
\text { Não }\end{array}$ & $\begin{array}{l}\text { Nao } \\
\text { Não }\end{array}$ & $\begin{array}{l}\text { Nao } \\
\text { Não }\end{array}$ & Sim & Não & 300 & 1980 & & & $\begin{array}{l}8,2 \\
8,2\end{array}$ & & & & & & & sim & sim & sim & sim & $\mathrm{Sim}$ \\
\hline 311 & ago-09 & $\begin{array}{l}\text { São Paulo } \\
\text { Sal }\end{array}$ & Não & Não & Não & Não & Não & Sim & Não & 300 & 1980 & & & $\begin{array}{l}8,2 \\
8,2\end{array}$ & & & & & & & Sim & Sim & Sim & Sim & sim \\
\hline 312 & nov-09 & São Paulo & Não & Não & Não & Não & Não & Sim & Não & 300 & 1980 & & & 8,2 & & & & & & & sim & Sim & sim & sim & Sim \\
\hline 313 & fev-10 & São Paulo & Não & Não & Não & Não & Não & Sim & Não & 300 & 1980 & & & 8,2 & & & & & & & sim & sim & sim & Sim & Sim \\
\hline 314 & mai-10 & São Paulo & Não & Não & Não & Não & Não & Sim & Não & 300 & 1980 & & & 8,2 & & & & & & & Sim & Sim & Sim & $\mathrm{Sim}$ & Sim \\
\hline 315 & set-10 & São Paulo & Não & Não & Não & Não & Não & Sim & Não & 300 & 1980 & & & 8,2 & & & & & & & Sim & sim & sim & Sim & Sim \\
\hline 316 & dez-10 & São Paulo & Não & Não & Não & Não & Não & Sim & Não & 300 & 1980 & & & 8,2 & & & & & & & Sim & Sim & Sim & Sim & Sim \\
\hline 317 & mar-11 & São Paulo & Não & Não & Não & Não & Não & Sim & Não & 300 & $\begin{array}{l}1980 \\
1090\end{array}$ & & & 8,2 & & & & & & & Sim & Sim & Sim & Sim & Sim \\
\hline 318 & $\begin{array}{l}\text { jun-11 } \\
\text { set-11 }\end{array}$ & $\begin{array}{l}\text { ão Paulo } \\
\text { São Paulo }\end{array}$ & Não & $\begin{array}{l}\text { Não } \\
\text { Não }\end{array}$ & $\begin{array}{l}\text { Não } \\
\text { Não }\end{array}$ & $\begin{array}{l}\text { Não } \\
\text { Nãon }\end{array}$ & Não & Sim & $\begin{array}{l}\text { Não } \\
\text { Não }\end{array}$ & $\begin{array}{l}300 \\
300\end{array}$ & $\begin{array}{l}1980 \\
1980\end{array}$ & & & $\begin{array}{l}8,2 \\
8,2\end{array}$ & & & & & & & Sim & Sim & Sim & Sim & sim \\
\hline $\begin{array}{l}319 \\
320\end{array}$ & \begin{tabular}{|c} 
set-11 \\
jan-12
\end{tabular} & $\begin{array}{l}\text { Säo Paulo } \\
\text { São Paulo }\end{array}$ & $\begin{array}{l}\text { Não } \\
\text { Não }\end{array}$ & $\begin{array}{l}\text { Não } \\
\text { Não }\end{array}$ & $\begin{array}{l}\text { Não } \\
\text { Não }\end{array}$ & $\begin{array}{l}\text { Não } \\
\text { Não }\end{array}$ & $\begin{array}{l}\text { Não } \\
\text { Não }\end{array}$ & $\begin{array}{l}\text { Sim } \\
\text { sim }\end{array}$ & $\begin{array}{l}\text { Não } \\
\text { Não }\end{array}$ & $\begin{array}{l}300 \\
300\end{array}$ & $\begin{array}{l}1980 \\
1980\end{array}$ & & & $\begin{array}{l}8,2 \\
8,2\end{array}$ & & & & & & & Sim & Sim & Sim & Sim & Sim \\
\hline $\begin{array}{l}320 \\
321\end{array}$ & 势an-12 & $\begin{array}{l}\text { ao Paulo } \\
\text { São Paulo }\end{array}$ & $\begin{array}{l}\text { Não } \\
\text { Não }\end{array}$ & $\begin{array}{l}\text { Não } \\
\text { Não }\end{array}$ & $\begin{array}{l}\text { Não } \\
\text { Não }\end{array}$ & $\begin{array}{l}\text { Nâo } \\
\text { Não }\end{array}$ & $\begin{array}{l}\text { Não } \\
\text { Não }\end{array}$ & $\begin{array}{l}\text { Sim } \\
\text { Sim }\end{array}$ & $\begin{array}{l}\text { Nâo } \\
\text { Não }\end{array}$ & $\begin{array}{l}300 \\
300\end{array}$ & $\begin{array}{l}1980 \\
1980\end{array}$ & & & $\begin{array}{l}8,2 \\
82\end{array}$ & & & & & & & $\begin{array}{l}\text { Sim } \\
\text { Sim }\end{array}$ & $\begin{array}{l}\text { Sim } \\
\text { Sim }\end{array}$ & Sim & Sim & Sim \\
\hline $\begin{array}{l}321 \\
322\end{array}$ & jul-12 & $\begin{array}{l}\text { São Paulo } \\
\text { São }\end{array}$ & $\begin{array}{l}\text { Não } \\
\text { Não }\end{array}$ & $\begin{array}{l}\text { Não } \\
\text { Não }\end{array}$ & $\begin{array}{l}\text { Náo } \\
\text { Sim }\end{array}$ & $\begin{array}{l}\text { Năo } \\
\text { Não }\end{array}$ & $\begin{array}{l}\text { Nâo } \\
\text { Sim }\end{array}$ & $\begin{array}{l}\text { Sim } \\
\text { Sim }\end{array}$ & $\begin{array}{l}\text { Noo } \\
\text { Não }\end{array}$ & $\begin{array}{l}300 \\
300\end{array}$ & 1980 & & & $\begin{array}{l}0,2 \\
8,2\end{array}$ & & & Sim & Sim & & & sim & sim & sim & $\mathrm{Sim}$ & $\begin{array}{l}\text { Sim } \\
\text { Sim }\end{array}$ \\
\hline 323 & out-12 & São Paulo & $\begin{array}{l}\text { Nao } \\
\text { Não }\end{array}$ & $\begin{array}{l}\text { Nao } \\
\text { Não }\end{array}$ & Não & $\begin{array}{l}\text { Nao } \\
\text { Não }\end{array}$ & Não & sim & $\begin{array}{l}\text { Nao } \\
\text { Não }\end{array}$ & 300 & 1980 & & & $\begin{array}{l}0,2 \\
8,2\end{array}$ & & & Simi & Simi & & & Sim & sim & $\mathrm{Sim}$ & Sim & $\mathrm{Sim}$ \\
\hline $\begin{array}{l}324 \\
324\end{array}$ & mar-13 & $\begin{array}{l}\text { São Paulo } \\
\text { Sâlo }\end{array}$ & $\begin{array}{l}\text { Nao } \\
\text { Não }\end{array}$ & $\begin{array}{l}\text { Nao } \\
\text { Não }\end{array}$ & $\begin{array}{l}\text { Nao } \\
\text { Não }\end{array}$ & $\begin{array}{l}\text { Nao } \\
\text { Não }\end{array}$ & $\begin{array}{l}\text { Nao } \\
\text { Não }\end{array}$ & $\begin{array}{l}\text { SIm } \\
\text { Não }\end{array}$ & $\begin{array}{l}\mathrm{Ne} \\
\mathrm{Si}\end{array}$ & 300 & $\begin{array}{l}1980 \\
1980\end{array}$ & & & $\begin{array}{l}8,2 \\
10,0\end{array}$ & & & & & & & Sim & Sim & & & \\
\hline 325 & out-13 & São Paulo & Não & Não & Não & Não & Não & Não & Sim & 300 & 1980 & & & 10,0 & & & & & & & sim & sim & & & \\
\hline 326 & abr-14 & São Paulo & Não & Não & Não & Não & Não & Não & sim & 300 & 1980 & & & 10,0 & & & & & & & sim & sim & & & \\
\hline 327 & out-14 & São Paulo & Não & Não & Não & Não & Não & Não & sim & 300 & 1980 & & & 10,0 & & & & & & & sim & sim & & & \\
\hline 328 & out -04 & São Paulo & Sim & Sim & Não & Não & Não & Não & Não & 8000 & 1966 & Não & Sim & 6,5 & Sim & Não & Não & Não & Não & Não & Sim & Não & & & \\
\hline 329 & dez-04 & São Paulo & Não & Não & Sim & Não & Não & Não & Não & 8000 & 1966 & Não & Sim & 6,5 & Sim & Não & Sim & Não & Não & Não & Sim & Sim & & & \\
\hline 330 & jan-05 & São Paulo & Não & Não & Não & Sim & Não & Não & Sim & 8000 & 1966 & Não & Sim & 6,5 & Sim & Não & & N & & Não & Sim & Sim & & & \\
\hline 331 & $\begin{array}{r}\text { fev-05 } \\
m a r-06\end{array}$ & $\begin{array}{l}\text { Rio claro } \\
\text { Rio claro }\end{array}$ & Sim & Sim & $\begin{array}{l}\text { Não } \\
\text { Sim }\end{array}$ & $\begin{array}{l}\text { Não } \\
\text { Simim }\end{array}$ & $\begin{array}{l}\text { Não } \\
\text { Não }\end{array}$ & $\begin{array}{l}\text { Não } \\
\text { Não }\end{array}$ & $\begin{array}{l}\text { Não } \\
\text { Não }\end{array}$ & $\begin{array}{l}165 \\
165\end{array}$ & $\begin{array}{l}1999 \\
1999\end{array}$ & $\begin{array}{l}\text { Não } \\
\text { Nõ }\end{array}$ & Sim & $\begin{array}{l}11,0 \\
110\end{array}$ & & & Não & Não & Não & Não & & & & & \\
\hline 332 & $\begin{array}{c}m a r-06 \\
j ; a n-07\end{array}$ & $\begin{array}{l}\text { Rio claro } \\
\text { Rio claro }\end{array}$ & Não & $\begin{array}{l}\text { Não } \\
\text { Não }\end{array}$ & Sim & Sim & $\begin{array}{l}\text { Não } \\
\text { SSim }\end{array}$ & $\begin{array}{l}\text { Não } \\
\text { Sim }\end{array}$ & $\begin{array}{l}\text { Não } \\
\text { Naวิ }\end{array}$ & $\begin{array}{l}169 \\
169\end{array}$ & $\begin{array}{l}1999 \\
1999\end{array}$ & Não & Sim & $\begin{array}{l}11,0 \\
110\end{array}$ & $\begin{array}{l}\text { Não } \\
\text { Não }\end{array}$ & Não & $\begin{array}{l}\text { Não } \\
\text { Não }\end{array}$ & Não & Sim & Sim & Sim & Sim & & & \\
\hline $\begin{array}{l}335 \\
334\end{array}$ & fev-07 & Rio claro & $\begin{array}{l}\text { Não } \\
\text { Não }\end{array}$ & $\begin{array}{l}\text { Nao } \\
\text { Nãก }\end{array}$ & $\begin{array}{l}\text { Não } \\
\text { Não }\end{array}$ & $\begin{array}{l}\text { Nao } \\
\text { Nãก }\end{array}$ & Sก̃ & Sim & $\begin{array}{l}\text { Nao } \\
\text { Não }\end{array}$ & $\begin{array}{l}16900 \\
1690\end{array}$ & $\begin{array}{l}1999 \\
1999\end{array}$ & $\begin{array}{l}\text { Nao } \\
\text { Não }\end{array}$ & Sim & $\begin{array}{l}1,0 \\
110\end{array}$ & Nao & $\begin{array}{l}\text { Nao } \\
\text { Não }\end{array}$ & $\begin{array}{l}\text { Nao } \\
\text { Não }\end{array}$ & $\begin{array}{l}\text { Nao } \\
\text { Não }\end{array}$ & Sim & $\mathrm{Sim}$ & Sim & Sim & Sim & $\begin{array}{l}\text { Não } \\
\text { Não }\end{array}$ & Sim \\
\hline $\begin{array}{l}334 \\
335\end{array}$ & mar-07 & Rio claro & $\begin{array}{l}\text { Nao } \\
\text { Não }\end{array}$ & Não & Não & Não & Não & $\mathrm{Sim}$ & Não & 1690 & 1999 & Não & sim & 11,0 & $\mathrm{Sim}$ & Não & Não & Não & Sim & $\mathrm{Sim}$ & sim & sim & sim & Não & $\mathrm{Sim}$ \\
\hline 336 & abr-07 & Rio claro & Não & Não & Não & Não & Não & Sim & Não & 1690 & 1999 & Não & sim & 11,0 & $\mathrm{Sim}$ & Não & Não & Não & Não & Não & sim & sim & sim & Não & sim \\
\hline 337 & mai-07 & Rio claro & Não & Não & Não & Não & Não & $\mathrm{Sim}$ & Não & 1690 & 1999 & Não & Sim & 11,0 & Não & Não & Não & Não & Não & Não & sim & sim & sim & Não & sim \\
\hline 338 & jun-07 & Rio claro & Não & Não & Não & Não & Não & Sim & Não & 1690 & 1999 & Não & sim & 11,0 & Não & Não & Não & Não & Não & Não & Sim & sim & Sim & Não & sim \\
\hline 339 & jul-07 & Rio claro & Não & Não & Não & Não & Não & Sim & Não & 1690 & 1999 & Não & Sim & 11,0 & Não & Não & Não & Não & Não & Não & Sim & sim & Sim & Não & Sim \\
\hline 340 & jul-07 & |Rio claro & Não & Não & Não & Não & Não & Não & Sim & 1690 & 1999 & Não & $\mathrm{Sim}$ & 11,0 & Não & Não & Não & Não & Não & Não & Sim & Sim & Não & Não & Não \\
\hline
\end{tabular}




\begin{tabular}{|c|c|c|c|c|c|c|c|c|c|c|c|c|c|c|c|c|c|c|c|c|c|c|c|c|c|}
\hline \multirow[b]{2}{*}{ ID } & \multirow[b]{2}{*}{$\begin{array}{l}\text { Data } \\
\text { Registro }\end{array}$} & \multirow{2}{*}{$\begin{array}{l}\text { IDENTIFICAÇĀo } \\
\text { Cidade }\end{array}$} & \multicolumn{7}{|c|}{ GERENC CONAMA / CETESB } & DADOS & O POSTO & & exto geoló & & FASE & APOR & FASE & RETIDA & & APL & Dis & iolv & & & \\
\hline & & & AvP & IC & ID & Artx & $\mathrm{PI}$ & REM & ME & $\begin{array}{c}\text { Área } \\
\mathrm{m} 2\end{array}$ & $\begin{array}{l}\text { Data } \\
\text { instala }\end{array}$ & Sed. & $\begin{array}{l}\text { Rocha } \\
\text { alterada }\end{array}$ & $\begin{array}{l}\text { ZN Sat } \\
\text { (m) }\end{array}$ & $\begin{array}{c}\text { Detectado } \\
?\end{array}$ & $\begin{array}{c}\text { Delimitado } \\
?\end{array}$ & $\begin{array}{c}\text { Detectado } \\
?\end{array}$ & $\begin{array}{c}\text { Delimitado } \\
?\end{array}$ & $\left|\begin{array}{c}\text { Detectado } \\
?\end{array}\right|$ & Delimit & $\begin{array}{c}\text { Detectado } \\
?\end{array}$ & $\begin{array}{c}\text { Delimitada } \\
?\end{array}$ & $\begin{array}{c}\text { Remediação } \\
\text { ? }\end{array}$ & $\begin{array}{c}\text { Remediação } \\
\text { Z Nsatu? }\end{array}$ & $\begin{array}{l}\text { Remediaçã } \\
\text { Z Sat? }\end{array}$ \\
\hline 341 & & Rio claro & Não & Não & Não & Não & Não & Não & Sim & 1690 & 1999 & Não & Sim & 10,5 & Não & Não & Não & Não & Não & Não & Sim & Sim & Não & Não & \\
\hline 342 & out-09 & Rio claro & Não & Não & Não & Não & Não & Não & sim & 1690 & 1999 & Não & Sim & 10,5 & Não & Não & Não & Não & Não & Não & Sim & sim & Não & Não & \\
\hline 343 & mar-10 & Rio claro & Não & Não & Não & Não & $\begin{array}{l}\text { Não } \\
\text { Nã }\end{array}$ & Não & Sim & 1690 & 1999 & $\begin{array}{l}\text { Não } \\
\text { Nầ }\end{array}$ & Sim & 10,5 & Não & $\begin{array}{l}\text { Não } \\
\text { Nâ }\end{array}$ & Não & Não & Não & Não & Sim & Sim & Não & Não & \\
\hline 344 & jul-10 & Rio claro & Não & Não & Não & Não & Não & Não & sim & 1690 & 1999 & Não & $\mathrm{Sim}$ & 10,5 & & & & & & & & sim & & & \\
\hline 345 & jun-10 & São Paulo & Não & Sim & Não & Não & Não & Não & Não & 1280 & 2002 & Sim & Não & 5,0 & Sim & Não & Sim & Não & Sim & Não & Sim & Não & & & \\
\hline 346 & jun-10 & São Paulo & Não & Não & Sim & Não & Não & Não & Não & 1280 & 2002 & Sim & Não & 5,0 & Sim & Não & Sim & Não & Não & Não & Sim & Não & & & \\
\hline 347 & dez-12 & $\begin{array}{l}\text { São Paulo } \\
\text { S̃̃ Pan }\end{array}$ & Não & Não & Não & Não & Não & Não & Sim & $\begin{array}{l}1280 \\
1280\end{array}$ & $\begin{array}{l}2002 \\
2002\end{array}$ & Sim & Não & 5,0 & Não & Não & Não & Não & Não & Não & Sim & Não & & & \\
\hline $\begin{array}{l}348 \\
349\end{array}$ & $\begin{array}{r}\text { abb-13 } \\
\text { jul-15 }\end{array}$ & $\begin{array}{l}\text { São Paulo } \\
\text { Sâo Paulo }\end{array}$ & $\begin{array}{l}\text { Não } \\
\text { Sim }\end{array}$ & $\begin{array}{l}\text { Não } \\
\text { Não }\end{array}$ & $\begin{array}{l}\text { Não } \\
\text { Não }\end{array}$ & $\begin{array}{l}\text { Não } \\
\text { Não }\end{array}$ & $\begin{array}{l}\text { Não } \\
\text { Não }\end{array}$ & $\begin{array}{l}\text { Não } \\
\text { Não }\end{array}$ & $\begin{array}{l}\text { Sim } \\
\text { Não }\end{array}$ & $\begin{array}{l}1280 \\
1280\end{array}$ & $\begin{array}{l}2002 \\
2002\end{array}$ & $\begin{array}{l}\text { Sim } \\
\text { Sim }\end{array}$ & $\begin{array}{l}\text { Não } \\
\text { Nâo }\end{array}$ & $\begin{array}{l}5,0 \\
50\end{array}$ & $\begin{array}{l}\text { Não } \\
\text { Não }\end{array}$ & $\begin{array}{l}\text { Não } \\
\text { Nâno }\end{array}$ & $\begin{array}{l}\text { Não } \\
\text { Não }\end{array}$ & $\begin{array}{l}\text { Não } \\
\text { Não }\end{array}$ & $\begin{array}{l}\text { Não } \\
\text { Nã }\end{array}$ & $\begin{array}{l}\text { Não } \\
\text { Não }\end{array}$ & Sim & Não & & & \\
\hline $\begin{array}{l}349 \\
350\end{array}$ & $\begin{array}{l}\text { uul-15 } \\
\text { jul-15 }\end{array}$ & $\begin{array}{l}\text { Sao Paaulo } \\
\text { são Paulo }\end{array}$ & $\begin{array}{l}\text { Sim } \\
\text { Não }\end{array}$ & $\begin{array}{l}\text { Não } \\
\text { Sim }\end{array}$ & $\begin{array}{l}\text { Não } \\
\text { Nâo }\end{array}$ & $\begin{array}{l}\text { Não } \\
\text { Nâo }\end{array}$ & $\begin{array}{l}\begin{array}{l}\text { Nâo } \\
\text { Nâo }\end{array}\end{array}$ & $\begin{array}{l}\text { Năo } \\
\text { Não }\end{array}$ & 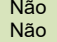 & $\begin{array}{l}1280 \\
1280\end{array}$ & $\begin{array}{l}2002 \\
2002\end{array}$ & $\begin{array}{l}\text { Sim } \\
\text { Sim }\end{array}$ & $\begin{array}{l}\text { Năo } \\
\text { Não }\end{array}$ & $\begin{array}{l}5,0 \\
5,0\end{array}$ & $\begin{array}{l}\text { Não } \\
\text { Nâo }\end{array}$ & $\begin{array}{l}\text { Não } \\
\text { Não }\end{array}$ & $\begin{array}{l}\text { Não } \\
\text { Não }\end{array}$ & $\begin{array}{l}\text { Não } \\
\text { Não }\end{array}$ & $\begin{array}{l}\text { Não } \\
\text { Não }\end{array}$ & $\begin{array}{l}\text { Não } \\
\text { Não }\end{array}$ & Sim & $\begin{array}{l}\text { Não } \\
\text { Não }\end{array}$ & & & \\
\hline 351 & fev-16 & São Paulo & Não & Não & Não & Não & Não & Sim & Não & 1280 & 2002 & sim & Não & 4,2 & Não & Não & Não & Não & Não & Não & & Não & Sim & Sim & \\
\hline 352 & jan-17 & São Paulo & Não & Não & Sim & Não & Não & Não & Não & 1280 & 2002 & Sim & Não & 4,2 & Não & Não & Não & Não & Não & Não & Sim & Não & & & \\
\hline 353 & mar-17 & $\begin{array}{l}\text { São Paulo } \\
\text { Limeira }\end{array}$ & Não & Não & Não & Sim & Não & Não & Sim & 1280 & 2002 & Sim & Não & 4,2 & Não & Não & Não & Não & Não & Não & Sim & Não & & & \\
\hline $\begin{array}{l}354 \\
355\end{array}$ & $\begin{array}{r}\text { fev-05 } \\
\text { mai-05 }\end{array}$ & $\begin{array}{l}\text { Limeira } \\
\text { Limeira }\end{array}$ & $\begin{array}{l}\text { Não } \\
\text { Não }\end{array}$ & $\begin{array}{l}\text { Sim } \\
\text { Sim }\end{array}$ & $\begin{array}{l}\text { Não } \\
\text { Năo }\end{array}$ & $\begin{array}{l}\text { Não } \\
\text { Não }\end{array}$ & $\begin{array}{l}\text { Não } \\
\text { Não }\end{array}$ & $\begin{array}{l}\text { Sim } \\
\text { Não }\end{array}$ & $\begin{array}{l}\text { Não } \\
\text { Não }\end{array}$ & $\begin{array}{l}2000 \\
2000\end{array}$ & $\begin{array}{l}2002 \\
2002\end{array}$ & $\begin{array}{l}\text { Sim } \\
\text { Sim }\end{array}$ & $\begin{array}{l}\text { Não } \\
\text { Năo }\end{array}$ & $\begin{array}{l}7,5 \\
7,5\end{array}$ & & & & & & & & & Sim & Sim & \\
\hline $\begin{array}{l}355 \\
356\end{array}$ & $\begin{array}{c}\text { mal-05 } \\
\text { mar-06 }\end{array}$ & $\begin{array}{l}\begin{array}{l}\text { imeira } \\
\text { Limeira }\end{array} \\
\text { aimeirat }\end{array}$ & $\begin{array}{l}\text { Não } \\
\text { Não }\end{array}$ & $\begin{array}{l}\text { Sim } \\
\text { Não }\end{array}$ & $\begin{array}{l}\text { Não } \\
\text { Sim }\end{array}$ & $\begin{array}{l}\text { Não } \\
\text { Não }\end{array}$ & $\begin{array}{l}\text { Não } \\
\text { Não }\end{array}$ & $\begin{array}{l}\text { Não } \\
\text { Não }\end{array}$ & $\begin{array}{l}\text { Não } \\
\text { Não }\end{array}$ & $\begin{array}{l}2000 \\
2000\end{array}$ & $\begin{array}{l}2002 \\
2002\end{array}$ & $\begin{array}{l}\text { Sim } \\
\text { Sim }\end{array}$ & $\begin{array}{l}\text { Não } \\
\text { Não }\end{array}$ & $\begin{array}{l}7,5 \\
7,5\end{array}$ & Não & Não & $\begin{array}{l}\text { Não } \\
\text { Não }\end{array}$ & $\begin{array}{l}\text { Não } \\
\text { Não }\end{array}$ & $\begin{array}{l}\text { Não } \\
\text { Năo }\end{array}$ & $\begin{array}{l}\text { Não } \\
\text { Não }\end{array}$ & Sim & $\begin{array}{l}\text { Não } \\
\text { Sim }\end{array}$ & & & \\
\hline $\begin{array}{l}356 \\
357\end{array}$ & $\begin{array}{c}m \text { mar-06 } \\
\text { jun-06 }\end{array}$ & $\begin{array}{l}\text { Limeira } \\
\text { Limeira }\end{array}$ & $\begin{array}{l}\text { Não } \\
\text { Nâo }\end{array}$ & $\begin{array}{l}\text { Nầ } \\
\text { Não }\end{array}$ & $\begin{array}{l}\text { Sim } \\
\text { Não }\end{array}$ & $\begin{array}{l}\text { Nâo } \\
\text { Sim }\end{array}$ & $\begin{array}{l}\text { Nâo } \\
\text { Não }\end{array}$ & 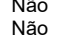 & 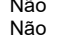 & $\begin{array}{l}2000 \\
2000\end{array}$ & $\begin{array}{l}2002 \\
2002\end{array}$ & $\begin{array}{l}\text { Sim } \\
\text { Sim }\end{array}$ & $\begin{array}{l}\text { Năo } \\
\text { Não }\end{array}$ & $\begin{array}{l}7,5 \\
7,5\end{array}$ & & & $\begin{array}{l}\text { Náo } \\
\text { Sim }\end{array}$ & $\begin{array}{l}\text { Não } \\
\text { Sim }\end{array}$ & $\begin{array}{l}\text { Não } \\
\text { Não }\end{array}$ & $\begin{array}{l}\text { Não } \\
\text { Não }\end{array}$ & $\begin{array}{l}\text { Sim } \\
\text { Sim }\end{array}$ & $\begin{array}{l}\text { Sim } \\
\text { Sim }\end{array}$ & & & \\
\hline 358 & mai-07 & Limeira & Não & Não & Não & Não & Sim & $\begin{array}{l}\text { Não } \\
\text { Nân }\end{array}$ & Não & 2000 & 2002 & Sim & Não & 7,5 & Sim & Sim & & & & & Sim & & & & \\
\hline 359 & ago-07 & Limeira & Não & Não & Não & Não & Não & Sim & Não & 2000 & 2002 & Sim & Não & 7,5 & $\mathrm{Sim}$ & Sim & & & Sim & Sim & Sim & & Sim & Sim & sim \\
\hline 360 & set-07 & Limeira & Não & Não & Não & Não & Não & Sim & Não & 2000 & 2002 & Sim & Não & 7,5 & Sim & Sim & & & Sim & Sim & Sim & & sim & Sim & sim \\
\hline 361 & nov-07 & Limeira & Não & Não & Não & Não & Não & Sim & Não & 2000 & 2002 & Sim & Não & 7,5 & Sim & Sim & & & Sim & sim & Sim & & Sim & Sim & Sim \\
\hline 362 & fev-08 & Limeira & Não & Não & Não & Não & Não & Sim & Não & 2000 & 2002 & Sim & Não & 7,5 & Sim & sim & & & Sim & Sim & sim & & Sim & sim & Sim \\
\hline 363 & mar-08 & Limeira & Não & Não & Não & Não & Não & Sim & Não & 2000 & 2002 & Sim & Não & 7,5 & sim & sim & & & sim & Sim & sim & & Sim & Sim & sim \\
\hline 364 & mar-08 & Limeira & Não & Não & Não & Não & Não & Sim & Não & 2000 & 2002 & Sim & Não & 7,5 & Sim & Sim & & & Sim & Sim & Sim & & Sim & Sim & Sim \\
\hline 365 & jun-08 & Limeira & Não & Não & Não & Não & Não & Sim & Não & 2000 & 2002 & Sim & Não & 7,5 & Sim & Sim & & & Sim & Sim & Sim & & Sim & Sim & Sim \\
\hline 366 & $\begin{array}{r}\text { jul-08 } \\
0070\end{array}$ & Limeira & Não & Não & Não & Não & Não & Sim & Não & 2000 & 2002 & Sim & Não & 7,5 & Sim & Sim & & & & & & & & & \\
\hline 367 & dez-08 & Limeira & Não & Não & Não & $\begin{array}{l}\text { Não } \\
\text { N20ี }\end{array}$ & Não & Sim & Não & 2000 & 2002 & Sim & Não & & Sim & Sim & & & Sim & Sim & Sim & & sim & Sim & sim \\
\hline $\begin{array}{l}368 \\
369\end{array}$ & $\begin{array}{c}\text { jun-09 } \\
\text { nov-09 }\end{array}$ & $\begin{array}{l}\text { Limeira } \\
\text { Limeira }\end{array}$ & $\begin{array}{l}\text { Não } \\
\text { Não }\end{array}$ & $\begin{array}{l}\text { Não } \\
\text { Não }\end{array}$ & $\begin{array}{l}\text { Não } \\
\text { Năo }\end{array}$ & $\begin{array}{l}\text { Não } \\
\text { Não }\end{array}$ & $\begin{array}{l}\text { Não } \\
\text { Não }\end{array}$ & $\begin{array}{l}\text { Sim } \\
\text { Sim }\end{array}$ & $\begin{array}{l}\text { Não } \\
\text { Não }\end{array}$ & $\begin{array}{l}2000 \\
2000\end{array}$ & $\begin{array}{l}2002 \\
2002\end{array}$ & $\begin{array}{l}\text { Sim } \\
\text { Sim }\end{array}$ & $\begin{array}{l}\text { Não } \\
\text { Năo }\end{array}$ & & $\begin{array}{l}\text { Sim } \\
\text { Sim }\end{array}$ & $\begin{array}{l}\text { Sim } \\
\text { Sim }\end{array}$ & & & $\begin{array}{l}\text { Sim } \\
\text { Sim }\end{array}$ & $\begin{array}{l}\text { Sim } \\
\text { Sim }\end{array}$ & $\begin{array}{l}\text { Sim } \\
\text { Sim }\end{array}$ & & $\begin{array}{l}\text { Sim } \\
\text { Sim }\end{array}$ & $\begin{array}{l}\text { Sim } \\
\text { Sim }\end{array}$ & $\begin{array}{l}\text { Sim } \\
\text { Sim }\end{array}$ \\
\hline $\begin{array}{l}369 \\
370\end{array}$ & ago-10 & $\begin{array}{l}\text { Limeira } \\
\text { Limeira }\end{array}$ & $\begin{array}{l}\text { Não } \\
\text { Não }\end{array}$ & $\begin{array}{l}\text { Não } \\
\text { Não }\end{array}$ & $\begin{array}{l}\text { Nâo } \\
\text { Sim }\end{array}$ & $\begin{array}{l}\text { Năo } \\
\text { Não }\end{array}$ & $\begin{array}{l}\begin{array}{l}\text { Não } \\
\text { Não }\end{array} \\
\text { na }\end{array}$ & $\begin{array}{l}\text { Sim } \\
\text { Não }\end{array}$ & $\begin{array}{l}\text { Nâo } \\
\text { Não }\end{array}$ & $\begin{array}{l}2000 \\
2000\end{array}$ & $\begin{array}{l}2002 \\
2002\end{array}$ & $\begin{array}{l}\text { Sim } \\
\text { Sim }\end{array}$ & $\begin{array}{l}\text { Não } \\
\text { Não }\end{array}$ & & $\begin{array}{l}\text { Sim } \\
\text { Sim }\end{array}$ & $\begin{array}{l}\text { Sim } \\
\text { Sim }\end{array}$ & & & $\begin{array}{l}\text { Sim } \\
\text { Não }\end{array}$ & Nầ & Sim & & Sim & Sim & Sim \\
\hline 371 & nov-10 & $\begin{array}{l}\text { Lmeira } \\
\text { Limeira }\end{array}$ & $\begin{array}{l}\text { Nao } \\
\text { Não }\end{array}$ & $\begin{array}{l}\text { Nao } \\
\text { Não }\end{array}$ & Sim & $\begin{array}{l}\text { Nao } \\
\text { Sim }\end{array}$ & $\begin{array}{l}\text { Nao } \\
\text { Sim }\end{array}$ & $\begin{array}{l}\text { Nao } \\
\text { Não }\end{array}$ & $\begin{array}{l}\text { Nao } \\
\text { Não }\end{array}$ & 2000 & 2002 & Sim & Não & 7.8 & $\mathrm{Sim}$ & $\mathrm{Sim}$ & & & Sim & Sim & sim & & $\mathrm{Sim}$ & $\mathrm{Sim}$ & Sim \\
\hline 372 & jun-11 & Limeira & $\begin{array}{l}\text { Não } \\
\text { Não }\end{array}$ & Não & Não & Não & Não & $\begin{array}{l}\text { Nao } \\
\text { Sim }\end{array}$ & Não & 2000 & 2002 & sim & $\begin{array}{l}\text { Nao } \\
\text { Não }\end{array}$ & 7,8 & $\mathrm{Sim}$ & sim & & & sim & sim & sim & & Sim & Sim & $\mathrm{Sim}$ \\
\hline 373 & ago-11 & Limeira & Não & Não & Sim & Não & Não & Não & Sim & 2000 & 2002 & Sim & Não & 7,8 & Sim & Sim & Sim & Sim & Sim & Sim & Sim & & & & \\
\hline 374 & out-11 & Limeira & Não & Não & Não & Não & Não & Sim & Sim & 2000 & 2002 & Sim & Não & 7,8 & Sim & Sim & Sim & Sim & Não & Não & Sim & & & & \\
\hline 375 & jan-04 & Salto & Sim & Sim & Não & Não & Não & Não & Não & 3000 & 2000 & Sim & Não & 7,5 & & & & & & & & & & & \\
\hline 376 & mar-04 & Salto & Não & Não & Não & Não & Não & Sim & Não & 3000 & 2000 & Sim & Sim & 7,5 & & & & & & & & & Sim & Sim & \\
\hline 377 & mar-07 & Salto & Não & Não & Sim & Sim & Não & Não & Sim & 3000 & 2000 & Sim & Sim & 7,5 & Não & Não & & & Não & Não & Sim & & & & \\
\hline 378 & mar-04 & São Paulo & Sim & Sim & Não & Não & Não & Não & Não & 600 & 1972 & Sim & Não & 8,2 & Sim & Não & Sim & Não & Sim & Não & Sim & Não & & & \\
\hline 379 & abr-04 & São Paulo & Não & Não & Sim & Sim & Não & Não & Não & 600 & 1972 & Sim & Não & 8,2 & Sim & Sim & Sim & Sim & Sim & Sim & Sim & Sim & Não & Não & Não \\
\hline 380 & jul-04 & São Paulo & Não & Não & Não & Não & Não & Sim & Não & 600 & 1972 & sim & Não & 6,7 & sim & sim & Sim & Sim & Sim & Sim & Sim & sim & Sim & Sim & Sim \\
\hline 381 & abr-04 & São Paulo & Não & Não & Não & Não & Não & Sim & Não & 600 & 1972 & Sim & Não & 6,7 & Sim & Sim & & & & & Sim & Sim & & & \\
\hline 382 & mai-04 & São Paulo & Não & Não & Não & Não & Não & Sim & Não & 600 & 1972 & sim & Não & 6,7 & sim & sim & & & & & sim & sim & & & \\
\hline 383 & jun-04 & São Paulo & Não & Não & Não & Não & Não & Sim & Não & 600 & 1972 & Sim & Não & 6,7 & Sim & sim & & & & & sim & sim & & & \\
\hline 384 & & São Paulo & Não & Não & Não & Não & Não & Sim & Não & 600 & 1972 & Sim & Não & 6,7 & Sim & Sim & & & & & Sim & Sim & & & \\
\hline 385 & ago-04 & São Paulo & Não & Não & Não & Não & Não & Sim & Não & 600 & 1972 & Sim & Não & 6,7 & Sim & Sim & & & & & Sim & Sim & & & \\
\hline 386 & $\begin{array}{r}\text { set-04 } \\
\text { out-04 }\end{array}$ & $\begin{array}{l}\text { São Paulo } \\
\text { São Paulo }\end{array}$ & Não & Não & $\begin{array}{l}\text { Não } \\
\text { Não }\end{array}$ & $\begin{array}{l}\text { Não } \\
\text { Nãon }\end{array}$ & $\begin{array}{l}\text { Não } \\
\text { Nân }\end{array}$ & Sim & $\begin{array}{l}\text { Não } \\
\text { Não }\end{array}$ & $\begin{array}{l}600 \\
600\end{array}$ & $\begin{array}{l}1972 \\
1972\end{array}$ & Sim & $\begin{array}{l}\text { Não } \\
\text { Não }\end{array}$ & $\begin{array}{l}6,7 \\
67\end{array}$ & Sim & Sim & & & & & Sim & Sim & & & \\
\hline $\begin{array}{l}387 \\
388\end{array}$ & $\begin{array}{c}\text { out-044 } \\
\text { nov-04 }\end{array}$ & $\begin{array}{l}\text { Säo Paulo } \\
\text { São Paulo }\end{array}$ & $\begin{array}{l}\text { Não } \\
\text { Não }\end{array}$ & $\begin{array}{l}\text { Não } \\
\text { Não }\end{array}$ & $\begin{array}{l}\text { Não } \\
\text { Não }\end{array}$ & $\begin{array}{l}\text { Não } \\
\text { Não }\end{array}$ & $\begin{array}{l}\text { Não } \\
\text { Não }\end{array}$ & $\begin{array}{l}\text { Sim } \\
\text { sim }\end{array}$ & $\begin{array}{l}\text { Não } \\
\text { Não }\end{array}$ & $\begin{array}{l}600 \\
600\end{array}$ & $\begin{array}{l}1972 \\
1972\end{array}$ & $\begin{array}{l}\text { Sim } \\
\text { Sim }\end{array}$ & $\begin{array}{l}\text { Não } \\
\text { Não }\end{array}$ & $\begin{array}{l}6,7 \\
67\end{array}$ & $\begin{array}{l}\text { Sim } \\
\text { Sim }\end{array}$ & $\begin{array}{l}\text { Sim } \\
\text { Sim }\end{array}$ & & & & & Sim & Sim & & & \\
\hline $\begin{array}{l}388 \\
389\end{array}$ & $\begin{array}{r}\text { nov-04 } \\
\text { dez-04 }\end{array}$ & $\begin{array}{l}\text { São Paulo } \\
\text { São Paulo }\end{array}$ & $\begin{array}{l}\text { Não } \\
\text { Não }\end{array}$ & $\begin{array}{l}\text { Não } \\
\text { Não }\end{array}$ & $\begin{array}{l}\text { Não } \\
\text { Năo }\end{array}$ & $\begin{array}{l}\text { Não } \\
\text { Não }\end{array}$ & $\begin{array}{l}\text { Não } \\
\text { Năo }\end{array}$ & $\begin{array}{l}\text { Sim } \\
\text { Sim }\end{array}$ & $\begin{array}{l}\text { Não } \\
\text { Não }\end{array}$ & $\begin{array}{l}600 \\
600\end{array}$ & $\begin{array}{l}1972 \\
1972\end{array}$ & $\begin{array}{l}\text { Sim } \\
\text { Sim }\end{array}$ & $\begin{array}{l}\text { Não } \\
\text { Năo }\end{array}$ & $\begin{array}{l}6,7 \\
6,7\end{array}$ & $\begin{array}{l}\text { Sim } \\
\text { Sim }\end{array}$ & $\begin{array}{l}\text { Sim } \\
\text { Sim }\end{array}$ & & & & & $\begin{array}{l}\text { Sim } \\
\text { Sim }\end{array}$ & $\begin{array}{l}\text { Sim } \\
\text { Sim }\end{array}$ & & & \\
\hline 390 & jan-05 & $\begin{array}{l}\text { São Paulo } \\
\text { Salo }\end{array}$ & $\begin{array}{l}\text { Não } \\
\text { Não }\end{array}$ & $\begin{array}{l}\text { Nao } \\
\text { Não }\end{array}$ & $\begin{array}{l}\text { Nao } \\
\text { Não }\end{array}$ & $\begin{array}{l}\text { Nao } \\
\text { Não }\end{array}$ & $\begin{array}{l}\begin{array}{l}\text { Nao } \\
\text { Não }\end{array} \\
\text { na }\end{array}$ & $\begin{array}{l}\text { Sim } \\
\text { Sim }\end{array}$ & $\begin{array}{l}\text { Nao } \\
\text { Nãoo }\end{array}$ & 600 & $\begin{array}{l}1972 \\
1972\end{array}$ & $\begin{array}{l}\text { Sim } \\
\text { Sim }\end{array}$ & $\begin{array}{l}\text { Não } \\
\text { Não }\end{array}$ & $\begin{array}{l}6,1 \\
6,7\end{array}$ & $\begin{array}{l}\text { Sim } \\
\text { Sim }\end{array}$ & $\begin{array}{l}\text { Sim } \\
\text { Sim }\end{array}$ & & & & & sim & sim & & & \\
\hline 391 & mai-05 & São Paulo & $\begin{array}{l}\text { Nao } \\
\text { Não }\end{array}$ & $\begin{array}{l}\text { Nao } \\
\text { Não }\end{array}$ & $\begin{array}{l}\text { Nao } \\
\text { Sim }\end{array}$ & $\begin{array}{l}\text { Nao } \\
\text { Não }\end{array}$ & $\begin{array}{l}\text { Nao } \\
\text { Não }\end{array}$ & $\begin{array}{l}\text { Nấ } \\
\text { Nấ }\end{array}$ & Sim & 600 & 1972 & sim & $\begin{array}{l}\text { Nao } \\
\text { Não }\end{array}$ & 6,7 & $\mathrm{Sim}$ & Sim & & & & & sim & sim & & & \\
\hline 392 & mai-05 & São Paulo & Não & Não & Não & Sim & Não & Não & Sim & 600 & 1972 & Sim & Não & 6,7 & & & & & & & Sim & Sim & & & \\
\hline 393 & fev-03 & São Paulo & Sim & Sim & Não & Não & Não & Não & Nẫo & 2700 & 1971 & Sim & Não & 0,9 & Sim & Sim & Sim & Não & Não & Não & sim & Nâo & & & \\
\hline 394 & jul-04 & São Paulo & Não & Não & Não & Não & Não & Sim & Não & 2700 & 1971 & Sim & Não & 0,9 & & & & & & & & & Sim & Sim & \\
\hline 395 & set & São Paulo & Não & Não & Sim & Não & Não & Nāo & Não & 2700 & 1971 & sim & Não & 0,9 & Sim & Não & Não & Não & Sim & Sim & & & & & \\
\hline 396 & fev-07 & São Paulo & Não & Não & Não & Não & Não & Sim & $\mathrm{N}$ & 2700 & 1971 & Sim & Não & & Sim & Sim & & & & & & & Sim & & Sim \\
\hline 397 & mar-07 & São Paulo & Não & Não & Não & Não & Não & sim & $\mathrm{N}$ & 27 & 1971 & Sim & Não & & Sim & Sim & & & Sim & Sim & & & & & \\
\hline 398 & mar-07 & São Paulo & Não & Não & Sim & Sim & Não & Não & $\mathrm{N}$ & 27 & $\begin{array}{l}1971 \\
1071\end{array}$ & Sim & Não & & Sim & Sim & & & Sim & Sim & & & & & \\
\hline 399 & $\begin{array}{r}\text { abr-07 } \\
\text { mai-07 }\end{array}$ & $\begin{array}{l}\begin{array}{l}\text { São Paulo } \\
\text { São Paulo }\end{array}\end{array}$ & Não & Não & Não & Não & Não & Não & Sim & $\begin{array}{r}2700 \\
2700\end{array}$ & 1971 & Sim & Não & 0,9 & Sim & Sim & Sim & Não & & & sim & sim & & & \\
\hline $\begin{array}{l}400 \\
401\end{array}$ & $\begin{array}{l}\text { mal-u } \\
\text { fev-08 }\end{array}$ & $\begin{array}{l}\text { Säo Paulo } \\
\text { São Paulo }\end{array}$ & $\begin{array}{l}\text { Não } \\
\text { Não }\end{array}$ & $\begin{array}{l}\text { Não } \\
\text { Não }\end{array}$ & $\begin{array}{l}\text { Sim } \\
\text { Não }\end{array}$ & $\begin{array}{l}\text { Sim } \\
\text { Não }\end{array}$ & $\begin{array}{l}\text { Não } \\
\text { Não }\end{array}$ & $\begin{array}{l}\text { Não } \\
\text { Sim }\end{array}$ & $\begin{array}{l}\text { Não } \\
\text { Não }\end{array}$ & $\begin{array}{l}2700 \\
2700\end{array}$ & $\begin{array}{l}1971 \\
1971\end{array}$ & $\begin{array}{l}\text { Sim } \\
\text { Sim }\end{array}$ & $\begin{array}{l}\text { Não } \\
\text { Nẫo }\end{array}$ & $\begin{array}{l}0,9 \\
0,9\end{array}$ & $\begin{array}{l}\text { Sim } \\
\text { Sim }\end{array}$ & $\begin{array}{l}\text { Sim } \\
\text { Sim }\end{array}$ & Sim & Năo & $\begin{array}{l}\text { Não } \\
\text { Sim }\end{array}$ & $\begin{array}{l}\text { Não } \\
\text { Sim }\end{array}$ & Sim & Sim & sim & Sim & sim \\
\hline 402 & $\begin{array}{l}\text { fev-08 } \\
\text { for }\end{array}$ & $\begin{array}{l}\text { São Paulo } \\
\text { Sât }\end{array}$ & Não & Não & Não & Não & Não & Sim & Não & 2700 & 1971 & Sim & Não & & Sim & Sim & & & Sim & Sim & & & Sim & Sim & Sim \\
\hline 403 & mar-08 & $\begin{array}{l}\text { são Pau } \\
\text { sol }\end{array}$ & Não & Não & Não & Não & Não & Sim & $\mathrm{N} \hat{\mathrm{c}}$ & 27 & 1971 & Sim & Não & & Sim & Sim & & & Sim & & & & im & Sim & Sim \\
\hline 404 & abr-08 & São Paulo & Não & Não & Não & Não & Não & Sim & Nà & & 197 & & Não & & Sim & $\mathrm{Si}$ & & & Sim & s & & & sim & Sim & sim \\
\hline 405 & jul-08 & São Paulo & Não & Não & Não & Não & Não & Sim & Não & 2700 & 1971 & Sim & Não & & Sim & Sim & & & Sim & Sim & & & Sim & sim & sim \\
\hline 406 & ago-08 & São Paulo & Não & Não & Não & Não & Não & Sim & Não & 2700 & 1971 & Sim & Não & & Sim & Sim & & & Sim & Sim & & & Sim & Sim & Sim \\
\hline 407 & set-08 & São Paulo & Não & Não & Não & Não & Não & sim & Não & 2700 & 1971 & Sim & Não & & Sim & Sim & & & Sim & Sim & & & Sim & Sim & Sim \\
\hline 408 & | nov-08 & São Paulo & Não & Não & Não & Não & Não & Sim & Não & 2700 & 1971 & Sim & Não & & Sim & Sim & & & Sim & Sim & & & Sim & Sim & Sim \\
\hline
\end{tabular}




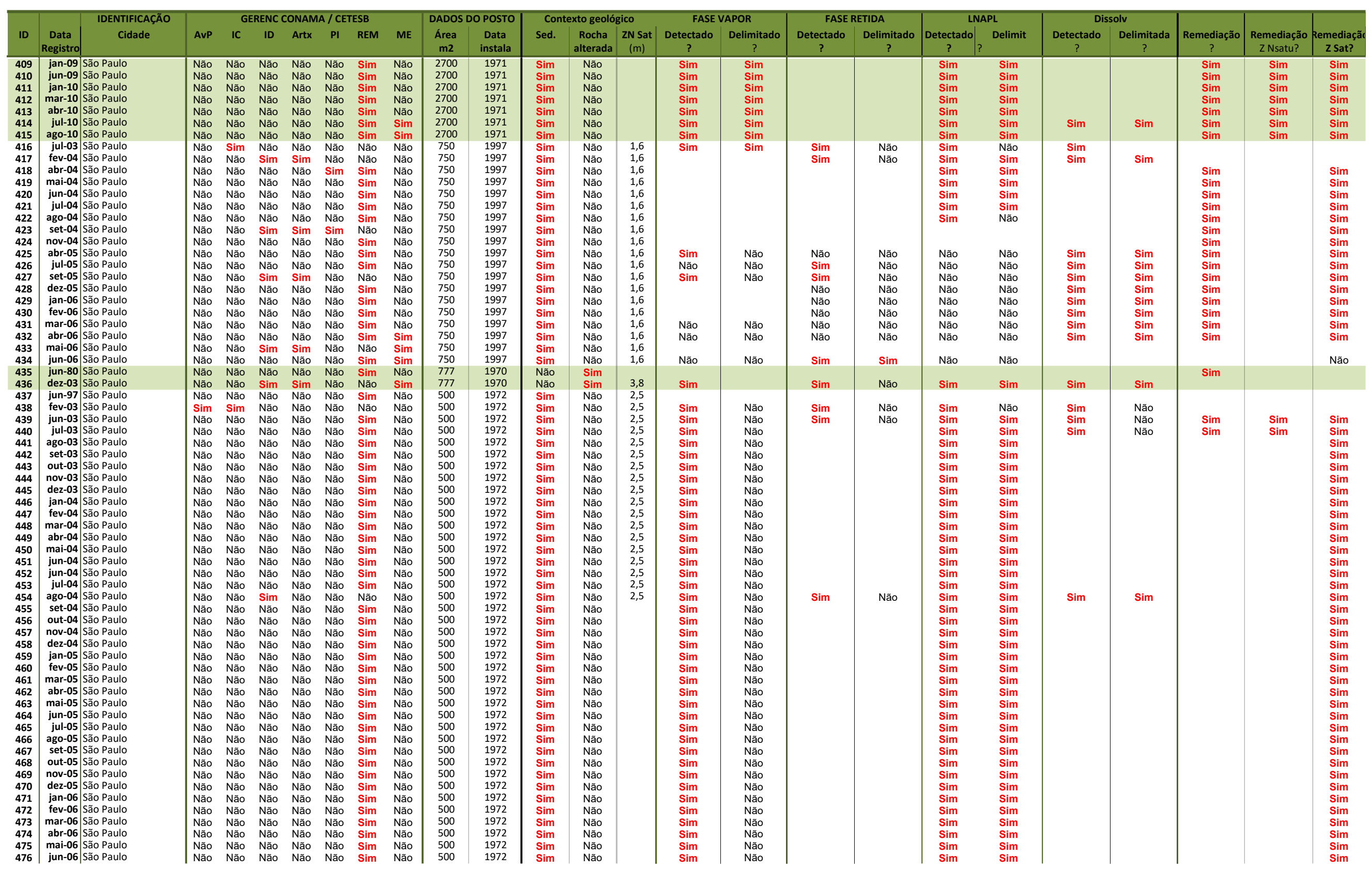




\begin{tabular}{|c|c|c|c|c|c|c|c|c|c|c|c|c|c|c|c|c|c|c|c|c|c|c|c|c|c|}
\hline \multirow[b]{2}{*}{ ID } & \multirow[b]{2}{*}{\begin{tabular}{|r|} 
Data \\
Registro
\end{tabular}} & \multirow{2}{*}{$\begin{array}{l}\text { IDENTIFICAÇÃO } \\
\text { Cidade }\end{array}$} & \multicolumn{7}{|c|}{ GERENC CONAMA / CETESB } & DADOS & O POSTO & Con & exto geológ & & FASE & APOR & FASE $\mathrm{F}$ & ETIDA & LN & APL & Dis & iolv & & & \\
\hline & & & AvP & IC & ID & Artx & PI & REM & ME & $\begin{array}{c}\text { Área } \\
\text { m2 }\end{array}$ & $\begin{array}{l}\text { Data } \\
\text { instala }\end{array}$ & Sed. & \begin{tabular}{|c|} 
Rocha \\
alterada
\end{tabular} & $\begin{array}{c}\text { ZN Sat } \\
\text { (m) }\end{array}$ & $\begin{array}{c}\text { Detectado } \\
?\end{array}$ & $\begin{array}{c}\text { Delimitado } \\
?\end{array}$ & $\begin{array}{c}\text { Detectado } \\
?\end{array}$ & $\begin{array}{c}\text { Delimitado } \\
?\end{array}$ & $\begin{array}{c}\text { Detectado } \\
?\end{array} ?$ & Delimit & $\begin{array}{c}\text { Detectado } \\
?\end{array}$ & $\begin{array}{c}\text { Delimitada } \\
?\end{array}$ & $\mid \begin{array}{c}\text { Remediação } \\
?\end{array}$ & \begin{tabular}{|} 
Remediação \\
Z Nsatu?
\end{tabular} & $\begin{array}{l}\text { Remediaçã } \\
\text { Z Sat? }\end{array}$ \\
\hline 477 & jul-06 & São Paulo & Não & Não & Não & Não & Não & Sim & Não & 500 & 1972 & Sim & \begin{tabular}{|l|} 
Não \\
\end{tabular} & & Sim & Não & & & Sim & Sim & & & & & Sim \\
\hline $\begin{array}{l}478 \\
479\end{array}$ & \begin{tabular}{|l|} 
ago-06 \\
set-06
\end{tabular} & $\begin{array}{l}\text { São Paulo } \\
\text { São Paulo }\end{array}$ & $\begin{array}{l}\text { Não } \\
\text { Não }\end{array}$ & $\begin{array}{l}\text { Não } \\
\text { Não }\end{array}$ & 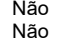 & $\begin{array}{l}\text { Não } \\
\text { Não }\end{array}$ & $\begin{array}{l}\text { Não } \\
\text { Não }\end{array}$ & $\underset{\text { Sim }}{\operatorname{Sim}}$ & $\begin{array}{l}\text { Não } \\
\text { Não }\end{array}$ & $\begin{array}{l}500 \\
500\end{array}$ & $\begin{array}{l}1972 \\
1972\end{array}$ & $\begin{array}{l}\text { Sim } \\
\text { Sim }\end{array}$ & $\begin{array}{l}\text { Não } \\
\text { Não }\end{array}$ & & $\begin{array}{l}\text { Sim } \\
\text { Sim }\end{array}$ & $\begin{array}{l}\text { Não } \\
\text { Não }\end{array}$ & & & $\begin{array}{l}\text { Sim } \\
\text { Sim }\end{array}$ & $\begin{array}{l}\text { Sim } \\
\text { Sim }\end{array}$ & & & & & $\begin{array}{l}\text { Sim } \\
\text { Sim }\end{array}$ \\
\hline 480 & out-06 & São Paulo & Não & Não & Não & Não & Não & Sim & Não & 500 & 1972 & Sim & Não & & Sim & Não & & & Sim & Sim & & & & & Sim \\
\hline 481 & nov-06 & São Paulo & Não & Não & Não & Não & Não & Sim & Não & 500 & 1972 & Sim & Não & & Sim & Não & & & Sim & Sim & & & & & Sim \\
\hline 482 & dez-06 & São Paulo & Não & Não & Não & Não & Não & Sim & Não & $\begin{array}{c}500 \\
13250\end{array}$ & 1972 & sim & Não & & Sim & Não & & & $\operatorname{Sim}$ & $\operatorname{sim}$ & & & & & \\
\hline 483 & $\mid \begin{array}{l}\text { jul-07 } \\
\text { jutto. }\end{array}$ & Mogi das Cruzes & Não & Sim & Sim & Sim & Não & Não & Não & $\begin{array}{l}13250 \\
13250\end{array}$ & 1997 & $\operatorname{Sim}_{\text {Sim }}$ & Não & 1,9 & Não & Não & Sim & Não & Não & Não & Sim & Não & & & \\
\hline $\begin{array}{l}484 \\
485\end{array}$ & $\mid$\begin{tabular}{|c|} 
outt-07 \\
abr-08
\end{tabular} & $\begin{array}{l}\text { Mogi das Cruzzes } \\
\text { Mogi das Cruzes }\end{array}$ & $\begin{array}{l}\text { Não } \\
\text { Não }\end{array}$ & $\begin{array}{l}\text { Não } \\
\text { Não }\end{array}$ & $\begin{array}{l}\text { Não } \\
\text { Sim }\end{array}$ & $\begin{array}{l}\text { Não } \\
\text { Sim }\end{array}$ & $\begin{array}{l}\text { Não } \\
\text { Não }\end{array}$ & Sim & $\begin{array}{l}\text { Não } \\
\text { Não }\end{array}$ & $\begin{array}{l}13250 \\
13250\end{array}$ & $\begin{array}{l}1997 \\
1997\end{array}$ & Sim & $\begin{array}{l}\text { Não } \\
\text { Nâo }\end{array}$ & $\begin{array}{l}1,9 \\
1,9\end{array}$ & & & & & & & $\operatorname{sim}$ & & Sim & & \\
\hline $\begin{array}{l}485 \\
486\end{array}$ & $\begin{array}{l}\text { arov-0 } \\
\text { nov-09 }\end{array}$ & Mogi das Cruzes & $\begin{array}{l}\text { Noo } \\
\text { Não }\end{array}$ & $\begin{array}{l}\text { Noo } \\
\text { Não }\end{array}$ & $\begin{array}{l}\text { Sim } \\
\text { Sim }\end{array}$ & $\begin{array}{l}\text { Sim } \\
\text { Sim }\end{array}$ & $\begin{array}{l}\text { Não } \\
\text { Não }\end{array}$ & $\begin{array}{l}\text { Não } \\
\text { Não }\end{array}$ & $\begin{array}{l}\text { Não } \\
\text { Não }\end{array}$ & $\begin{array}{l}13250 \\
13250\end{array}$ & $\begin{array}{l}1997 \\
1997\end{array}$ & $\begin{array}{l}\text { Sim } \\
\text { Sim }\end{array}$ & $\begin{array}{l}\text { Não } \\
\text { Não }\end{array}$ & $\begin{array}{l}1,9 \\
2,0\end{array}$ & $\begin{array}{l}\text { Não } \\
\text { Não }\end{array}$ & $\begin{array}{l}\text { Não } \\
\text { Não }\end{array}$ & $\mathrm{Sim}_{\mathrm{Sim}}$ & $\begin{array}{l}\text { Não } \\
\text { Sim }\end{array}$ & Sim & & $\underset{S i m}{S i m}$ & $\begin{array}{l}\text { Não } \\
\text { Sim }\end{array}$ & & & \\
\hline 487 & ago-10 & Mogi das Cruzes & Não & Não & Nâo & Não & Sim & Sim & Não & 13250 & 1997 & Sim & $\begin{array}{l}\text { Nao } \\
\text { Não }\end{array}$ & 2,0 & Não & Não & Sim & Sim & Sim & $\mathrm{Sim}$ & Sim & Sim & & & \\
\hline 488 & \begin{tabular}{|l|} 
set-10 \\
\end{tabular} & Mogi das Cruzes & Não & Não & Não & Não & Não & Sim & Não & 13250 & 1997 & Sim & Não & & Não & Não & & & Sim & Sim & & & Sim & Sim & Sim \\
\hline 489 & nov-10 & Mogi das Cruzes & Não & Não & Não & Não & Não & Sim & Não & $\begin{array}{l}13250 \\
13250\end{array}$ & 1997 & Sim & Não & & & & & & Sim & Sim & & & Sim & Sim & \\
\hline 490 & \begin{tabular}{|l|} 
jun-11 \\
\end{tabular} & Mogi das Cruzes & Não & Não & Não & Não & Não & Sim & Não & 13250 & 1997 & Sim & Não & & & & & & Sim & Sim & & & Sim & Sim & \\
\hline 492 & $\begin{array}{c}\text { set-11 } \\
\text { mai-12 }\end{array}$ & $\begin{array}{l}\text { Mogi das Cruzes } \\
\text { Mogi das Cruzes }\end{array}$ & $\begin{array}{l}\text { Não } \\
\text { Não }\end{array}$ & $\begin{array}{l}\text { Não } \\
\text { Não }\end{array}$ & $\begin{array}{l}\text { Não } \\
\text { Sim }\end{array}$ & $\begin{array}{l}\text { Não } \\
\text { Sim }\end{array}$ & $\begin{array}{l}\text { Não } \\
\text { Não }\end{array}$ & $\begin{array}{l}\text { Sim } \\
\text { Não }\end{array}$ & $\begin{array}{l}\text { Não } \\
\text { Sim }\end{array}$ & $\begin{array}{l}13250 \\
13250\end{array}$ & $\begin{array}{l}1997 \\
1997\end{array}$ & $\begin{array}{l}\text { Sim } \\
\text { Sim }\end{array}$ & $\begin{array}{l}\text { Não } \\
\text { Năo }\end{array}$ & & & & & & Sim & $\operatorname{sim}$ & & & Sim & $\operatorname{sim}$ & \\
\hline 493 & mar-08 & São Paulo & Sim & Sim & Nã̃o & $\begin{array}{l}\text { Samo } \\
\text { Não }\end{array}$ & $\begin{array}{l}\text { Nao } \\
\text { Não }\end{array}$ & Não & $\begin{array}{l}\text { Simm } \\
\text { Não }\end{array}$ & 46000 & 1979 & Sim & $\begin{array}{l}\text { Nao } \\
\text { Não }\end{array}$ & 4,3 & NaO & Nao & Sim & Sim & Sim & & Sim & Sim & Sim & & \\
\hline 494 & ago-08 & São Paulo & Não & Não & Sim & Sim & Não & Não & Não & 46000 & 1979 & Sim & Não & 4,3 & $\mathrm{Sim}$ & Não & Sim & Não & & & Sim & Não & & & \\
\hline 495 & jul-09 & São Paulo & Não & Não & sim & Sim & Não & Não & Não & 46000 & 1979 & Sim & Não & & Não & Não & sim & Não & & & Sim & Não & & & \\
\hline 496 & dez-10 & São Paulo & Não & Não & Não & Não & Não & Não & Sim & $\begin{array}{l}46000 \\
46000\end{array}$ & $\begin{array}{l}1979 \\
1979\end{array}$ & Sim & Não & & Não & Não & sim & Não & & & Sim & Não & & & \\
\hline 497 & abr-11 & $\begin{array}{l}\text { São Paulo } \\
\text { S̃̃ Paעo }\end{array}$ & Não & Não & Não & Não & Não & Não & Sim & 46000 & 1979 & Sim & Não & & Não & Não & Sim & Não & & & Sim & Não & & & \\
\hline 498 & out-11 & $\begin{array}{l}\text { Sao Paulo } \\
\text { São Paulo }\end{array}$ & Năo & Não & Não & Não & Não & Não & Sim & $\begin{array}{l}46000 \\
46000\end{array}$ & $\begin{array}{l}1979 \\
1979\end{array}$ & Sim & Não & & Não & Não & sim & Não & & & Sim & Não & & & \\
\hline 499 & abr-12 & $\begin{array}{l}\text { Sao Paúo } \\
\text { รão Paulo }\end{array}$ & Não & $\begin{array}{l}\text { Não } \\
\text { Não }\end{array}$ & $\begin{array}{l}\text { Nao } \\
\text { Não }\end{array}$ & Nao & Nao & Nao & Sim & 46000 & 1967 & Sim & Não & & Não & Não & Sim & Não & & & Sim & Não & & & \\
\hline 500 & $\begin{array}{r}\text { mai-i-00 } \\
\text { jul-03 }\end{array}$ & $\begin{array}{l}\text { Sao Paulo } \\
\text { São Paulo }\end{array}$ & $\begin{array}{l}\text { Não } \\
\text { Sim }\end{array}$ & $\begin{array}{l}\text { Não } \\
\text { Sim }\end{array}$ & $\begin{array}{l}\text { Não } \\
\text { Sim }\end{array}$ & $\begin{array}{l}\text { Não } \\
\text { SSim }\end{array}$ & $\begin{array}{l}\text { Não } \\
\text { Não }\end{array}$ & $\begin{array}{l}\text { Sim } \\
\text { Não }\end{array}$ & $\begin{array}{l}\text { Não } \\
\text { Não }\end{array}$ & 700 & 1967 & Sim & & & & & & & & & & & Sim & Sim & \\
\hline 501 & $\begin{array}{l}\text { Jul-03 } \\
\text { abr-05 }\end{array}$ & S̃̃o Paú & $\operatorname{sim}$ & 年 & $\operatorname{sim}$ & Sim & Nao & Nao & Não & 700 & 1967 & Sim & Não & 7,6 & Sim & Năo & Sim & Não & Sim & Não & Sim & Não & & & \\
\hline 502 & $\begin{array}{l}\text { abrobus } \\
\text { jun-05 }\end{array}$ & São Paulo & $\begin{array}{l}\text { Náo } \\
\text { Nazon }\end{array}$ & $\begin{array}{l}\text { Nào } \\
\text { âno }\end{array}$ & Não & Não & Sim & Sim & Não & 700 & 1967 & Sim & Não & & Sim & Nâo & & & Nâoo & Nâo & & & Sim & Sim & Sim \\
\hline 503 & 促 & São Paulo & Nấ & $\begin{array}{l}\text { Não } \\
\text { Nข๊o }\end{array}$ & $\begin{array}{l}\text { Năo } \\
\text { Nẫo }\end{array}$ & $\begin{array}{l}\text { Não } \\
\text { Não }\end{array}$ & Năo & Sim & Nào & 700 & $196 /$ & Sim & Năo & & Sim & Nào & & & Sim & Nào & & & Sim & Sim & Sim \\
\hline 505 & & $\begin{array}{l}\text { São Paulo } \\
\text { Sal }\end{array}$ & $\begin{array}{l}\text { Nao } \\
\text { Nãก }\end{array}$ & $\begin{array}{l}\text { Nao } \\
\text { Não }\end{array}$ & $\begin{array}{l}\text { Nao } \\
\text { Não }\end{array}$ & Nao & $\begin{array}{l}\text { Nao } \\
\text { Não }\end{array}$ & Sim & $\begin{array}{l}\text { Nao } \\
\text { Não }\end{array}$ & 700 & $\begin{array}{l}1967 \\
1967\end{array}$ & $\begin{array}{l}\text { Sim } \\
\text { Sim }\end{array}$ & $\begin{array}{l}\text { Nao } \\
\text { Nãก }\end{array}$ & & Sim & Nẫ & & & Nä & Nao & & & Sim & Sim & Sim \\
\hline 506 & set-05 & São Paulo & Não & $\begin{array}{l}\text { Nao } \\
\text { Não }\end{array}$ & $\begin{array}{l}\text { Nao } \\
\text { Năo }\end{array}$ & $\begin{array}{l}\text { Não } \\
\text { Não }\end{array}$ & $\begin{array}{l}\text { Nao } \\
\text { Não }\end{array}$ & $\mathrm{Sim}$ & $\begin{array}{l}\text { Nao } \\
\text { Nâo }\end{array}$ & 700 & 1967 & $\begin{array}{l}\text { sim } \\
\text { sim }\end{array}$ & $\begin{array}{l}\text { Nao } \\
\text { Nâo }\end{array}$ & & Sim & Năo & & & Não & Não & & & Sim & Sim & $\begin{array}{l}\text { Sim } \\
\text { sim }\end{array}$ \\
\hline 507 & out -05 & São Paulo & Não & $\begin{array}{l}\text { Não } \\
\text { Nã }\end{array}$ & Não & Não & Não & $\mathrm{Sim}$ & Não & 700 & 1967 & sim & & & Sim & Não & & & Sim & Sim & & & Sim & sim & $\begin{array}{l}\text { Sim } \\
\text { Sim }\end{array}$ \\
\hline 508 & nov- 05 & São Paulo & Não & Não & Não & Não & Não & $\mathrm{Sim}$ & Não & 700 & 1967 & Sim & Não & & Sim & Não & & & Nâo & Näo & & & sim & Sim & sim \\
\hline 509 & dez-05 & São Paulo & Não & Não & Não & Não & Não & Sim & Não & 700 & 1967 & Sim & Não & & Sim & Não & & & Não & Não & & & sim & Sim & Sim \\
\hline 510 & jan-06 & São Paulo & Não & Não & Não & Não & Não & Sim & Não & 700 & 1967 & Sim & Não & & Sim & Não & & & Não & Não & & & Sim & Sim & Sim \\
\hline 511 & fev-06 & São Paulo & Não & Não & Não & Não & Não & Sim & Não & 700 & 1967 & Sim & Não & & $\mathrm{Sim}$ & Não & & & Não & Não & & & Sim & Sim & Sim \\
\hline 512 & mai-06 & São Paulo & Não & Não & Não & Não & Não & Não & Sim & 700 & 1967 & Sim & Não & 7,6 & Sim & & Sim & Não & Não & Não & Sim & Não & & & \\
\hline 513 & fev-00 & Osasco & Não & Não & Sim & Sim & Não & Não & Não & 1050 & 1989 & Não & Sim & 1,0 & & & & & & & & & & & \\
\hline 514 & mar-00 & Osasco & Não & Não & Não & Não & Não & Sim & Não & 1050 & 1989 & Não & Sim & & & & & & Sim & Sim & & & Sim & Não & Sim \\
\hline 515 & ago-02 & Osasco & Não & Não & Não & Não & Não & Sim & Não & 1050 & 1989 & Não & Sim & & & & & & Sim & Sim & & & Sim & Não & Sim \\
\hline 516 & jun-03 & Osasco & Não & Não & Não & Não & Não & Sim & Não & 1050 & 1989 & Não & Sim & & & & & & Sim & Sim & & & Sim & Sim & Sim \\
\hline 517 & ago-03 & Osasco & Não & Não & Não & Não & Não & Sim & Não & 1050 & 1989 & Não & Sim & & Sim & & & & Não & Não & & & Sim & Sim & Sim \\
\hline 518 & set-03 & Osasco & Não & Não & Não & Não & Não & Sim & Não & 1050 & 1989 & Não & Sim & & Sim & & & & Não & Não & & & Sim & Sim & Sim \\
\hline 519 & nov-03 & Osasco & Não & Não & Sim & Sim & Não & Sim & Não & 1050 & 1989 & Não & sim & 1,0 & Sim & & Sim & Sim & Não & Não & Sim & Sim & Sim & Sim & Sim \\
\hline 520 & fev-04 & Osasco & Não & Não & Não & Não & Não & Sim & Não & 1050 & 1989 & Não & Sim & & Sim & & Sim & Sim & Não & Não & Sim & Sim & & & $\operatorname{Sim}$ \\
\hline 521 & abr-04 & Osasco & Não & Não & Não & Não & Não & Sim & Não & 1050 & $\begin{array}{l}1989 \\
1089\end{array}$ & Não & Sim & & Sim & & Sim & Sim & Não & Não & Sim & Sim & Sim & Sim & Sim \\
\hline 522 & mai-04 & Osasco & Não & Não & Não & Não & Não & Sim & Não & 1050 & 1989 & Não & Sim & & Sim & & Sim & Sim & Não & & Sim & Sim & Sim & Sim & im \\
\hline 523 & jun-04 & Osasco & Não & Não & Não & Não & Não & Sim & Não & 1050 & 198 & Nã & Sim & 1,0 & Sim & & Sim & $\mathrm{Si}$ & Não & & & si & $\mathrm{m}$ & m & im \\
\hline 524 & jul-04 & Osasco & Não & Não & Não & Não & Não & Sim & Não & 1050 & 198 & Não & Sim & & Sim & & Sim & Sir & Não & Nà & Sim & Sim & Sim & Sim & Sim \\
\hline 525 & \begin{tabular}{|l|} 
ago-04 \\
\end{tabular} & Osasco & Não & Não & Sim & Sim & Não & Não & Não & 1050 & 198 & Não & sim & 1,0 & $\mathrm{Sim}$ & & sim & Sim & Não & Não & Sim & sim & Sim & Sim & Sim \\
\hline 526 & mar-05 & Osasco & Não & Não & Não & Não & Não & Sim & Não & 1050 & 198 & Não & Sim & & Sim & & Sim & Sim & Não & & Sim & Sim & Sim & Sim & Sim \\
\hline 527 & abr-05 & Osasco & Não & Não & Não & Não & Não & Sim & Nã & 1050 & 19 & Nẫ & Sim & & Sim & & $\mathrm{Si}$ & & Não & & $\mathbf{s}$ & & Sim & $\mathrm{m}$ & Sim \\
\hline 528 & mai-05 & Osasco & Não & Não & Não & Não & Não & Sim & Não & & 19 & Não & Sim & & Sim & & sim & Sim & 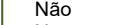 & & m & m & m & im & Sim \\
\hline 529 & $\begin{array}{c}\text { jun-05 } \\
\text { jum-105 }\end{array}$ & Osasco & Não & $\begin{array}{l}\text { Não } \\
\text { Nãon }\end{array}$ & $\begin{array}{l}\text { Não } \\
\text { Nân }\end{array}$ & Não & Não & Sim & Não & 1050 & 198 & Não & Sim & & Sim & & Sim & $\operatorname{sim}$ & Não & Não & Sim & Sim & Sim & Sim & Sim \\
\hline 530 & $\begin{array}{r}\text { jul-0.5 } \\
\text { aga } 0.05\end{array}$ & $\begin{array}{l}\text { Osassoo } \\
\text { Osasco }\end{array}$ & $\begin{array}{l}\text { Não } \\
\text { Nã̃ }\end{array}$ & $\begin{array}{l}\text { Não } \\
\text { Não }\end{array}$ & $\begin{array}{l}\text { Não } \\
\text { Năo }\end{array}$ & Não & $\begin{array}{l}\text { Não } \\
\text { Não }\end{array}$ & Sim & $\begin{array}{l}\text { Não } \\
\text { Não }\end{array}$ & $\begin{array}{l}1050 \\
1050\end{array}$ & $\begin{array}{l}198 \\
198\end{array}$ & $\begin{array}{l}\text { Não } \\
\text { Nẵo }\end{array}$ & Sim & & Sim & & Sim & Sim & $\begin{array}{l}\text { Não } \\
\text { Năno }\end{array}$ & $\begin{array}{l}\text { Não } \\
\text { Não }\end{array}$ & Sim & Sim & Sim & Sim & Sim \\
\hline $\begin{array}{lll}531 \\
532\end{array}$ & $\begin{array}{r}\text { ago-05 } \\
\text { set-05 }\end{array}$ & 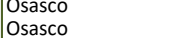 & $\begin{array}{l}\text { Noo } \\
\text { Não }\end{array}$ & $\begin{array}{l}\text { Não } \\
\text { Não }\end{array}$ & $\begin{array}{l}\begin{array}{l}\text { Nao } \\
\text { Não }\end{array} \\
\text { a }\end{array}$ & $\begin{array}{l}\text { Nao } \\
\text { Não }\end{array}$ & $\begin{array}{l}\text { Nao } \\
\text { Não }\end{array}$ & $\underset{\mathrm{Sim}}{\mathrm{Sim}}$ & 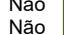 & & $\begin{array}{l}1989 \\
1989\end{array}$ & $\begin{array}{l}\text { Não } \\
\text { Não }\end{array}$ & $\underset{\mathrm{Sim}}{\mathrm{Sim}}$ & & $\begin{array}{l}\text { Sim } \\
\text { Sim }\end{array}$ & & sim & Sim & $\begin{array}{l}\text { Não } \\
\text { Não }\end{array}$ & $\begin{array}{l}\text { Nao } \\
\text { Não }\end{array}$ & Sim & Sim & $\begin{array}{l}\text { Sim } \\
\text { Sim }\end{array}$ & Sim & $\begin{array}{l}\text { Sim } \\
\text { Sim }\end{array}$ \\
\hline 533 & out-05 & $\begin{array}{l}\text { Osasco } \\
\text { Osasco }\end{array}$ & $\begin{array}{l}\text { Noo } \\
\text { Nãoo }\end{array}$ & $\begin{array}{l}\text { Nao } \\
\text { Não }\end{array}$ & $\begin{array}{l}\text { Nao } \\
\text { Năo }\end{array}$ & $\begin{array}{l}\text { Nao } \\
\text { Não }\end{array}$ & $\begin{array}{l}\text { Nao } \\
\text { Não }\end{array}$ & $\mathrm{Sim}$ & Não & 1050 & 1989 & $\begin{array}{l}\text { Nao } \\
\text { Não }\end{array}$ & $\begin{array}{l}\mathrm{Sim} \\
\mathrm{Sim}\end{array}$ & & $\mathrm{Sim}$ & & sim & $\mathrm{Sim}$ & Não & $\begin{array}{l}\text { Nao } \\
\text { Não }\end{array}$ & $\mathrm{Sim}$ & sim & sim & sim & $\mathrm{Sim}$ \\
\hline 534 & nov-05 & Osasco & Não & Não & Não & Não & Não & Sim & Não & 1050 & 1989 & Não & Sim & & $\mathrm{Sim}$ & & Sim & Sim & Não & Não & Sim & Sim & Sim & Sim & $\mathrm{Sim}$ \\
\hline 535 & dez -05 & Osasco & Não & Não & Não & Não & Não & Não & Sim & 1050 & 1989 & Não & Sim & & $\mathrm{Sim}$ & & Sim & Sim & Não & Não & Sim & Sim & Não & Não & Não \\
\hline 536 & fev-05 & São Paulo & Não & Não & Sim & Sim & Não & Não & Sim & 600 & 1975 & Sim & Não & 0,0 & & & & & & & & & & & \\
\hline 537 & jan-07 & São Paulo & Não & Não & Não & Não & Não & Não & Sim & 600 & 1975 & Sim & Não & 6,0 & Sim & & Sim & Sim & Não & Não & Sim & Sim & & & \\
\hline 538 & ago & São Paulo & Não & Não & Não & Não & Não & Sim & Nã & 60 & 1975 & Sim & Não & & Sim & & & & & & Sim & sim & Sim & Sim & Sim \\
\hline 539 & nov-07 & São Paulo & Não & Não & Não & Não & Não & Sim & Nã & 60 & 19 & Sim & Não & & Sim & & & & & & Sim & Sim & Sim & Sim & Sim \\
\hline 540 & jan-08 & Săo Paulo & Não & Não & Não & Não & Não & Sim & Não & 600 & 1975 & Sim & Não & & Sim & & & & & & Sim & Sim & Sim & Sim & Sim \\
\hline 541 & fev-08 & São Paulo & Não & Não & Não & Não & Não & Sim & Não & 600 & 1975 & Sim & Não & & Sim & & & & & & & & Sim & Sim & Sim \\
\hline 542 & $\begin{array}{c}m a r-08 \\
0\end{array}$ & $\begin{array}{l}\text { São Paulo } \\
\text { São Paulo }\end{array}$ & Não & Não & Não & Não & Não & Sim & $\begin{array}{l}\text { Não } \\
\text { Nân }\end{array}$ & 600 & $\begin{array}{l}1975 \\
1975\end{array}$ & Sim & $\begin{array}{l}\text { Não } \\
\text { Não }\end{array}$ & & Sim & & & & & & & & Sim & Sim & Sim \\
\hline 544 & $\begin{array}{l}\text { mai-08 } \\
\text { maico }\end{array}$ & $\begin{array}{l}\text { São Paulo } \\
\text { Sât }\end{array}$ & $\begin{array}{l}\text { Nao } \\
\text { Não }\end{array}$ & $\begin{array}{l}\text { Noo } \\
\text { Não }\end{array}$ & $\begin{array}{l}\text { Nao } \\
\text { Não }\end{array}$ & $\begin{array}{l}\text { Nao } \\
\text { Não }\end{array}$ & $\begin{array}{l}\text { Nao } \\
\text { Não }\end{array}$ & Sim & $\begin{array}{l}\text { Nao } \\
\text { Não }\end{array}$ & 600 & 1975 & Sim & $\begin{array}{l}\text { Nao } \\
\text { Não }\end{array}$ & & Sim & & & & & & $\operatorname{Sin}$ & Sim & $\begin{array}{l}\text { Sim } \\
\text { Sim }\end{array}$ & $\begin{array}{l}\text { Sim } \\
\text { Sim }\end{array}$ & Sim \\
\hline
\end{tabular}




\begin{tabular}{|c|c|c|c|c|c|c|c|c|c|c|c|c|c|c|c|c|c|c|c|c|c|c|c|c|c|}
\hline \multirow[b]{2}{*}{ ID } & \multirow[b]{2}{*}{$\begin{array}{r}\text { Data } \\
\text { Registro }\end{array}$} & \multirow{2}{*}{$\begin{array}{l}\text { IDENTIFICAÇÃO } \\
\text { Cidade }\end{array}$} & \multicolumn{7}{|c|}{ GERENC CONAMA / CETESB } & DADOS & OPOSTO & & exto geoló & gico & FASE I & APOR & FASE & ETIDA & $\mathrm{LN} /$ & & & solv & & & \\
\hline & & & AvP & IC & ID & Artx & PI & REM & ME & $\begin{array}{c}\text { Área } \\
\mathrm{m} 2\end{array}$ & $\begin{array}{l}\text { Data } \\
\text { instala }\end{array}$ & Sed. & $\begin{array}{c}\text { Rocha } \\
\text { alterada }\end{array}$ & $\begin{array}{l}\text { ZN Sat } \\
\text { (m) }\end{array}$ & $\begin{array}{c}\text { Detectado } \\
? ?\end{array}$ & $\begin{array}{c}\text { Delimitado } \\
?\end{array}$ & $\begin{array}{c}\text { Detectado } \\
?\end{array}$ & $\begin{array}{c}\text { Delimitado } \\
?\end{array}$ & $\mid \begin{array}{c}\text { Detectado } \\
?\end{array} ?$ & Delimit & $\begin{array}{c}\text { Detectado } \\
?\end{array}$ & $\begin{array}{c}\text { Delimitada } \\
?\end{array}$ & $\mid \begin{array}{c}\text { Remediação } \\
?\end{array}$ & $\begin{array}{c}\text { Remediação } \\
\text { Z Nsatu? }\end{array}$ & $\begin{array}{l}\text { Remediaçã } \\
\text { Z Sat? }\end{array}$ \\
\hline 545 & & São Paulo & Não & Não & Não & Não & Não & Sim & Não & 600 & 1975 & Sim & Não & & Sim & & & & & & & & Sim & Sim & Sim \\
\hline 546 & jul-08 & São Paulo & Não & Não & Não & Não & Não & Sim & Não & 600 & 1975 & Sim & Não & & Sim & & & & & & & & Sim & $\mathrm{Sim}$ & Sim \\
\hline 547 & ago-08 & São Paulo & Não & Não & Não & Nâo & Não & Sim & Nâo & 600 & 1975 & Sim & Não & & Sim & & & & & & & & Sim & Sim & Sim \\
\hline 548 & set-08 & São Paulo & Não & Não & Não & Não & Não & Sim & Não & 600 & 1975 & sim & Não & & sim & & & & & & & & sim & sim & Sim \\
\hline 549 & out -08 & São Paulo & Não & Não & Não & Não & Não & Sim & Não & 600 & 1975 & Sim & Não & & Sim & & & & & & & & sim & sim & sim \\
\hline 550 & nov-08 & São Paulo & Não & Não & Não & Não & Não & Sim & Não & 600 & 1975 & Sim & Não & & Sim & & & & & & & & Sim & Sim & Sim \\
\hline 551 & $\begin{array}{l}\text { dez-08 } \\
\text { jan-09 }-09\end{array}$ & $\begin{array}{l}\text { São Paullo } \\
\text { São Paulo }\end{array}$ & $\begin{array}{l}\text { Não } \\
\text { Não }\end{array}$ & $\begin{array}{l}\text { Não } \\
\text { Não }\end{array}$ & Não & Não & $\begin{array}{l}\text { Não } \\
\text { Não }\end{array}$ & $\begin{array}{l}\text { Sim } \\
\text { Sim }\end{array}$ & Não & 600 & $\begin{array}{l}1975 \\
1975\end{array}$ & $\begin{array}{l}\text { Sim } \\
\text { Sim }\end{array}$ & $\begin{array}{l}\text { Não } \\
\text { Não }\end{array}$ & & Sim & & & & & & & & Sim & Sim & sim \\
\hline $\begin{array}{l}552 \\
553\end{array}$ & $\begin{array}{l}\text { Jan-09 } \\
\text { fev-09 }\end{array}$ & $\begin{array}{l}\text { Sao Pauloo } \\
\text { São Paulo }\end{array}$ & $\begin{array}{l}\begin{array}{l}\text { Nâo } \\
\text { Nâo }\end{array} \\
\text { a }\end{array}$ & $\begin{array}{l}\text { Não } \\
\text { Não }\end{array}$ & $\begin{array}{l}\text { Não } \\
\text { Não }\end{array}$ & $\begin{array}{l}\text { Não } \\
\text { Não }\end{array}$ & $\begin{array}{l}\text { Não } \\
\text { Não }\end{array}$ & $\begin{array}{l}\text { Sim } \\
\text { Sim }\end{array}$ & $\begin{array}{l}\text { Não } \\
\text { Nẫo }\end{array}$ & $\begin{array}{l}600 \\
600\end{array}$ & $\begin{array}{l}1975 \\
1975\end{array}$ & $\begin{array}{l}\text { Sim } \\
\text { Sim }\end{array}$ & $\begin{array}{l}\text { Não } \\
\text { Não }\end{array}$ & & $\begin{array}{l}\text { Sim } \\
\text { Sim }\end{array}$ & & & & & & & & $\begin{array}{l}\text { Sim } \\
\text { Sim }\end{array}$ & $\begin{array}{l}\text { Sim } \\
\text { Sim }\end{array}$ & $\begin{array}{l}\text { Sim } \\
\text { Sim }\end{array}$ \\
\hline 554 & mar-09 & São Paulo & Não & Não & Não & Não & Não & Sim & Não & 600 & 1975 & Sim & Não & & Sim & & & & & & & & Sim & Sim & Sim \\
\hline 555 & abr-09 & São Paulo & Não & Não & Não & Não & Não & Sim & Não & 600 & 1975 & Sim & Não & & Sim & & & & & & & & Sim & Sim & Sim \\
\hline 556 & mai-09 & São Paulo & Não & Não & Não & Não & Não & Sim & Não & 600 & 1975 & Sim & Não & & Sim & & & & & & & & Sim & Sim & Sim \\
\hline 557 & $\begin{array}{l}\text { jun-09 } \\
\text { nut-09 }\end{array}$ & São Paulo & Não & Não & Não & Não & Não & Sim & Não & 600 & 1975 & Sim & Não & & Sim & & & & & & & & Sim & Sim & sim \\
\hline $\begin{array}{l}558 \\
559\end{array}$ & $\begin{array}{r}\text { out-099 } \\
\text { dez-09 }\end{array}$ & $\begin{array}{l}\text { São Paulo o } \\
\text { São Paulo }\end{array}$ & $\begin{array}{l}\text { Não } \\
\text { Não }\end{array}$ & $\begin{array}{l}\text { Não } \\
\text { Não }\end{array}$ & $\begin{array}{l}\text { Não } \\
\text { Não }\end{array}$ & $\begin{array}{l}\begin{array}{l}\text { Não } \\
\text { Não }\end{array} \\
\text { nate }\end{array}$ & $\begin{array}{l}\text { Não } \\
\text { Não }\end{array}$ & $\begin{array}{l}\text { Sim } \\
\text { Sim }\end{array}$ & $\begin{array}{l}\text { Não } \\
\text { Nâo }\end{array}$ & $\begin{array}{l}600 \\
600\end{array}$ & $\begin{array}{l}1975 \\
1975\end{array}$ & $\begin{array}{l}\text { Sim } \\
\text { Sim }\end{array}$ & $\begin{array}{l}\text { Não } \\
\text { Năo }\end{array}$ & & Sim & & & & & & & & Sim & Sim & sim \\
\hline 560 & jan-10 & $\begin{array}{l}\text { Sao Paulo } \\
\text { São Paulo }\end{array}$ & $\begin{array}{l}\text { Nä } \\
\text { Não }\end{array}$ & $\begin{array}{l}\text { Nao } \\
\text { Não }\end{array}$ & $\begin{array}{l}\text { Nao } \\
\text { Não }\end{array}$ & $\begin{array}{l}\text { Naò } \\
\text { Não }\end{array}$ & $\begin{array}{l}\text { Nao } \\
\text { Não }\end{array}$ & $\begin{array}{l}\text { Sim } \\
\text { Sim }\end{array}$ & $\begin{array}{l}\text { Nao } \\
\text { Não }\end{array}$ & 600 & $\begin{array}{l}1975 \\
1975\end{array}$ & sim & $\begin{array}{l}\text { Nao } \\
\text { Não }\end{array}$ & & $\begin{array}{l}\text { Sim } \\
\text { Sim }\end{array}$ & & & & & & & & $\begin{array}{l}\text { Sim } \\
\text { Sim }\end{array}$ & $\begin{array}{l}\text { Sim } \\
\text { Sim }\end{array}$ & $\begin{array}{l}\text { Sim } \\
\text { Sim }\end{array}$ \\
\hline 561 & mar-10 & São Paulo & Não & Não & Não & Não & Não & Sim & Não & 600 & 1975 & Sim & Não & & sim & & & & & & & & Sim & Sim & Sim \\
\hline 562 & jun-10 & São Paulo & Não & Não & Não & Não & Não & Sim & Não & 600 & 1975 & Sim & Não & & Sim & & & & & & & & Sim & Sim & sim \\
\hline 563 & jul-10 & São Paulo & Não & Não & Não & Não & Não & Sim & Não & 600 & 1975 & sim & Não & & Sim & & & & & & & & Sim & sim & Sim \\
\hline 564 & $\begin{array}{l}\text { ago-10 } \\
\text { set-10 }\end{array}$ & $\begin{array}{l}\text { São Paulo } \\
\text { São Paulo }\end{array}$ & Não & $\begin{array}{l}\text { Não } \\
\text { Não }\end{array}$ & Não & Não & $\begin{array}{l}\text { Não } \\
\text { Não }\end{array}$ & $\begin{array}{l}\text { Sim } \\
\text { Sim }\end{array}$ & $\begin{array}{l}\text { Não } \\
\text { Não }\end{array}$ & $\begin{array}{l}600 \\
600\end{array}$ & $\begin{array}{l}1975 \\
1975\end{array}$ & Sim & & & Sim & & & & & & & & Sim & Sim & sim \\
\hline $\begin{array}{l}565 \\
566\end{array}$ & $\begin{array}{l}\text { set-10 } \\
\text { jan-11 }\end{array}$ & $\begin{array}{l}\text { São Paulo } \\
\text { São Paulo }\end{array}$ & $\begin{array}{l}\text { Não } \\
\text { Nâno }\end{array}$ & $\begin{array}{l}\text { Não } \\
\text { Não }\end{array}$ & $\begin{array}{l}\text { Não } \\
\text { Não }\end{array}$ & $\begin{array}{l}\text { Não } \\
\text { Não }\end{array}$ & $\begin{array}{l}\text { Não } \\
\text { Não }\end{array}$ & $\begin{array}{l}\text { Sim } \\
\text { Sim }\end{array}$ & $\begin{array}{l}\text { Não } \\
\text { Não }\end{array}$ & $\begin{array}{l}600 \\
600\end{array}$ & $\begin{array}{l}1975 \\
1975\end{array}$ & $\begin{array}{l}\text { Sim } \\
\text { Sim }\end{array}$ & $\begin{array}{l}\text { Não } \\
\text { Nâo }\end{array}$ & & Sim & & & & & & & & Sim & Sim & Sim \\
\hline $\begin{array}{l}566 \\
567\end{array}$ & $\begin{array}{l}\text { lan-1 } \\
\text { fev-11 }\end{array}$ & $\begin{array}{l}\text { São Paulo } \\
\text { Sâlo }\end{array}$ & $\begin{array}{l}\text { Nao } \\
\text { Não }\end{array}$ & $\begin{array}{l}\text { Nao } \\
\text { Não }\end{array}$ & $\begin{array}{l}\text { Nao } \\
\text { Não }\end{array}$ & $\begin{array}{l}\text { Nao } \\
\text { Não }\end{array}$ & $\begin{array}{l}\text { Nao } \\
\text { Não }\end{array}$ & Sim & $\begin{array}{l}\text { Nao } \\
\text { Não }\end{array}$ & 600 & 1975 & Sim & $\begin{array}{l}\text { Nao } \\
\text { Não }\end{array}$ & & Sim & & & & & & & & $\begin{array}{l}\mathrm{Sim} \\
\mathrm{Sim}\end{array}$ & Sim & Sim \\
\hline 568 & mar-11 & $\begin{array}{l}\text { São Paulo } \\
\text { Sal }\end{array}$ & $\begin{array}{l}\text { Nao } \\
\text { Năo }\end{array}$ & Não & Não & Não & Não & Sim & Não & 600 & 1975 & sim & $\begin{array}{l}\text { Nao } \\
\text { Não }\end{array}$ & & sim & & & & & & & & sim & sim & sim \\
\hline 569 & abr-11 & São Paulo & Não & Não & Não & Não & Não & sim & Nõ & 600 & 1975 & sim & Não & & sim & & & & & & & & Sim & Sim & Sim \\
\hline $\begin{array}{l}570 \\
570\end{array}$ & mai-11 & São Paulo & Não & Não & Năo & Nă & Não & Sim & Não & 600 & 1975 & sim & Não & & sim & & & & & & & & Sim & sim & sim \\
\hline 571 & jun-11 & São Paulo & Não & Não & Não & Não & Não & $\mathrm{Sim}$ & Não & 600 & 1975 & Sim & Não & & Sim & & & & & & & & Sim & Sim & $\mathrm{Sim}$ \\
\hline 572 & dez-11 & São Paulo & Não & Não & Não & Não & Não & Sim & Não & 600 & 1975 & Sim & Não & & Sim & & & & & & & & Sim & Sim & Sim \\
\hline 573 & fev-12 & São Paulo & Não & Não & Não & Não & Não & Não & sim & 600 & 1975 & Sim & Não & & sim & & & & & & Sim & Sim & sim & sim & Sim \\
\hline 574 & set-06 & Campos de jordão & Sim & Sim & Não & Não & Não & Não & Não & 1000 & 1975 & Não & Sim & 2,0 & Sim & & Sim & Não & Sim & Não & Sim & Não & & & \\
\hline 575 & mar-07 & Campos de jordão & Não & Não & Sim & $\operatorname{sim}$ & Não & Não & Não & 1000 & 1975 & Não & Sim & 2,0 & $\operatorname{Sim}$ & & Sim & Sim & Sim & Sim & Sim & Sim & & & \\
\hline 576 & out-07 & Campos de jordão & Não & Não & Não & Não & Não & Sim & Não & 1000 & 1975 & Não & Sim & & & & & & & & Sim & Sim & Sim & Não & Sim \\
\hline 577 & $\begin{array}{c}n \text { nov-07 } \\
\text { jan-08 }\end{array}$ & \begin{tabular}{|l} 
Campos de jordão \\
Campos de jordão
\end{tabular} & Não & Não & Não & $\begin{array}{l}\text { Não } \\
\text { Não }\end{array}$ & Não & Sim & Não & $\begin{array}{l}1000 \\
1000\end{array}$ & $\begin{array}{l}1975 \\
1975\end{array}$ & Não & Sim & & & & & & & & Sim & Sim & Sim & Não & Sim \\
\hline $\begin{array}{l}578 \\
579\end{array}$ & $\begin{array}{l}\text { jan-08 } \\
\text { fev-08 }\end{array}$ & $\begin{array}{l}\text { Campos de jordado } \\
\text { Campos de jodazâ }\end{array}$ & $\begin{array}{l}\text { Não } \\
\text { Nẫo }\end{array}$ & $\begin{array}{l}\text { Não } \\
\text { Năo }\end{array}$ & $\begin{array}{l}\text { Não } \\
\text { Năo }\end{array}$ & $\begin{array}{l}\text { Não } \\
\text { Não }\end{array}$ & $\begin{array}{l}\text { Não } \\
\text { Não }\end{array}$ & Sim & $\begin{array}{l}\text { Não } \\
\text { Não }\end{array}$ & $\begin{array}{l}1000 \\
1000\end{array}$ & $\begin{array}{l}1975 \\
1975\end{array}$ & $\begin{array}{l}\text { Não } \\
\text { Não }\end{array}$ & $\underset{S i m}{S i m}$ & & & & & & & & & & Sim & Não & Sim \\
\hline $\begin{array}{l}5 / 9 \\
580\end{array}$ & mar-08 & $\begin{array}{l}\text { Campos d jordao } \\
\text { Campos de jordão }\end{array}$ & $\begin{array}{l}\text { Nao } \\
\text { Não }\end{array}$ & $\begin{array}{l}\text { Não } \\
\text { Não }\end{array}$ & $\begin{array}{l}\text { Năo } \\
\text { Năo }\end{array}$ & $\begin{array}{l}\text { Não } \\
\text { Não }\end{array}$ & $\begin{array}{l}\text { Não } \\
\text { Não }\end{array}$ & Sim & $\begin{array}{l}\text { Nao } \\
\text { Não }\end{array}$ & 1000 & 1975 & $\begin{array}{l}\text { Nao } \\
\text { Nãก }\end{array}$ & $\mathrm{Sim}$ & & & & & & & & & & & & Sim \\
\hline 581 & abr-08 & Campos de jordão & Não & Nä & Não & $\begin{array}{l}\text { Nao } \\
\text { Não }\end{array}$ & Não & Sim & Nao & 1000 & 1975 & $\begin{array}{l}\text { Nao } \\
\text { Não }\end{array}$ & $\mathrm{Sim}$ & & & & & & & & & & & & sim \\
\hline 582 & mai-08 & Campos de jordão & Não & Não & Não & Não & Não & $\mathrm{Sim}$ & Não & 1000 & 1975 & Nลว & $\mathrm{Sim}$ & & & & & & & & & & & & Sim \\
\hline 583 & jun-08 & Campos de jordão & Não & Não & Não & $\begin{array}{l}\text { Não } \\
\text { Não }\end{array}$ & Não & Sim & Não & 1000 & 1975 & Não & Sim & & & & & & & & & & & & sim \\
\hline 584 & jul-08 & Campos de jordão & Não & Não & Não & Não & Não & Sim & Não & 1000 & 1975 & Não & Sim & & & & & & & & & & & & Sim \\
\hline 585 & ago-08 & Campos de jordão & Não & Não & Não & Não & Não & Sim & Não & 1000 & 1975 & Não & $\mathrm{Sim}$ & & & & & & & & & & & & Sim \\
\hline 586 & set-08 & Campos de jordão & Não & Não & Não & Não & Não & Sim & Não & 1000 & 1975 & Não & $\mathrm{Sim}$ & & & & & & & & & & & & Sim \\
\hline 587 & out -08 & Campos de jordão & Não & Não & Não & Não & Não & Sim & Não & 1000 & 1975 & Não & Sim & & & & & & & & & & & & sim \\
\hline 588 & nov-08 & Campos de jordão & Não & Não & Não & Não & Não & sim & Não & 1000 & 1975 & Não & Sim & & & & & & & & & & & & Sim \\
\hline 589 & dez-08 & Campos de jordão & Não & Não & Não & Não & Não & Sim & Não & 1000 & 1975 & Não & Sim & & & & & & & & & & & & Sim \\
\hline 590 & $\begin{array}{l}\text { jan-09 } \\
\text { jan-10 }\end{array}$ & $\begin{array}{l}\text { Campos de jordão } \\
\text { Campos de jordão }\end{array}$ & Não & $\begin{array}{l}\text { Não } \\
\text { Não }\end{array}$ & Não & Não & Não & Sim & Não & $\begin{array}{l}1000 \\
1000\end{array}$ & $\begin{array}{l}1975 \\
1975\end{array}$ & $\begin{array}{l}\text { Não } \\
\text { Não }\end{array}$ & Sim & & & & & & & & & & & & $\operatorname{sim}$ \\
\hline $\begin{array}{l}591 \\
592\end{array}$ & $\begin{array}{l}\text { jan-10 } \\
\text { abr-10 }\end{array}$ & $\begin{array}{l}\text { Campos d jordao } \\
\text { Campos de jordâo }\end{array}$ & $\begin{array}{l}\text { Não } \\
\text { Não }\end{array}$ & $\begin{array}{l}\text { Não } \\
\text { Não }\end{array}$ & $\begin{array}{l}\text { Não } \\
\text { Não }\end{array}$ & $\begin{array}{l}\text { Não } \\
\text { Não }\end{array}$ & $\begin{array}{l}\text { Não } \\
\text { Não }\end{array}$ & $\begin{array}{l}\text { Sim } \\
\text { Sim }\end{array}$ & $\begin{array}{l}\text { Não } \\
\text { Não }\end{array}$ & $\begin{array}{l}1000 \\
1000\end{array}$ & $\begin{array}{l}1975 \\
1975\end{array}$ & $\begin{array}{l}\text { Não } \\
\text { Não }\end{array}$ & $\begin{array}{l}\text { Sim } \\
\text { Sim }\end{array}$ & & & & & & & & & & & & $\begin{array}{l}\text { Sim } \\
\text { Sim }\end{array}$ \\
\hline 593 & jun-10 & Campos de jordão & Não & Não & Não & $\begin{array}{l}\text { Não } \\
\text { Nã }\end{array}$ & Não & Sim & Não & 1000 & 1975 & Não & $\mathrm{Sim}$ & & & & & & & & & & & & sim \\
\hline 594 & jul-10 & Campos de jordão & Não & Não & Não & Não & Não & Sim & Não & 100 & 1975 & Não & Sim & & & & & & & & & & & & Sim \\
\hline 595 & set-10 & Campos de jordão & Nâo & Nă & Nâo & Não & Nâo & sim & Não & 1000 & 1975 & Nă & Sim & & & & & & & & & & & & Sim \\
\hline 596 & out-10 & Campos de jordão & Não & Não & Não & Não & Não & $\mathrm{Sim}$ & Não & 1000 & 1975 & Não & $\mathrm{Sim}$ & & & & & & & & & & & & sim \\
\hline 597 & jan-11 & Campos de jordão & Não & Não & Não & Não & Não & Sim & Não & 1000 & 1975 & Não & Sim & & & & & & & & & & & & Sim \\
\hline 598 & fev-11 & Campos de jordão & Não & Não & Não & Não & Não & Sim & Não & 100 & 1975 & Não & $\mathrm{Sim}$ & & & & & & & & & & & & Sim \\
\hline 599 & mar-11 & Campos de jordão & Não & Não & Não & Não & Não & Sim & Não & 100 & 1975 & Não & Sim & & & & & & & & Sim & Não & Sim & Não & Sim \\
\hline 600 & abr-11 & Campos de jordão & Não & Não & Não & Não & Não & Não & Sim & 1000 & 1975 & Não & Sim & & Sim & & & & & & Sim & Não & Não & Não & Não \\
\hline 601 & set-11 & Campos de jordão & Não & Não & Não & Não & Não & Não & Sim & 1000 & 1975 & Não & Sim & & Sim & & & & & & Sim & Não & Não & Não & Não \\
\hline 602 & mar-12 & \begin{tabular}{|l} 
Campos de jordão \\
Campos de jordão
\end{tabular} & Não & Não & Não & Não & Não & Não & Sim & 1000 & 1975 & Não & Sim & & Sim & & & & & & Sim & Não & Não & Não & Não \\
\hline $\begin{array}{l}603 \\
604\end{array}$ & $\begin{array}{r}\text { jan-13 } \\
\text { jun-06 }\end{array}$ & $\begin{array}{l}\text { Campos de jordão } \\
\text { Cottia }\end{array}$ & $\begin{array}{l}\text { Não } \\
\text { Sim }\end{array}$ & $\begin{array}{l}\text { Não } \\
\text { Sim }\end{array}$ & $\begin{array}{l}\text { Não } \\
\text { Não }\end{array}$ & $\begin{array}{l}\text { Não } \\
\text { Nẫ }\end{array}$ & $\begin{array}{l}\text { Não } \\
\text { Não }\end{array}$ & $\begin{array}{l}\text { Não } \\
\text { Năo }\end{array}$ & Sim & $\begin{array}{l}1000 \\
1600\end{array}$ & $\begin{array}{l}1975 \\
1991\end{array}$ & Não & Sim & 34 & $\operatorname{sim}$ & & Sim & & & & Sim & Não & Não & Não & Não \\
\hline $\begin{array}{l}004 \\
605\end{array}$ & $\begin{array}{l}\text { junn-06 } \\
\text { junn-07 }\end{array}$ & $\begin{array}{l}\text { Cotia } \\
\text { Cotia }\end{array}$ & Sim & $\begin{array}{l}\text { Sim } \\
\text { Não }\end{array}$ & $\begin{array}{l}\text { Não } \\
\text { Sim }\end{array}$ & Não & Não & $\begin{array}{l}\text { Não } \\
\text { Não }\end{array}$ & $\begin{array}{l}\text { Não } \\
\text { Não }\end{array}$ & $\begin{array}{l}1600 \\
1600\end{array}$ & 1991 & Não & Sim & $\begin{array}{l}3,4 \\
3,4\end{array}$ & Sim & Não & Sim & $\begin{array}{l}\text { Não } \\
\text { Sim }\end{array}$ & & & Sim & $\begin{array}{l}\text { Não } \\
\text { Simi }\end{array}$ & $\begin{array}{lll}\text { Nà } & \text { Nã } \\
\text { Nân }\end{array}$ & $\begin{array}{l}\text { Năo } \\
\text { Não }\end{array}$ & $\begin{array}{l}\text { Não } \\
\text { Não }\end{array}$ \\
\hline 6 & $\begin{array}{l}\text { set-07 } \\
\text { set }\end{array}$ & Cotia & $\begin{array}{l}\text { Nao } \\
\text { Não }\end{array}$ & Nao & Sãก & Nẵ & Não & $\begin{array}{l}\text { Nao } \\
\text { Sim }\end{array}$ & $\begin{array}{l}\text { Nao } \\
\text { Não }\end{array}$ & 1600 & 1991 & $\begin{array}{l}\text { Nao } \\
\text { Não }\end{array}$ & $\operatorname{sim}$ & $\begin{array}{l}, 4 \\
3,4\end{array}$ & Sim & Sim & 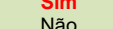 & Nãิ & & & Sim & Sim & $\begin{array}{l}\text { Nao } \\
\text { Sim }\end{array}$ & Não & $\begin{array}{l}\text { Năo } \\
\text { Sim }\end{array}$ \\
\hline 607 & $\begin{array}{l}\text { ent-07 } \\
\text { out }\end{array}$ & Cotia & Não & Nä & Não & Nลวิ & Nã & Sim & Nầ & 1600 & 1991 & Nล0 & Sim & $\begin{array}{l}3,4 \\
34\end{array}$ & Sim & Sim & $\begin{array}{l}\text { Nao } \\
\text { Não }\end{array}$ & $\begin{array}{l}\text { Nao } \\
\text { Não }\end{array}$ & & & sim & Sim & sim & $\begin{array}{l}\text { Nao } \\
\text { Não }\end{array}$ & Sim \\
\hline 608 & nov-07 & Cotia & Não & Não & Não & Não & Sim & Sim & Não & 1600 & 1991 & Não & $\mathrm{Sim}$ & 3.4 & sim & Sim & Não & Não & & & sim & sim & sim & Não & $\mathrm{Sim}$ \\
\hline 609 & nov-07 & Cotia & Não & Não & Não & Não & Não & Sim & Não & 1600 & 1991 & Não & Sim & 3,4 & Sim & Sim & Não & Não & & & Sim & Sim & Sim & Não & Sim \\
\hline 610 & dez-07 & Cotia & Não & Não & Não & Não & Não & Sim & Não & 1600 & 1991 & Não & Sim & 3,4 & Sim & Sim & Não & Não & & & Sim & sim & sim & Não & $\mathrm{Sim}$ \\
\hline 611 & jan-08 & Cotia & Não & Não & Não & Não & Não & Sim & Não & 1600 & 1991 & Não & $\mathrm{Sim}$ & 3,4 & Sim & Sim & Não & Não & & & sim & sim & Sim & Não & Sim \\
\hline 612 & fev-08 & Cotia & Não & Não & Não & Não & Não & Sim & Não & 1600 & 1991 & Não & Sim & 3,4 & Sim & Sim & Não & Não & & & Sim & Sim & Sim & Não & Sim \\
\hline
\end{tabular}




\begin{tabular}{|c|c|c|c|c|c|c|c|c|c|c|c|c|c|c|c|c|c|c|c|c|c|c|c|c|c|}
\hline \multirow[b]{2}{*}{ ID } & \multirow[b]{2}{*}{$\begin{array}{c}\text { Data } \\
\text { Registro }\end{array}$} & \multirow{2}{*}{$\begin{array}{l}\text { IDENTIFICAÇĀ̃o } \\
\text { Cidade }\end{array}$} & \multicolumn{7}{|c|}{ GERENC CONAMA / CETESB } & \multicolumn{2}{|c|}{ DADOS DO POSTO } & & exto geoló & & FASE & APOR & FASE & RETIDA & LN/ & APL & Dis & solv & & & \\
\hline & & & AvP & IC & ID & Artx & PI & REM & ME & $\begin{array}{c}\text { Área } \\
\text { m2 }\end{array}$ & $\begin{array}{l}\text { Data } \\
\text { instala }\end{array}$ & Sed. & \begin{tabular}{|c|} 
Rocha \\
alterada
\end{tabular} & $\begin{array}{c}\text { ZN Sat } \\
(\mathrm{m})\end{array}$ & $\begin{array}{c}\text { Detectado } \\
? ?\end{array}$ & $\begin{array}{c}\text { Delimitado } \\
?\end{array}$ & $\begin{array}{c}\text { Detectado } \\
?\end{array}$ & $\begin{array}{c}\text { Delimitado } \\
?\end{array}$ & $\mid \begin{array}{c}\text { Detectado } \\
?\end{array} ?$ & Delimit & $\begin{array}{c}\text { Detectado } \\
\text { ? }\end{array}$ & $\begin{array}{c}\text { Delimitada } \\
?\end{array}$ & $\begin{array}{c}\text { Remediação } \\
\text { ? }\end{array}$ & $\begin{array}{c}\text { Remediação } \\
\text { Z Nsatu? }\end{array} \mid$ & $\begin{array}{c}\text { Remediacãa } \\
\text { Z Sat? }\end{array}$ \\
\hline 613 & mar-08 & Cotia & Não & Não & Não & Não & Não & Sim & Não & 1600 & 1991 & Não & Sim & 3,4 & Sim & Sim & Não & Não & & & Sim & Sim & Sim & Não & Sim \\
\hline $\begin{array}{l}614 \\
615\end{array}$ & $\begin{array}{r}\text { abr-08 } \\
\text { mai-08 }\end{array}$ & $\begin{array}{l}\text { Cotia } \\
\text { Cotia }\end{array}$ & $\begin{array}{l}\text { Não } \\
\text { Não }\end{array}$ & $\begin{array}{l}\text { Não } \\
\text { Não }\end{array}$ & $\begin{array}{l}\text { Não } \\
\text { Não }\end{array}$ & $\begin{array}{l}\text { Não } \\
\text { Não }\end{array}$ & $\begin{array}{l}\text { Não } \\
\text { Nã̃o }\end{array}$ & Sim & $\begin{array}{l}\text { Não } \\
\text { Não }\end{array}$ & $\begin{array}{l}1600 \\
1600\end{array}$ & $\begin{array}{l}1991 \\
1991\end{array}$ & $\begin{array}{l}\text { Não } \\
\text { Não }\end{array}$ & Sim & 3,4 & Sim & Sim & Não & Não & & & Sim & Sim & Sim & Não & Sim \\
\hline $\begin{array}{l}615 \\
616\end{array}$ & jun-08 & Cotia & $\begin{array}{l}\text { Não } \\
\text { Nâo }\end{array}$ & $\begin{array}{l}\text { Nao } \\
\text { Nâo }\end{array}$ & $\begin{array}{l}\text { Nao } \\
\text { Não }\end{array}$ & $\begin{array}{l}\text { Nao } \\
\text { Não }\end{array}$ & $\begin{array}{l}\text { Nao } \\
\text { Não }\end{array}$ & Sim & $\begin{array}{l}\text { Nao } \\
\text { Não }\end{array}$ & 1600 & 1991 & $\begin{array}{l}\text { Noo } \\
\text { Não }\end{array}$ & $\begin{array}{l}\text { Sim } \\
\text { Sim }\end{array}$ & $\begin{array}{l}3,4 \\
3,4\end{array}$ & $\operatorname{Sim}_{\text {Sim }}$ & $\underset{S i m}{S i m}$ & $\begin{array}{l}\text { Nao } \\
\text { Não }\end{array}$ & $\begin{array}{l}\text { Não } \\
\text { Não }\end{array}$ & & & Sim & $\begin{array}{l}\text { Sim } \\
\text { Sim }\end{array}$ & Sim & $\begin{array}{l}\text { Não } \\
\text { Não }\end{array}$ & $\operatorname{Sim}_{\text {Sim }}$ \\
\hline 617 & jul-08 & Cotia & Não & Não & Não & Não & Não & Sim & Não & 1600 & 1991 & Não & $\mathrm{Sim}$ & 3,4 & Sim & $\mathrm{Sim}$ & Não & Não & & & Sim & sim & Sim & Não & Sim \\
\hline 618 & ago-08 & Cotia & Não & Não & Não & Não & Não & Sim & Não & 1600 & 1991 & Não & Sim & 3,4 & Sim & Sim & Não & Não & & & Sim & Sim & Sim & Não & Sim \\
\hline 619 & $\begin{array}{r}\text { set-08 } \\
\text { set-08 }\end{array}$ & $\begin{array}{l}\text { Cotia } \\
\text { Cotia }\end{array}$ & Não & Não & Não & Não & Não & sim & Não & 1600 & 1991 & Não & Sim & 3,4 & Sim & Sim & Não & Não & & & Sim & Sim & Sim & Não & Sim \\
\hline 620 & $\begin{array}{l}\text { out-08 } \\
\text { nov-08 }\end{array}$ & $\begin{array}{l}\text { Cotia } \\
\text { Cotia }\end{array}$ & Não & Não & Não & Não & Não & Sim & Não & $\begin{array}{l}1600 \\
1600\end{array}$ & 1991 & Não & Sim & 3,4 & Sim & Sim & Não & Não & & & Sim & Sim & & Não & Sim \\
\hline $\begin{array}{l}621 \\
622\end{array}$ & $\begin{array}{l}\text { nov-08 } \\
\text { dez-08 }\end{array}$ & 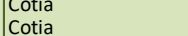 & $\begin{array}{l}\text { Não } \\
\text { Não }\end{array}$ & $\begin{array}{l}\text { Não } \\
\text { Não }\end{array}$ & $\begin{array}{l}\text { Não } \\
\text { Não }\end{array}$ & $\begin{array}{l}\text { Não } \\
\text { Não }\end{array}$ & $\begin{array}{l}\text { Não } \\
\text { Não }\end{array}$ & $\begin{array}{l}\text { Sim } \\
\text { Sim }\end{array}$ & $\begin{array}{l}\text { Não } \\
\text { Não }\end{array}$ & $\begin{array}{l}1600 \\
1600\end{array}$ & $\begin{array}{l}1991 \\
1991\end{array}$ & $\begin{array}{l}\text { Não } \\
\text { Não }\end{array}$ & Sim & $\begin{array}{l}3,4 \\
3,4\end{array}$ & Sim & Sim & $\begin{array}{l}\text { Não } \\
\text { Não }\end{array}$ & $\begin{array}{l}\text { Não } \\
\text { Não }\end{array}$ & & & Sim & $\begin{array}{l}\text { Sim } \\
\text { Sim }\end{array}$ & $\begin{array}{l}\text { Sim } \\
\text { Sim }\end{array}$ & $\begin{array}{l}\text { Não } \\
\text { Não }\end{array}$ & Sim \\
\hline $\begin{array}{l}623 \\
623\end{array}$ & jan-09 & Cotia & $\begin{array}{l}\text { Nao } \\
\text { Não }\end{array}$ & $\begin{array}{l}\text { Nao } \\
\text { Não }\end{array}$ & $\begin{array}{l}\text { Nao } \\
\text { Não }\end{array}$ & $\begin{array}{l}\text { Nao } \\
\text { Não }\end{array}$ & $\begin{array}{l}\text { Nao } \\
\text { Não }\end{array}$ & Sim & $\begin{array}{l}\text { Nao } \\
\text { Não }\end{array}$ & 1600 & $\begin{array}{l}1991 \\
1991\end{array}$ & $\begin{array}{l}\text { Noo } \\
\text { Não }\end{array}$ & Sim & $\begin{array}{l}3,4 \\
3,4\end{array}$ & Sim & $\mathrm{Sim}$ & $\begin{array}{l}\text { Nao } \\
\text { Não }\end{array}$ & $\begin{array}{l}\text { Nao } \\
\text { Não }\end{array}$ & & & Sim & Sim & Sim & $\begin{array}{l}\text { Nao } \\
\text { Não }\end{array}$ & Sim \\
\hline 624 & fev-09 & Cotia & Não & Não & Não & Não & Não & Sim & Não & 1600 & 1991 & Não & Sim & 3,4 & Sim & Sim & Não & Não & & & sim & sim & sim & Não & sim \\
\hline 625 & mar-09 & $\begin{array}{l}\text { Cotia } \\
\text { Cotia }\end{array}$ & Não & Não & Não & Não & Não & sim & Não & 1600 & 1991 & Não & Sim & 3,4 & Sim & Sim & Não & Não & & & Sim & Sim & Sim & Não & Sim \\
\hline 626 & abr-09 & $\begin{array}{l}\text { Cotia } \\
\end{array}$ & Não & Não & Não & Não & Não & sim & Não & $\begin{array}{l}1600 \\
1600\end{array}$ & 1991 & Não & Sim & 3,4 & Sim & Sim & Não & Não & & & Sim & Sim & Sim & Não & Sim \\
\hline $\begin{array}{l}627 \\
628\end{array}$ & 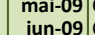 & $\begin{array}{l}\text { Cotia } \\
\text { Cotia }\end{array}$ & $\begin{array}{l}\text { Não } \\
\text { Não }\end{array}$ & $\begin{array}{l}\text { Não } \\
\text { Não }\end{array}$ & $\begin{array}{l}\text { Não } \\
\text { Năo }\end{array}$ & $\begin{array}{l}\text { Não } \\
\text { Não }\end{array}$ & Não & Sim & $\begin{array}{l}\text { Não } \\
\text { Não }\end{array}$ & $\begin{array}{l}1600 \\
1600\end{array}$ & $\begin{array}{l}1991 \\
1991\end{array}$ & Não & Sim & $\begin{array}{l}3,4 \\
3,4\end{array}$ & Sim & Sim & $\begin{array}{l}\text { Não } \\
\text { Não }\end{array}$ & $\begin{array}{l}\text { Não } \\
\text { Não }\end{array}$ & & & Sim & Sim & Sim & Não & Sim \\
\hline $\begin{array}{l}628 \\
629\end{array}$ & $\begin{array}{l}\text { oul-09 } \\
\text { jul }\end{array}$ & 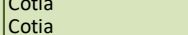 & $\begin{array}{l}\text { Não } \\
\text { Não }\end{array}$ & 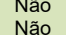 & $\begin{array}{l}\text { Năo } \\
\text { Não }\end{array}$ & $\begin{array}{l}\text { Não } \\
\text { Não }\end{array}$ & $\begin{array}{l}\text { Não } \\
\text { Não }\end{array}$ & $\begin{array}{l}\text { Sim } \\
\text { Sim }\end{array}$ & $\begin{array}{l}\text { Não } \\
\text { Não }\end{array}$ & $\begin{array}{l}1600 \\
1600\end{array}$ & $\begin{array}{l}1991 \\
1991\end{array}$ & $\begin{array}{l}\text { Não } \\
\text { Não }\end{array}$ & $\begin{array}{l}\text { Sim } \\
\text { Sim }\end{array}$ & $\begin{array}{l}3,4 \\
3,4\end{array}$ & $\begin{array}{l}\text { Sim } \\
\text { Sim }\end{array}$ & $\begin{array}{l}\text { Sim } \\
\text { Sim }\end{array}$ & $\begin{array}{l}\text { Não } \\
\text { Não }\end{array}$ & $\begin{array}{l}\text { Não } \\
\text { Não }\end{array}$ & & & $\begin{array}{l}\text { Sim } \\
\text { Sim }\end{array}$ & Sim & $\begin{array}{l}\text { Sim } \\
\text { sim }\end{array}$ & $\begin{array}{l}\text { Não } \\
\text { Não }\end{array}$ & Sim \\
\hline 630 & out-09 & Cotia & Não & Não & Não & Não & Não & Nẫo & Sim & 1600 & 1991 & Não & $\mathrm{Sim}$ & & Não & Não & Não & Não & & & Sim & Sim & $\operatorname{sim}$ & Nao & \\
\hline 631 & set-10 & Cotia & Não & Não & Não & Não & Não & Não & Sim & 1600 & 1991 & Não & Sim & & Não & Não & Não & Não & & & Sim & Sim & & & \\
\hline 632 & mar-11 & Cotia & Não & Não & Não & Não & Não & Não & Sim & 1600 & 1991 & Não & Sim & & Não & Não & Não & Não & & & Sim & Sim & & & \\
\hline $\begin{array}{l}633 \\
634\end{array}$ & $\begin{array}{r}\text { set-11 } \\
\text { mar-12 }\end{array}$ & $\begin{array}{l}\text { Cotia } \\
\text { Cotia }\end{array}$ & $\begin{array}{l}\text { Não } \\
\text { Não }\end{array}$ & $\begin{array}{l}\text { Não } \\
\text { Não }\end{array}$ & $\begin{array}{l}\text { Não } \\
\text { Não }\end{array}$ & $\begin{array}{l}\text { Não } \\
\text { Não }\end{array}$ & $\begin{array}{l}\text { Não } \\
\text { Não }\end{array}$ & $\begin{array}{l}\text { Não } \\
\text { Não }\end{array}$ & Sim & $\begin{array}{l}1600 \\
1600\end{array}$ & $\begin{array}{l}1991 \\
1991\end{array}$ & $\begin{array}{l}\text { Não } \\
\text { Nã }\end{array}$ & Sim & & $\begin{array}{l}\text { Não } \\
\text { Não }\end{array}$ & $\begin{array}{l}\text { Não } \\
\text { Não }\end{array}$ & $\begin{array}{l}\text { Não } \\
\text { Não }\end{array}$ & $\begin{array}{l}\text { Não } \\
\text { Não }\end{array}$ & & & Sim & Sim & & & \\
\hline $\begin{array}{l}6345 \\
635\end{array}$ & $\mid \begin{array}{r}\text { mar-12 } \\
\text { jan-04 }\end{array}$ & $\begin{array}{l}\text { Cotáa } \\
\text { São Paulo }\end{array}$ & $\begin{array}{l}\text { Não } \\
\text { Saim }\end{array}$ & $\begin{array}{l}\text { Năo } \\
\text { Sim }\end{array}$ & $\begin{array}{l}\text { Năo } \\
\text { Não }\end{array}$ & $\begin{array}{l}\text { Não } \\
\text { Não }\end{array}$ & $\begin{array}{l}\text { Não } \\
\text { Não }\end{array}$ & $\begin{array}{l}\text { Não } \\
\text { Não }\end{array}$ & $\begin{array}{l}\text { Sim } \\
\text { Não }\end{array}$ & $\begin{array}{l}1600 \\
1750\end{array}$ & $\begin{array}{l}1991 \\
1997\end{array}$ & $\begin{array}{l}\text { Não } \\
\text { Sim }\end{array}$ & $\begin{array}{l}\text { Sim } \\
\text { Não }\end{array}$ & 2,3 & $\begin{array}{l}\text { Não } \\
\text { Sim }\end{array}$ & $\begin{array}{l}\text { Não } \\
\text { Não }\end{array}$ & $\begin{array}{l}\text { Não } \\
\text { Sim }\end{array}$ & $\begin{array}{l}\text { Não } \\
\text { Não }\end{array}$ & & & $\begin{array}{l}\text { Sim } \\
\text { Sim }\end{array}$ & $\begin{array}{l}\text { Sim } \\
\text { Sim }\end{array}$ & & & \\
\hline 636 & fev-04 & São Paulo & Não & Não & Sim & Sim & Não & Não & Não & 1750 & 1997 & Sim & $\begin{array}{l}\text { Não } \\
\text { Nân }\end{array}$ & 2,3 & $\mathrm{Sim}$ & $\begin{array}{l}\text { Nao } \\
\text { Sim }\end{array}$ & Não & Não & $\mathrm{Sim}$ & Sim & Sim & Sim & & & \\
\hline 637 & fev-04 & São Paulo & Não & Não & Não & Não & Sim & Sim & Não & 1750 & 1997 & Sim & Não & 2,7 & Sim & Sim & Não & Não & Sim & Sim & Sim & Sim & Sim & Sim & Sim \\
\hline 638 & mar-04 & São Paulo & Não & Não & Não & Não & Não & Sim & Não & $\begin{array}{l}1750 \\
1750\end{array}$ & $\begin{array}{l}1997 \\
\end{array}$ & Sim & Não & 2,7 & Sim & Sim & Não & Não & Sim & Sim & & & Sim & Sim & \\
\hline 639 & abr-04 & São Paulo & Não & Não & Não & $\begin{array}{l}\text { Não } \\
\text { N20ี }\end{array}$ & Não & Sim & Não & $\begin{array}{l}1750 \\
1750\end{array}$ & $\begin{array}{l}1997 \\
1997\end{array}$ & Sim & Não & $\begin{array}{l}2,7 \\
3,3\end{array}$ & Sim & Sim & & & Sim & Sim & & & Sim & Sim & \\
\hline $\begin{array}{l}640 \\
641\end{array}$ & 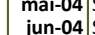 & $\begin{array}{l}\text { Sao Paulo } \\
\text { São Pulo }\end{array}$ & $\begin{array}{l}\text { Não } \\
\text { Nẵo }\end{array}$ & $\begin{array}{l}\text { Não } \\
\text { Não }\end{array}$ & $\begin{array}{l}\text { Năo } \\
\text { Năo }\end{array}$ & $\begin{array}{l}\text { Não } \\
\text { Não }\end{array}$ & $\begin{array}{l}\text { Não } \\
\text { Não }\end{array}$ & $\begin{array}{l}\text { Sim } \\
\text { Sim }\end{array}$ & $\begin{array}{l}\text { Não } \\
\text { Não }\end{array}$ & $\begin{array}{l}1750 \\
1750\end{array}$ & $\begin{array}{l}1997 \\
1997\end{array}$ & Sim & $\begin{array}{l}\text { Não } \\
\text { Năo }\end{array}$ & 3,3 & Sim & Sim & & & Sim & Sim & & & Sim & Sim & \\
\hline $\begin{array}{l}641 \\
642\end{array}$ & $\begin{array}{r}\text { jul-04 } \\
\text { jul }\end{array}$ & $\begin{array}{l}\text { Sao Paulo } \\
\text { São Paulo }\end{array}$ & $\begin{array}{l}\text { Nao } \\
\text { Não }\end{array}$ & $\begin{array}{l}\text { Nao } \\
\text { Nâo }\end{array}$ & $\begin{array}{l}\text { Năo } \\
\text { Não }\end{array}$ & $\begin{array}{l}\text { Năo } \\
\text { Não }\end{array}$ & $\begin{array}{l}\text { Não } \\
\text { Nâo }\end{array}$ & $\begin{array}{l}\text { Sim } \\
\text { Sim }\end{array}$ & $\begin{array}{l}\text { Nao } \\
\text { Não }\end{array}$ & $\begin{array}{l}1750 \\
1750\end{array}$ & 1997 & Sim & $\begin{array}{l}\text { Nâo } \\
\text { Não }\end{array}$ & & $\begin{array}{l}\text { Sim } \\
\text { Sim }\end{array}$ & $\begin{array}{l}\text { Sim } \\
\text { Sim }\end{array}$ & & & Sim & sim & & & Sim & Sim & \\
\hline 643 & ago-04 & São Paulo & Não & Não & Não & Não & Não & Sim & Não & 1750 & 1997 & Sim & Não & & Sim & Sim & & & Sim & Sim & & & Sim & Sim & \\
\hline 644 & set-04 & São Paulo & Não & Não & Não & Não & Não & Sim & Não & 1750 & 1997 & Sim & Não & 2,7 & Sim & Sim & & & Sim & Sim & & & Sim & Sim & \\
\hline 645 & out-04 & São Paulo & Não & Não & Não & Não & Não & sim & Não & 1750 & 1997 & Sim & Não & & Sim & Sim & & & & $\mathbf{s i}$ & & & Sim & $\operatorname{sim}$ & \\
\hline 646 & nov-04 & São Paulo & Não & Não & Não & Não & Não & Sim & Não & 1750 & 1997 & Sim & Não & & Sim & Sim & & & Sim & $\mathbf{S i}$ & & & Sim & Sim & \\
\hline 647 & dez-04 & São Paulo & Não & Não & Não & Não & Não & $\operatorname{sim}$ & Não & 1750 & 1997 & Sim & Não & & Sim & Sim & & & Sim & Sim & & & Sim & Sim & \\
\hline 648 & jan-05 & São Paulo & Não & Não & Não & Não & Não & Sim & Não & 1750 & 1997 & Sim & Não & & Sim & Sim & & & Sim & Sim & & & Sim & Sim & \\
\hline 649 & fev-05 & São Paulo & Não & Não & Não & Não & Não & Sim & Não & 1750 & 1997 & Sim & Não & & Sim & Sim & & & Sim & Sim & & & Sim & Sim & \\
\hline 650 & mar-05 & São Paulo & Não & Não & Não & Não & Não & Sim & Não & 1750 & 1997 & Sim & Não & & Sim & Sim & & & Sim & Sim & & & Sim & Sim & \\
\hline 651 & abr-05 & São Paulo & Não & Não & Não & Não & Não & Sim & Não & $\begin{array}{l}1750 \\
1750\end{array}$ & $\begin{array}{l}1997 \\
\end{array}$ & Sim & Não & & Sim & Sim & & & Sim & m & & & Sim & Sim & \\
\hline 652 & mai-05 & São Paulo & Não & Não & $\begin{array}{l}\text { Não } \\
\text { Não }\end{array}$ & $\begin{array}{l}\text { Não } \\
\text { N20̃ }\end{array}$ & Não & sim & Não & $\begin{array}{l}1750 \\
1750\end{array}$ & $\begin{array}{l}1997 \\
1197\end{array}$ & Sim & Não & & sim & Sim & & & Sim & m & & & Sim & Sim & \\
\hline $\begin{array}{l}653 \\
654 \\
654\end{array}$ & $\begin{array}{l}\text { jun-05 } \\
\text { jul-05 }\end{array}$ & $\begin{array}{l}\text { Sao Paulo } \\
\text { São Palo }\end{array}$ & $\begin{array}{l}\text { Não } \\
\text { Nẵo }\end{array}$ & $\begin{array}{l}\text { Não } \\
\text { Não }\end{array}$ & $\begin{array}{l}\text { Não } \\
\text { Não }\end{array}$ & $\begin{array}{l}\text { Não } \\
\text { Não }\end{array}$ & $\begin{array}{l}\text { Não } \\
\text { Não }\end{array}$ & Sim & $\begin{array}{l}\text { Não } \\
\text { Não }\end{array}$ & $\begin{array}{l}1750 \\
1750\end{array}$ & $\begin{array}{l}1997 \\
1997\end{array}$ & Sim & $\begin{array}{l}\text { Não } \\
\text { Năno }\end{array}$ & & Sim & Sim & & & Sim & Sim & & & Sim & Sim & \\
\hline $\begin{array}{l}654 \\
655\end{array}$ & $\begin{array}{r}\text { Jul-05 } \\
\text { ago-05 }\end{array}$ & $\begin{array}{l}\text { sao Paulo } \\
\text { São Paulo }\end{array}$ & $\begin{array}{l}\text { Não } \\
\text { Não }\end{array}$ & $\begin{array}{l}\text { Nao } \\
\text { Não }\end{array}$ & $\begin{array}{l}\text { Não } \\
\text { Não }\end{array}$ & $\begin{array}{l}\text { Năo } \\
\text { Não }\end{array}$ & $\begin{array}{l}\text { Nao } \\
\text { Não }\end{array}$ & $\begin{array}{l}\text { Sim } \\
\text { Sim }\end{array}$ & $\begin{array}{l}\text { Nao } \\
\text { Não }\end{array}$ & $\begin{array}{l}1750 \\
1750\end{array}$ & $\begin{array}{l}1997 / \\
1997\end{array}$ & 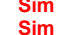 & $\begin{array}{l}\text { Nao } \\
\text { Não }\end{array}$ & & $\begin{array}{l}\text { Sim } \\
\text { Sim }\end{array}$ & Sim & & & $\begin{array}{l}\text { Sim } \\
\text { sim }\end{array}$ & $\begin{array}{l}\text { Sim } \\
\text { sim }\end{array}$ & & & $\begin{array}{l}\text { Sim } \\
\text { Sim }\end{array}$ & Sim & \\
\hline 要 656 & set-05 & $\begin{array}{l}\text { São Paulo } \\
\text { Sal }\end{array}$ & Não & Não & $\begin{array}{l}\text { Nao } \\
\text { Não }\end{array}$ & $\begin{array}{l}\text { Nao } \\
\text { Não }\end{array}$ & $\begin{array}{l}\text { Nao } \\
\text { Não }\end{array}$ & $\begin{array}{l}\mathrm{Sim} \\
\mathrm{Sim}\end{array}$ & $\begin{array}{l}\text { Nao } \\
\text { Não }\end{array}$ & 1750 & 1997 & Sim & $\begin{array}{l}\text { Nao } \\
\text { Não }\end{array}$ & & $\begin{array}{l}\mathrm{Sim} \\
\mathrm{Sim}\end{array}$ & Sim & & & $\mathrm{Sim}$ & Sim & & & Sim & Sim & \\
\hline 657 & \begin{tabular}{l|l} 
out-05 \\
\end{tabular} & São Paulo & Não & Não & Não & Não & Não & Sim & Não & 1750 & 1997 & Sim & Não & & Sim & Sim & & & Sim & Sim & & & Sim & Sim & \\
\hline 658 & nov-05: & São Paulo & Não & Não & Não & Não & Não & sim & Não & 1750 & 1997 & Sim & Não & & Sim & sim & & & Sim & & & & sim & Sim & \\
\hline 659 & dez-05 & São Paulo & Não & Não & Não & Não & Não & Sim & $\mathrm{N}$ & 175 & 1997 & Sim & Não & 2,8 & Sim & sim & & & 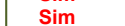 & & & & & sim & \\
\hline 660 & jan-06 & São Paulo & Não & Não & Não & Não & Não & Sim & Não & 1750 & 1997 & Sim & Não & & Sim & Sim & & & Sim & $\mathbf{s i}$ & & & Sim & Sim & \\
\hline 661 & fev-06 & São Paulo & Não & Não & & Não & Não & Sim & Não & 1750 & 1997 & sim & Não & & sim & sim & & & Sim & Sim & & & Sim & Sim & \\
\hline 662 & mar-06 & São Paulo & Não & Não & Não & Não & Não & Sim & Não & 1750 & 1997 & Sim & Não & & Sim & Sim & & & Sim & Si & & & Sim & Sim & \\
\hline 663 & abr-06 & São Paulo & Não & Não & Não & Não & Não & sim & $\mathrm{N}$ & 17 & 1997 & Sim & Não & & sim & Sim & & & Sir & si & & & Sim & Sim & \\
\hline 664 & mai-06 & São Paulo & Não & Não & Não & Não & Não & sim & $\mathrm{N}$ & 17 & 1997 & Sim & Não & & sim & Sim & & & Sim & & & & im & Sim & \\
\hline 665 & jun-06: & $\begin{array}{l}\text { São Paulo } \\
\text { São Paun }\end{array}$ & Não & Não & Não & Não & Não & sim & $\mathrm{Ne}$ & 17 & 1997 & Sim & Não & & Sim & Sim & Sim & & Sim & $\mathrm{m}$ & & & im & Sim & \\
\hline 666 & $\begin{array}{l}\text { jun-06 } \\
\text { jul-06: }\end{array}$ & $\begin{array}{l}\text { Ião Paulo } \\
\text { São Paulo }\end{array}$ & $\begin{array}{l}\text { Não } \\
\text { Nãon }\end{array}$ & $\begin{array}{l}\text { Não } \\
\text { Não }\end{array}$ & $\begin{array}{l}\text { Não } \\
\text { Não }\end{array}$ & $\begin{array}{l}\text { Não } \\
\text { Não }\end{array}$ & $\begin{array}{l}\text { Não } \\
\text { Não }\end{array}$ & Sim & $\begin{array}{l}\text { Não } \\
\text { Não }\end{array}$ & $\begin{array}{l}1750 \\
1750\end{array}$ & $\begin{array}{l}1997 \\
1997\end{array}$ & Sim & $\begin{array}{l}\text { Não } \\
\text { Năo }\end{array}$ & & Sim & Sim & & & Sim & Sim & & & Sim & Sim & \\
\hline $\begin{array}{l}667 \\
668\end{array}$ & $\begin{array}{c}\text { Jall-06 } \\
\text { ago-06 }\end{array}$ & $\begin{array}{l}\text { Sao Paúlo } \\
\text { São Paulo }\end{array}$ & $\begin{array}{l}\text { Não } \\
\text { Não }\end{array}$ & $\begin{array}{l}\text { Nao } \\
\text { Não }\end{array}$ & $\begin{array}{l}\text { Nao } \\
\text { Não }\end{array}$ & $\begin{array}{l}\text { Não } \\
\text { Não }\end{array}$ & $\begin{array}{l}\text { Não } \\
\text { Não }\end{array}$ & $\begin{array}{c}\text { Sim } \\
\text { Sim }\end{array}$ & $\begin{array}{l}\text { Não } \\
\text { Não }\end{array}$ & $\begin{array}{l}1750 \\
1750\end{array}$ & $\begin{array}{l}199 / 1 \\
1997\end{array}$ & 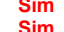 & $\begin{array}{l}\text { Não } \\
\text { Não }\end{array}$ & & $\mathrm{Sim}_{\mathrm{Sim}}$ & 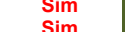 & & & Sim & Sim & & & 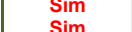 & $\begin{array}{c}\text { Sim } \\
\text { Sim }\end{array}$ & \\
\hline 669 & set-06 & São Paulo & Não & Não & Não & Não & Não & Sim & Não & 1750 & 1997 & Sim & Não & & Sim & Sim & & & Sim & Sim & & & Sim & Sim & \\
\hline 670 & out-06 & São Paulo & Não & Não & Não & Não & Não & Sim & Não & 1750 & 1997 & sim & Não & & Sim & Sim & & & Sim & Sim & & & Sim & sim & \\
\hline 671 & nov- & São Paulo & Não & Não & Não & Não & Não & Sim & $\mathrm{N}$ & 17 & 1997 & $\operatorname{Sin}$ & Não & & Sim & Sim & & & $\mathrm{Si}$ & & & & im & Sim & \\
\hline 672 & dez-06 & São Pa & Não & Não & Não & Não & Não & Sim & $\mathrm{N}$ & 17 & & Sim & Não & & & Sim & & & & & & & & Sim & \\
\hline 673 & jan-07 & São Paulo & Não & Não & Não & Não & Não & Sim & Não & 1750 & 1997 & Sim & Não & 2,4 & Sim & Sim & Não & Não & Sim & Sim & Sim & Sim & Sim & Sim & \\
\hline 674 & out-98 & Santo André & Sim & sim & Não & Não & Não & Não & Não & 350 & 1970 & Sim & Não & 6,5 & Não & Não & Sim & Não & Sim & Não & Sim & Não & & & \\
\hline 675 & nov-98 & Santo André & Nã & Não & Não & Não & Não & Sim & N & 350 & 1970 & Sim & Não & 6,50 & Não & Não & Sim & Não & Sim & Não & Sim & Não & Sim & & Sim \\
\hline 676 & mar-99 & Santo André & Não & Não & Não & Não & Não & Sim & Não & 350 & 1970 & Sim & Não & 6,50 & & & & & Sim & Sim & & & Sim & & Sim \\
\hline 677 & ago-00 00 & Santo Andre & Năo & Năo & Năo & Năo & Năo & Sim & Năo & 350 & 1970 & Sim & Nâo & 6,50 & & & & & Sim & Si & & & Sim & & Sim \\
\hline 678 & dez-00 & Santo André & Não & Não & Não & Não & Não & Sim & Não & $\begin{array}{l}350 \\
350\end{array}$ & 1970 & Sim & Não & 6,50 & & & & & Sim & Sim & & & Sim & & Sim \\
\hline $\begin{array}{l}680 \\
680\end{array}$ & dez-01 & Santo André & $\begin{array}{l}\text { Nao } \\
\text { Não }\end{array}$ & $\begin{array}{l}\text { Nao } \\
\text { Não }\end{array}$ & $\begin{array}{l}\text { Nao } \\
\text { Não }\end{array}$ & $\begin{array}{l}\text { Nao } \\
\text { Não }\end{array}$ & $\begin{array}{l}\text { Nao } \\
\text { Não }\end{array}$ & Sim & $\begin{array}{l}\text { Nao } \\
\text { Não }\end{array}$ & $\begin{array}{l}350 \\
350\end{array}$ & 1970 & Sim & $\begin{array}{l}\text { Nao } \\
\text { Não }\end{array}$ & $\begin{array}{l}6,50 \\
6,50\end{array}$ & & & & & $\mathrm{Sim}$ & Sim & & & Sim & & Sim \\
\hline & & & & & & & & & & & & & & & & & & & & & & & & & \\
\hline
\end{tabular}




\begin{tabular}{|c|c|c|c|c|c|c|c|c|c|c|c|c|c|c|c|c|c|c|c|c|c|c|c|c|c|}
\hline \multirow[b]{2}{*}{ ID } & \multirow[b]{2}{*}{$\mid \begin{array}{r}\text { Data } \\
\text { Registro }\end{array}$} & \multirow{2}{*}{$\begin{array}{l}\text { IDENTIFICAÇÃO } \\
\text { Cidade }\end{array}$} & \multicolumn{7}{|c|}{ GERENC CONAMA / CETESB } & \multicolumn{2}{|c|}{ DADOS DO POSTO } & \multicolumn{3}{|c|}{ Contexto geológico } & \multicolumn{2}{|c|}{ FASE VAPOR } & \multicolumn{2}{|c|}{ FASE RETIDA } & \multicolumn{2}{|c|}{ LNAPL } & \multicolumn{2}{|c|}{ Dissolv } & \multirow[b]{2}{*}{$\begin{array}{c}\text { Remediação } \\
?\end{array}$} & \multirow[b]{2}{*}{$\begin{array}{c}\text { Remediação } \\
\text { Z Nsatu? }\end{array}$} & \multirow[b]{2}{*}{$\begin{array}{l}\text { Remediaçã } \\
\text { Z Sat? }\end{array}$} \\
\hline & & & AvP & IC & ID & Artx & $\mathrm{PI}$ & REM & ME & $\begin{array}{l}\text { Área } \\
\mathrm{m} 2\end{array}$ & $\begin{array}{c}\text { Data } \\
\text { instala }\end{array}$ & Sed. & $\begin{array}{l}\text { Rocha } \\
\text { alterada }\end{array}$ & $\begin{array}{l}\text { ZN Sat } \\
(\mathrm{m})\end{array}$ & $\begin{array}{c}\text { Detectado } \\
?\end{array}$ & $\begin{array}{c}\text { Delimitado } \\
?\end{array}$ & $\begin{array}{c}\text { Detectado } \\
?\end{array}$ & $\begin{array}{c}\text { Delimitado } \\
?\end{array}$ & $\mid \begin{array}{c}\text { Detectado } \\
?\end{array}$ & Delimit & $\begin{array}{c}\text { Detectado } \\
?\end{array}$ & $\begin{array}{c}\text { Delimitada } \\
?\end{array}$ & & & \\
\hline 681 & & Santo André & Não & Não & Não & Não & Não & Sim & Não & 350 & 1970 & Sim & Não & 6,50 & & & & & Sim & Sim & & & Sim & & Sim \\
\hline 682 & dez-02 & Santo André & Não & Não & Não & Não & Não & sim & Não & 350 & 1970 & sim & Não & 6,50 & & & & & sim & Sim & & & Sim & & Sim \\
\hline 683 & ago-03 & Santo André & Não & Não & Não & Não & Não & Sim & Não & 350 & 1970 & Sim & Não & 6,50 & & & & & Sim & Sim & & & Sim & & Sim \\
\hline 684 & dez-03 & Santo André & Não & Não & Não & Não & Não & Sim & Não & 350 & 1970 & Sim & Não & 6,50 & & & & & Sim & Sim & & & Sim & & Sim \\
\hline 685 & $\begin{array}{r}\text { set-06 } \\
\text { abr-07 }\end{array}$ & $\begin{array}{l}\text { Santo André } \\
\text { Santo André }\end{array}$ & Não & $\begin{array}{l}\text { Não } \\
\text { Não }\end{array}$ & $\begin{array}{l}\text { Sim } \\
\text { Não }\end{array}$ & $\begin{array}{l}\text { Sim } \\
\text { Não }\end{array}$ & $\begin{array}{l}\text { Não } \\
\text { Não }\end{array}$ & $\begin{array}{l}\text { Não } \\
\text { Sim }\end{array}$ & $\begin{array}{l}\text { Não } \\
\text { Não }\end{array}$ & $\begin{array}{l}350 \\
350\end{array}$ & $\begin{array}{l}1970 \\
1970\end{array}$ & Sim & $\begin{array}{l}\text { Não } \\
\text { Não }\end{array}$ & $\begin{array}{l}6,50 \\
6,50\end{array}$ & Sim & Sim & Sim & Não & Sim & Sim & Sim & Sim & & & \\
\hline $\begin{array}{l}686 \\
687\end{array}$ & $\begin{array}{l}\text { abr-07 } \\
\text { jun-07 }\end{array}$ & $\begin{array}{l}\text { Santo André } \\
\text { Santo André }\end{array}$ & $\begin{array}{l}\text { Não } \\
\text { Não }\end{array}$ & $\begin{array}{l}\text { Não } \\
\text { Não }\end{array}$ & $\begin{array}{l}\text { Não } \\
\text { Não }\end{array}$ & $\begin{array}{l}\text { Não } \\
\text { Não }\end{array}$ & $\begin{array}{l}\text { Naò } \\
\text { Não }\end{array}$ & $\begin{array}{l}\text { Sim } \\
\text { Sim }\end{array}$ & $\begin{array}{l}\text { Não } \\
\text { Não }\end{array}$ & $\begin{array}{l}\begin{array}{r}350 \\
350\end{array} \\
350\end{array}$ & $\begin{array}{l}1970 \\
1970\end{array}$ & $\begin{array}{l}\text { Sim } \\
\text { Sim }\end{array}$ & $\begin{array}{l}\text { Não } \\
\text { Não }\end{array}$ & $\begin{array}{l}6,50 \\
6,50\end{array}$ & & & & & & & $\operatorname{sim}$ & Sim & Sim & Sim & Sim \\
\hline 688 & ago-07 & $\begin{array}{l}\text { Santo Anaree } \\
\text { Santo André }\end{array}$ & Não & Não & Não & Não & Não & Sim & $\begin{array}{l}\text { Nao } \\
\text { Não }\end{array}$ & 350 & 1970 & Sim & $\begin{array}{l}\text { Nao } \\
\text { Não }\end{array}$ & $\begin{array}{l}6,50 \\
6,50\end{array}$ & Sim & Sim & & & sim & Sim & $\begin{array}{l}\text { Sim } \\
\text { Sim }\end{array}$ & $\begin{array}{l}\text { Sim } \\
\text { Sim }\end{array}$ & Sim & & Sim \\
\hline 689 & set- 07 & Santo André & Não & Não & Não & Não & Não & Sim & Não & 350 & 1970 & Sim & Não & $\begin{array}{l}0,50 \\
6,50\end{array}$ & Sim & sim & & & sim & Sim & & & $\mathrm{SIm}$ & & $\operatorname{sim}$ \\
\hline 690 & out -07 & Santo André & Não & Não & Não & Não & Não & Sim & Não & 350 & 1970 & Sim & Não & 6,50 & Sim & Sim & & & Sim & Sim & & & & & sim \\
\hline 691 & nov-07 & Santo André & Não & Não & Não & Não & Não & Sim & Não & 350 & 1970 & Sim & Năo & 6,50 & Sim & Sim & & & Sim & Sim & & & & & $\operatorname{sim}$ \\
\hline 692 & dez-07 & Santo André & Não & Não & Não & Não & Não & Sim & Não & 350 & 1970 & sim & Não & 6,50 & sim & $\mathrm{Sim}$ & & & Sim & Sim & & & & & sim \\
\hline 693 & jan-08 & Santo André & Não & Não & Não & Não & Não & Sim & Não & 350 & 1970 & Sim & Não & 6,50 & Não & Não & & & Não & Não & & & Sim & & Sim \\
\hline 694 & fev-08 & Santo André & Não & Não & Não & Não & Não & Sim & Não & 350 & 1970 & Sim & Não & 6,50 & sim & Sim & & & Sim & Sim & & & Sim & & Sim \\
\hline 695 & mar-08 & Santo André & Não & Não & Não & Não & Não & Sim & Não & 350 & 1970 & Sim & Não & 6,50 & sim & Sim & & & Não & Não & & & Sim & & Sim \\
\hline 696 & abr-08 & Santo André & Não & Não & Não & Não & Não & Sim & Não & 350 & 1970 & Sim & Não & 6,50 & Sim & Sim & & & Não & Não & & & Sim & & Sim \\
\hline 697 & mai-08 & Santo André & Não & Não & Não & Não & Não & Sim & Não & 350 & 1970 & Sim & Não & 6,50 & Sim & Sim & & & Não & Não & & & Sim & & Sim \\
\hline 698 & jun-08 & Santo André & & & Sim & Sim & Não & Não & Não & 350 & 1970 & Sim & Não & 6,50 & Sim & Sim & Sim & Não & Não & Não & Sim & Sim & & & sim \\
\hline 699 & jul-08 & Santo André & Não & Não & Não & Não & Não & Sim & Não & 350 & 1970 & sim & Não & 6,50 & Sim & Sim & & & Não & Não & & & Sim & & Sim \\
\hline 700 & ago-08 & Santo André & Não & Não & Não & Não & Não & Sim & Não & 350 & 1970 & Sim & Não & 6,50 & Nâo & Nầ & & & Não & Não & & & sim & & Sim \\
\hline 701 & set-08 & Santo André & Não & Não & Não & Não & Não & Sim & Não & 350 & 1970 & Sim & Não & 6,50 & Sim & sim & & & Não & Não & & & Sim & & Sim \\
\hline 702 & out-08 & Santo André & Não & Não & Não & Não & Não & Sim & Não & 350 & 1970 & Sim & Não & 6,50 & Sim & Sim & & & Não & Não & & & Sim & & Sim \\
\hline 703 & nov-08 & Santo André & Não & Não & Não & Não & Não & Sim & Não & 350 & 1970 & Sim & Não & 6,50 & Sim & Sim & & & Não & Não & & & Sim & & Sim \\
\hline 704 & $\begin{array}{c}\text { dez-08 } \\
\text { an }-09\end{array}$ & Santo André & Não & Não & Não & Não & Não & Sim & Não & $\begin{array}{l}350 \\
350\end{array}$ & 1970 & sim & Não & 6,50 & Sim & Sim & & & Não & Não & & & Sim & & Sim \\
\hline 705 & jan-09 & $\begin{array}{l}\text { Santo André } \\
\text { Santo André }\end{array}$ & Não & Não & Não & Não & Não & Sim & Não & $\begin{array}{l}350 \\
350\end{array}$ & 1970 & Sim & Não & $\begin{array}{l}6,50 \\
650\end{array}$ & Sim & Sim & & & Não & Não & & & & & Sim \\
\hline $\begin{array}{l}706 \\
707\end{array}$ & $\begin{array}{r}\text { fev-09 } \\
\text { mar-09 }\end{array}$ & $\begin{array}{l}\text { Santo Andre } \\
\text { Santo André }\end{array}$ & $\begin{array}{l}\text { Não } \\
\text { Não }\end{array}$ & $\begin{array}{l}\text { Não } \\
\text { Não }\end{array}$ & $\begin{array}{l}\text { Não } \\
\text { Não }\end{array}$ & $\begin{array}{l}\text { Não } \\
\text { Não }\end{array}$ & $\begin{array}{l}\text { Não } \\
\text { Não }\end{array}$ & Sim & $\begin{array}{l}\text { Não } \\
\text { Não }\end{array}$ & $\begin{array}{l}\begin{array}{l}350 \\
350\end{array} \\
350\end{array}$ & $\begin{array}{l}1970 \\
1970\end{array}$ & $\begin{array}{l}\text { Sim } \\
\text { sim }\end{array}$ & $\begin{array}{l}\text { Não } \\
\text { Năo }\end{array}$ & $\begin{array}{l}6,50 \\
650\end{array}$ & $\begin{array}{l}\text { Sim } \\
\text { sim }\end{array}$ & Sim & & & $\begin{array}{l}\text { Não } \\
\text { Não }\end{array}$ & $\begin{array}{l}\text { Não } \\
\text { Não }\end{array}$ & & & & & Sim \\
\hline 708 & abr-09 & Santo André & Não & Não & Não & Não & $\begin{array}{l}\text { Nà } \\
\text { Não }\end{array}$ & Sim & Não & 350 & 1970 & Sim & $\begin{array}{l}\text { Não } \\
\text { Nân }\end{array}$ & $\begin{array}{l}6,50 \\
6,50\end{array}$ & Sim & Sim & & & $\begin{array}{l}\text { Nao } \\
\text { Não }\end{array}$ & $\begin{array}{l}\text { Nao } \\
\text { Não }\end{array}$ & & & & & $\begin{array}{l}\text { Sim } \\
\text { Sim }\end{array}$ \\
\hline 709 & jun-09 & Santo André & Não & Não & Não & Não & Não & sim & Não & 350 & 1970 & Sim & Não & 6,50 & Sim & Sim & Não & Não & Não & Não & Sim & Sim & & & Sim \\
\hline 710 & jul-09 & Santo André & Não & Não & Não & Não & Não & Sim & & 350 & 1970 & Sim & Não & 6.5 & & & & & Năo & $N$ & Sim & Sim & & & sim \\
\hline 711 & out-09 & Santo André & Não & Não & Não & Não & Não & Sim & Não & 350 & 1970 & Sim & Não & 6,50 & sim & sim & & & Não & Não & & & Sim & & Sim \\
\hline 712 & nov-09 & Santo André & Não & Não & Não & Não & Não & Sim & Não & 350 & 1970 & Sim & Não & 6,50 & Sim & Sim & & & Não & Não & & & Sim & Sim & Sim \\
\hline 713 & jan-10 & Santo André & Não & Não & Não & Não & Não & sim & Não & 350 & 1970 & Sim & Não & 6,5 & sim & Sim & & & Não & Não & & & Sim & sim & Sim \\
\hline 714 & mar-10 & Santo André & Não & Não & Não & Não & Não & Sim & Não & 350 & & Sim & Não & 6,5 & sim & Sim & Não & Não & Não & Não & Sim & Sim & sim & Sim & Sim \\
\hline 715 & & & Nã & Não & Não & Não & Não & Sim & Não & 35 & & Sim & Nã & 6,5 & Sim & Sim & & Não & Não & Não & Sim & Sim & im & im & Sim \\
\hline 716 & jun-10 & Santo André & Não & Não & Não & Não & Não & Sim & $\mathrm{N}$ & 35 & 1970 & Sim & Não & 6,5 & Não & Não & Não & Não & Não & Não & & & Sim & im & Sim \\
\hline 717 & jul-10 & Santo André & Não & Não & Não & Não & Não & Sim & Não & $\begin{array}{l}350 \\
350\end{array}$ & 1970 & Sim & Não & 6,50 & Não & Não & Não & Não & Não & Não & & & Sim & Sim & Sim \\
\hline 718 & set-10 & $\begin{array}{l}\text { Santo André } \\
\text { Santo André }\end{array}$ & Não & Não & Não & Não & Não & Sim & Não & $\begin{array}{l}350 \\
350\end{array}$ & 1970 & $\operatorname{sim}$ & Não & 6,50 & Não & Não & Não & Não & Não & Não & & & sim & Sim & Sim \\
\hline 719 & $\begin{array}{l}\text { out-10 } \\
\text { dez-10 }\end{array}$ & $\begin{array}{l}\text { Santo Andre } \\
\text { Santo André }\end{array}$ & $\begin{array}{l}\text { Não } \\
\text { Não }\end{array}$ & $\begin{array}{l}\text { Não } \\
\text { Não }\end{array}$ & $\begin{array}{l}\text { Não } \\
\text { Não }\end{array}$ & $\begin{array}{l}\text { Não } \\
\text { Não }\end{array}$ & $\begin{array}{l}\text { Não } \\
\text { Não }\end{array}$ & $\begin{array}{l}\text { Sim } \\
\text { Sim }\end{array}$ & $\begin{array}{l}\text { Não } \\
\text { Não }\end{array}$ & $\begin{array}{l}350 \\
350\end{array}$ & $\begin{array}{l}1970 \\
1970\end{array}$ & $\begin{array}{l}\text { Sim } \\
\text { sim }\end{array}$ & $\begin{array}{l}\text { Não } \\
\text { Nẵo }\end{array}$ & $\begin{array}{l}6,50 \\
6,50\end{array}$ & $\begin{array}{l}\text { Não } \\
\text { Não }\end{array}$ & $\begin{array}{l}\text { Nẫo } \\
\text { Năo }\end{array}$ & $\begin{array}{l}\text { Não } \\
\text { Não }\end{array}$ & $\begin{array}{l}\text { Não } \\
\text { Não }\end{array}$ & $\begin{array}{l}\begin{array}{l}\text { Não } \\
\text { Não }\end{array} \\
\text { lat }\end{array}$ & $\begin{array}{l}\text { Não } \\
\text { Não }\end{array}$ & & & Sim & sim & Sim \\
\hline 720 & abr-11 & Santo André & $\begin{array}{l}\text { Não } \\
\text { Não }\end{array}$ & $\begin{array}{l}\text { Năo } \\
\text { Não }\end{array}$ & $\begin{array}{l}\text { Năo } \\
\text { Não }\end{array}$ & $\begin{array}{l}\text { Nao } \\
\text { Não }\end{array}$ & $\begin{array}{l}\text { Năo } \\
\text { Não }\end{array}$ & Sim & $\begin{array}{l}\text { Nao } \\
\text { Não }\end{array}$ & 350 & 1970 & Sim & $\begin{array}{l}\text { Não } \\
\text { Não }\end{array}$ & $\begin{array}{l}0,50 \\
6,50\end{array}$ & $\begin{array}{l}\text { Nao } \\
\text { Não }\end{array}$ & $\begin{array}{l}\text { Nao } \\
\text { Não }\end{array}$ & Nao & $\begin{array}{l}\text { Nao } \\
\text { Não }\end{array}$ & $\begin{array}{l}\text { Nao } \\
\text { Não }\end{array}$ & $\begin{array}{l}\text { Nao } \\
\text { Não }\end{array}$ & sim & sim & Sim & Sim & Sim \\
\hline 722 & jun-11 & Santo André & Não & Não & Não & Não & Não & Năo & $\mathrm{Si}$ & 350 & 1970 & Sim & Não & 6,50 & Não & Não & & & Não & Não & Sim & Sim & & & \\
\hline 723 & jul-11 & Santo André & Não & Năo & Não & Não & Não & Não & Sii & 350 & 1970 & $\mathrm{sin}_{\mathrm{in}}$ & Não & 6,50 & Não & Não & & & Năo & Não & & Sim & & & \\
\hline 724 & ago-11 & Santo André & Não & Não & Não & Não & Não & Não & Sim & 350 & 1970 & Sim & Não & 6,50 & Não & Não & & & Não & Não & Sim & Sim & & & \\
\hline 725 & mai-12 & Santo Andrè & Não & Não & Não & Não & Não & Não & Sim & 350 & 1970 & Sim & Não & 6,50 & & & & & sim & sim & Sim & Sim & & & \\
\hline
\end{tabular}

